\title{
A Review of Tribological Sinks in Six Major Industries
}

September 1985

Prepared for the U.S. Department of Energy under Contract DE-AC06-76RLO 1830

Pacific Northwest Laboratory Operated for the U.S. Department of Energy by Battelle Memorial Institute 


\title{
DISCLAIMER
}

This report was prepared as an account of work sponsored by an agency of the United States Government. Neither the United States Government nor any agency thereof, nor any of their employees, makes any warranty, express or implied, or assumes any legal liability or responsibility for the accuracy, completeness, or usefulness of any information, apparatus, product, or process disclosed, or represents that its use would not infringe privately owned rights. Reference herein to any specific commercial product, process, or service by trade name, trademark, manufacturer, or otherwise, does not necessarily constitute or imply its endorsement, recommendation, or favoring by the United States Government or any agency thereof. The views and opinions of authors expressed herein do not necessarily state or reflect those of the United States Government or any agency thereof.

\author{
PACIFIC NORTHWEST LABORATORY \\ operated by \\ BATTELLE \\ for the \\ UNITED STATES DEPARTMENT OF ENERGY \\ under Contract DE-AC06-76RLO 1830
}

\begin{tabular}{|c|c|}
\hline \multicolumn{2}{|c|}{ Printed in the United States of America } \\
\hline \multicolumn{2}{|c|}{ Available from } \\
\hline \multirow{2}{*}{\multicolumn{2}{|c|}{$\begin{array}{l}\text { National Technical Information Service } \\
\text { United States Department of Commerce }\end{array}$}} \\
\hline & \\
\hline \multicolumn{2}{|c|}{ S285 Port Royal Road } \\
\hline \multicolumn{2}{|c|}{ Springfield, Virginia 22161} \\
\hline \multirow{2}{*}{\multicolumn{2}{|c|}{$\begin{array}{l}\text { NTIS Price Codes } \\
\text { Microfiche } A 01\end{array}$}} \\
\hline & \\
\hline \multicolumn{2}{|c|}{ Printed Copy } \\
\hline & \\
\hline Pages & Codes \\
\hline $001-025$ & A02 \\
\hline $026-050$ & $\wedge 03$ \\
\hline $051-075$ & A04 \\
\hline $076-100$ & AOS \\
\hline $101-125$ & 106 \\
\hline $126-150$ & $\wedge 07$ \\
\hline $151-175$ & $A 00$ \\
\hline $176-200$ & A09 \\
\hline $201-225$ & A010 \\
\hline 226.250 & A011 \\
\hline $251-275$ & $\wedge 012$ \\
\hline $276-300$ & $\wedge 013$ \\
\hline
\end{tabular}


PNL -5535

A REVIEW OF TRIBOLOGICAL SINKS

IN SIX MAJOR INDIJSTRIES
C. H. Imhoff
D. R. Brown
f. J. Hane
R. A. Hutchinson

R. Erickson (a)

T. Merriman (a)

T. Gruber a)

S. Barber (a)

T. M. Levinson

DOE/ECUT Progran Manager

September 1985

Prepared for

Energy Conversion and Utilization

Technologies Division

Office of Energy Systems Research

Conservation and Renewable Energy

U.S. Department of Energy

under Contract DE-AC06-76RLO 1830

Pacific Northwest Laboratory

Richland, Washington 99352

(a) Battelle-Columbus Laboratories, Columbus, Ohio 

Experts estimate that in 1978 over four quadrillion Btu of energy were lost in the United States because of simple friction and wear--enough energy to supply New York City for an entire year. This translates to a $\$ 20$ billion loss, based on oil prices of about $\$ 30$ per barrel. (a) Because of the enormity of this energy loss, the Energy Conversion and Utilization Technologies (ECUT) Program in the U.S. Department of Energy (DOE) initiated a program in 1983 to study tribology--the science of friction and wear--to learn more about the causes of these energy losses (or tribologica) "sinks") and how to reduce them.

The ECUT Program itself was started in 1980 to encourage research to improve energy conversion and utilization efficiency. The enormous energy loss in tribological sinks has been targeted by the ECUT program as having significant potential for energy conservation. One goal of the ECUT Tribology Program is to reduce these energy losses by developing improved lubricants and more durable materials.

To support initial Tribology Program planning, ECUT conducted six surveys to gather three types of information about the current tribology problem in the U.S.:

1. The identification of typical industrial sinks

2. A survey of current U.S. Government tribology projects

3. The identification of tribology R\&D needs based on industry perceptions.

The six ECUT-sponsored surveys are listed in Table ES.1. Each survey is being published as a separate volume with its own summary. This executive summary, which also appears in each of the six volumes, presents an overview of results from the six surveys and their implications for energy conservation. The results of these six surveys and their implications for energy conservation are presented in this summary. These results will be used to support further research planning for the ECUT Tribology Program.
TABLE ES.1. ECUT Surveys Reviewed in this Sumary

1. A Review of Tribological Sinks in Six Major Industries. Imhaff, et al. PNL-5535, Pacific Northwest. Laboratory, Richland, Washington.

2. Reduction in Tribological Eneray cosses in the Transportation and Electric Utilities Sectors. Pinkus and Wilcock, Mechanical Technology Incorporated. PNL-5536, Pacific Northwest Laboratory, Richland, Washington.

3. Identification of Tribological Research and Development Needs for Lubrication of Advanced heat Engines. Fehrenbacher, Technology Assessment and Transfer, Incorporated. PNL-5537, Pacific Northwest Laboratory, Richland, Washington.

4. Energy Conservation Potential of Surface Modification Technologies. Le Khac, DHR, Inc. PNL-5538, Pacific Northwest Laboratory, Richland, Washington.

5. Assessment of Government Tribology Programs. Peterson, Hear Scíences Corporation. PNL -5539 , Pacific Northwest Laboratory, Richland, Washington.

6. Assessment of Industrial Attitudes Toward Generic Research Needs in Tribology. Sibley and 2lotnick, Tribology Consultants Incorporated. PNL -5540 , Pacific Northwest Laboratory, Richiand, Washington.

IDENTIFYING TYPICAL TRIBOLOGICAL SINKS ARD MECHANISINS

ECUT's first step in collecting information about tribology was to identify significant tribological sinks and mechanisms. This information was needed to focus research on key technological problems. Because the industry, transportation, and utilities sectors account for most of the

(a) Calculations in this summary are based on a $\$ 30$ figure. 
energy consumed in the U.S., ECUT concentrated first on the tribological energy sinks and mechanisms found in these three sectors. The report by Imhoff, et al., describes the most important tribological sinks typically found in industry, and the report by Pinkus and Wilcock describes tribological energy losses in the transportation and utilities sectors. Two specific studies assessed tribological problems in the metalworking industry and in the advanced diesel engine.

To identify areas in which tribology has a significant impact, the authors examined the energy consumed, the fuels used, and the primary products and processes found in the transportation, industrial, and utilities sectors. Once energy losses were 1 dentified, their magnitude was estimated. The estimates include both friction losses (direct losses) and material wear losses (indirect losses). The authors also estimated the energy savings potential in each sector and recommended some specific R\&D programs to help achieve these energy savings.

\section{The Industrial Sector}

Tribological energy losses are pervasive throughout industry. Because reviewing all industries and industrial processes in detail would be impossible, the Imhoff, et al. survey, instead chose six representat ive industries (Mining, Agriculture, Primary Metals, Chemicals/Refining, Pulp and Paper, and Food Processing) that appeared to have

the most significant tribological sinks and energy losses. These industries were selected because of their 1) major, nonthermal energy streams (such as machine drives); 2) high material wear rates and friction; 3) significant material transportation/alteration processes; and 4) total energy use.

The study identified important tribological sinks in each selected industry, based on both friction and material wear energy losses and on the tribological mechanisms and materials involved. Figure ES.1 and Table ES.2 show the key results for each of the six industries.

The first conciusion from this study confi med earlier clatims that losses from material wear are greater than energy losses from friction; the wear losses in five of the industries were found to be more tpap twice as large as the friction losses. (a) The study also concluded that reducing material wear rates to improve equipment life

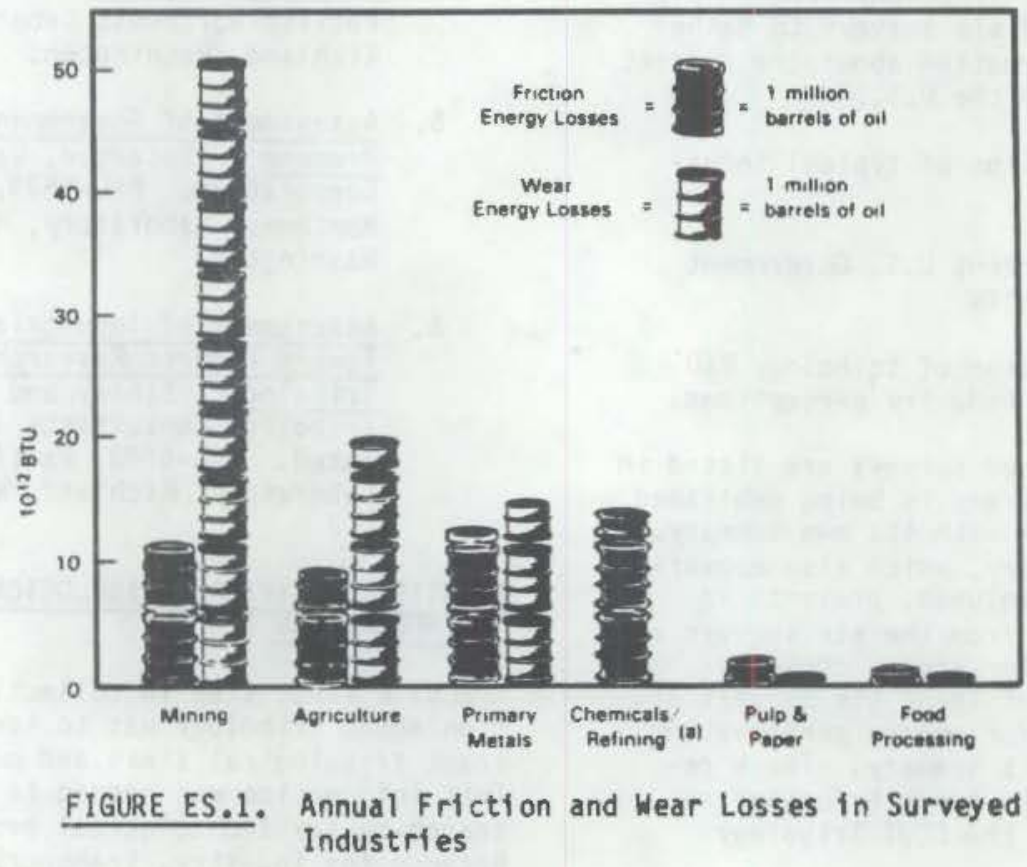

(a) These five industries had estimates of both friction and material wear losses; the sixth, Chemicals/Refining, did not have estimates of wear losses. 
TABLE ES.2. Primary Mechanisms in Friction Energy Losses and Principal Materials Involved in Wear Energy Losses

\begin{tabular}{|c|c|c|}
\hline Industry & Mechant sms & Materials \\
\hline Mining & $\begin{array}{l}\text { 3-body Abrasion } \\
\text { Friction }\end{array}$ & $\begin{array}{l}\text { Iron, Steel \& alloys, } \\
\text { Alumi num, Rubber }\end{array}$ \\
\hline Agriculture & $\begin{array}{l}\text { 3-body Abrasion } \\
\text { Friction }\end{array}$ & Steel, Rubber, Lubricants \\
\hline Primary Metals & $\begin{array}{l}\text { Hot Rolling } \\
\text { Inefflciencies }\end{array}$ & Steel alloys \\
\hline Chemicals/Refining & $\begin{array}{l}\text { Friction, Erosion } \\
\text { Abrasion }\end{array}$ & Not studied \\
\hline Puip \& Paper & Friction & $\begin{array}{l}\text { Steel \& alloys, Chromi um- } \\
\text { Molybdenum ailoys } \\
\text { Grinding stones }\end{array}$ \\
\hline Food Processing & Erosion, Abrasion & Steel \& alloys \\
\hline
\end{tabular}

and reliability would aiso significantly improve industrial productivity. The industry representatives interviewed strongly emphasized the positive impacts that tribological research could have on operational productivity.

\section{Tribology in the Metalworking Industry}

In addition to the general review of tribological sinks in industry, ECUT sponsored a more specific study of tribology in the metalworking industry by Le Khac at DHR, Inc. The study estimated the energy conservation potential of using advanced surface modification technologies in this industry. These surface modification technologies are thermal, chemical, or mechanical creatments that reduce friction and wear at a material's surface without changing its bulk properties. The advanced surface modification technologi es considered were ion implantation, laser surface hardening, electron beam surface hardenting, and wearresistant coating deposition. The author studied 70 percent of the metal-forming and metal-cutting machines used in the United States (except those associated with primary metals processing), identified tribological mechanisms, and estimated friction and wear energy losses. Potential energy savings from using surface-modified tools were also estimated.

The metal-forming machines studied were punches, presses and forges, and the metalcutting machines studied were turning, drilling, milling, broaching, and sawing machines. Models were developed to estimate friction and wear energy losses and potential savings. The friction losses were estimated by adding friction losses at the motor drive system and at the tool-workpiece interface. Estimates of energy consumption were based on standard operating conditions (known friction coefficients, total working time, etc.) The indirect losses from wear were estimated based on the replacement costs of all metalworking tools used and discarded in one year.

Based on actual experimental or production data, the author estimated that the friction losses in all U.S. getalworking machines amount to $20.2 \times 10^{12}$ Btu per year, or $\$ 104.5$ million. Of this energy loss, $1.8 \times$ 1012 Btu per year, or $9 \%$, could be saved using surface modification technologies to reduce friction. The wear loss was
estimated to be $7.7 \times 10^{12}$ Btu per year. (a) Possible energy savings using surface modification technologies to reduce wear could conserve $5.5 \times 10^{12}$ Btu per year, or $71 \%$.

Finally, the author estimated that tribological energy losses in all U, working machines total $27.9 \times 10^{12} \mathrm{Btu}$, equitvalent to $4.8 \mathrm{milli}$ on barrels of ofl or $\$ 144$ mllion annually. More than a quarter of this loss could be saved using surface modification technologies to reduce friction and wear. These results are shown in Figure ES.2.

(a) Using 19.2 million Btu per ton as the embodied energy in steels. 


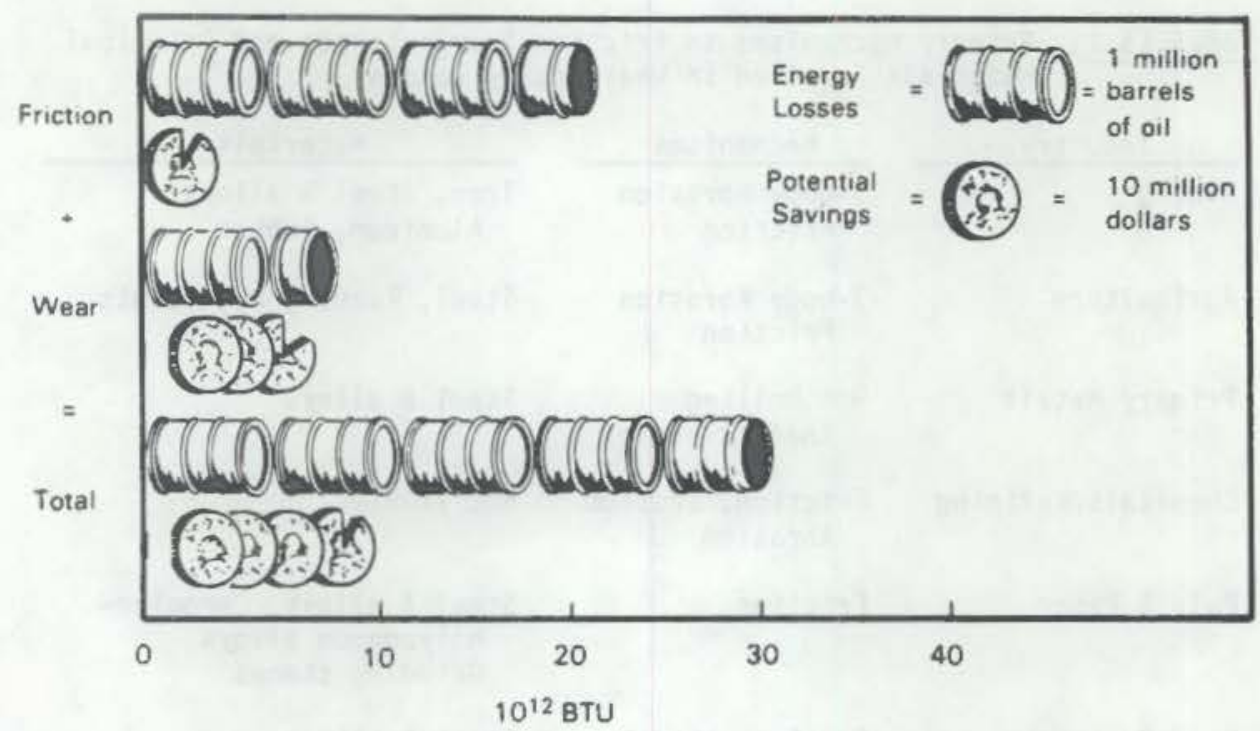

FIGURE ES.2. Annual Friction and Wear Energy Losses in the Metalworking Industry, and Potential Savings from Surface Modification Technologies

\section{The Transportation Sector}

The transportation sector is important both in terms of its energy consumption $126 \%$ of tota] U.S. annual energy consumption, or $19 \times 10^{15} \mathrm{Btu}$, equivalent to $\$ 98$ billion), and because of the high level of tribological losses. The Pinkus and Wilcock study primarily focused on the highway fleets (passenger cars, buses and trucks), which consume $77 \%$ of the total energy used in the transportation sector. The survey primarily addressed the conventional otto cycle engine. However, other concepts were also considered, such as the adiabatic diesel, the gas turbine, and the Stirling engine; in addition, the Fehrenbacher report evaluated tribological activity in advanced diesel engi nes.

Figure ES. 3 shows the principal automotive tribological sinks and the estimated energy savings. The principal automotive energy sinks are caused by the mechanical inefficiency of the engines and drive trains; most of the energy losses are due to friction.

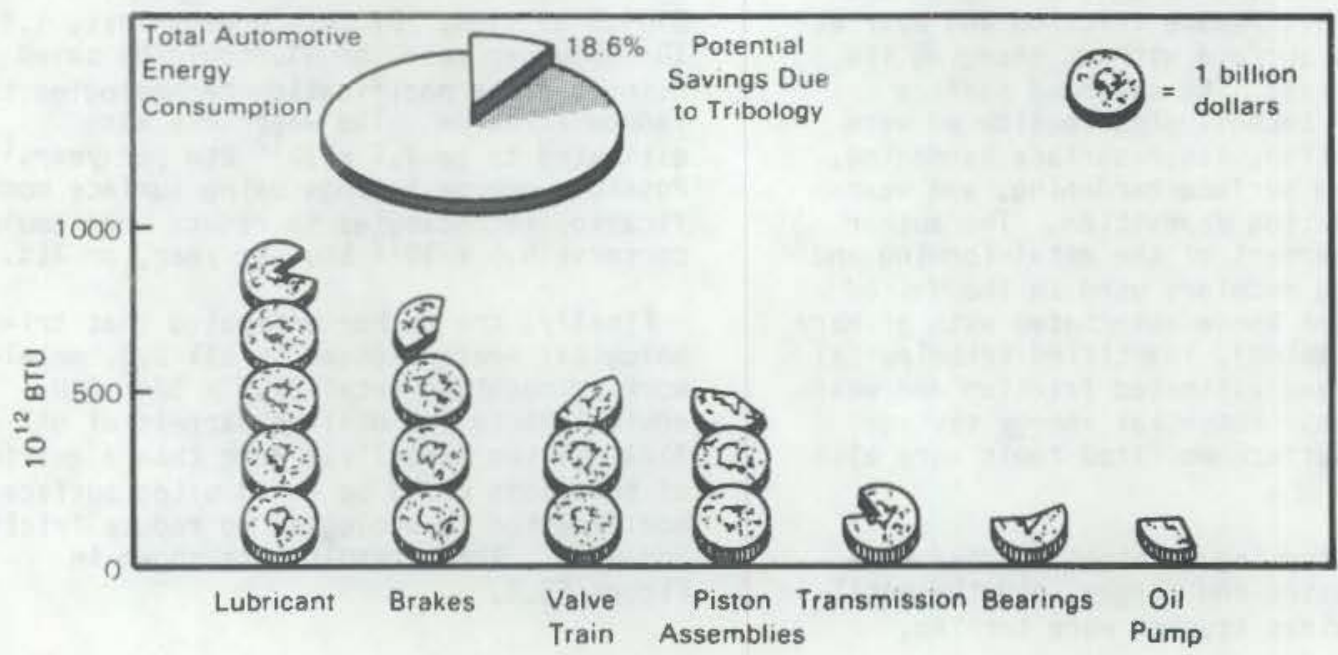

FIGURE ES.3. Potential Energy Savings Per Year for the Conventional Engine (Based on highway fleet size in 1976) 
The survey by Pinkus and Wilcock revealed several tribological areas of particular concern for conventional engines, such as the piston ring assembly and the long-range effect of low-viscosity oil on engine wear. As shown in Figure ES.3, tribological improvements could save $18.6 \%$ of the total annual energy consumed by automobiles, or $\$ 14.3$ billion.

Research on conventional engines often applies to unconventional engines as well. Except for the adiabatic diesel, the enerqy savings possible from tribological improvements to unconventional engines are less significant than those of the conventional otto cycle engine. The major problems in unconventional engines are related to hightemperature tribological problems. Introducing adiabatic and mi nimum friction engines into the bus and truck fleets of the U.S. could save up to $2.9 \%$ of total U.S. energy consumption.

This survey also revealed the difficulties with devising adequate performance tests to quantify energy losses and evaluate new designs and products. Laboratory tests that accurately reflect real-world conditions are badly needed. The ability to test entire systems is vital, since tribological energy losses are often caused by complex interactions between all the components of a system.

\section{Advanced Diesel Engines}

Because of the great potential for energy savings, the ECUT study by Fehrenbacher examined the lubrication of advanced diesel engines in detail. The efficiency of these engines could be improved by about 10\%; however, higher operating temperatures $\left(1000^{\circ} \mathrm{F}\right.$ and higher in the upper cylinder area) are required to reach this greater efficiency. As a result, the primary development challenge for these engines concerns friction, wear, and lubrication of the upper cylinder region. In fact, tribological advancements in these areas are essential if diesel engine performance and durability goals are to be reached. This study assessed these vital tribological concerns in both current and future technologies and recommended tribology R\&D topics for further advanced engi ne development.

Both the mechanical design of the upper cylinder and the chemical effects of lubricants and fuel determine the friction and wear characteristics of the upper cylinder region. These two factors interact in a complex and sometimes synergistic manner. The geometry of the piston, piston ring, and cylinder di rectly affect the rate and nature of deposit formation, oil consumption, and friction. Efforts have been made to optimize the upper cylinder geometry in current diesel engine technology; this -111 also be a critical area in future developments. However, problems with upper cylinder deposits, bore polishing, and oil consumption still exist. This study indicates that these problems are caused by the chemical interactions between upper cylinder materials, oil degradation products, and fuel combustion by-products. Therefore, lubricants, oil degradation rates, and mechanisms will continue to be important research areas.

Although a great deal of research has been conducted on liquid lubricants, in most cases the lubricants have been tested whout considering the tribological factors specific to the upper cylinder. Since the lubricants interact with the materials and environment of the upper cyilinder, they must be developed and tested under similar conditions.

The ECUT study also pointed out that future advanced engine concepts will require ceramic upper cylinder materials able to withstand the higher operating temperatures. New lubricants wlll have to be developed, and solid lubricants are likely to play a major role. A major research effort will be needed in this area; again, the research must be conducted on a total system basis to be most effective.

The study concluded that many problems with current diesel engines will continue to exist in advanced diesel engines. Tribological problems in the upper cylinder region will be most critical in terms of engine performance and wear. Lubricant R\&D is still a major research area in current technology, but total system materlals and design considerations should be emphasized. Advanced diesel concepts $=111$ requil re new design approaches, but the tribology of the upper cylinder region will still be critical and may even be the $11 \mathrm{mit}$ ting factor in achieving higher engine efficiencies. Extensive materials R\&D w11 be requi red for advanced designs as well, especially in ceramics, ceramic composites and solid lubricants.

\section{The Utilities Sector}

The utilities sector was also revi ewed for significant tribology sinks. This sector accounts for roughly $28 \%$ of total U.S. energy consumption. ECUT's review revealed that tribological improvements in efficiency and reliability could save $2.3 \%$ of the total energy annually consumed by utilities, or about $\$ 2.5$ billion. As in the transportation sector, efficiency is a major factor. 
However, reliability (especially in generating units) is just as important for energy conservation.

The data used in these studies were primarily for the utilities' power plants. The average power plant operates at an efficiency (output energy/input energy) between 30 and $40 \%$. Mechanical losses account for $17-26 \%$ of the total energy used. Reliability problems that lead to generator shutdown require using standby equipment, which generally has less efficlent fuel consumption. This causes losses both in terms of fuel economy, and revenue and labor costs. Tribological problems are estimated to cause as much as $5 \%$ of the reliability problems that require shutdown. Furthermore, tribology-caused shutdowns increase with the size of the power generating unit.

The ECUT survey found several tribological areas with significant energy savings potential, including gas path leakage, seals, and bearings on both the main turbine generator and on the various accessories. Different forms of bearing and lubricant problems (contaminated oils, pump problems, etc.) and vibrations are the leading causes of the plant shutdowns.

Figure ES.4 summarizes potential savings from improving tribological problems in the electric utilities. For accessories, the major concern is sealing problems with feedwater pumps. Friction and wear are implicated in much of the seal and bearing losses. The major problems identified in this study will requite research on lubrication theory and advanced materials and coatings developments.

\section{CURRENT U.S. GOVERNMENT PROGRAMS}

The second part of ECUT's information collecting efforts involved identffying tribology R\&D currently being sponsored or conducted by the U.S. Government. This information was needed to avoid duplicating existing research and to locate those areas that need more research support. The Peterson study identified 215 current projects sponsored by 21 different government organizations. The study classified these projects by subject, objective, energy conservation relevance, type of research, phenomena and variables being investigated, materials, and applications. The principal government sponsors include the Department of Defense (DOD), the National Aeronautics and Space Administration (NASA), National Science Foundation (NSF), National Bureau of Standards (NBS), and DOE.

The study located these tribology projects intifilly by using information from literature searches. Data bases used included the Smithsonian Science Information Exchange, the Defense Technical Information Center's Research and Technology Work Unit Information System, and the Materials Science Abstracts of the National Technical Information Service (NTIS). The study located a

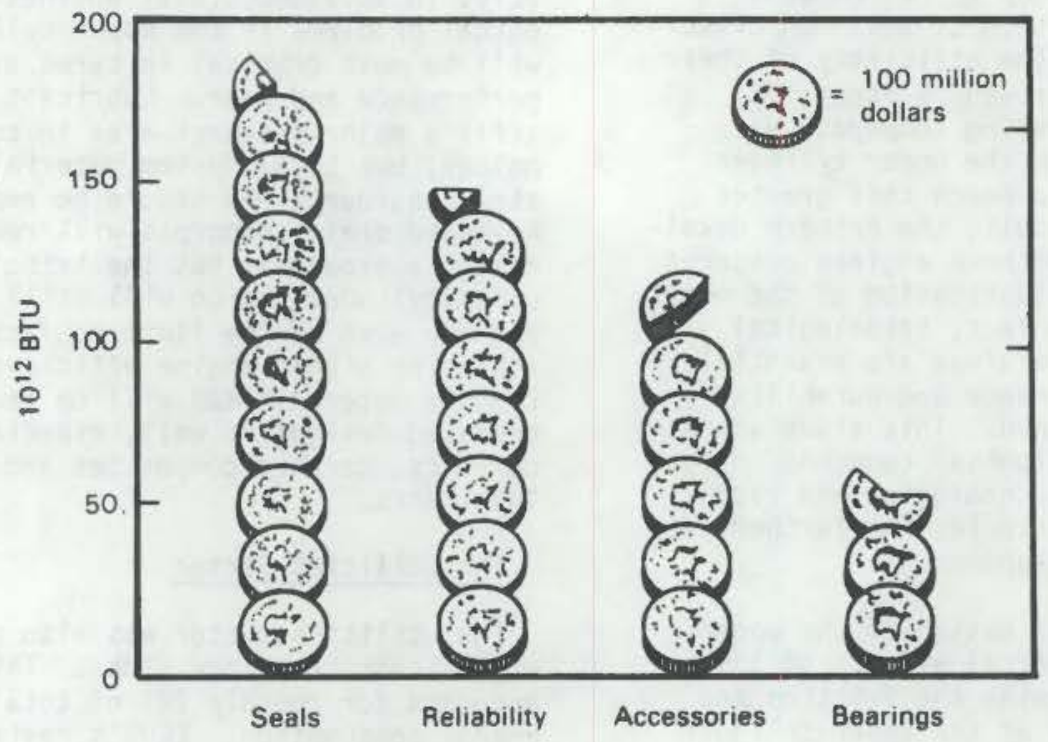

FIGURE ES.4. Potential Energy Savings for the Utilities (Based on estimates of installed capacity in 1983 and on an energy cost of $\$ 30$ per barrel.) 
total of 640 government-sponsored projects covering the fiscal years 1978-1983. These organizations were then contacted by mafl, followed by visits and/or phone discussion. Of the original 640 projects, 215 were found to be current. A detailed description of each project is included in the report.

According to this study, until several years ago tribology research emphasized component development, fluid film and elastohydrodynamic lubrication, and concentrated contacts. Since then the emphasis has shifted dramatically, and research efforts now concentrate on lubricants, materials and coatings, and friction and wear mechanisms. There is still considerable interest in rolling contact bearings and seals, as well as in early failure detection in maintenance technology.

The study also concluded that most current tribology research is related to DOO objectives of longer life, low maintenance/ failure-free machinery, and the basic understanding of friction, wear, materials, and coatings. High-temperature lubrication also continues to be a major objective in tribology research; the effects of new matertals and solid lubricants on current temperature limitations are also being studied. Coatings are receiving the most attention in general materials development. Figure ES.5 shows a breakdown of the materials considered in the 215 projects.

The author also concluded that current programs generally do not emphasize energy or materials conservation. Design predictability and composite materials are other areas that are receiving little attention. Finally, the study concluded that current
U.S. Government high-temperature lubrication work is the most applicable to energy conservation goals.

INDUSTRY PERCEPTIONS OF GENERIC RESEARCH NEEUS IN TRIBOLOGY

Because transferring information to industries is a major part of the ECUT program, ECUT conducted a survey of industry perspectives on tribology R\& needs. This survey, conducted by Sibley and Zlotnick, involved interviewling industry contacts to discover what research results are needed.

The authors held in-depth discussions wth engi neers and managers from 27 companies. These companies were chosen by definting different tribological categories (such as transportation, power plants, seals, gears, aerospace, etc.). At least one company was then selected for each category, and two or three were chosen for categories that are particularly important to the ECUT program. The purpose of this study was not to produce statistically significant findings, but rather to represent many different viewpoints and a variety of interests.

The authors' main emphasis was on determining the engineering limitations imposed by tribology considerations. They also tried to determi ne the type and funding level of current generic tribology R\&D in each company, although only pon-proprietary information was available. (a)

Based on the levels of generic tribology R\&D in the 27 individual companies, the authors then estimated total tribology R\&D in each industrlal segment. Although this approach is obviously $11 \mathrm{mited}$, reasonably

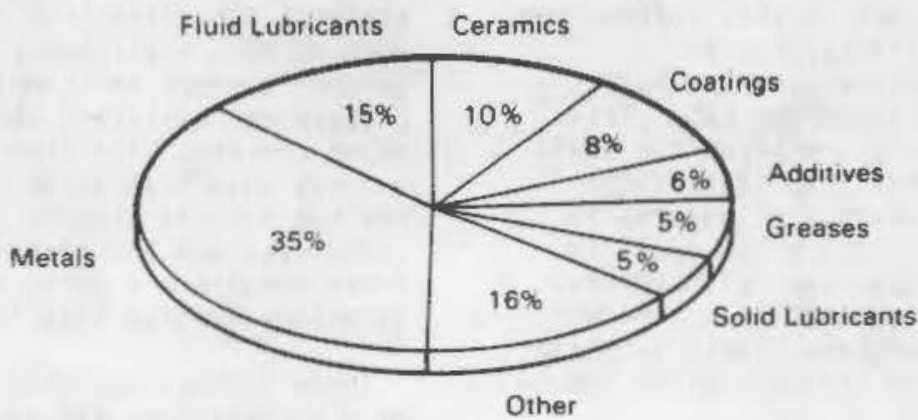

FIGURE ES.5. Materials Under Consideration in the 215 Current Government-Sponsored Tribology Projects

(a) "Generic" R\&D in this case is basic research that is not directed toward a specific end use or product. 
TABLE ES.3. Estimate of Generic Tribology R\&D and Total R\&D Budget for Representative Industries (In SM)

\begin{tabular}{|c|c|c|c|}
\hline Classification & Company & $\begin{array}{l}\text { Total } \\
\text { R\&D(a) } \\
\end{array}$ & $\begin{array}{c}\text { Generic } \\
\text { Tribology R\&D (b) } \\
\end{array}$ \\
\hline Liquid Lubricants & Mobil & 188 & 1 \\
\hline Transportation & Ford & 1764 & 1 \\
\hline Aerospace & Pratt \& Whitney & 835 & 0 \\
\hline Powerplants & Caterpillar & 234 & 0 \\
\hline Seals & Crane & 10 & $<1$ \\
\hline Rolling Elements & TRW & 109 & $>0$ \\
\hline Gears & Eaton & 100 & $>0$ \\
\hline sliding Bearings & Tribon & 0 & $>0$ \\
\hline Filters & Pall & 7 & 0 \\
\hline Small Mechanical & Xerox & 565 & $>0$ \\
\hline Ceramics & Norton & 26 & $<1$ \\
\hline Coatings & Union Carbide & 240 & $<1$ \\
\hline Forming & Bethlehem & 46 & $\leq 1$ \\
\hline & & 4124 & 6 \\
\hline
\end{tabular}

(a) From the report to the Securities and Exchange Comml ssion for 1982. (Source: "Business Week," June 20, 1983.)

(b) Based on discussions with research staff and referring to only company-funded generic tribology R \&D.

accurate estimates were developed of the amounts of generic tribology R\&D being conducted in each of the industrial segments. The results for the individual companies are sumarized in Table ES.3.

These authors concluded that industry funds only a very limited amount of generic tribology research. Some 'hidden' generic R\&D is incorporated into the companies' design manuals, but much of this information is proprietary. As illustrated in Table ES.3, some industry segments have little or no generic tribology R\&D. Tribology research efforts are often too small to be likely to improve the state-of-theart; ceramics is an example of an area in which the funding levels are too small to promote significant advances, although industry has expressed considerable interest in this area. However, the liquid lubricant research budget in the transportation industries is substantial.

The industry representatives expressed interest in the ECUT Tribology Program, and also in obtaining a fundamental physical understanding of tribological mechanisms. The industry contacts also requested more effective presentations of research results, especially results in a form that design and development engineers could readily use.
Another industry concern involved developing more realistic laboratory tests and more rational performance standards.

\section{CONCLUSIONS}

The six ECUT surveys summarized here were conducted to provide an overview of the major tribological sinks and the current state of U.S. tribology research. Although much of this preliminary ECUT work involved general surveys and samplings, the overall picture is consistent and reveals areas of major concern. The findings in the general surveys have been largely substantiated by the two focused studies on metalworking industries and the advanced diesel engine. These results are being used to support ECUT Tribology Program planning.

These surveys describe the current status of U.S. tribology R\&D in 1984; the findings will be updated as necessary. Much of the information is necessarily somewhat speculative and theoretical, and many of the general findings have not yet been fully corroborated. This is due in part to the lack of previous research; improving this initial information should be an important goal of current research. In particular, identifying tribological mechanisms should 
be emphasized in order to define specific research projects. Further discussion with industry representatives is also needed.

The five key results from these ECUT studies are listed below:

1. Advanced tribo-materials, coatings, and lubricants must be developed to further improve energy efficiency. Although tribological improvements can be made with the current technology, new and innovative materials and designs (such as the advanced diesel engt ne) are needed to significantly increase energy efficiency.

2. Tribological mechanisms that shorten equipment $11 \mathrm{fe}$ and cause excessive downtime and repair should be ident1 fied and studied. Initial research shows that these indirect energy losses from material wear are often greater than the di rect energy losses from friction. In addition to the energy conservation impacts, reducing these losses could also significantly improve industrial productivity.

3. Generic tribological research wt11 affect all three major sectors, since similar tribological mechanisms are found in many different processes. Although the transportation sector has the largest tribological energy loss and the greatest potential for energy savings, there is significant energy savings potential in all sectors. Thus research results must be effectively transferred to all sectors.

4. Meaningful performance tests and standards must be developed so that new designs and products can be accurately evaluated. Laboratory tests that accurately reflect real-world conditions are badly needed. Total system testing is vital, since tribological energy losses are often caused by complex interactions between all the components of a system.
5. Continuing communication wh th industry is critical to ensure that industry research needs are addressed and that the results are adequately transferred.

These results supported the development of the ECUT Tribology Program plan for 1985. The research program is divided into two parts. The Mechanisms component includes such areas as advanced tribo-materials R\&D, identifying and characterizing tribological mechantsms, and developing performance test requir rements. Projects in this area include developing new tribological materials, and modeling and experimental efforts to detemine physical and chemical interactions and processes in tribological systems. Liquid and solid lubricants, tribological coatings and surface modifications, and ceramic and cermet materials are specific topics to be considered. The Mechanisms area also includes efforts to develop novel characterization and testing procedures and diagnostic tools and equipment to assess the performance of tribological systems.

The second part of the research program, Design, includes such topics as design and reliability modeling of components, systems, and system assemblies. Industry is di rectly involved in these projects. The Design area will also establish a data center to gather and disseminate information on tribology. These projects concentrate on generic tribology R\&D, including energy losses from material wear.

Clearly, tribology research can have a major impact on energy use and conservation in the U.S. Much of the needed research identified in these studies is innovative and high-risk, which makes tribology a vital and appropriate area for ECUT support. Thus the ECUT Tribology Program, wh th industry particlpation and cooperation, wil continue its efforts to reduce the enormous energy losses caused by friction and wear. 
]

】

】

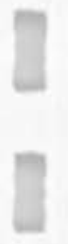

1]

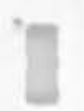

III

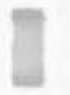

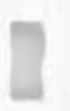

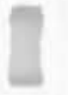

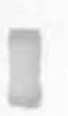

.

A

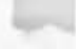

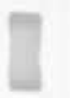

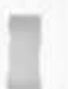

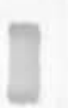

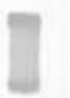

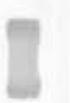

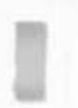


Tribology is the science of friction and material wear. To provide preliminary descriptions of the major tribological sinks typically found in industry, Pacific Northwest Laboratory (PNL) summarized the tribological activities found in each sink and estimated the resultant energy and material consumption. This research supports the mission of the Department of Energy's (DOE's) Energy Conversion and Utilization Technologies (ECUT) Tribology Project, which is to explore innovative lubrication and materials concepts for mitigating friction and wear in energy conversion and utilization devices. The results of this study will serve as background information for the ECUT Tribology Program staff as they identify and prioritize generic research opportunities in tribology.

Friction and material wear occur throughout all industries and are involved in many processes within each industry. These conditions make assessing tribological activity overall in industry very complex and expensive. Therefore, a research strategy to obtain preliminary information on only the most significant industrial tribological sinks was defined. This approach would provide timely data for developing the research plan within current budget constraints and would indicate where further, more detailed assessments would be most beneficial. To meet these goals, six industries were selected and reviewed. This approach allowed a sufficiently detailed review of each of the six industries rather than a cursory review of all industries.

The industries examined were selected according to both the magnitude of overall energy consumption (particularly machine drive) and the known presence of significant tribological sinks. The six industries chosen are as follows:

- Mining

- Agriculture

- Primary Metals

- Chemicals/Refining

- Food

- Pulp and Paper. 
The six industries were reviewed to identify and characterize the major tribology sinks. The initial energy and material consumption estimates are based upon technical analysis, industry contacts, and generally available data sources; the assumptions and limitations of the estimates are described in each industry chapter. The estimates are approximate, although they provide an effective basis for comparing the relative significance of the identified sinks. The descriptions only address the energy implications of each significant sink (both direct and indirect losses); issues such as effects upon industrial productivity, economic considerations, etc., are not included.

\section{S.1 SUMMARY OF RESULTS}

The study identified important tribological sinks in each selected industry, based on both friction and material wear energy losses and on the tribological mechanisms and materials involved. Figure S.1 and Table S.I show the key results for each of the six industries.

The first conclusion from this study confirmed earlier claims that losses from material wear are greater than energy losses from friction; the wear losses in five of the industries were found to be more than twice as large as the friction losses. (a) The study also concluded that reducing material wear rates to improve equipment life and reliability would also significantly improve industrial productivity. The industry representatives interviewed strongly emphasized the positive impacts that tribological research could have on operational productivity.

\section{S.2 INDUSTRY HIGHLIGHTS}

The most significant results found in each of the six industries reviewed are summarized below. For each industry, the most significant sinks and the important implications are presented.

(a) These five industries had estimates of both friction and material wear losses; the sixth, Chemicals/Refining, did not have estimates of wear losses. 


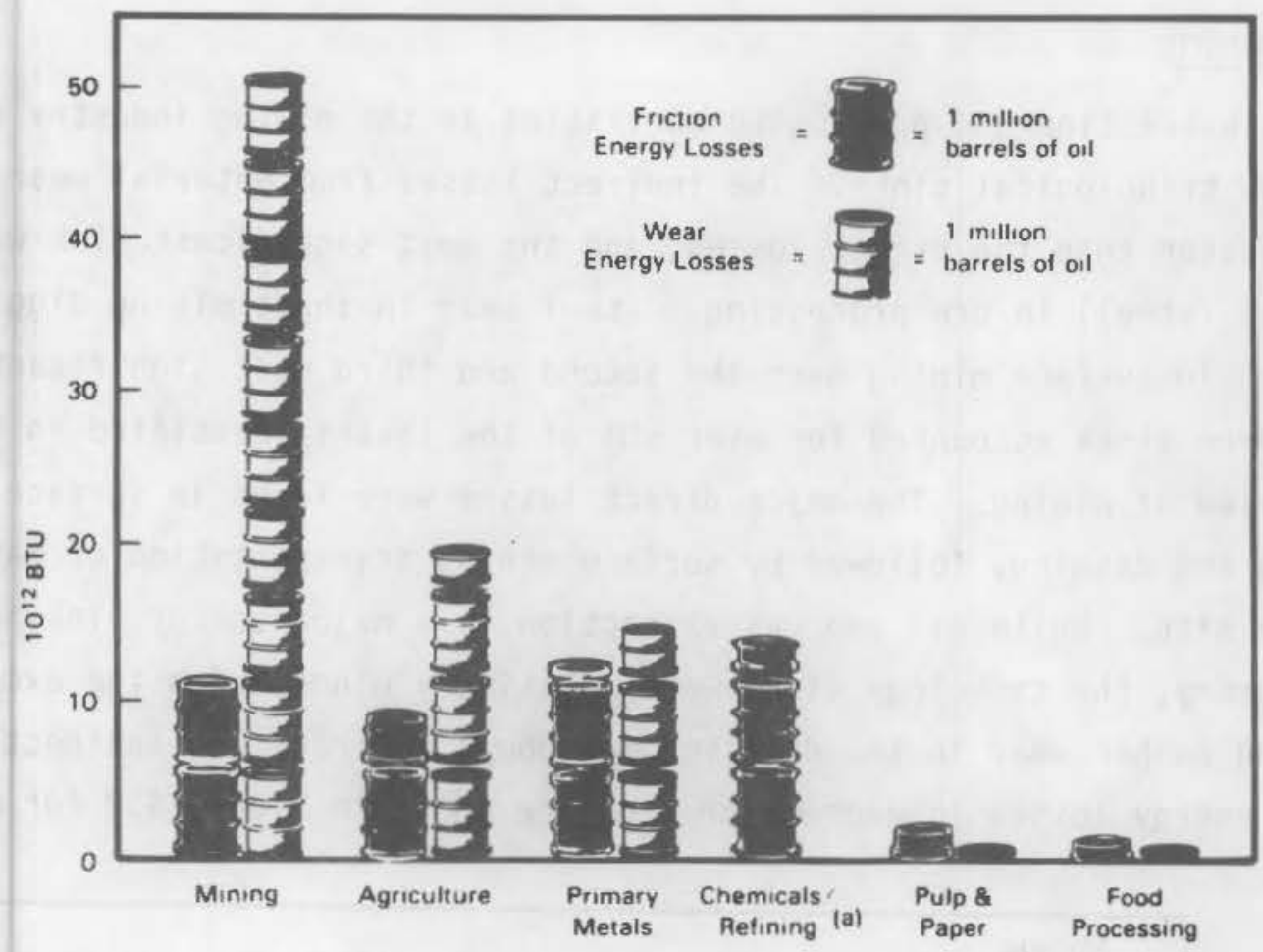

(a) Wear energy losses not estimated for Chemicals/Refining.

FIGURE S.1. Annual Friction and Wear Losses in Surveyed Industries

TABLE S.1. Primary Mechanisms in Friction Energy Losses and Principal Materials Involved in Wear Energy Losses

\begin{tabular}{|c|c|c|}
\hline Industry & Mechanisms & Materials \\
\hline Mining & 3-body abrasion, friction & $\begin{array}{l}\text { Iron, steel and alloys, } \\
\text { aluminum, rubber }\end{array}$ \\
\hline Agriculture & 3-body abrasion, friction & Steel, rubber, lubricants \\
\hline Primary Metals & Hot rolling inefficiencies & Steel and alloys \\
\hline Chemicals/Refining & Friction, erosion, abrasion & Not studied \\
\hline Pulp and Paper & Friction & $\begin{array}{l}\text { Steel and alloys, chromium- } \\
\text { molybdenum alloys, grinding } \\
\text { stones }\end{array}$ \\
\hline Food Processing & Erosion, abrasion & Steel and alloys \\
\hline
\end{tabular}




\section{S.2.1 Mining}

Ore extraction and processing activities in the mining industry result in important tribological sinks. The indirect losses from material wear were five times greater than the direct losses, and the most significant sink was material wear (steel) in ore processing. Steel wear in shaft mining digging and tire wear in surface mining were the second and third most significant sinks; these three sinks accounted for over $80 \%$ of the losses identified in this initial review of mining. The major direct losses were found in surface mining exposing and digging, followed by surface mining transportation of materials at the mine site. While oil and gas extraction is a major energy sink in the mining industry, the tribology sinks were relatively minor, with the exception of steel and rubber wear in the drilling mud pumps. Direct and indirect tribological energy losses in each major sink are shown in Figure S.2 for mining.

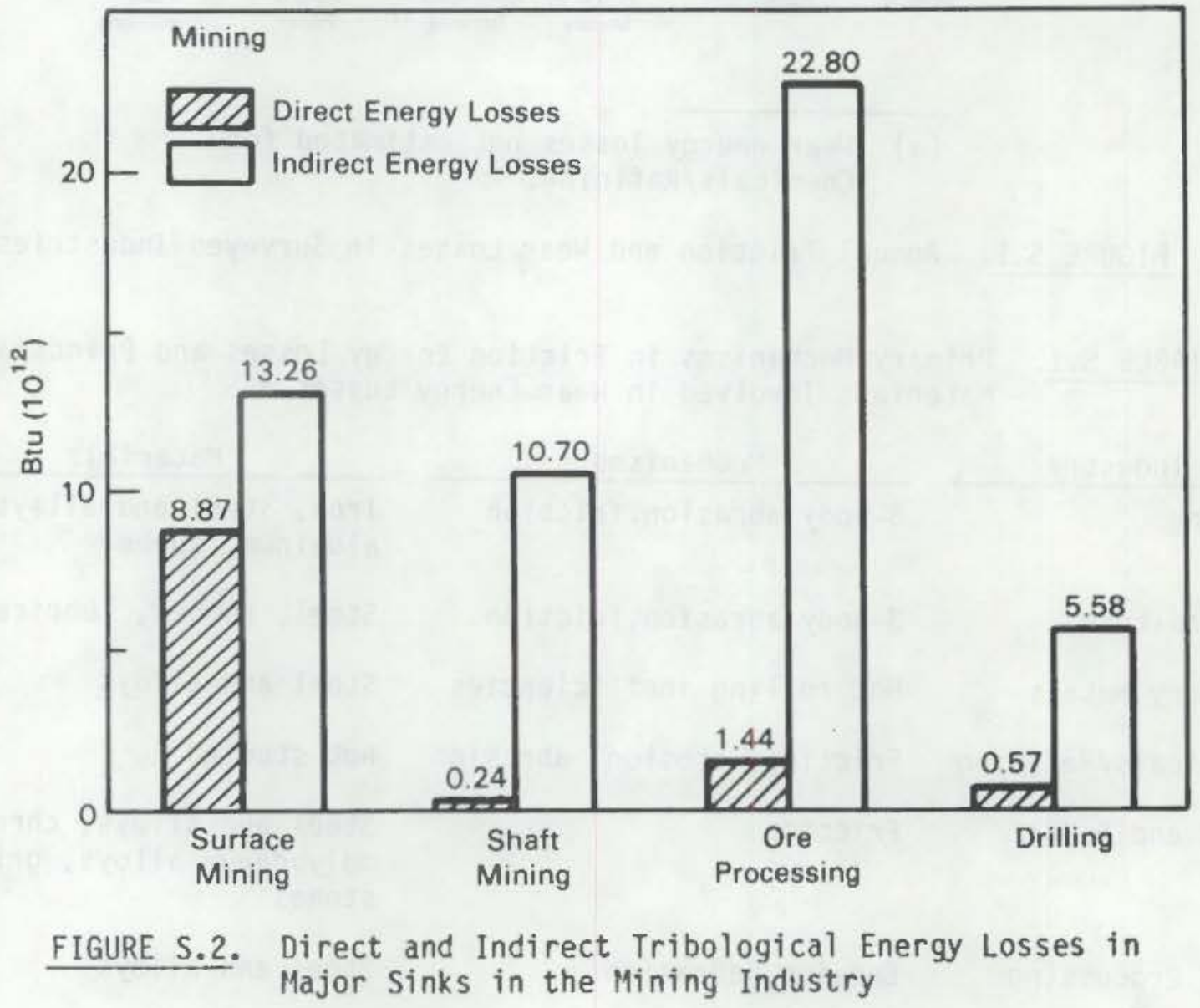


The mining industry offers important applications for basic tribology research. Three-body abrasion and friction were the most frequent tribological mechanisms in the identified sinks; the resulting energy losses were generally more significant than in the other industries reviewed. Material wear in ore processing, extraction, and transporting resulted in significant embodied energy losses. $0 i 1$ and gas extraction sinks contained relatively insignificant energy losses, although they are excellent examples of sinks where the most dramatic potential benefits might be productivity improvements (e.g., improved drill bit life reduces the need to pull drill pipe for bit replacement).

\section{S.2.2 Agriculture}

For the major tribological sinks identified in agriculture, the indirect energy losses were estimated to be more than twice as large as the direct energy losses (see Figure S.3). The erosion of steel from tillage implements and the draft (pulling) requirements of tillage were the two largest sinks, followed by tractor tire wear and lubricant loss. Direct consumption and

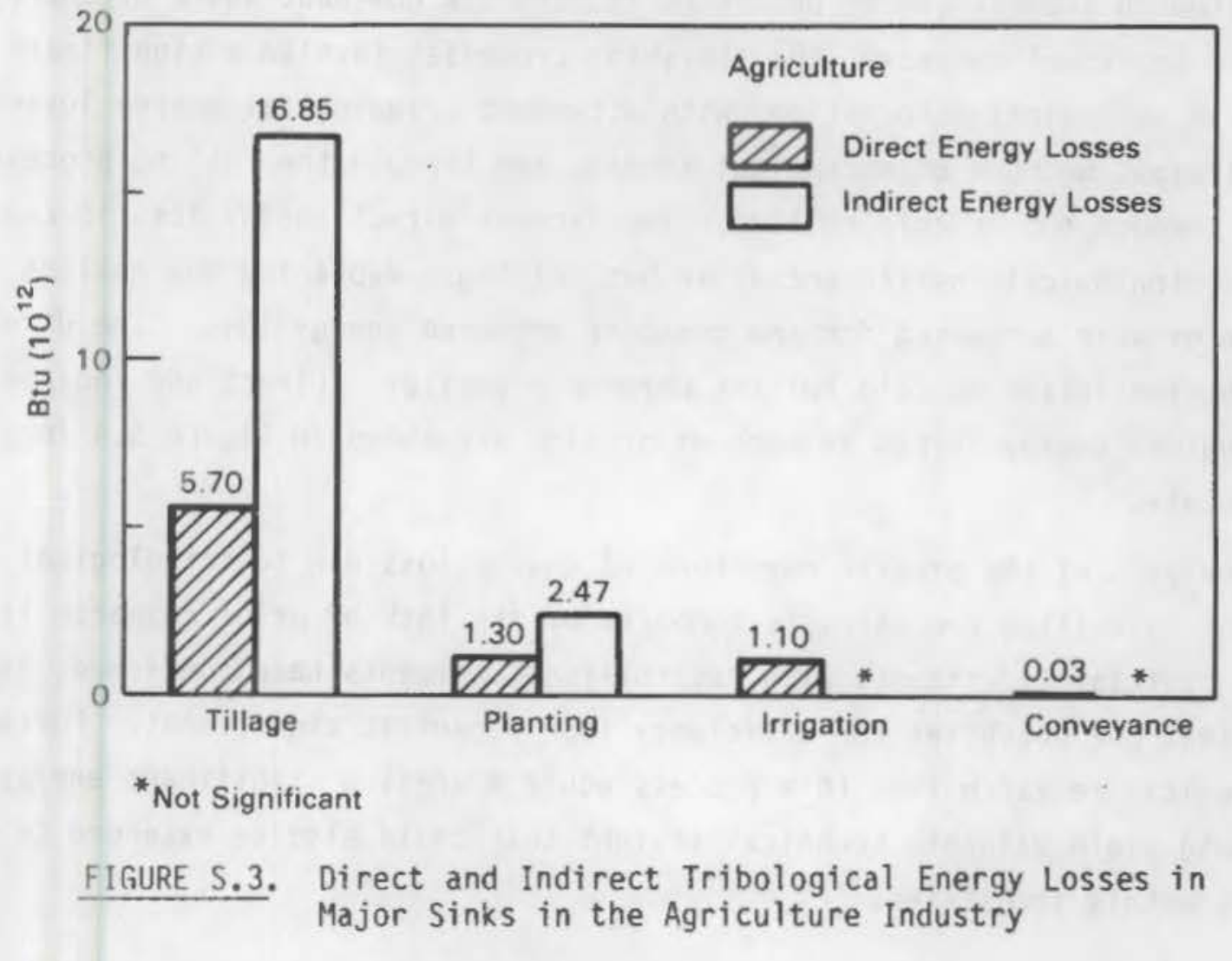


material wear in planting equipment were also important. The sinks in livestock production were relatively insignificant, and the losses in harvesting (i.e., combines) were not characterized because of the complexity of the process.

The main result from the agriculture analysis is the importance of the tribology activities in soil tillage. Both the direct and indirect losses in tillage are significant, and these losses can be reduced with further basic tribology research. The most frequent tribological mechanisms identified in the analysis were three-body abrasion and high friction. Energy consumption in irrigation is high, yet the tribological sinks were found to be relatively minor. The sinks involved in harvesting with combines appear to merit further review; the sinks involve more than 50 important parts that experience at least medium wear rates. Obtaining valid replacement rate data for combines, however, exceeded the resources available for this initial review.

\section{S.2.3 Primary Metals}

Although thermal energy processes require the dominant share of energy in the iron and steel industry, the finishing processes involve a significant degree of mechanical deformation, with attendant tribological energy losses. The principal methods of mechanical forming are through the rolling processes, either through hot or cold rolling. The largest direct energy loss is caused by the tribological inefficiencies in hot rolling. Replacing the rollers because of wear accounted for the greatest embodied energy loss. The direct and embodied losses in cold rolling were much smaller. Direct and indirect tribological energy losses in each major sink are shown in Figure S.4 for primary metals.

Analysis of the precise magnitude of energy loss due to tribological inefficiency in rolling processes is hampered by the lack of prior research in this field. Initial experiments with hot rolling lubricants have confirmed, however, that the potential for efficiency improvement is significant. Further tribological research into this process would address a significant energy sink and would yield valuable technical insight that could also be extended to other primary metals industries. 


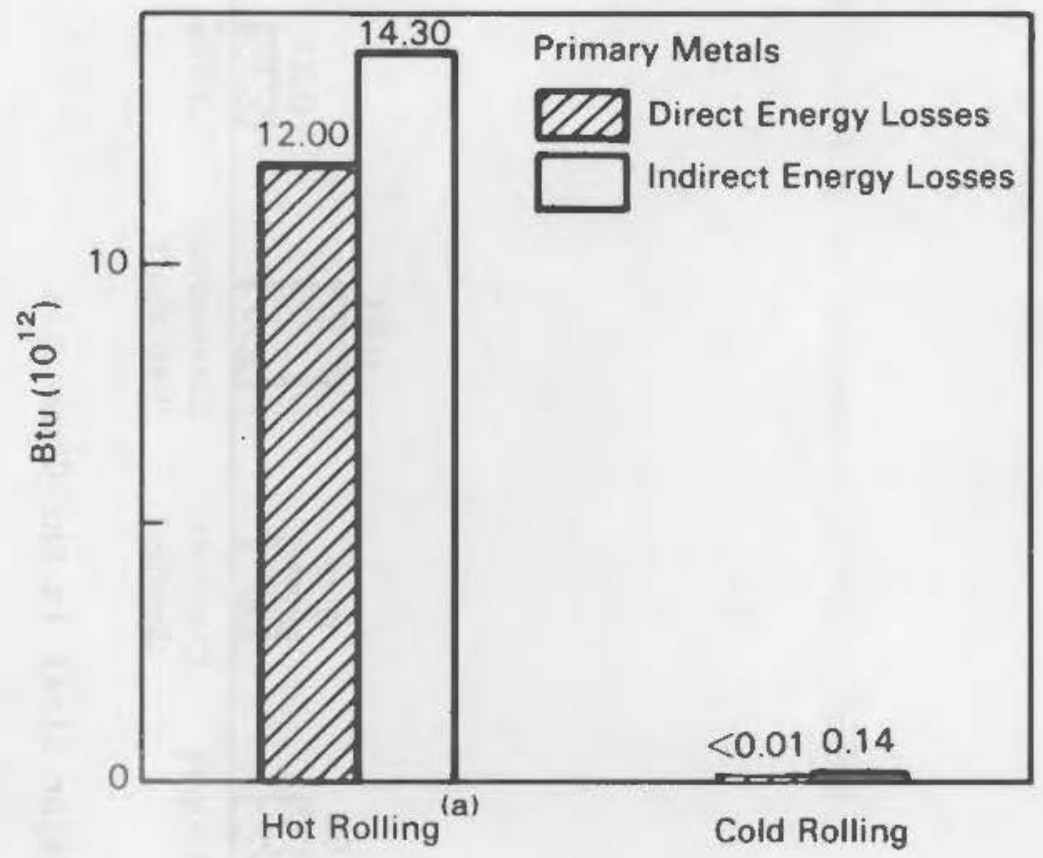

FIGURE S.4. Direct and Indirect Tribological Energy Losses in Major Sinks in the Primary Metals Industry

\section{S.2.4 Chemicals and Petroleum}

The chemicals and petroleum industries use enormous amounts of energy, and the nature of this energy use is very diverse. Studying tribological losses, which are widespread in these industries but small in comparison with the large process heat energy losses, is very difficult. A variety of assumptions were required to generate an estimate of direct tribological losses, and indirect losses were not quantified because of the complexity of estimating the replacement rates of the vast number of material parts in these industries. Most of the tribological sinks assessed were devices driven by electric motors. None of these devices had significant tribological losses as a percentage of input power requirements; the final values for annual energy losses depended primarily on the total stock of each type of motor-driven equipment in the industry. As a result, pumps, compressors and blowers were the most important sinks, with pumps alone accounting for over half of the direct losses. Other equipment such as mixers, crushers and grinders were about an order of magnitude lower in annual losses. The direct tribological energy losses are shown in Figure S.5. 


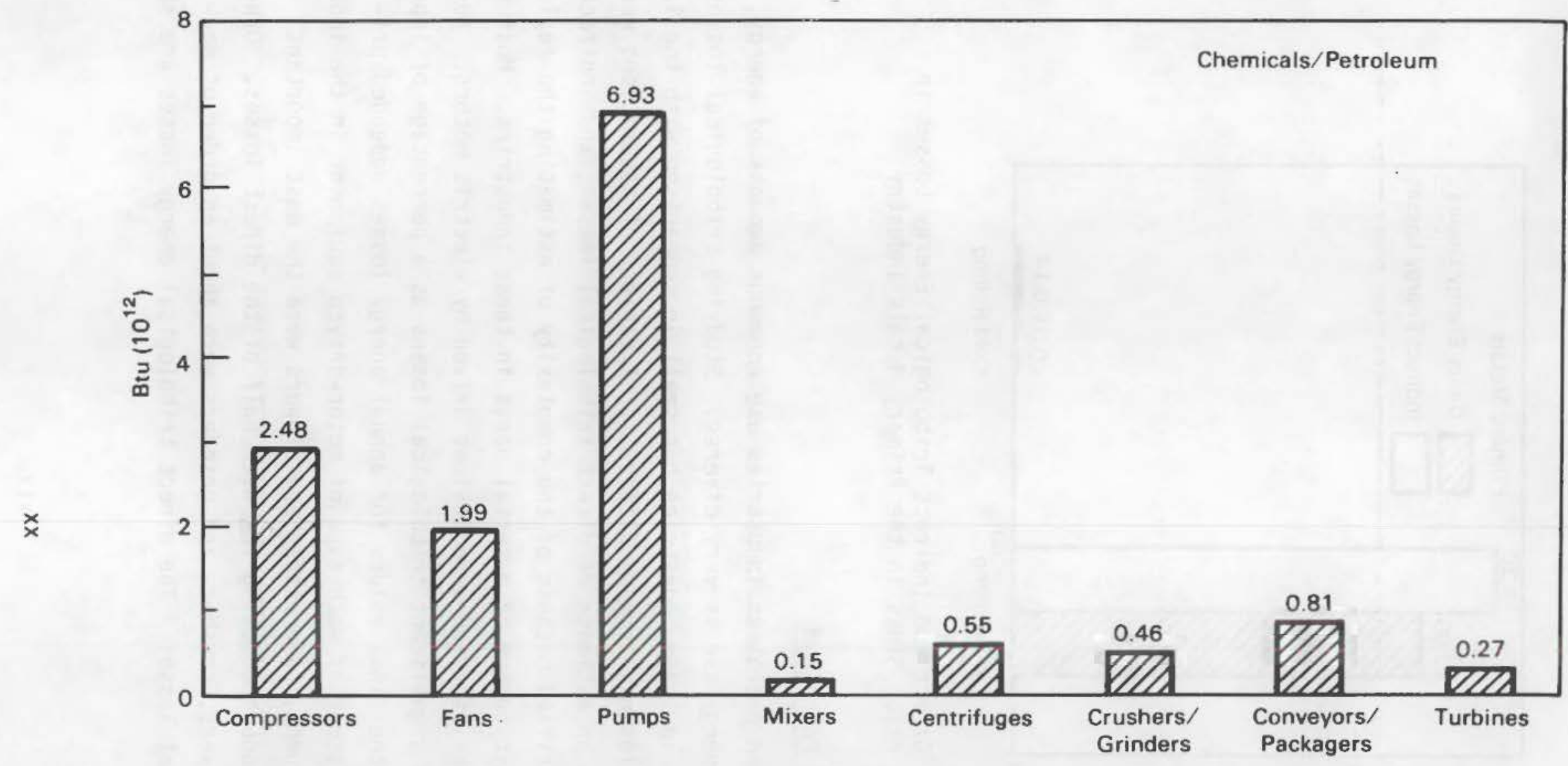

FIGURE S.5. Direct Tribological Energy Losses in Major Sinks in the Chemicals and Petroleum Industry (a)

(a) Indirect losses were not quantified because of the complexity of estimating the replacement rates of the vast number of material parts. 
The overall level of direct annual tribological losses identified in the petroleum and chemical industries was significant, although probably not as significant as the almost-unquantifiable indirect losses. Material wear occurs in most motor-driven chemical industry devices, and energy costs of replacement and downtime are high. A significant fraction of the failures are due to tribological causes. The reliability of such process equipment is extremely important to the industry because many processes operate 24 hours a day. Chemicals and petroleum industry interest in tribology is certainly high but is based primarily on factors such as indirect energy and production concerns. Additional review of the complex indirect losses of this industry is merited.

\section{S.2.5 Pulp and Paper}

The most significant tribological sinks found in the pulp and paper industry were 1) wood preparation and 2) pulp making. Other activities specifically identified as having significant tribological loss mechanisms were tree harvesting, pulpwood debarking, pulpwood chipping, stone-groundwood pulping, chipgroundwood pulping, and hydropulping. Except for harvesting, all of the operations are principally powered by electric motors. The combined annual tribological energy loss estimated for the three pulping processes was approximately 1.2 trillion Btu/year or $91 \%$ of the total energy loss estimated for the sinks reviewed. Steel and its alloys were the most common material types subject to wear; grinding stones were also used in mechanical pulping. Direct. and indirect tribological energy losses in each major sink are shown in Figure S.6.

Tribological mechanisms are an essential and beneficial feature of the pulp and paper operations evaluated in this report. Friction is essential to activities such as pulpwood debarking, pulpwood chipping, and mechanical pulping. Although the total estimated tribological energy loss was not as large as estimates for the other industries reviewed, the pulp and paper industry does contain well-defined unit operations that can benefit from advancements in basic tribology research. However, further analysis of pulp and paper operations to better segregate "necessary" friction from "wasteful" 


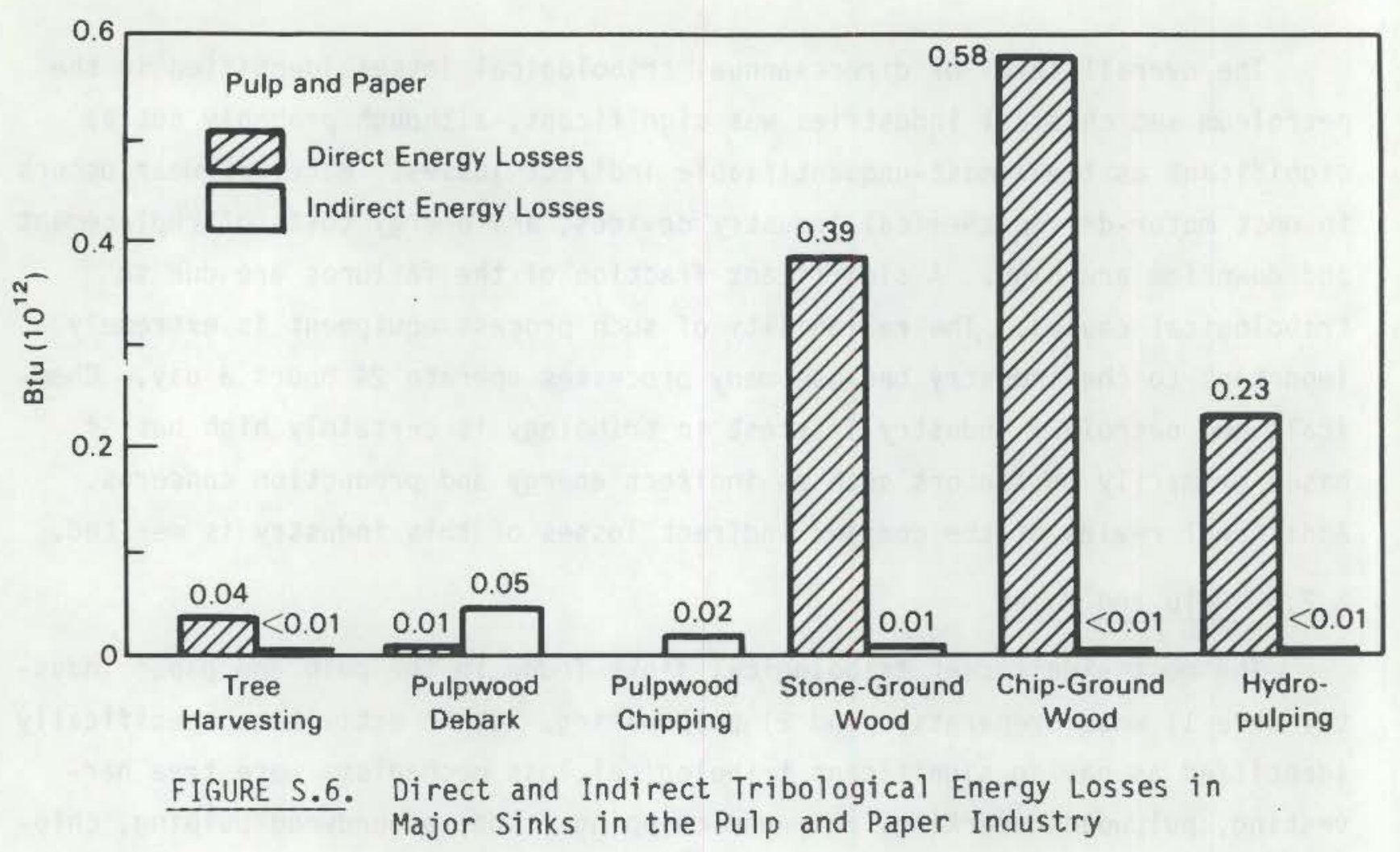

friction is needed. This concept may have implications for tribological mechanisms in other industries where the necessity of having a minimum level of friction is not as obvious.

\section{S.2.6 Food Processing}

The food processing industry includes an extremely large number of products and manufacturing processes. The diversity of the industry makes it difficult to generalize about tribological mechanisms and losses. Although many operations are functionally similar across product lines, the specific equipment is often unique to a particular product, making a generic analysis of individual operations very difficult. Size reduction and material conveyance were identified as the two most significant tribological loss activities. Size reduction operations (e.g. cutting, shredding, grinding) result in erosion and abrasion of equipment. Conveying is associated with the frictional wear of bearings, belts, and other parts. Electricity is the principal energy source for both size reduction and conveying operations. Five percent of direct energy input was attributed to frictional losses from conveyors. The total 
conveyor loss of 520 billion Btu/yr was the largest tribological sink identified for food processing. Direct tribological energy losses in each major sink are shown in Figure S.7.

The tribological sinks identified in the food industry are small compared to the other industries covered in this report. However, the two most important tribological activities identified for food processing (size reduction and conveyance) are also common to other industries. Tribological losses in conveyors and other transport systems seem particularly endemic to the manufacturing industry. Size reduction is especially important in mining and pulp and paper, as well as food processing. Size reduction operations often involve significant material wear. The development of more wear-resistant materials would dramatically reduce tribological losses in several industries.

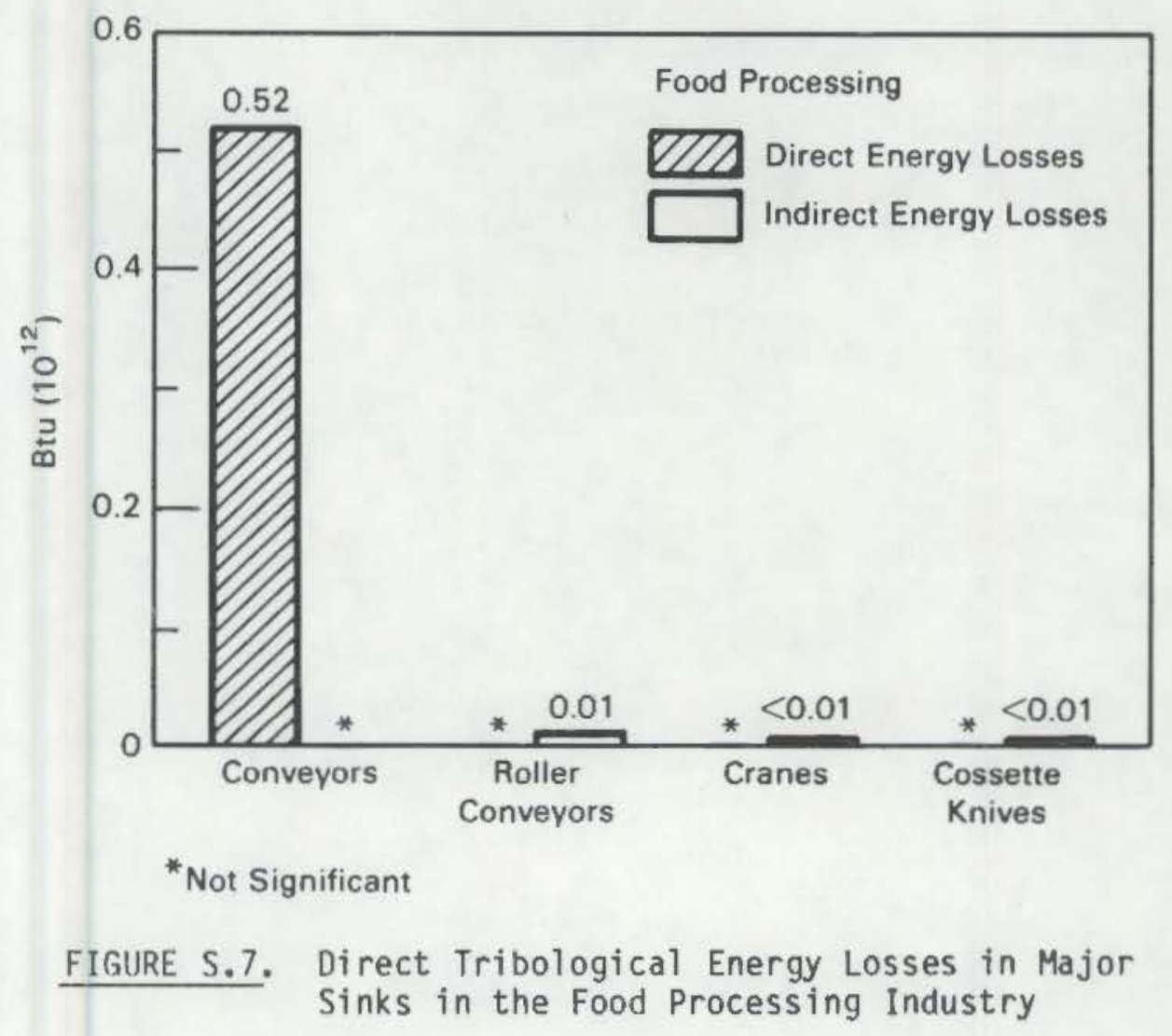




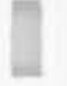

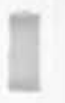

III

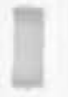

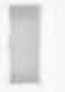

]

']

III

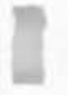

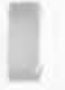

5

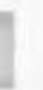

.

n-

.

(

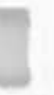

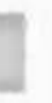

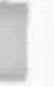

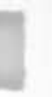

D 


\section{CONTENTS}

EXECUTIVE SUMMARY

SUMMARY

$x i i j$

1.0 INTRODUCTION

1.1

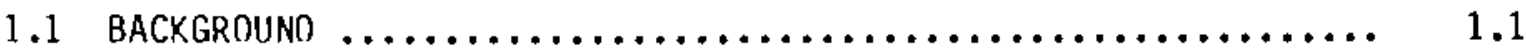

1.2 APPROACH $\ldots \ldots \ldots \ldots \ldots \ldots \ldots \ldots \ldots \ldots \ldots \ldots \ldots \ldots \ldots \ldots \ldots \ldots \ldots \ldots, 1.1$

1.3 CHAPTER CONTENTS $\ldots \ldots \ldots \ldots \ldots \ldots \ldots \ldots \ldots \ldots \ldots \ldots \ldots \ldots \ldots \ldots \ldots \ldots$

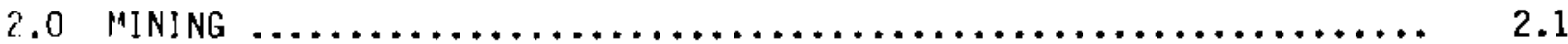

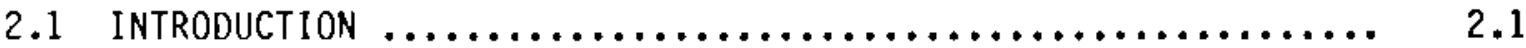

2.1 .1 Energy Consumption in Mining $\ldots \ldots \ldots \ldots \ldots \ldots \ldots \ldots . \ldots \ldots$

2.1 .2 Mining Operation Activities ................. 2.6

2.2 MINING OF METALLIIC ORES, COAL, AND NONMETALLIC MINERALS .... 2.7

2.2.1 Surface Mining $\ldots \ldots \ldots \ldots \ldots \ldots \ldots \ldots \ldots \ldots \ldots \ldots \ldots . . \ldots \ldots$

2.2 .2 Shaft Mining $\ldots \ldots \ldots \ldots \ldots \ldots \ldots \ldots \ldots \ldots \ldots \ldots \ldots \ldots . \ldots \ldots$

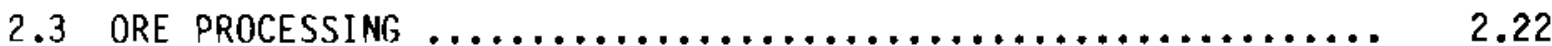

2.3 .1 Direct Energy Losses in Ore Processing ............ 2.22

2.3.2 Indirect Energy Losses $\ldots \ldots \ldots \ldots \ldots \ldots \ldots \ldots \ldots \ldots \ldots \ldots .2 .23$

2.3.3 0ther Ore Processing Activities ................ 2.24

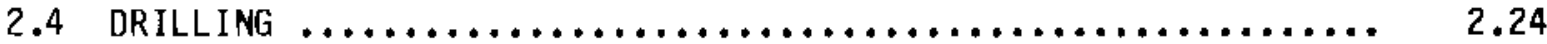

2.4 .1 Drill String $\ldots \ldots \ldots \ldots \ldots \ldots \ldots \ldots \ldots \ldots \ldots \ldots \ldots \ldots \ldots .2 .26$

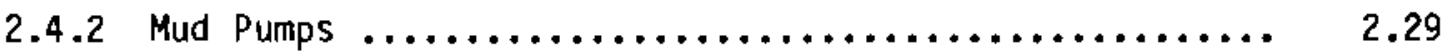

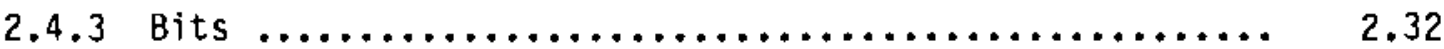

2.5 SUMMARY OF TRIBOLOGICAL ENERGY LOSSES IN MINING $\ldots \ldots \ldots \ldots \ldots \ldots .2 .34$

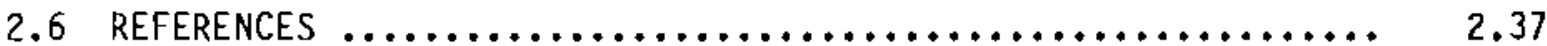

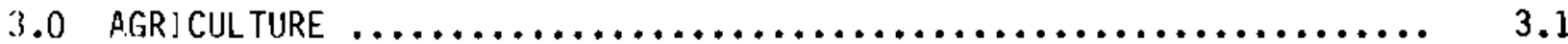


3.1 INTRODUCTION $\ldots \ldots \ldots \ldots \ldots \ldots \ldots, \ldots \ldots \ldots \ldots \ldots \ldots \ldots \ldots, \quad 3.1$

3.1.1 Agriculture End-Use Energy Consumption ............ 3.1

3.1.z Major Agricultural Processes .................... 3.4

3.2 MAIIOR TRIBOLOGICAL SIHKS IN AGRICULTURE $\ldots \ldots \ldots \ldots \ldots \ldots \ldots, 3.11$

3.2.1 Sources of Iribological Losses ................... 3.11

3.?.2 A Tribological Perspective on Crop and Livestock Production .................................... 3.22

3.3 SUMMARY OF TRIBOLDGICAL SINKS IN AGRICULTURE ............. 3.23

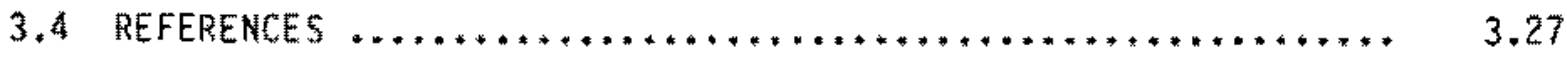

4.0 PRIMARY METALS - THE IRON AND STEEL INDUSTRY $\ldots \ldots \ldots \ldots \ldots \ldots \ldots .4 .1$

4.1 GENERAL INDUSTRY DESCRIPTION $\ldots \ldots \ldots \ldots \ldots \ldots \ldots \ldots \ldots \ldots \ldots, 4.1$

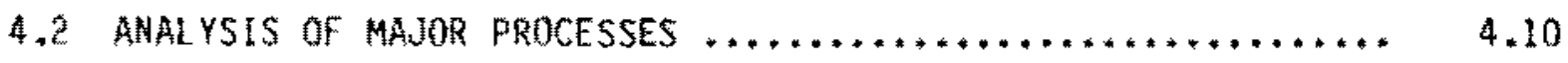

4.2 .1 Major Iron and Stee 1 Processes ................... 4.10

4.2.2 Processes Containing Significant Tribological sinks ....................................... 4.13

4.2.3 Processes Not Containing Significant Tribological Losses ............................ 4.19

4.3 SIIMMARY $\ldots \ldots \ldots \ldots \ldots \ldots \ldots \ldots \ldots \ldots \ldots \ldots \ldots \ldots \ldots \ldots \ldots \ldots \ldots \ldots, 4,21$

4.4 REFERENCES $\ldots \ldots \ldots \ldots \ldots \ldots \ldots \ldots \ldots \ldots \ldots \ldots \ldots \ldots \ldots \ldots \ldots \ldots \ldots, 4.23$

5.0 CHEMICAL ANO PETROLEUM REFINING INDUSTRIES $\ldots \ldots \ldots \ldots \ldots \ldots \ldots \ldots, 5.1$

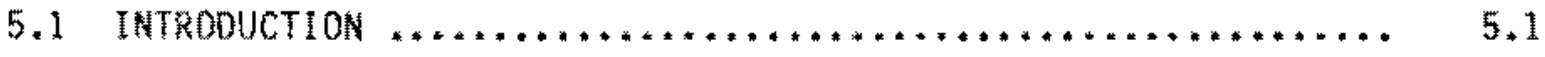

5.1.1 Energy Consumption in Chemical and Petroleum Refining 5.1

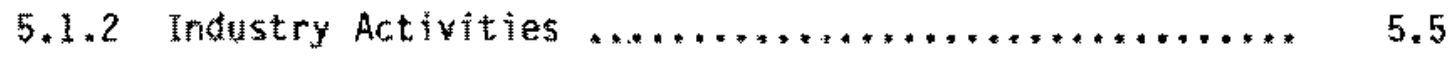

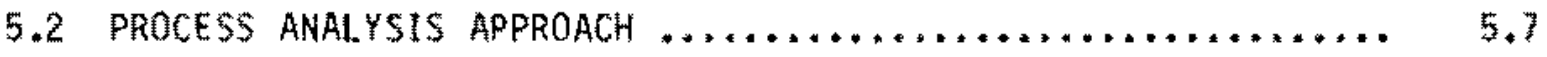

5.2 .1 Drexel Industrial process Data .................... 5.9

5.2.2 Tribological Loss Estimation ................... 5.9

5.3 DIRECT TRIBOL OGICAL LOSSES FOR CHEMICAL. PROCESS

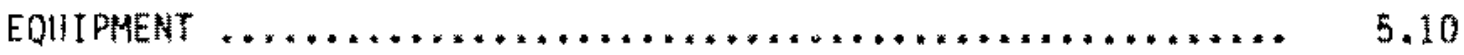


5.3 .1 Turbines $\ldots \ldots \ldots \ldots \ldots \ldots \ldots \ldots \ldots \ldots \ldots \ldots \ldots, \quad 5.10$

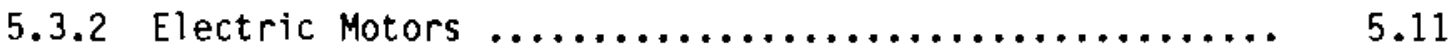

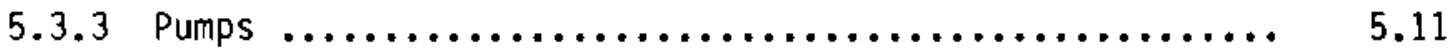

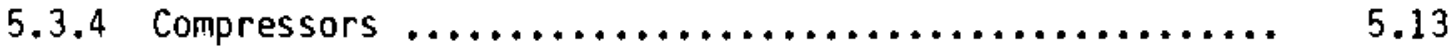

5.3 .5 Blowers $\ldots \ldots \ldots \ldots \ldots \ldots \ldots \ldots \ldots \ldots \ldots \ldots \ldots \ldots \ldots \ldots, \quad 5.13$

5.3 .6 Mixers and Agitators $\ldots \ldots \ldots \ldots \ldots \ldots \ldots \ldots \ldots \ldots . .6 .13$

5.3.7 Centrifuges $\ldots \ldots \ldots \ldots \ldots \ldots \ldots \ldots \ldots \ldots \ldots \ldots \ldots \ldots, \quad 5.14$

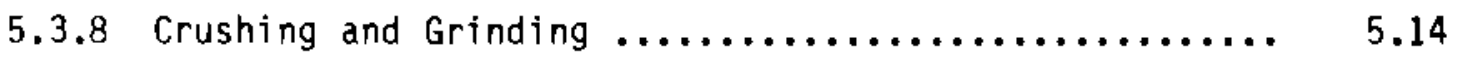

5.3.9 Conveyors, Packagers, Balers, and other Complex Devices ....................................... 5.14

5.4 SUMMARY AND CONCLUSIONS $\ldots \ldots \ldots \ldots \ldots \ldots \ldots \ldots \ldots \ldots \ldots \ldots \ldots, 5.14$

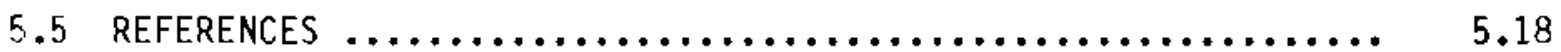

6.0 PULP AND PAPER $\ldots \ldots \ldots \ldots \ldots \ldots \ldots \ldots \ldots \ldots \ldots \ldots \ldots \ldots \ldots \ldots \ldots \ldots \ldots \ldots \ldots \ldots, 6.1$

6.1 INTRODUCTION $\ldots \ldots \ldots \ldots \ldots \ldots \ldots \ldots \ldots \ldots \ldots \ldots \ldots \ldots \ldots \ldots \ldots \ldots, 6.1$

6.1 Energy Consumption in Pulp and Paper .............. 6.1

6.1 .2 Pulp and Paper Operational Activities ............. 6.2

6.1 .3 Industry Production Levels $\ldots \ldots \ldots \ldots \ldots \ldots \ldots \ldots \ldots .6 .6$

6.1 .4 Processes Not Containing Significant
Tribological Losses $\ldots \ldots \ldots \ldots \ldots \ldots \ldots \ldots \ldots \ldots \ldots \ldots \ldots \ldots \ldots \ldots$

6.2 ANALYSIS OF TRIBOLOGICAL LOSSES IN THE PULP AND PAPER

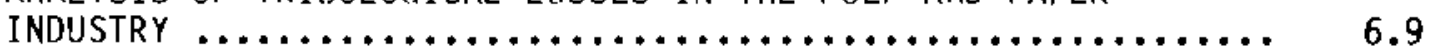

6.2 .1 Wood Preparation $\ldots \ldots \ldots \ldots \ldots \ldots \ldots \ldots \ldots \ldots \ldots \ldots .6 .6 .6$

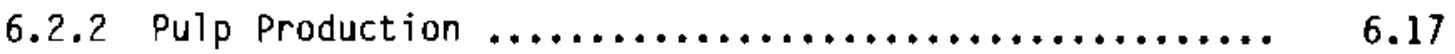

6.3 SUMMARY OF TRIBOLOGICAL ENERGY LOSSES IN PULP AND PAPER ..... 6.24

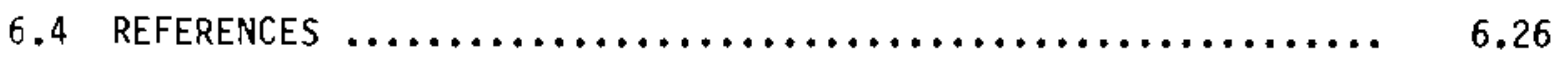

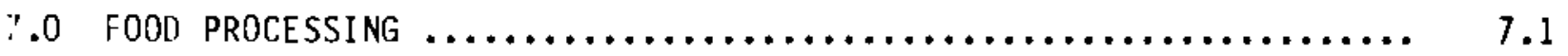

7.1 INTRODUCTION $\ldots \ldots \ldots \ldots \ldots \ldots \ldots \ldots \ldots \ldots \ldots \ldots \ldots \ldots \ldots \ldots \ldots \ldots \ldots \ldots \ldots, 7.1$ 
7.1.1 Energy Consumption in Food Processing ............ 7.1

7.2 FOOD PROCESSING OPERATIONAL ACTIVITIES $\ldots \ldots \ldots \ldots \ldots \ldots \ldots \ldots . . \ldots$

7.2 .1 Analytical Approach $\ldots \ldots \ldots \ldots \ldots \ldots \ldots \ldots \ldots \ldots \ldots . \ldots \ldots$

7.3 TRIBOLOGICAL LOSSES IN FOOD PROCESSING CONVEYING SYSTEMS $\ldots . .7 .6$

7.3.1 Direct Tribological Losses Associated with Conveyors ........................... 7.6

7.3.2 Indirect Tribological Losses in Conveying Systems .... 7.7

7.4 TRIBOLOGICAL LOSSES IN OTHER FOOD PROCESSING OPERATIONS $\ldots . .7 .11$

7.4 .1 Size Reduction Equipment $\ldots \ldots \ldots \ldots \ldots \ldots \ldots \ldots \ldots \ldots \ldots . \ldots \ldots$

7.4 .2 Mixers $\ldots \ldots \ldots \ldots \ldots \ldots \ldots \ldots \ldots \ldots \ldots \ldots \ldots \ldots \ldots \ldots \ldots \ldots . . \ldots \ldots$

7.4.3 0ther Size Reduction Equipment ............... 7.12

7.5 SUMMARY OF TRIBOLOGICAL ENERGY LOSSES IN THE FOOD

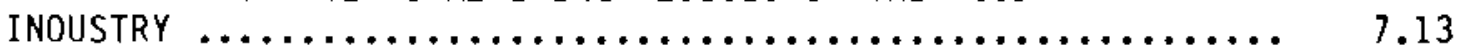

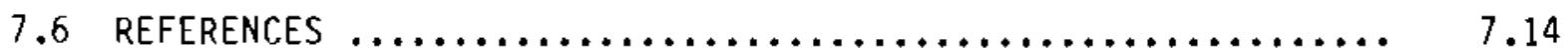




\section{FIGURES}

S.1 Annual Friction and Wear Losses in Surveyed Industries ......... $x$

S.2 Direct and Indirect Tribological Energy Losses in Major Sinks

in the Mining Industry ...................................... xvi

S.3 Direct and Indirect Tribological Energy Losses in Major Sinks

in the Agriculture Industry ................................. xpit

S.4 Direct and Indirect Tribological Energy Losses in Major Sinks

in the Pritnary Metals Industry ................................ $x i x$

S.5 Direct Tribological Energy Losses in Major Sinks

in the chemicals and petroleum Industry ....................... $x \times$

5.6 Diract and Indirect Tribological Energy Losses in Major Sinks

in the Pulp and Paper Industry .....................,........ xxif

\$.7 Direct Tribological Energy Losses in Major Sinks

in the Food Processing Industry ............................. xxili

1.1 Energy Use in the Industries Selected for Analys is $\ldots \ldots \ldots \ldots \ldots . .4$

1.2 Revised Infomation Flow Diagram ........................ 1.6

2.1 A Topical Surface Mining Operation .......................... 2.8

2.2 Surtace Mining Exposing and Digging Equipment ................ 2.9

3.3 Percent Carry-Back in Major Geological Divisions ............... 2.14

2.4 One Type of Continuous Mining Machine ...................... 2.20

2.5 Rotary Orilling Rig--Trbological Components Having Significant

Tribological Losses ...................................... 2.25

2.5 Anatomy of a Drill Pipe $\ldots \ldots \ldots \ldots \ldots \ldots \ldots \ldots \ldots \ldots \ldots \ldots \ldots \ldots \ldots \ldots \ldots, 2.27$

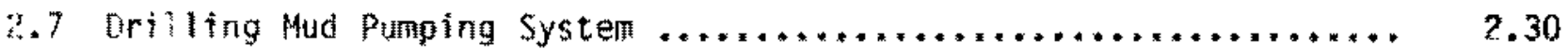

2.8 Schematic Drawing of Mud Pump Compression Chamber .............. 2.31

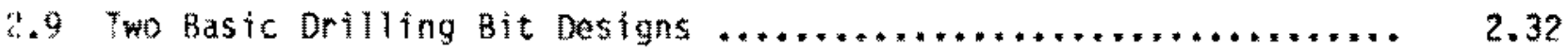

3.1 Labor and liachinery Inputs for production of Grain Corn .......... 3.4

3.2 Energy Consumption in Crop Production by Respective Crop ......... 3.7 
3.3 Grain Combine Harvester wth Example Tribological Sites

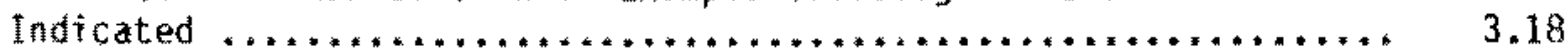

4.1 Major processes Involved in producing Iron and 5 teel ........... 4.5

4.2 Distribution of Energy Use in the Major Energy-Consuming processes $\ldots \ldots \ldots \ldots \ldots \ldots \ldots \ldots \ldots \ldots \ldots \ldots \ldots \ldots \ldots \ldots \ldots \ldots \ldots \ldots \ldots \ldots \ldots \ldots \ldots \ldots$

4.3 Distribution of the Different Forms of Energy and the Recycling

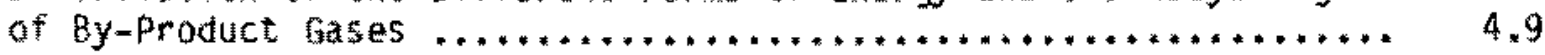

b.1 General States of Paper Making ........................... 6.10

6.? General Processes of Hood Preparation .................... 6.11 
TABLES

S.1 Primary Hechanisns in Friction Energy Losses and Principal

Materials Involved in Wear Energy Losses ................... xy

1,1 Candidate Industrial Process Categories $\ldots \ldots \ldots \ldots \ldots \ldots \ldots \ldots \ldots \ldots$

2.1 Energy Consumption in Mining $\ldots \ldots \ldots \ldots \ldots \ldots \ldots \ldots \ldots \ldots \ldots \ldots \ldots \ldots \ldots \ldots$. 2

1.2 Energy Consumption by Fuel Type in the Mining Industry $\ldots \ldots * \ldots * *$ z.2

2.3 Energy tonsumption by Fuel Type in Metal Mining .............. 2.3

c.4 Energy Consumption by Fuel Type in Anthractte Mining .......... 2.3

2.5 Energy Consumption by Fuel Type in Bituminous Coal and

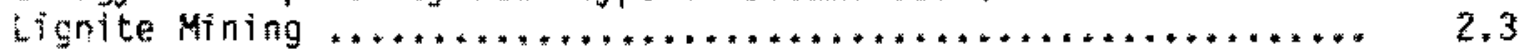

$z .6$ Energy Consumption by Fuel Type in 011 and Gas Extraction ...*... 2.4

2.7 Energy Consumption by Fuel Type in Nonnetallic Minerals, Except Fuels $\ldots \ldots \ldots \ldots \ldots \ldots \ldots \ldots * \ldots \ldots \ldots \ldots \ldots \ldots \ldots \ldots \ldots \ldots \ldots \ldots \ldots \ldots \ldots \ldots \ldots, \quad 2.4$

2.8 Purchased Fuels and Electric Energy in the Mining Industry $\ldots \ldots \ldots$ 2..5

2.9 Principal Products of the Mining Industry $\ldots \ldots \ldots \ldots \ldots \ldots \ldots \ldots \ldots \ldots$

2.10 Wirect and Indirect Tribological Energy Losses for Digging and Exposing in Surface Mining Operations ...................... 2.10

2.11 U.S. Production of Principal Minerals from Surfate Mines $\ldots \ldots * \ldots *$ 2.11

2.12 Yearly Lubricant Used by braglines $\ldots \ldots \ldots \ldots \ldots \ldots \ldots \ldots \ldots \ldots \ldots \ldots \ldots \ldots$. 2.11

2.13 Blade Life Under Various Digging Condftions .............. 2.13

2.14 Characterization of the Five Geological diqisions ............ 2.15

2.15 iransportation in Surface Mining $\ldots \ldots \ldots \ldots \ldots \ldots \ldots \ldots \ldots \ldots \ldots \ldots \ldots \ldots$ 2.17

2.16 Values Assumed for Estinating Direct Friction Losses in Conveyors $\ldots \ldots \ldots \ldots \ldots \ldots \ldots \ldots \ldots \ldots \ldots \ldots \ldots \ldots \ldots \ldots \ldots \ldots \ldots \ldots \ldots \ldots \ldots \ldots \ldots \ldots, 2.19$

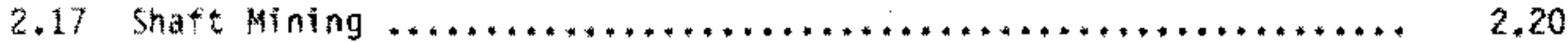

2.18 1.5 . Production of Principal Minerals from underground Mines .... 2.20

2.19 Direct Tribological Energy Losses in Grinding $\ldots \ldots \ldots \ldots \ldots \ldots \ldots \ldots \ldots \ldots$ 2.23

2.20 wear Rates in key ore processing steps $\ldots \ldots \ldots \ldots \ldots \ldots \ldots \ldots \ldots \ldots \ldots$. 2.23 
2.21 Tribological Losses for Orilling Components ................ 2.26

2.22 Operating Conditions of a Rotary Drilling Rig ............... 2.27

2.23 Generic Tribological Loss Mechanisms in Mining ............... 2.35

2.24 Annual direct Tribological Energy Losses in Mining ............ 2.36

2.25 Annual Indirect Tribological Energy Losses in Mining ........... 2.36

3.1 Major Agricultural Groups of the Standard Industrial

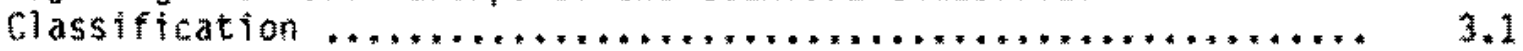

3.2 Energy Input by Farm Function and Region for Crop Production,

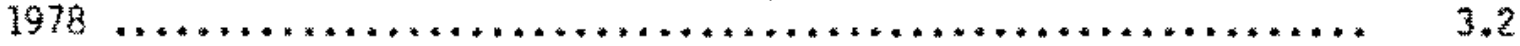

3.3 Energy Input by Operation and Region for Livestock Production,

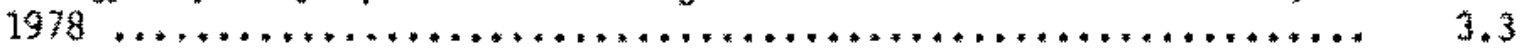

3.4 Crop Production Acreages for $1983 \ldots \ldots \ldots \ldots \ldots \ldots \ldots \ldots \ldots . . . . . . .6$

3.5 Machinery used in Crop production ......................... 3.8

3.6 Machinery Used in Livestock Production .................... 3.10

3.7 Summary of Tribological Losses in Crop and Livestock production .............................................. 3.12

3.8 Trips over the Field .................................. 3.13

3.9 Major Types of Tillage Implements Considered for Tribological Losses .................................................. 3.15

3.10 Major Types of Planting Implements Considered for Tribological

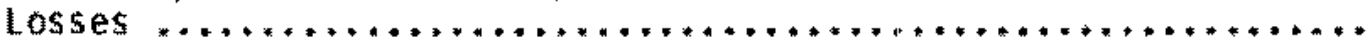

3.11 Major Types of Harvesting Machinery Considered for

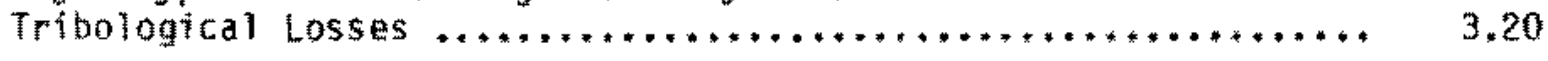

3.12 Some of the Nominal Parameters Used in Caiculating Direct Tribological Losses in Crop Handling and Transportation

3.13 Sumary Table for Tribological Energy Losses in the Agricultural Industry ................................. 3.25

3.14 Annual Direct Tribological Energy Losses in Agriculture ........ 3.26

3.15 Annual Indirect Tribological Energy Losses in Agriculture ...... 3.26

4.1 Purchased Fuels and Electricity in Primary Metals Industries .... 4.2 
L.2 Projection of Product Mix in U.S. Steel Production, $1976-2000$

4.3 Energy Services and Major Processes in the Iron and Steel Industry ...................................... 4.6

L.4 Fuel Use and Energy-Related Trends in the Steel Industry ...... 4.7

L.5 Typical Yields and Electrical Energy Consumption of Hot Rolling Processes

L.6 Direct and Indirect Energy Losses Analyzed in the Iron and

4.7 Tribological Mechanisms in the Iron and Steel Industry ........ 4.22

5.1 Purchased Energy Consumption in the Chemical and Petroleum Refining Industries

5.2 Purchased Energy Consumption by Fuel Type in the Chemical and Refining Industries

5.3 Electricity Consumption in the Chemical and Petroleum Refining Industries ................................. 5.4

5.4 Top 50 Chemical Products in $1983 \ldots \ldots \ldots \ldots \ldots \ldots \ldots \ldots \ldots \ldots \ldots . \ldots \ldots . \ldots \ldots$

5.5 Chemical Processes in the Drexel Data Base $\ldots \ldots \ldots \ldots \ldots \ldots \ldots \ldots .5 .6$

5.6 Loss Mechanisms in the Chemical and Petroleum Refining Industries

5.7 0irect Tribological Losses in the Chemical and Petroleum Refining Industries ................................ 5.16

6.1 Purchased Fuels and Electric Energy in Pulp and Paper ......... 6.2

6.2 Purchased Energy Consumption by Fuel Type in the Pulp and

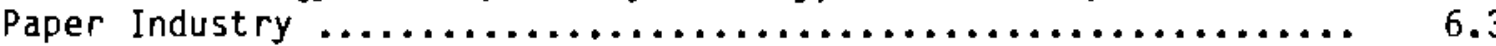

6.3 Purchased Energy Consumption by Fuel Type in Logging Camps and Logging Contractors ................................ 6.3

6.4 Purchased Energy Consumption by Fuel Type in Pulp Mills ........ 6.3

6.5 Purchased Energy Consumption by Fuel Type in Paper Mills ....... 6.4

6.6 Purchased Energy Consumption by Fuel Type in Paperboard Milis 
6.) Purchased Energy Consumption by Fuel Type In Building Paper

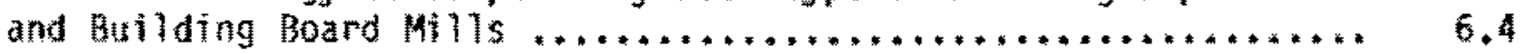

6.8 Self-generated fuels in the Pulp and paper Industry $\ldots \ldots \ldots \ldots \ldots, 6.5$

6.91980 Paper and Paperboard Production $\ldots \ldots \ldots \ldots \ldots \ldots \ldots \ldots \ldots \ldots$

6.101980 pulp Production $\ldots \ldots \ldots \ldots \ldots \ldots \ldots \ldots \ldots \ldots \ldots \ldots \ldots \ldots \ldots \ldots \ldots \ldots$

6.11 Amual Direct and Indirect Losses in Tree Harvesting .*...***** 6.13

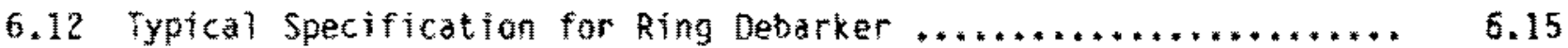

6.13 Direct and Indirect Tribological Losses in Mechanical

Debarking ........................................

6.14 Weight, Size and Replacement Frequency for Chipper Components ... 6.17

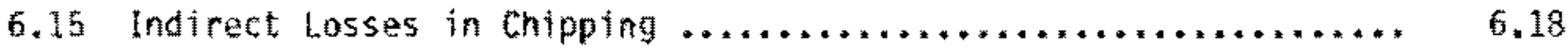

6.16 Direct and Indirect Losses of Stone Groundwood Pulp

Production

6.27 Direct and Indirect Tribological Losses of chip Groundwood production

6.13 Direct and Indirect Losses During Secondary Defibering ........ 6.24

6.19 Genertc Tribological Loss Mechanisms in Pulp and Paper ........ 6.24

6.20 Annual Direct Tribological Energy Losses in Pulp and Paper **** 6.25

6.21 Annual Indirect Trobological Energy Losses in Pulp and Paper .... 6.25

7.1 Energy Consumption by Fuel Type in the Food Processing industry

7.2 Energy Consumption Within the Major Food Processing Industry

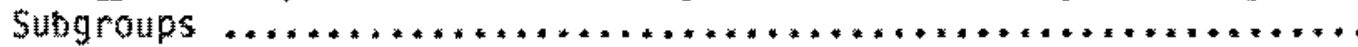

7.3 Top Ten Energy-Consuming Food Processing Industries at the 4-bigit SIC Level $\ldots \ldots \ldots \ldots \ldots \ldots \ldots \ldots \ldots \ldots \ldots \ldots \ldots \ldots \ldots \ldots \ldots \ldots \ldots \ldots \ldots \ldots \ldots 7,3$

7.4 Major Product classes within the Food Processing Industry ...... 7.4

7.5 Food Processing 0perational Activities $\ldots \ldots \ldots \ldots \ldots \ldots \ldots \ldots \ldots$

7.6 Estimated Direct Tribological Losses from Conveyors in Selected Food Industries 
7.7 Cossette Knife Replacement and Sugar Beet Production, 1983

Summary for Four Plants .......................... 7.12

7.8 Generic Tribological Loss Mechanisms in Food Processing ........ 7.14

7.9 Annual Direct Tribological Energy Loss in Food Processing ...... 7.14

'.10 Annual Indirect Tribological Energy Losses in Food

Processing ......................................... 7.14 



\subsection{INTROOUCTION}

Tribology is the science of friction and wear of materials that move in contact with other materials. This report describes a preliminary review of tribology's impact in six major industries in the United States. In each of the six industries, the research identified processes where tribology was present and characterized the nature and magnitude of the assoclated energy losses and material wear.

\subsection{BACKGROUND}

Tribology occurs in all industrial processes and results in direct energy consumption and the wear of machines and materlals. Finding better lubricants and wear-reststant naterials to reduce these energy and material losses and to encourage more productive industry is the goal of the Tribology Progran within the 1.5. Department of Energy (DoE). The Energy Conversion and Uthlization Techology (ECUT) Program office within IoE is responsible for the multiyear progmam. The purpose of this research is to identify the location and importance of tribological losses in the industrial sector to provide backgraund information to ECUT staff as they jentify and prioritize generic researh opportunities in tribology.

Previous research in laentifying tribological sinks has been very general. For example, the American society of Mechanical Engineers (AsME) conducted a tribology review (Pinkus and Wllcox 1977), but the study was very cursory because of the recognized complexity of the problem. A more detatled review was needed to identify 1) which industries had the most significant tribological sinks, 2) how much energy and naterial loss was attributed to these sinks, and 3 ) what generic types of tribology mechanisms were involyed.

\subsection{APPROACH}

Initially, the primary goal of the review of tribology sinks was to conduct a preliminary review of major industries to locate and describe the nature c tribology sinks in those industries. The industries selected for possible inclustion in the study were as follows: 
- Agriculture

- Mifling

- Transportation Equipment

- Pabricated Metals

- Primary Metals

- Pulp and Paper

- Stone, Clay, and Glass

- Textiles

- Chemicals/Petroleun Refining.

In the first task of the review, the major processes in each industry were identifled to estirate the location of major tribological sinks. The results, shown in Table 1.1, indicate that inportant tribological activities occur in a) industries and in most najor processes within each industry.

Detalled characterization of each tribological sink in the industries listed tin Table 1.1 would have exceeded both the resources and tine constraints initially allocated for the research. Therefore, the research approach was redefined to achieve the project goals within the time and furding constraints. A strategy for selecting and evaluating a smaller set of industries that appeared to have the greatest tribology sinks was pursued. The resulting strategy was selected because it narrowed the candidate industries to the six that appeared to have the most tribological activity, which allowed each individual industry to be more thoroughly exanined.

The initial list of industry groups and the associated processes was reviewed by the staff at Pacific Northwest Laboratory (PN). and BattelleColumbus Laboratories (BCL) to select the five or six groups that appeared to have the most significant tribological sinks. The criteria for selecting this final set of industries included the presence of 1) major nonthermal energy streams such as machine drives, 2) high material wear rates/friction, and 3 ) material transportation/alteration processes.

In selecting the final set of industries, energy use in those industries was first reviewed. Figure 1.1 shows the energy-use data reviewed and ind cates those industries having the largest energy use. For each of the top 
TABLE 1.1. Candidate Industrial Process Categories

AGRICULTURE

Preplant/Plant/Cultivation

Harvest

Irrigation

Grain/Feed Handling

HVAC

\section{MINING}

Mining

- Drilling

Crushing

Grinding and Classifying

Beneficiation

Pelletizing

TRANSPORTATION EQUIPMENT

Hot Working

Fabrication

Plastics Production

FABRICATED METALS

Forge

Cast

Cold Form

Machine

Heat Treating

Finishing

Joining

Assembly

\section{PRIMARY METALS}

Casting

- Continuous Casting

Milling

- Hot Strip

- Plate

Welding

Drawing
PULP AND PAPER

Debarking

Chipping

Pulping

- Refiner mechanical

- Groundwood mechanical

Mechanical Drying

STONE, CLAY AND GLASS

Crushing

Blending

Grinding

Kiln

- Material Handling

Cooling Fan

Polishing Glass

\section{TEXTILES}

Spinning

Texturizing

Weaving

Knitting

Finishing

CHEMICALS/PETROLEUM REFINING

Pumping

Compressing

Mixing

Agitating

Crushing

Extruding 
industry groups, a breakdown of energy consumption by end use was then reviewed to identify the processes having the highest direct machine energy use. These results were reviewed by $\mathrm{BCL}$ staff members to obtain their recommendations based upon experience and industry contacts. The final set of industries chosen for the analysis is as follows:

- Mining

- Primary Metals

- Agriculture

- Chemicals/Petroleum Refining

- Food Processing

- Pulp and Paper Products.

GROUP TOTAL

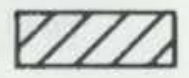

MACH. DRIVE

$\infty \times$

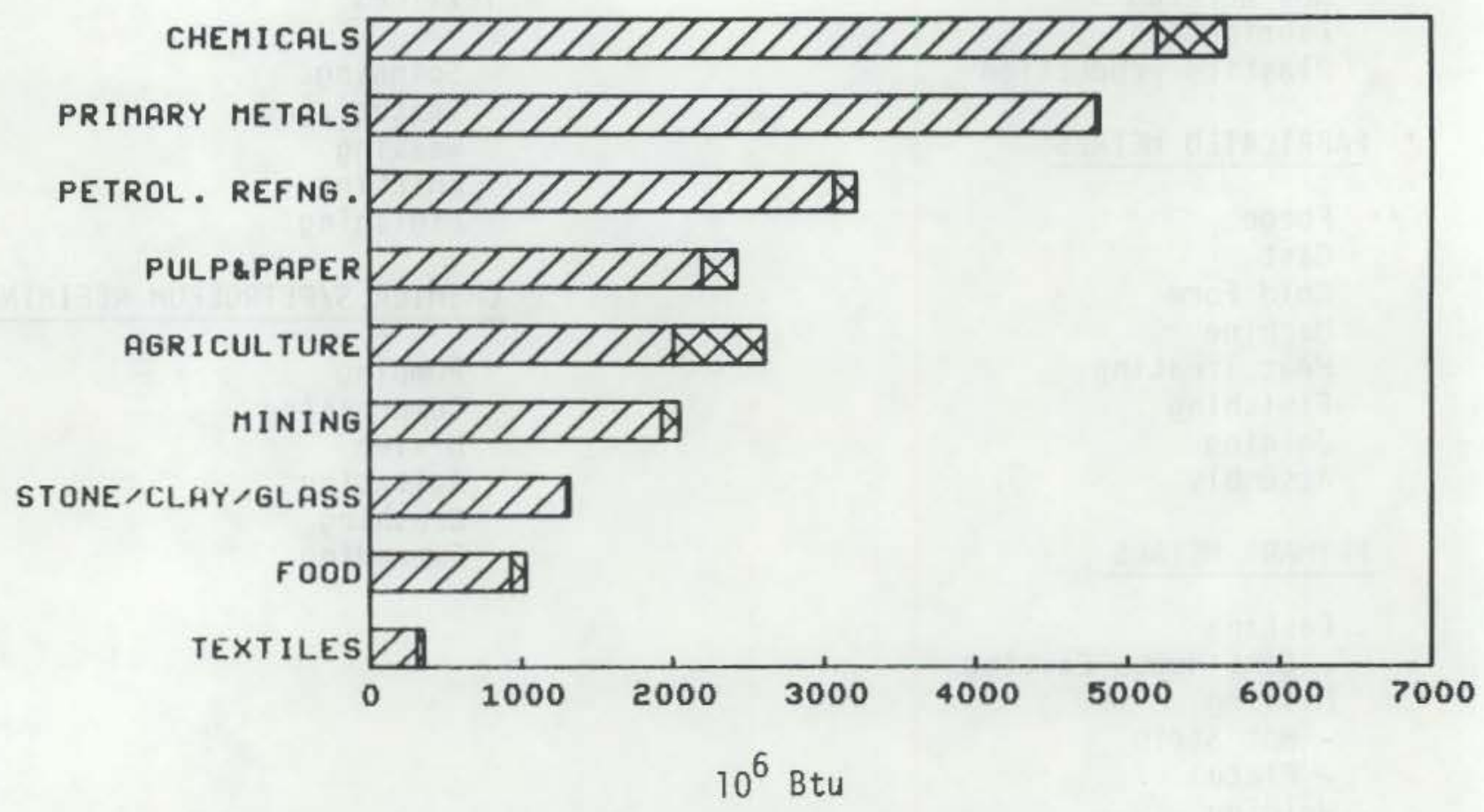

FIGURE 1.1. Energy Use in the Industries Selected for Analysis

Mining was selected more for the high material wear rates and the large number of tribology sinks than for total energy use. The Primary Metals industries were included because they consume large quantities of energy and raw 
materials, and significant tribology sinks are involved in forming and processing the metals. The Agriculture sector was included because of the large number of tribology sinks and the significant energy use and material wear rates involved in tilling and transport systems. The Chemicals industry was selected because of the high energy use and the significant presence of machine drive for pumping, mixing, etc. Food Processing and the Pulp and Paper industries were chosen because they both had significant energy consumption rates and tribological sinks, particularly in the materials handling processes.

By focusing on the set of industries having the most potential for decreasing energy losses and material wear, each industry could be reviewed in enough detail to characterize the major sinks; any reviews of additional groups could be added later if the research identified other important areas for funding next year.

After the final set of six industries was selected, the tribologic sink review was divided between $\mathrm{PNL}$ and $\mathrm{BCL}$ according to Figure 1.2. $\mathrm{BCL}$ was responsible for describing the technical nature of each major tribological sink in each industry, and PNL was responsible for determining the direct and indirect energy impacts in each sink.

BCL's technical analysis started with PNL's surmary of energy use in a specific industry group. These main energy streams were identified to identify the major energy-dependent processes in the group. BCL reviewed these and other processes to identify those that contained significant tribological activities. To identify those processes, BCL used 1) reviews of technical process literature, 2) previous research experience, 3 ) telephone contacts with industry, and 4) expert judgment to select the major tribological sinks in the group. After selecting the candidate sinks, BCL characterized the technical nature of the sinks.

The purpose of the sink characterization was to define the type of tribological mechanism(s) active in the sink and to estimate the tribological inefficiency of the sink. The tribological inefficiency was defined as a) the 
BCL - Technical

Tribology Loss Factors

(Direct and Indirect)

Percent of Stock

Affected

Current Service

Life

Current Embodied

Materials

Equipment Turnover* or Retrofitability*

Fuel Switching*

Capability
PNL - Data

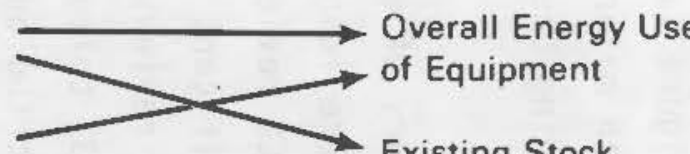

Existing Stock of Equipment

Raw Material

in Equipment

Energy to Produce

Raw Material

Service Life

Energy Use by Fuel Type
PNL - Impacts

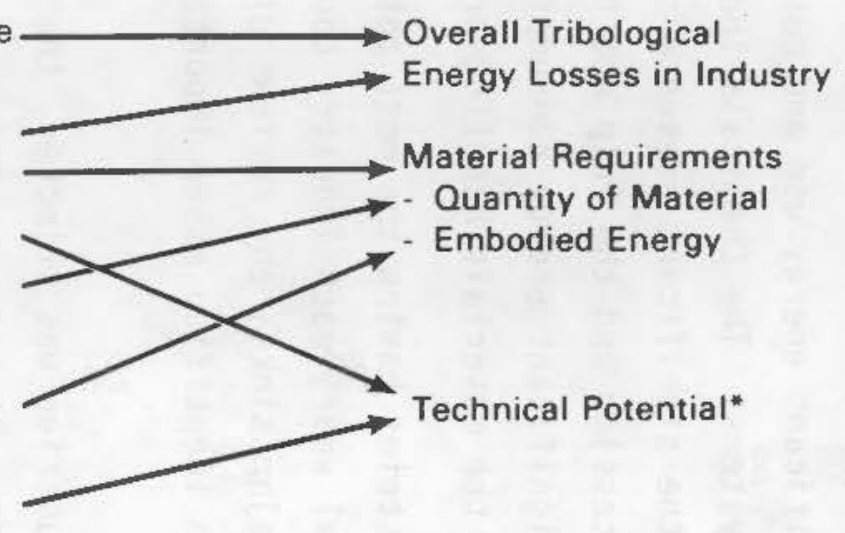

Change in Fuel Mix*

"Means "defer until FY85"

\author{
FIGURE 1.2. Revised Information Flow Diagram
}


amount of energy lost to tribology (direct energy loss) and b) the amount of embodied energy lost to tribology (indirect energy loss due to material wear). These results were usually expressed as Btu/unit of service in the sink or as amount of material lost/unit of service provided.

An example of energy loss from tribological activities is soil tillage in agriculture. Direct energy loss stems from the portion of tractor power needed to pull the tool (i.e., plow, etc.) through the soil. Typically, $30 \%$ to $60 \%$ of the draft (pull) power is attributed to this activity. The direct loss would be estimated as energy needed per acre plowed. The total direct energy loss is then computed by including total annual tillage. The indirect losses stem from the need to replace plowshares as a result of soil abrasion. For example, the plowshares are worn at an average rate per acre plowed. Using the data of total acreage plowed, the total number of plowshares replaced annually can be estimated. This figure can be converted to annual indirect energy loss by estimating the embodied energy in these discarded plowshares.

\subsection{CHAPTER CONTENTS}

This report is divided into six chapters that separately discuss the tribological sinks in each of the six industry groups. Each chapter begins with a brief discussion of the energy consumed, the fuels used, and the primary products and processes of that industry. Then, the energy use in that industry is presented by end use and energy type. This introductory information is followed by discussions of the tribological sinks identified in the industry. For each tribology sink, the discussion includes the following:

- the tribological mechanisms

- the direct tribological inefficiency and energy loss estimates

- the indirect tribological inefficiency and energy loss equivalents.

Each chapter concludes with a brief overview of the nature and impact of the tribological activities within that group. 


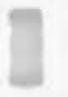<smiles>C1CCCC1</smiles><smiles>C1=CCCC1</smiles><smiles>C1CCCCC1</smiles><smiles>C1CCCC1</smiles> 


\subsection{MINING}

This chapter identifies and characterizes total energy use and tribological losses in the mining industry. Energy consumption is specified by fuel type for each of the major mining sectors (metals, coal, oil and gas, and nonmetals), and total energy consumption is compared to purchased fuels and electricity. The major processes and products of the mining industry are also briefly described, and those processes identified as having significant tribological losses are reviewed and described in more detail. The nature of each tribological sink and the mechanisms leading to direct and/or indirect energy losses are then characterized. Finally, the direct and indirect energy losses are estimated and the approach used to calculate those losses is identified. The chapter ends with a summary of the tribological losses estimated for mining.

\subsection{INTRODUCTION}

The mining industry, as defined by the 1972 Standard Industrial Classification (SIC) Manual, includes businesses that extract naturally occurring minerals as their primary activity. The major subdivisions of mining are metal mining (SIC 10), anthracite mining (SIC 11), bituminous coal and lignite mining (SIC 12), oil and gas extraction (SIC 13), and nonmetallic minerals, except fuels (SIC 14). Each of these subdivisions is broken into individual product and service categories such as iron ore, oil and gas field services, and crushed and broken limestone. Mining involves various activities that include geological mapping, drilling, quarrying, crushing, grinding, washing, loading, and transporting.

\subsubsection{Energy Consumption in Mining}

Total energy consumption in mining was $\sim 2.4$ quads in 1977, according to data presented in the 1977 Census of Mineral Industries (U.S. Census Bureau 1981. (As of May 1984, the 1977 data are the latest comprehensive energy consumption information available from the U.S. Census Bureau.) $0 i 1$ and gas extraction accounted for nearly three-fourths of this total, whereas anthracite mining represented the smallest $(0.1 \%)$ portion. Total energy consumption for 
each of the major two-digit classifications is shown in Table 2.1. The energy consumption data listed in Table 2.1 and in the following tables in this chapter have been derived from the 1977 Census of Mineral Industries (U.S. Census Bureau 1981).

Natural gas comprised about two-thirds of the energy consumed in mining. This figure is skewed, however, by the large proportion of natural gas consumption in oil and gas extraction, the dominant energy-consuming subdivision. Fuel oils are the dominant energy form in both of the coal mining categories; other significant fuel types are electricity, coal, and gasoline, in descending order of total consumption. Energy consumption data by fuel types are presented in Tables 2.2 through 2.7 for the total mining industry and each of its major subdivisions.

TABLE 2.1. Energy Consumption in Mining (1977)

\begin{tabular}{|c|c|c|c|}
\hline SIC \# & Classification Name & $10^{12} \mathrm{Btu}$ & $\%$ of Total \\
\hline 10 & Metal Mining & 165 & 6.9 \\
\hline 11 & Anthracite Mining & 3 & 0.1 \\
\hline 12 & $\begin{array}{l}\text { Bituminous Coal and } \\
\text { Lignite Mining }\end{array}$ & 126 & 5.3 \\
\hline 13 & 0 il and Gas Extraction & 1774 & 74.2 \\
\hline \multirow[t]{2}{*}{14} & $\begin{array}{l}\text { Nonmetallic Minerals, } \\
\text { Except Fuels }\end{array}$ & 323 & 13.5 \\
\hline & Total & 2391 & 100.0 \\
\hline
\end{tabular}

TABLE 2.2. Energy Consumption by Fuel Type in the Mining Industry (1977)

\begin{tabular}{lrrrr}
\multicolumn{1}{c}{ Fuel } & & $10^{12}$ Btu & & \% of Total \\
Coal & & & & 2.6 \\
Fuel 0il & & 364 & & 15.2 \\
Natural Gas & & 1614 & & 67.6 \\
Gasoline & & 44 & & 1.8 \\
Electricity & & 203 & & 8.5 \\
Other & & 102 & & 4.3 \\
Total & & 2390 & & 100.0
\end{tabular}


TABLE 2.3. Energy Consumption by Fuel Type in Metal Mining (1977)

\begin{tabular}{lrrrr}
\multicolumn{1}{c}{ Fuel } & & $10^{12}$ Btu & & \% of Total \\
Coal & 12 & & 7.3 \\
Fuel Dil & 42 & & 25.3 \\
Natural Gas & 59 & & 35.4 \\
Gasoline & 2 & & 1.5 \\
Electricity & 50 & & 30.5 \\
Total & & 165 & & 100.0
\end{tabular}

TABLE 2.4. Energy Consumption by Fuel Type in Anthracite Mining (1977)

$\begin{array}{lcccc}\frac{\text { Fuel }}{\text { Fuel 0il }} & & \frac{10^{12} \mathrm{Btu}}{} & & \text { \% of Total } \\ \text { Natural Gas } & & 0.0 & & 37.3 \\ \text { Gasoline } & & .23 & & 7.0 \\ \text { Electricity } & .68 & & 22.7 \\ \text { Coal and Other } & .97 & & 32.3 \\ \text { Total } & & 3.00 & & 100.0\end{array}$

TABLE 2.5. Energy Consumption by Fuel Type in Bituminous Coal and Lignite Mining (1977)

\begin{tabular}{lrrrr}
\multicolumn{1}{c}{ Fuel } & & $10^{12}$ Btu & & $\%$ of Total \\
Fuel 0il & & 60.7 & & 48.0 \\
Natural Gas & & 1.7 & & 1.4 \\
Gasoline & & 7.7 & & 6.1 \\
Electricity & & 34.6 & & 27.4 \\
Coal and 0ther & 21.6 & & 17.1 \\
Total & & 126.3 & & 100.0
\end{tabular}

Energy consumption data are also provided in the 1977 Census of Mineral Industries for purchased fuels and electric energy, which is a subset of the total energy consumption data presented above. Purchased energy represents less than half of the total energy consumption in the minerals industry 
TABLE 2.6. Energy Consumption by Fuel Type in 0 il and Gas Extraction (1977)

\begin{tabular}{|c|c|c|}
\hline Fuel & $10^{12} \mathrm{Btu}$ & $\%$ of Total \\
\hline Fuel 0 il & 201 & 11.3 \\
\hline Natural Gas & 1411 & 79.6 \\
\hline Gasoline & 28 & 1.6 \\
\hline Electricity & 78 & 4.4 \\
\hline Coal & 0 & 0.0 \\
\hline Others & 56 & 3.1 \\
\hline Total & 1774 & 100.0 \\
\hline
\end{tabular}

TABLE 2.7. Energy Consumption by Fuel Type in Nonmetallic Minerals, Except Fuels (1977)

\begin{tabular}{|c|c|c|}
\hline Fuel & $10^{12}$ Btu & \% of Total \\
\hline Fuel oils & 59 & 18.3 \\
\hline Natural gas & 142 & 43.9 \\
\hline Gasoline & 6 & 1.7 \\
\hline Electricity & 37 & 11.6 \\
\hline Coal & 38 & 11.8 \\
\hline Others & 41 & 12.7 \\
\hline Total & 323 & 100.0 \\
\hline
\end{tabular}

( 1.1 quad versus 2.4 quad). The difference primarily occurs in the oil and gas extraction sector, where 1.29 quad of energy consumption are nonpurchased; that is, they are produced and consumed on the premises. When only purchased fuels and energy are considered, the relative amounts of energy consumed in each of the mining sectors become more even, as shown in Table 2.8 .

The mining industry produces many ore and mineral products, but when each product's importance is measured by factors such as number of establishments, value added, employees, and energy consumption, the list shrinks to a manageable number. The principal products that consume more than $10 \times 10^{12} \mathrm{Btu}$ during the mining process are identified in Table 2.9. 
TABLE 2.8. Purchased Fuels and Electric Energy in the Mining Industry (1977)

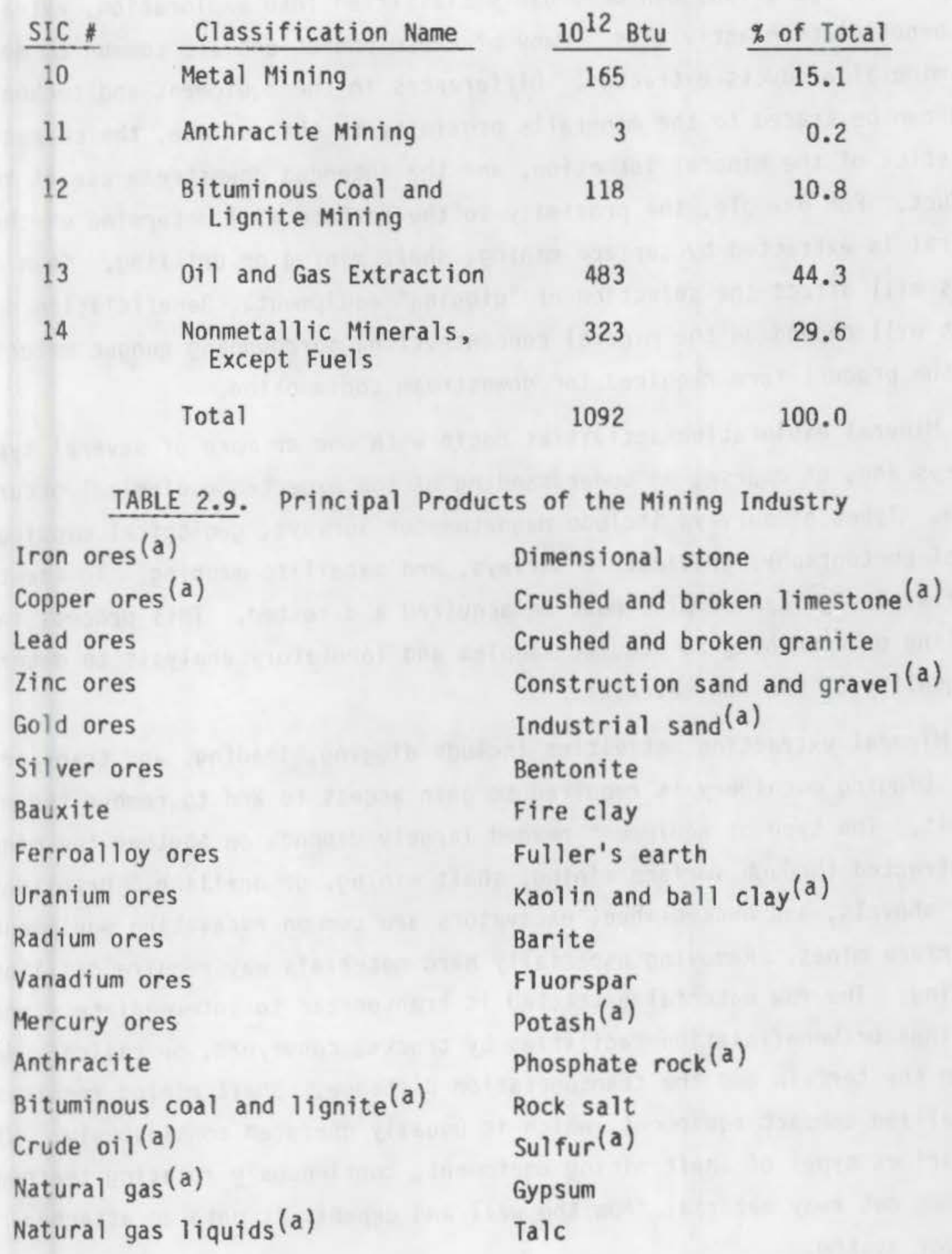

(a) These products consume over $10 \times 10^{12}$ Btu/yr during the mining process. 


\subsubsection{Mining Operation Activities}

Mining operations can be broadly classified into exploration, extraction, and beneficiation activities. Many of these operations are common to most of the mineral products extracted. Differences in the equipment and technology used can be traced to the mineral's proximity to the surface, the characteristics of the mineral formation, and the intended downstream use of the product. For example, the proximity to the surface will determine whether the mineral is extracted by surface mining, shaft mining or drilling. Seam dimensions will affect the selection of "digging" equipment. Beneficiation operations will depend on the mineral concentration, surrounding gangue material, and the product form required for downstream consumption.

Mineral exploration activities begin with one or more of several types of surveys and, of course, an understanding of the expected geological occurrence. Types of surveys include magnetometer surveys, geological mapping, aerial photography, gravimetric surveys, and satellite mapping. To identify materials, physical samples must be acquired and tested. This process involves drilling or trenching to acquire samples and laboratory analysis to determine the quality of the raw material.

Mineral extraction activities include digging, loading, and transporting. Digging machinery is required to gain access to and to remove the mineral deposit. The type of equipment needed largely depends on whether the mineral is extracted through surface mining, shaft mining, or drilling. Draglines, power shovels, and bucket-wheel excavators are common excavating equipment used in surface mines. Removing especially hard materials may require drilling or blasting. The raw material extracted is transported to intermediate storage locations or beneficiation facilities by trucks, conveyors, or railcar, depending on the terrain and the transportation distance. Shaft mining requires specialized compact equipment, which is usually operated continuously. With the various types of shaft mining equipment, continuously rotating teethed surfaces cut away material from the wall and deposit it onto an attached conveyor system.

Beneficiation includes activities that increase the concentration of the desired mineral or improve its form. Typical beneficiating activities include 
grinding, screening, washing, and flotation. Gravitational and magnetic forces are also used to separate materials. Some ores may be leached with acids if physical separation techniques are impractical.

\subsection{MINING OF METALLIC ORES, COAL, AND NONMETALLIC MINERALS}

The two major methods for extracting ores, minerals, and coal are surface mining and shaft mining. The equipment used in these two types of mining have distinct differences. However, five common process steps are used in both:

- exposing (removing overburden)

- digging

- loading

- transporting

- ore processing.

In the following sections, the tribological energy losses from these processes in surface mining and shaft mining are described. In each section, the mining method is described and tribological losses for components that are major sinks in that area are summarized. The subsequent subsections will then present the assumptions and some of the supporting data used to calculate the direct and indirect energy losses.

\subsubsection{Surface Mining}

A representative surface mining operation(a) is shown in Figure 2.1. Examining an example surface mine will indicate how many of each equipment type is typically used. For example, at the Colowyo Coal Mine in Colorado, the equipment fleet consists of 77 major units and moves 31.5 million cubic yards of rock to mine 4.3 million tons of coal per year (Coal Age 1982). Colowyo's equipment can be broken down into the three categories:

- 4 diggers: 2 draglines, 2 power shovels

- 52 trucks: 3 water, 6 drills, 2 highway, 16 tractors and trailers, 25 haulage

(a) 26th Quarterly Publication, July 1982, Common Surface Equipment Troubleshooting Note, Published by Common Surface Mining Equipment Troubleshooting. 


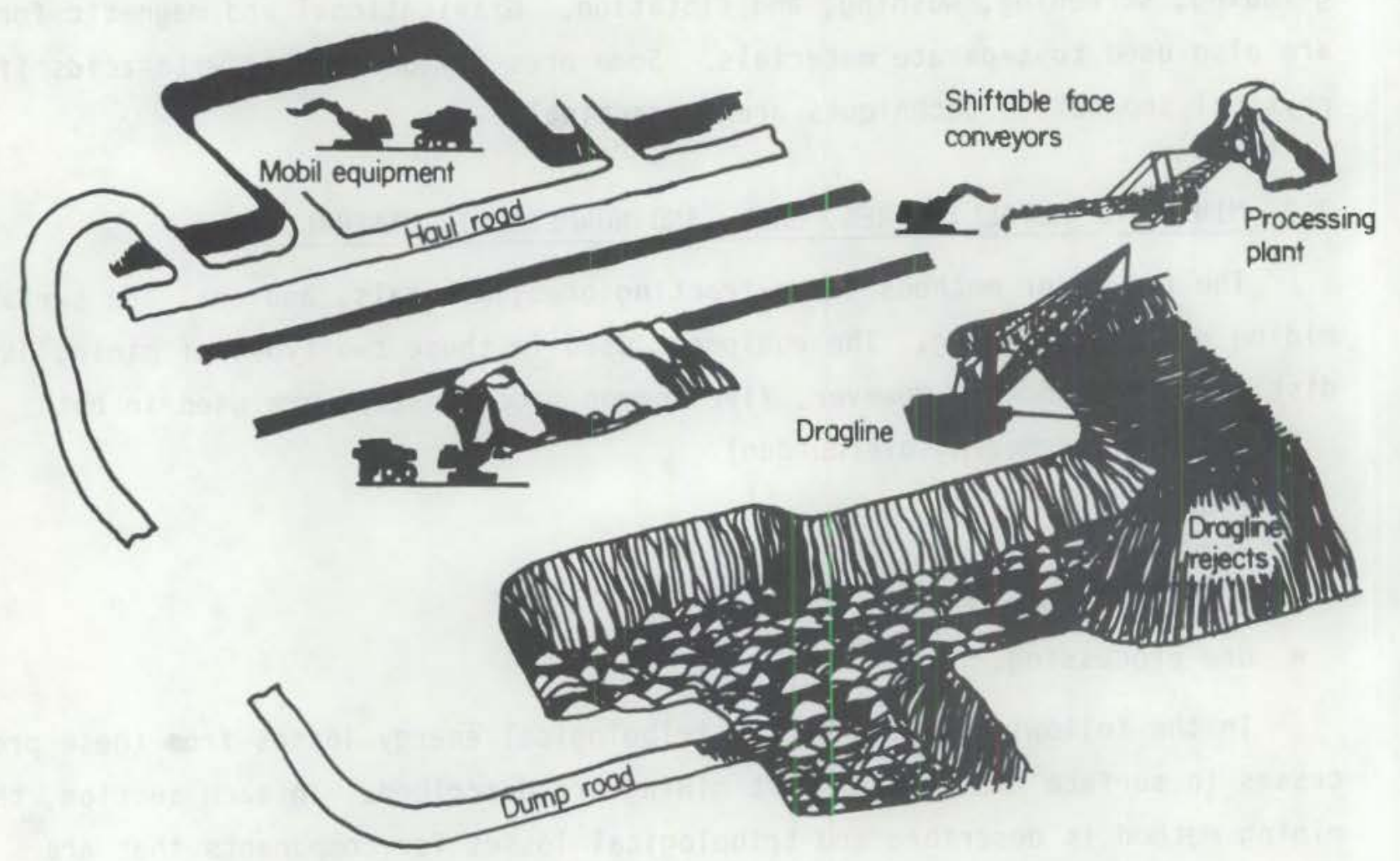

FIGURE 2.1. A Typical Surface Mining Operation(a)

(a) 26th Quarterly Publication, July 1982, Common Surface Equipment

Troubleshooting Note, Published by Common Surface Mining Equipment Troubleshooting.

- 21 loaders: 9 front-end loaders, 1 backhoe, 1 scraper, 3 graders, 7 dozers.

Estimates of the tribological energy losses for each of these types of equipment are presented in the following sections, according to the process steps. Exposing and Digging

The mining of most materials requires that some type of overburden first be removed (exposing). The overburden may be as slight as a few feet of earth or may be as troublesome as a solid vein of rock. Overburden removal is handled in surface mining by three main types of equipment: the dragline, the power shovel, and the bucket-wheel excavator, all shown in Figure 2.2. Although the operating principles of the three are very different, they share 


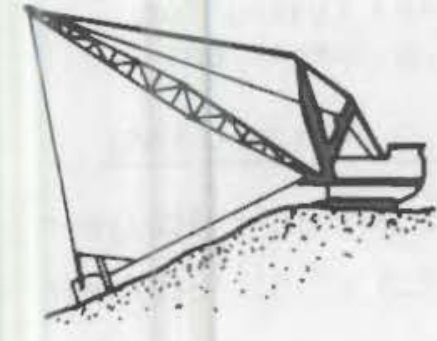

Dragline

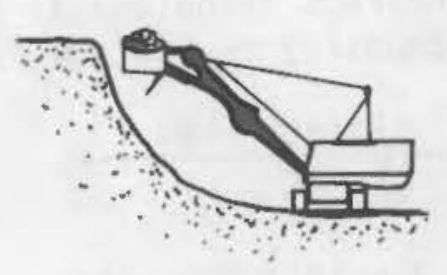

Power Shovel

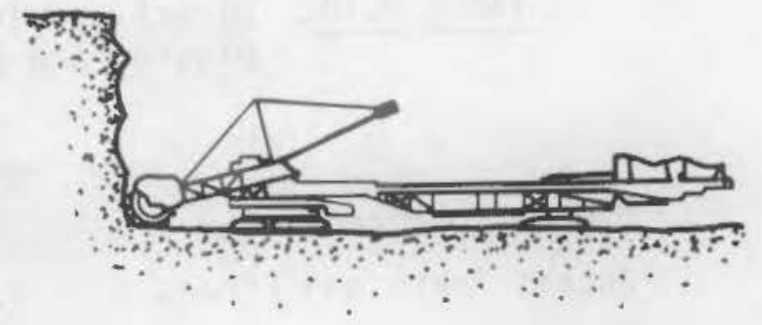

Bucket-Wheel Excavator

FIGURE 2.2. Surface Mining Exposing and Digging Equipment

several common components that comprise tribological energy losses. These types of losses are also common to digging equipment. In surface mining, once the overburden is removed, the material is harvested in much the same manner as it was exposed. The company may switch from a dragline used to remove overburden to several smaller power shovels to work out the vein, but the tribological energy losses will be similar. The components that comprise the main tribological energy losses for the dragline, the power shovel, and the bucketwheel excavator are digger lubricant, bucket teeth and liners, carry-back (material stuck in the buckets of the diggers after dumping), and wire rope. These components are listed in Table 2.10 with their associated losses.

The direct energy losses were calculated as a percent of the total energy used by a digger. In arriving at the total energy consumption per cubic yard for a digger, the following four assumptions were made:

1. Bucket-wheel excavators may be discounted.

2. Direct loss mechanisms for the power shovel are similar to dragline direct loss mechanisms.

3. A dragline will operate at $90 \%$ of the capacity of a power shovel of the same bucket size.

4. Digger production rates and power consumptions may be scaled to bucket capacity.

Bucket-wheel excavators are being discounted because they represent such a small percent of the diggers (1\%) (Watwood 1983). The assumptions on the production rates and power consumptions of the shovels and diggers were made by 
TABLE 2.10. Direct and Indirect Tribological Energy Losses for Digging and Exposing in Surface Mining Operations

\begin{tabular}{|c|c|c|}
\hline & Direct Loss & Indirect Loss \\
\hline Digger Lubricant & -- & $2.9 \times 10^{11} \mathrm{Btu} /$ year \\
\hline Bucket Teeth and Liners & $3.7 \times 10^{11} \mathrm{Btu} /$ year & $2.5 \times 10^{11} \mathrm{Btu} /$ year \\
\hline Carry-Back & $4.6 \times 10^{12} \mathrm{Btu} /$ year & -- \\
\hline Wire Rope & Small & $7.0 \times 10^{11} \mathrm{Btu} /$ year \\
\hline
\end{tabular}

comparing production data from Pfleider (1968), Cummins and Given (1973), and from two of the major manufacturers, Bucyrus-Erie and Marion Power. Based on these assumptions, the power requirement was estimated at 3400 to $5800 \mathrm{Btu} /$ cubic yard moved for electric power machinery. Error on this figure may be +50\% because it encompasses all large machinery and materials mined.

The number of tons of various materials moved yearly in the U.S. is given in Table 2.11. The total tonnage of materials moved annually in the U.S. can be converted to $8.0 \times 10^{9}$ cubic yards by using 1.4 tons/cubic yard (which was computed using a weighted average of densities of materials from Table 2.11). When multiplied by $5800 \mathrm{Btu} /$ cubic yard, this yields $4.6 \times 10^{13} \mathrm{Btu} /$ year total power consumed by the "diggers" alone in all U.S. mining.

The lubricant loss is based upon information taken from the current $\operatorname{COSMET}^{(a)}$ directory (Watwood 1983), which accounts for more than $90 \%$ of largemining machinery in use in the U.S. A list of large-mining machines in operation is given below:

- 384 draglines (primarily greater than $30 \mathrm{cu}$ yd buckets)

- 123 power shovels (as small as $5 \mathrm{cu}$ yd)

- $\sim 5$ bucket wheel excavators.

The approximate amount of lubricant used by draglines, as provided by Marion Power Shovel, Marion, Ohio, is shown in Table 2.12.

(a) "COSMET" stands for Common Surface Mining Equipment Troubleshooting and is an association concerned with surface mining problems. 
TABLE 2.11. U.S. Production of Principal Minerals from Surface Mines (1981)

\begin{tabular}{|c|c|c|c|}
\hline & $\begin{array}{c}\text { Approximate Ratio } \\
\text { of Overburden } \\
\text { to Ore } \\
\end{array}$ & $\begin{array}{c}\text { Short Tons of } \\
\text { Ore Mined } \\
\text { Per Year } \\
\end{array}$ & $\begin{array}{c}\text { Short Tons of } \\
\text { Overburden Mined } \\
\text { Per Year }\end{array}$ \\
\hline Coal & $13: 1$ & $504 \times 10^{6}$ & $6550 \times 10^{6}$ \\
\hline Copper & $2.5: 1$ & $271 \times 10^{6}$ & $678 \times 10^{6}$ \\
\hline Iron & $1: 1$ & $241 \times 10^{6}$ & $241 \times 10^{6}$ \\
\hline $\begin{array}{l}\text { Crushed and } \\
\text { Broken Stone }\end{array}$ & $0.5: 1$ & $873 \times 10^{6}$ & $436 \times 10^{6}$ \\
\hline Sand and Gravel & $0.5: 1$ & $755 \times 10^{6}$ & $378 \times 10^{6}$ \\
\hline Clay (all types) & $1.7: 1$ & $45 \times 10^{6}$ & $76 \times 10^{6}$ \\
\hline $\begin{array}{r}\text { Phosphate Rock } \\
\text { Total }\end{array}$ & $1.25: 1$ & $\begin{array}{l}59 \times 10^{6} \\
2.75 \times 10^{9}\end{array}$ & $\begin{array}{l}74 \times 10^{6} \\
8.43 \times 10^{9}\end{array}$ \\
\hline
\end{tabular}

TABLE 2.12. Yearly Lubricant Used by Oraglines (gallons)

\begin{tabular}{lcc} 
& \multicolumn{2}{c}{ Bucket Size } \\
\cline { 2 - 3 } Multipurpose grease & $\frac{300 \mathrm{cu} \text { yd }}{2,000}$ & $\frac{150 \mathrm{cu} \text { yd }}{3,000}$ \\
Open-gear grease & 300 & 1,750 \\
Wire rope lubricant & 650 & 600 \\
Gear case oil & -- & 3,500 \\
Walking cam lubricant (on & & 3,250 \\
machines $>40$ cu yd) & 3,850 & 12,100
\end{tabular}


The lubricant consumptions in Table 2.12 agreed with one mine manager's general estimate of 4000 to 6000 gallons/year for a walking dragline. (a) Assuming 4000 gallons/year for 507 large-mining machines (both draglines and power shovels), the consumption is about $2 \times 10^{6}$ gallons/year or $2.9 \times 10^{11}$ Btu/year.

The direct power loss in a dragline or power shovel bucket has been estimated using a Bucyrus-Erie Model 1260-W Dragline as an example. The following is a list of standard operating parameters for this equipment:

- Rated Bucket Size: 35 cubic yards

- Actual Bucket Size: 39 cubic yards

- Empty Bucket Weight: 71,000 pounds

- Loaded Bucket Weight: 176,000 pounds (at $100 \mathrm{lb} / \mathrm{cu}$ yd)

- Drag Speed: $1 \mathrm{ft} / \mathrm{sec}$

- Friction coefficient for steel on "Earth:" 0.2

- Bank Slope: $40^{\circ}$.

The power consumed by bucket-to-burden friction is 66 horsepower, which is 9\% of the drag motor power of 1000 horsepower (at 75\% capacity). The drag motors operate for $\sim 40 \%$ of the total fill, swing, and dump cycle. The bucket friction then amounts to $0.8 \%$ of total dragline power consumption or $3.7 \times 10^{11}$ Btu/year lost to bucket friction, as shown in Table 2.10.

Loss of bucket teeth and liners from abrasive wear is routine in the surface mining industry. Bucket teeth and liner life is most strongly affected by the type of material being dug. The materials are classified in Table 2.13 with a scale showing the effect on replaceable teeth and wear plates (ESCO Corporation undated). The scale is highly approximate and is only included to show the high variability introduced by changing materials. However, the 6to 9-month limit at the high end of the scale was indicated consistently in conversations with field maintenance engineers and by product literature. The 15-minute blade life at the right end of the scale is observed when blades are ripping solid rock and are described as "smoking hot" from the high-abrasive

(a) Personal communication on August 16, 1983, with Wilson McMannis, Manager of Consolidation Coal Company, Pennsylvania. 
TABLE 2.13. Blade Life Under Various Digging Conditions (Pfleider 1968)

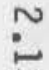

\begin{tabular}{|c|c|c|c|c|}
\hline \multirow[b]{3}{*}{$\begin{array}{l}\text { General Material } \\
\text { Description }\end{array}$} & \\
\hline & Easy Digging & Medium Digging & Kard Digging & Rock \\
\hline & $\begin{array}{l}\text { Loose, soft, free-running } \\
\text { materials } \\
\text { Close lying, which will fill } \\
\text { dipper or bucket to capa- } \\
\text { city and frequently provide } \\
\text { heaped load } \\
\text { Overload compensates for } \\
\text { swell of materials }\end{array}$ & $\begin{array}{l}\text { Harder materials that do } \\
\text { not require blasting, } \\
\text { but break up with bulki- } \\
\text { ness causing voids in } \\
\text { dipper or bucket }\end{array}$ & $\begin{array}{l}\text { Materials requiring some } \\
\text { breaking up by light } \\
\text { blasting or shaking } \\
\text { More bulky and somewhat } \\
\text { hard to penetrate, caus- } \\
\text { ing voids in dipper or } \\
\text { bucket }\end{array}$ & $\begin{array}{l}\text { Blasted rock, hardpan } \\
\text { and other bulky } \\
\text { materials, which } \\
\text { cause considerable } \\
\text { voids in dipper or } \\
\text { bucket and are diffi- } \\
\text { cult to penetrate }\end{array}$ \\
\hline $\begin{array}{l}\text { Specific Material } \\
\text { Names }\end{array}$ & $\begin{array}{l}\text { Dry sand or small gravel } \\
\text { Moist sand or small gravel } \\
\text { Loam } \\
\text { Loose earth } \\
\text { Muck } \\
\text { Sandy clay } \\
\text { Loose clay gravel } \\
\text { Cinders or ashes } \\
\text { Bituminous coal } \\
\text { Very well-blasted material }\end{array}$ & $\begin{array}{l}\text { Clay--wet or dry } \\
\text { Coarse gravel } \\
\text { Clay gravel, packed } \\
\text { Packed earth } \\
\text { Anthracite coal }\end{array}$ & $\begin{array}{l}\text { Well-broken limestone, sand } \\
\text { rock and other blasted } \\
\text { rocks } \\
\text { Blasted shale } \\
\text { Ore formation (not of rock } \\
\text { character) requiring some } \\
\text { blasting } \\
\text { Heavy wet, sticky clay } \\
\text { Gravel with large boulders } \\
\text { Heavy, wet gumbo } \\
\text { cemented gravel }\end{array}$ & $\begin{array}{l}\text { Hard tough shale } \\
\text { Limestone } \\
\text { Trap rock } \\
\text { Granite } \\
\text { Sandstone } \\
\text { Taconite } \\
\text { Conglomerate } \\
\text { Caliche rock } \\
\text { Any of these blasted to } \\
\text { large pieces mixed } \\
\text { with fines and dirt } \\
\text { Tough, rubber clay that } \\
\text { shaves from bank }\end{array}$ \\
\hline
\end{tabular}


wear energy inputs. The indirect loss estimate for bucket teeth and liners was based on replacing 14,300 pounds of steel per bucket every 6 months.

Carry-back refers to material that is stuck in the buckets of the diggers after dumping. Carry-back creates the direct loss of having to lift useless weight, as well as reduced bucket capacity, which results in proportionately additional passes to remove a fixed amount of material. The degree of carryback experienced is most strongly influenced by the type and moisture content of the material moved. Because these considerations vary with geography, U.S. maps that divided the U.S. by geology, geologic age, and mechanism of formation (Department of Interior 1970), parent soil (Marbut 1935), topsoil (Department of Interior 1970), and minerals distribution (Department of Interior 1970) were consulted. The compilation of these various classifications reduced the U.S. to five major divisions, as shown in Figure 2.3.

The geological areas can be typified as shown in Table 2.14. Each of the percentages in Figure 2.3 was based on an interview with a mine manager at

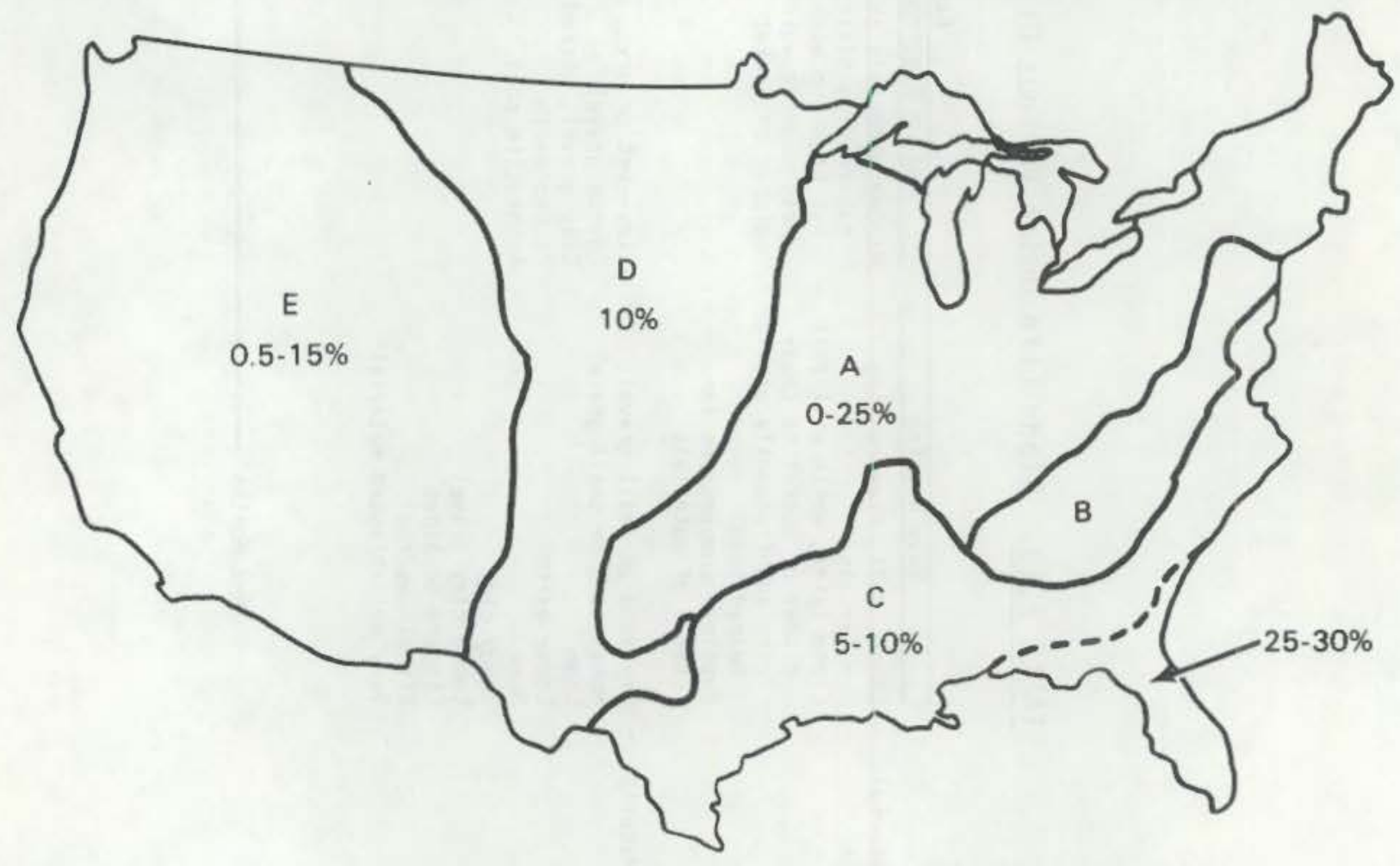

FIGURE 2.3. Percent Carry-Back in Major Geological Divisions (as indicated by mine managers) 
TABLE 2.14. Characterization of the Five Geological Divisions

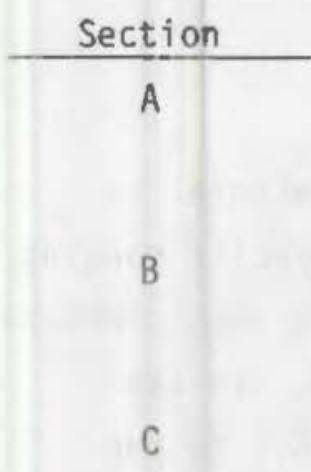

Dotted section

(Florida)

D

E

\section{Moisture Content}

Usually moist but dry part of
the time during warm
seasons

Usually moist but dry part of the time during warm seasons

Seasonably wet

Marsh

Subhumid, semidry climates

Typically dry, low in organic matter, never moist for more than 3 consecutive months
Parent Material of Soils

Limestones, sandstones, clays, shale, oil, and tar sands

Crystalline rock and granite, mica, field spar and quartz

Sands, clays, and limestones

Marine deposits, phosphate rocks

Great Plains material, deep topsoils

Alluvial fans, other desert accumulations and gravels, pumice volcanic rock

that location. Blasted rock in Region $A$ and dry sand in Region $E$ has $0 \%$ carryback. Wet clay or phosphate mining in the Florida marshlands has carry-back as high as $30 \%$. Considering these two figures, we chose $10 \%$ as a conservative estimate to use nationwide. When multiplied times the power consumption for the diggers, this yields $4.6 \times 10^{12}$ Btu/year wasted through carry-back.

The wire ropes used in the diggers for hoisting fail from fatigue or fretting fatigue. The drag ropes used only in draglines also suffer from abrasive wear. PNL has done extensive research in this area, and the estimate of the indirect loss/year from draglines was taken from a PNL study (Beeman 1978).

Summary. Carry-back was the largest direct tribological energy loss found in this study of surface mining. Various methods of reducing the coefficient of friction in the bucket are being studied. For example, because carry-back was reported as being a greater problem during cold weather, buckets are sometimes continuously heated during the winter, which is also a direct energy lass. Polymer bucket liners have been tried and found to be successful in reducing carry-back where the wear rate is not so high that the liner is 
quickly destroyed. An ideal solution would be a consistent (all-season) lowfriction liner with good wear resistance.

$\underline{\text { Loading }}$

At some point in the mining operation, almost all of the material is assumed to be handled by some type of loader having a bucket capacity ranging from 10 to 20 cubic yards. Some material will be rehandled, and some overburden handled by draglines will not be handled by a loader at all. In the Colowyo Mine example cited earlier, these loaders were present $5: 1$ to the diggers. Loaders simply load material, which has often been piled or exposed by one of the large diggers, into a truck or onto a conveyor system.

For loading equipment, tribological losses are caused from abrasive wear by the material being moved. This wear affects the carriages, tires or treads, and buckets or blades. The direct and indirect loss mechanisms for the loaders are very similar to those previously discussed for dragline and power shovel buckets. The same life expectancies and observations of Table 2.13 are applicable to a loader's teeth inserts, blade inserts for scrapers and dozers, ripper blades that break up soil, and wear plates for buckets. The 6-to-9-months' replacement used as a conservative estimate cannot be estimated any more precisely unless local material types are considered.

The following parameters were used for estimating the direct loss for a front-end loader.

- Bucket Capacity: 10 cubic yards

- Operating Speed: 2-6 mph

- Capacity: 1800 cubic yards/hour

- Blade Angle: $22^{\circ}$

- Coefficient of Friction: 0.2 .

The friction loss for the material sliding over the upper surface of the bucket or blade was estimated to be $7 \times 10^{10}$ Btu/year. Scrapers and bulldozers are also used in loading, but the percentage of material they move was assumed small in comparison to other loaders. 
Indirect losses from loading were estimated based on replacing the loader liner and teeth once every six months. The teeth and liners for a median-size bucket weigh $\sim 700$ pounds. Indirect losses of $6.1 \times 10^{10} \mathrm{Btu} /$ year were estimated.

\section{Transporting}

Transportation in mining may be divided into three main categories: trucks, conveyors, and railcars. The following general descriptions of these systems were taken from Cummins and Given (1973, pages 17-21). The principal tribological losses associated with surface transportation are summarized in Table 2.15.

Trucks are a very flexible transportation system and can climb steep ramps. However, they require good roads to minimize tire cost and are limited by economic considerations to an operating radius of about three miles. An interview with Cummins and Given (1973) indicated that trucks handle at least $70 \%$ of surface mining transportation.

Truck maintenance records at one mining operation indicated that the top 10 repair items account for $90 \%$ of those costs (Cummins and Given 1973). Six of the top 10 items may be traced to tribological failures, with tire replacement and repair representing $30 \%$ of the total operating cost.

Tire life is affected by many factors, including inflation, speeds, curves in load and dump cycle, road surface, loads, wheel position on truck, and road grade. A nominal value for the maximum life of off-the-road tires under favorable conditions was given as 6000 hours (Pfleider 1968, p. 582). An average life for front and rear tires when calculated for specific examples is

\section{TABLE 2.15. Transportation in Surface Mining}

\begin{tabular}{|c|c|c|}
\hline & Direct Loss & Indirect Loss \\
\hline Trucks & - & $1.2 \times 10^{13} \mathrm{Btu} /$ year \\
\hline Conveyors & $3.8 \times 10^{12} \mathrm{Btu} /$ year & 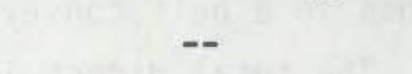 \\
\hline Railcars & -- & -- \\
\hline
\end{tabular}


3000 hours. Data taken from a survey of hauling practices (Cummins and Given 1973, pps. 17-82) at 24 copper mines were used to estimate a typical truck capacity of 30 to 100 short tons and a production rate of 800 to 2200 short tons/shift. For all types of material, this yields an estimated tire capacity of $3 \times 10^{5}$ cubic yards per tire set. If $70 \%$ of the $8 \times 10^{9}$ cubic yards per year from Table 2.11 is moved by a truck with at least 4 wheels, then surface mining will consume at least 80,000 tires per year.

Belt conveyors are economical for high-volume, long-distance hauling and can handle grades up to about $40 \%$. However, to get long belt life, conveyors must handle fairly small pieces of material, and sometimes have limited mobility. Some materials, principally sand, gravel, kaolin (clay), and phosphates, may be hydraulically conveyed. Hydraulic conveying involves pumping a slurry mixture cross-country in a pipeline. Although this method may dominate transfer of particular materials, the amounts are small when compared to the total amounts of material conveyed by conventional methods. The associated losses will therefore be discounted. Belt conveying will then be assumed to handle $20 \%$ of surface-mined materials (the remainder of materials that are not handled by trucking, with $10 \%$ left out for all other miscellaneous and railcar).

Conveyor losses are caused by many sources, such as friction in the pulleys, friction of the belt riding over the pulleys, and skirtboard friction from the conveyed material rubbing the sides of the conveyor. The amount of direct energy lost to each interface, excluding the power required to elevate the material, has been estimated by applying formulas published by the Conveyor Equipment Manufacturers Association (CEMA) (1979). The values assumed in estimating direct friction losses in conveyors in Table 2.16 were determined by examining values from mine surveys (Cummins and Given 1973) to apply the CEMA formulas for estimating direct friction losses.

Conveyors were indicated to be very advantageous for haulage distances greater than 10,000 feet. Under the assumptions given above, the direct tribological loss in a belt conveyor was $2 \times 10^{5}$ Btu/2000 tons/1000 horizontal feet conveyed. The total direct loss from conveying was calculated based on transporting $20 \%$ of all surface-mined materials an average distance of 17,000 feet. 
TABLE 2.16. Values Assumed for Estimating Direct Friction Losses in Conveyors

\begin{tabular}{|c|c|c|}
\hline Parameter & Typical Ranges & Nominal Value Used \\
\hline Belt width & $14-72$ in. & 48 in. \\
\hline Conveyed material weight & $50-150 \mathrm{lb} / \mathrm{cu} \mathrm{ft}$ & $104 \mathrm{lb} / \mathrm{cu} \mathrm{ft}$ \\
\hline Belt speed & $250-1000 \mathrm{ft} / \mathrm{min}$ & $500 \mathrm{ft} / \mathrm{min}$ \\
\hline Belt capacity & $20-8000$ tons $/ \mathrm{hr}$ & 2000 tons $/ \mathrm{hr}$ \\
\hline Distance conveyed & $30 \mathrm{ft}-30 \mathrm{mi}$ & Calculated per $1000 \mathrm{ft}$ \\
\hline
\end{tabular}

Several examples were calculated, and these losses amounted to $30 \%$ to $50 \%$ of the power required to drive a conveyor.

Railcars are similar to conveyors in that they can handle high volumes well over long distances. They can also handle coarse, blocky materials. Railcars, however, have a high initial capital cost and are limited to $\sim 3 \%$ grade. The literature and interviews indicated that railcars were a declining technology in surface mining, being replaced by trucks or conveyors where new equipment purchase is economically feasible. The losses in railcars therefore were discounted.

\subsubsection{Shaft Mining}

Shaft mining differs from surface mining in that there is very little of the exposing (removal of overburden) or loading that has been previously described. In shaft mining, the deposit of coal, ore, or mineral is typically removed by a continuous mining system. The continuous miner has many variations, and we will broaden the usual definition to include borers and long wall planers because they all involve some rotating auger or drum studded with teeth, which we will call the cutter drum assembly. This assembly rotates against the mine surface, removing chunks of material with its rows of teeth. The material is then simultaneously gathered, partially crushed, and fed onto an attached conveyor. This conveyor then carries the material to either a dumping station or to the surface. An example of one type of continuous mining machine is shown Figure 2.4. The components that compose the main tribological losses for continuous mining systems are given in Table 2.17 and discussed below. Table 2.18 summarizes the annual U.S. production of underground minerals. 


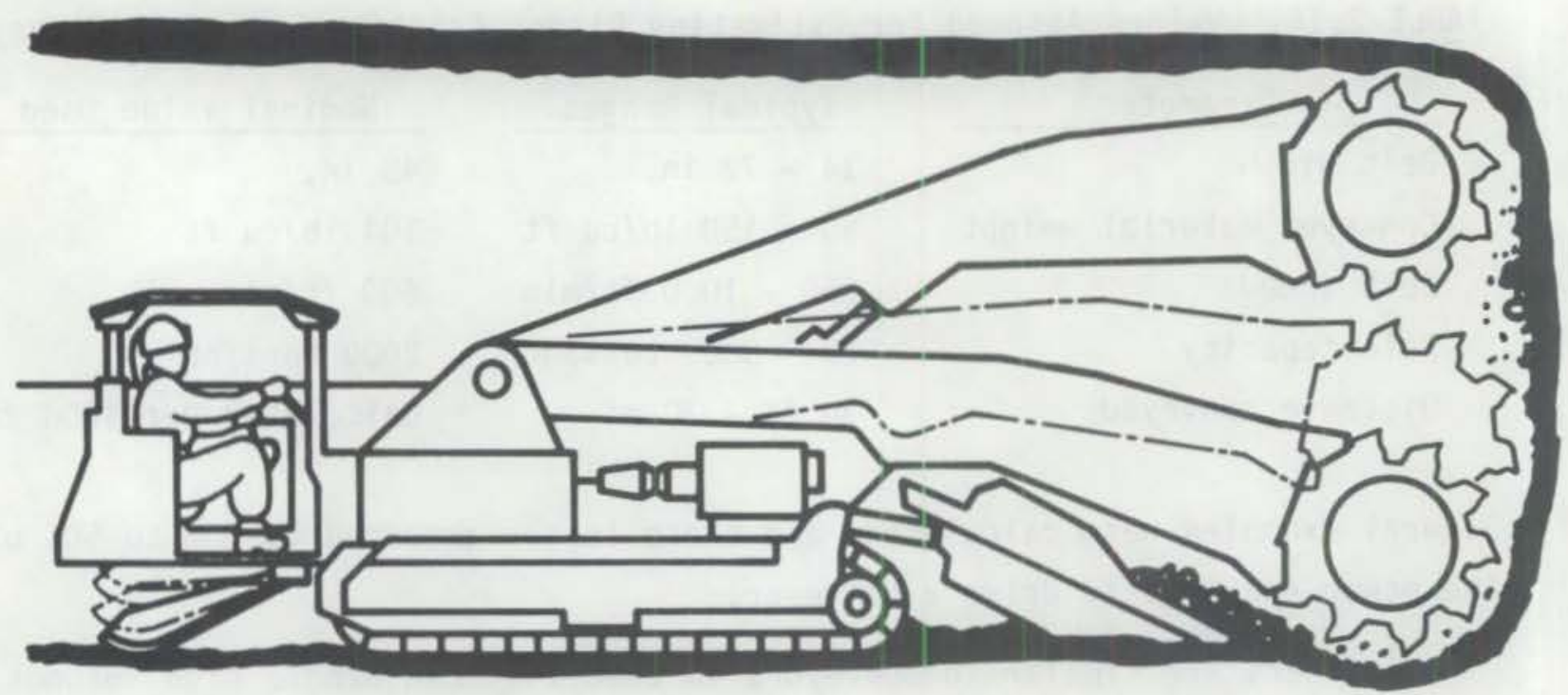

FIGURE 2.4. One Type of Continuous Mining Machine

TABLE 2.17. Shaft Mining

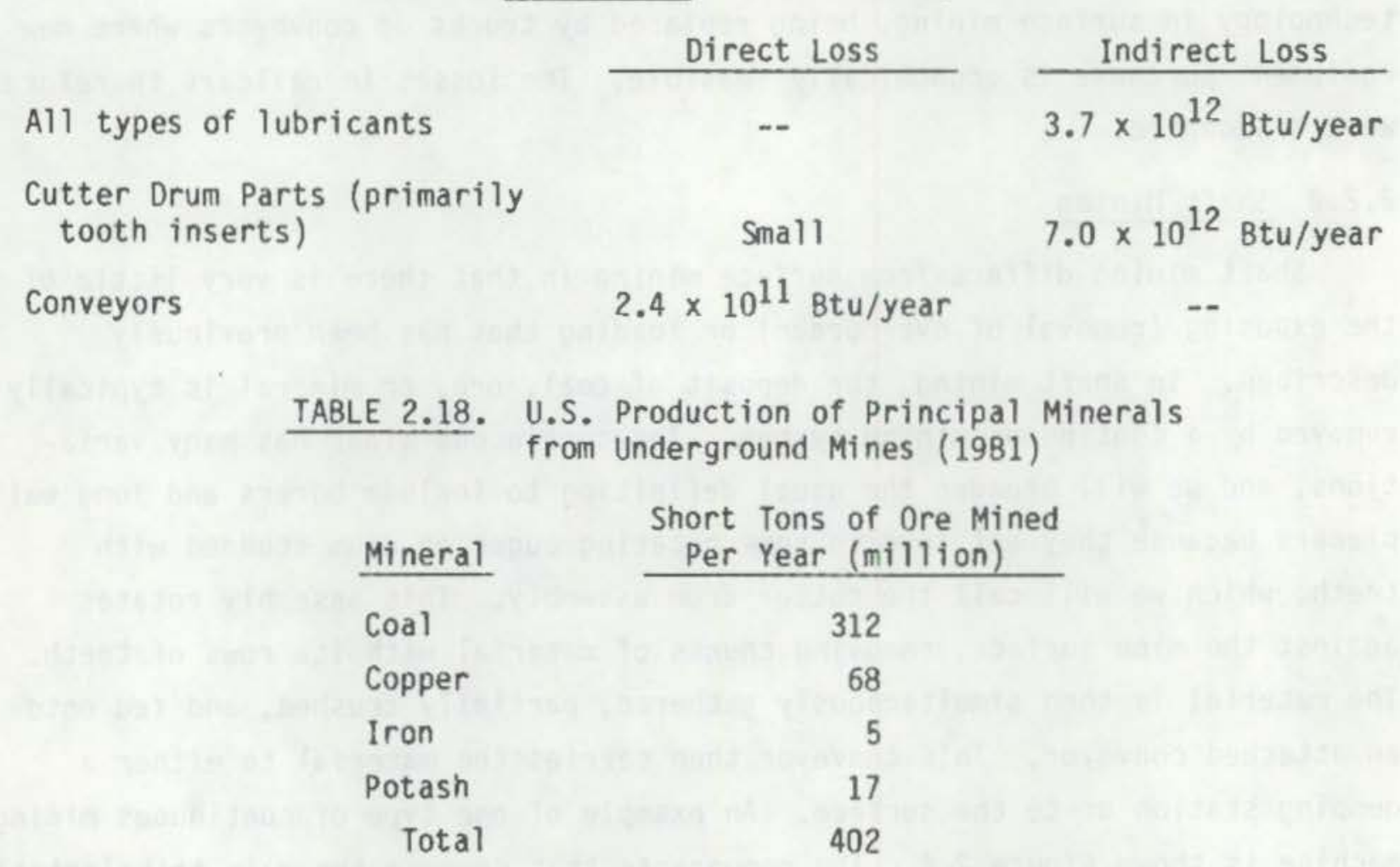




\section{Lubricants}

Many types of hydraulic equipment are used in shaft mining. Roof bolters, roof support jacks, drills, loaders, and the continuous miners all use hydraulics. Much of the lubricant loss can be attributed to improper selection and maintenance of lubricants. Lubricant contamination by dust, air or water is a major cause of wear in hydraulic machinery, bearings, and gearing in the mining industry because a contaminated fluid carries particles that accelerate the tribological processes that the lubricant was intended to combat. In some shaft mining applications, the lubricant must be deliberately diluted with water to reduce fire hazards. This lubricant compromise causes increased wear rates in hydraulic systems.

Seal leakage can account for up to 5000 gallons per day of lubricant loss in long-wall cutter operation. This loss is mainly observed on the 100 to 150 hydraulically actuated roof supports. The fluid lost is typically $5 \%$ oil in a water emulsion. Therefore, up to about 250 gallons of oil per day may be lost.

\section{Cutter Drum Parts}

Interviews with researchers from several manufacturers of continuous mining systems revealed that the mining action of the teeth is more of a fracture mechanism than a cutting action. A cutting action would involve significant friction losses, whereas fracture of the material involves less friction losses.

Other friction interfaces consistently indicated by the manufacturers and one mine operator were the chassis bottom, propulsion treads, and conveyors. Tribological losses in the first two wear areas were indicated as being negligible. The conveyor losses, however, will be discussed in the following section.

The replacement rate of the continuous miner teeth was estimated both by a mine manager and manufacturers of the equipment.(a) On the average, where some

(a) Personal communication with Frank Kendric, Product Manager for Continuous Miners, Joy Manufacturing Company, Pennsylvania, February 14, 1984. 
rocks are encountered in the cutting, 1 cutter bit will need to be replaced per 5 tons of ore. Cutting pure coal, potash, soda ash, or salt will require 1 bit per 20 tons.

\section{Conveyors}

The same assumptions used for conveyors in surface mining apply here. The principal materials conveyed, taken from Table 2.18, are coal, iron ore, copper ore, and potash. The average distance conveyed in shaft mining is $\sim 12,000$ feet.

\subsection{ORE PROCESSING}

Grinding (e.g., milling, pulverizing) materials that have been mined results in a significant amount of both direct and indirect tribological energy losses. Although "ore processing" is used in processing a large range of materials, most of the discussion in this section will focus on metals because of the large tonnages involved and the highly abrasive behavior of metal ores.

Processing components that experience tribological energy losses include the following:

- crushers

- grinding mills

- slurry pumps

- cyclone separators.

As discussed in the following paragraphs, while the other components should not be ignored, grinding mills account for the largest tribological energy losses.

\subsubsection{Direct Energy Losses in Ore Processing}

In the copper industry, $\sim 30 \%$ of the total energy expended is used to concentrate the ores from typical values of $0.5 \%$ copper ores (as mined) (Chang, Danver and Cigan 1975). Concentration is accomplished by crushing and grinding ores into powder ( $85 \%$ minus 100 mesh) from which gangue (rock and useless minerals) and metal are separated. This process requires about $24 \times 10^{6}$ Btu per ton of copper produced. Of this energy consumption, about $0.25 \%$ is lost in the mill support bearings; $1.5 \%$ is lost in the main gears; and up to $0.75 \%$ is 1 ost 
in additional reducer gears when they are required. The bearing friction loss in milling various metals was computed by assuming a conservative total tribological loss of $(.25+1.5)=1.75 \%$ (ignoring reducer gear losses). Table 2.19 summarizes direct tribological energy losses from bearings in selected milling operations in the U.S.

\subsubsection{Indirect Energy Losses}

The wear rates for key steps in ore processing are listed in Table 2.20. As the table indicates, wear of ore grinding equipment represents the largest indirect tribological loss in ore processing. This loss comprises an average of about 1.5 pounds of iron alloy (balls, rods and liners) per ton of ore or minerals ground. Alternatively, in milling coal for power plants, only 0.004 pound of steel is worn per ton of coal processed. This difference

TABLE 2.19. Direct Tribological Energy Losses in Grinding

\begin{tabular}{|c|c|c|c|}
\hline Industry & Year & $\begin{array}{c}\text { Grinding } \\
\text { Energy } \\
\left(10^{12} \text { Btu }\right)\end{array}$ & $\begin{array}{c}\text { Direct Tribological } \\
\text { Portion of Grinding } \\
\text { Energy (Bearing } \\
\text { Losses) }\left(10^{12} \text { Btu) (a) }\right.\end{array}$ \\
\hline Copper & 1973 & 39.5 & 0.69 \\
\hline Alumi num & 1973 & 3.5 & 0.03 \\
\hline Iron & 1973 & 40.9 & 0.72 \\
\hline
\end{tabular}

(a) Bearing losses in grinding $=0.75 \% \times$ grinding energy.

TABLE 2.20. Wear Rates in Key Ore Processing Steps (Tefler 1980)

\begin{tabular}{l}
\multicolumn{1}{c}{ Process Step } \\
\hline Crushing \\
Screening \\
Grinding \\
Pumping \\
Classifying \\
Mineral separation
\end{tabular}

\begin{tabular}{r}
$\begin{array}{c}\text { Wear R } \\
\text { (grams metal }\end{array}$ \\
\hline 50 \\
2 \\
700 \\
5 \\
3 \\
2
\end{tabular}


reflects the observed variations in abrasion between coal and other materials. Because this wear represents an embodied energy of $\sim 35 \times 10^{6}$ Btu per ton, the indirect tribological energy loss for ore grinding is estimated to be $\sim 26.25 \times 10^{3}$ Btu per ton of ore or minerals ground per year. Based on the production figures presented in Tables 2.11 and 2.18 for materials that are typically ground (iron ore, copper ore, clay, phosphate, and potash), the total tribological loss associated with wear from grinding is $\sim 1.85 \times 10^{13} \mathrm{Btu} /$ year.

Crushing constitutes the second greatest source of indirect energy loss. The magnitude of loss in ore crushing is only about $7 \%$ as large as that for ore grinding per ton; however, more minerals are subject to crushing. The total tribological loss associated with crushing is estimated to be $4.3 \mathrm{x}$ $10^{12} \mathrm{Btu} /$ year.

\subsubsection{Other Ore Processing Activities}

The remaining areas where tribology influences ore processing include slurry pumps and cyclone separators. Slurry pump impellers and cases are subject to erosion and low stress abrasion, and they require fairly frequent replacement. Generally, back-up pumps are included to allow the system to continue operating during pump maintenance. Although wear of slurry pump components is significant to plant operations, it does not constitute nearly as much embodied energy as does wear of grinding mill media.

Cyclone separators are used to separate fine ore particles from larger particles that must return to the mill. Although they do experience wear, the resultant material loss is not a major concern. Of minor importance is that orifice wear can affect classifier efficiency. Consequently, frequent maintenance checks are needed.

\subsection{DRILLING}

A rotary drilling rig, shown in Figure 2.5, is used primarily for oil and gas extraction, and to a lesser extent for water, sulfur, carbon dioxide, and geothermal wells. The three rig components with significant tribological losses are shown in Figure 2.5: the mud pump, drill string, and bit. 


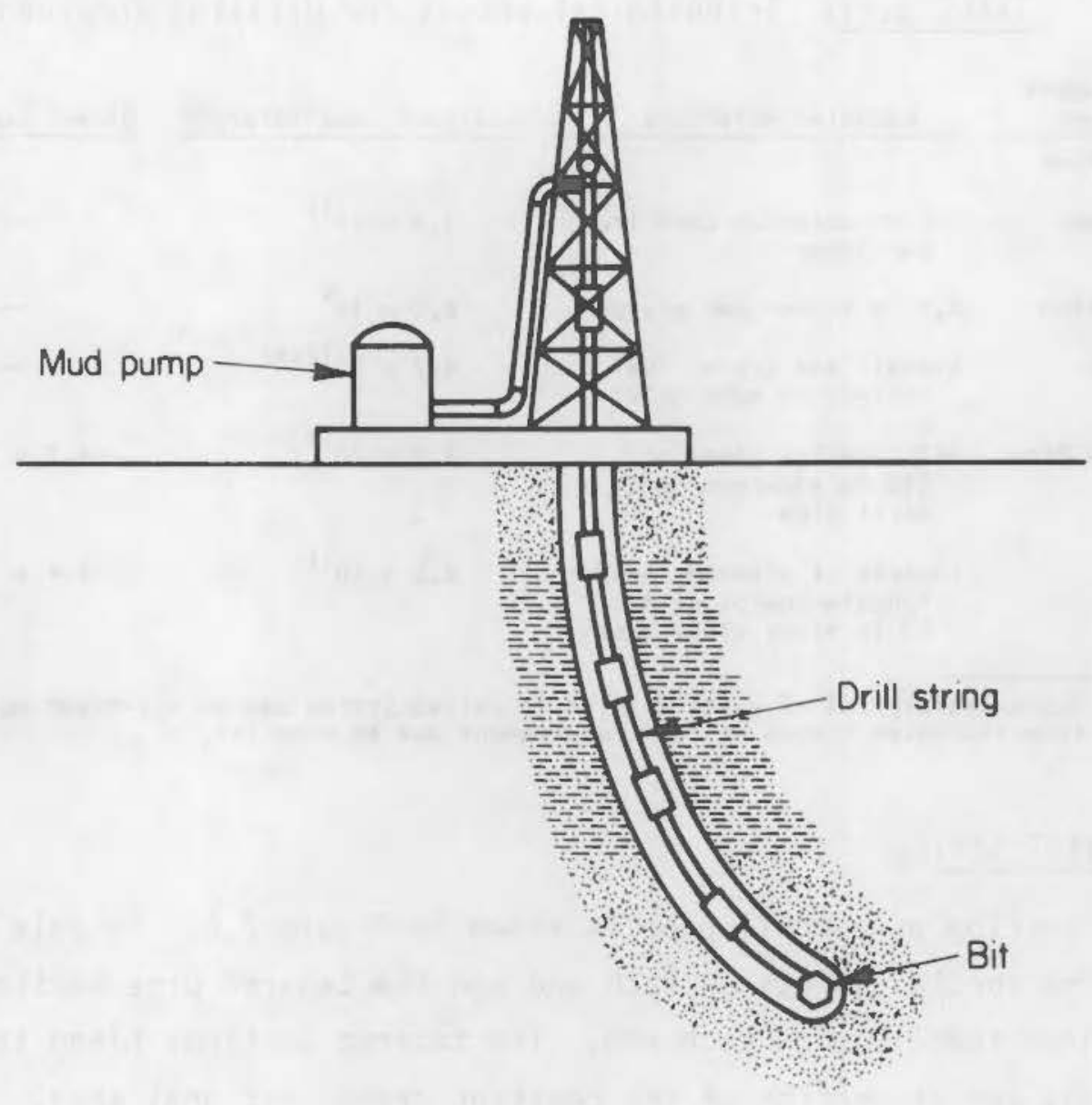

FIGURE 2.5. Rotary Drilling Rig--Tribological Components Having Significant Tribological Losses

The bit, which cuts or breaks the rock, screws on to the drill string, which is several pipe sections fastened together with special joints. The drill string is driven from above ground, generally by a diesel engine, and subsequently turns the bit. The mud pump is used to pump a lubricant/coolant down the drill string, through the bit, and back up the hole, carrying away chips cut by the bit. Table 2.21 summarizes the significant tribological losses for drilling components. The following sections contain more detailed descriptions of the components listed in Table 2.21, including their geometry, function, and failure mechanisms. 


\section{TABLE 2.21. Tribological Losses for Drilling Components}

\begin{tabular}{|c|c|c|c|c|}
\hline $\begin{array}{c}\text { Component } \\
\text { Name }\end{array}$ & Embodled Materlals & Indirect Loss $(B+u / y r)$ & DIrect & Loss $(B+u / y r)$ \\
\hline \multicolumn{5}{|l|}{ Mud Pump } \\
\hline Liner & $\begin{array}{l}150 \text { lb chromlum cast Iron } \\
\text { per IIner }\end{array}$ & $1.9 \times 10^{10}$ & & - \\
\hline Plston & 2.5 ib rubber per plston & $6.0 \times 10^{9}$ & & - \\
\hline Mud & $\begin{array}{l}\text { Asphalt and diesel fuel } \\
\text { (oll-based muds on }(y)\end{array}$ & $4.7 \times 10^{12(a)}$ & & -- \\
\hline Drill Plpe & $\begin{array}{l}540 \text { ib alloy steel or } \\
320 \text { ib aluminum per } \\
\text { drili plpe }\end{array}$ & $2.6 \times 10^{11}$ & 4.3 & $\times 10^{11}$ \\
\hline Bits & $\begin{array}{l}\text { Inserts of dlamond, and/or } \\
\text { tungsten carblde in } \\
40 \text { ib alloy steel base }\end{array}$ & $6.2 \times 10^{11}$ & 1.4 & $\times 10^{11(b)}$ \\
\hline
\end{tabular}

(a) Approximately 20 of wells arilled in United States use an oll-based mud.

(b) From Increased torque or time requilrement due to worn bit.

\subsubsection{Drill String}

One section of a drill pipe is shown in Figure 2.6. Notable features include the special joints on each end and the tapered pipe sections approximately three feet long on each end. The tapered sections blend the pipe ends to the long center section of the constant cross-sectional area.

The drill string is smaller in diameter than the drill bit and consequently smaller than the hole drilled. A direct tribological loss results because of friction at the interface of the drill string and drill bit. The bit tends to deviate from drilling a straight hole because of several factors, including the high load on the bit, the hardness of the rock formations being drilled, and inclinations of the earth's formations. The resultant curvature in the hole causes the drill string to rub at the tool joints as it bends around these curves. Table 2.21 shows the resulting energy loss.

The loss was calculated using the assumptions of Table 2.22, which were found in the literature (Dunnett 1974; Lubinski 1961) and obtained through conversations with drilling contractors and drilling component manufacturers. The force generated at the pipe-to-hole wall by the bending and tension of the pipe was arrived at by $A$. Lubinski as "A tentative but rather conservative 


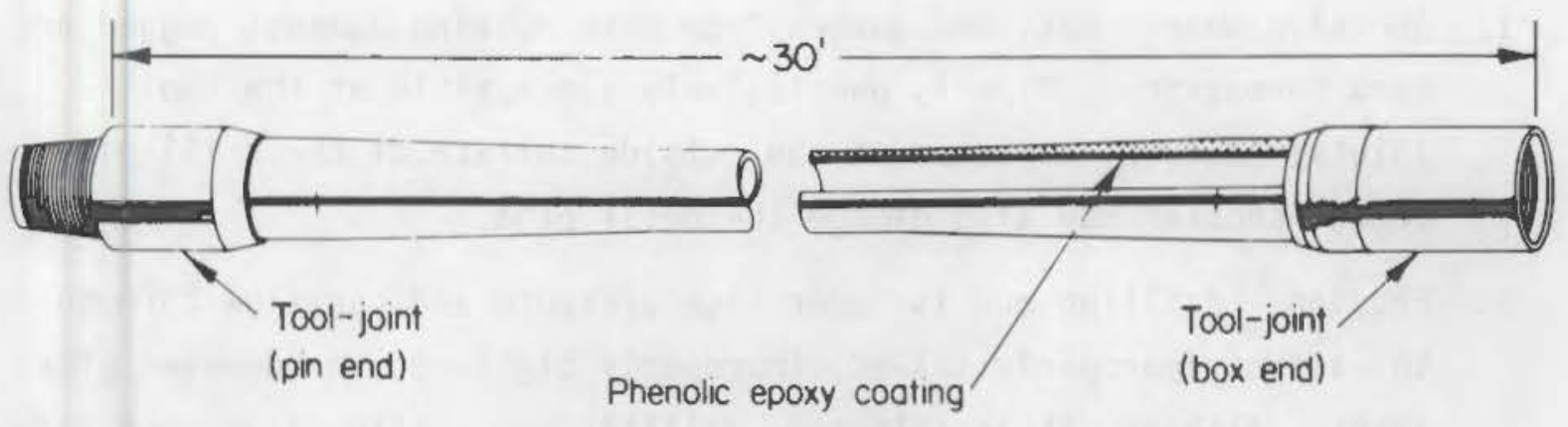

Note Hardened steel or weld deposit

on both drill collars

\section{FIGURE 2.6. Anatomy of a Drill Pipe}

TABLE 2.22. Operating Conditions of a Rotary Drilling Rig

\begin{tabular}{|c|c|c|}
\hline Value & Range & Nominal Value \\
\hline Drilling Speed & 0 to $200 \mathrm{rpm}$ & $100 \mathrm{rpm}$ \\
\hline Pipe Outside Diameter & 2.4 to $6.6 \mathrm{in}$. & $4.5 \mathrm{in}$. \\
\hline Pipe-to-Wall Friction in Drilling Mud & 0.05 to 0.25 & 0.10 \\
\hline Pipe Length Between Tool Joints & 18 to $45 \mathrm{ft}$ & $30 \mathrm{ft}$ \\
\hline Hole Curvature & 0 to $10^{\circ} / 100 \mathrm{ft}$ & $1.5 \% 100 \mathrm{ft}$ \\
\hline Force at Pipe-Wall Interface & 0 to $>6000 \mathrm{lb}$ & $2000 \mathrm{lb}$ \\
\hline Drilling Penetration Rate & 5 to $50 \mathrm{ft} / \mathrm{hr}$ & $50 \mathrm{ft} / \mathrm{hr}$ \\
\hline
\end{tabular}

value of the maximum tolerable value of the tool joint-to-wall force ..." (1961). The conservative estimate of this force will lead to a conservative estimate of the direct loss. The faster end of the typical drilling penetration range was also used to yield the most conservative estimate of the direct energy loss.

The drill pipes that make up the drill string are attacked by various mechanisms, both tribological and otherwise, which result in indirect loss of drill pipe components and eventually the entire drill pipe. The causes and sites of tribological attack on the pipe are as follows: 
1. Abrasive Wear - cuts and gouges from pipe rubbing against ragged and hard formations. Pipe is particularly susceptible at the tool joints; however, abrasion of the outside surface of the drill pipe center section may also damage the drill pipe.

2. Erosion - drilling mud is under high pressure and can flow through threads of improperly sealed, improperly tightened, or damaged pipe joint. Although it is filtered, drilling mud retains fine rock particles and is extremely abrasive. Even if severe erosion is not caused by a leak, uniform wear from this mechanism will eventually reduce the pipe cross-sectional area, thereby reducing the pipe's load-carrying capability.

The causes and sites of attack of nontribological mechanisms are listed below because they interact with and are compounded by the tribological mechanisms.

1. Corrosion - occurs particularly in dents and scratches in tool joints caused by tongs and chains used to tighten pipe sections together or slips used to suspend pipe. Drilling lubricant (mud) often contains corrosion inhibitors, but pipe can rust away while standing idle in racks exposed to air. Insides of pipes are protected from corrosion (and wear to some extent) by a coating of phenolic epoxy.

2. Fatigue - the drill string must endure cyclic stresses when rotated in a crooked hole. The failure often occurs at a stress riser caused by any of the above mechanisms (such as an abrasive-wear scratch).

Drill pipe is reconditioned several times before being retired as an indirect loss. A drill pipe's life cycle is as follows. It starts out as Class 1 , new pipe, in accordance with the American Petroleum Institute's Inspection and Classification system. As it is used, it is inspected at various times for wall wear, dents, crushing, stretching, cuts, gouges, corrosion, cracks, and erosion. In some cases, a complete tool-joint replacement is welded on to save a drill pipe. As a pipe degrades from the above mechanisms, it is moved to Class 2 and Class 3 for weakened pipe. These classes of pipe will not be used in critical applications such as very deep holes where a pipe failure is very 
costly. The extent of the repair performed on drill pipe is evidenced by the existence of companies whose sole purpose is to repair pipe defects. The life predictions for the drill string were taken from conversations with one of the companies that repair drill pipe.

\subsubsection{Mud Pumps}

As previously described, a mud pump delivers cutting fluid (called drilling mud) down the drill string to flush drilled chips to the surface. The entire mud pumping system is shown in Figure 2.7. The mud flows from the supply tank, down the drill string, and back up the hole to return to the mud tank. During this trip, the mud performs several functions, including removing the cuttings from the hole, cooling and lubricating both the bit and drill string, and exerting hydrostatic pressure to support the hole wall.

\section{Drilling Mud}

The term "drilling mud" indicates a liquid (water or oil) with solid in suspension. The water-based fluids are used more often than the oil-based fluids because water is less expensive than oil, and a typical hole will require thousands of gallons. The properties of the mud are adjusted by additives. Hundreds of additives are produced under various trade names; however, their intended function may be broken down into just a few categories. Some additives adjust the viscosity and flow properties; some adjust the density of the mud, and others plug leaks in the hole wall by a process called filtration.

Although the mud passes through mechanical desanders and desilters, a large fraction of the drilled solids remain in suspension (Goldsmith and Hare 1982). The mud is then a fine slurry of rock and minerals that is highly abrasive. The effects of the abrasive wear of the mud on the drill string have already been discussed. The following discussion focuses on abrasive wear in the mud pump itself.

\section{Mud Pump Cylinder Liners}

The pumping of the highly abrasive mud, as described above, has long been recognized as a significant wear problem. For this reason, the mud pump has 


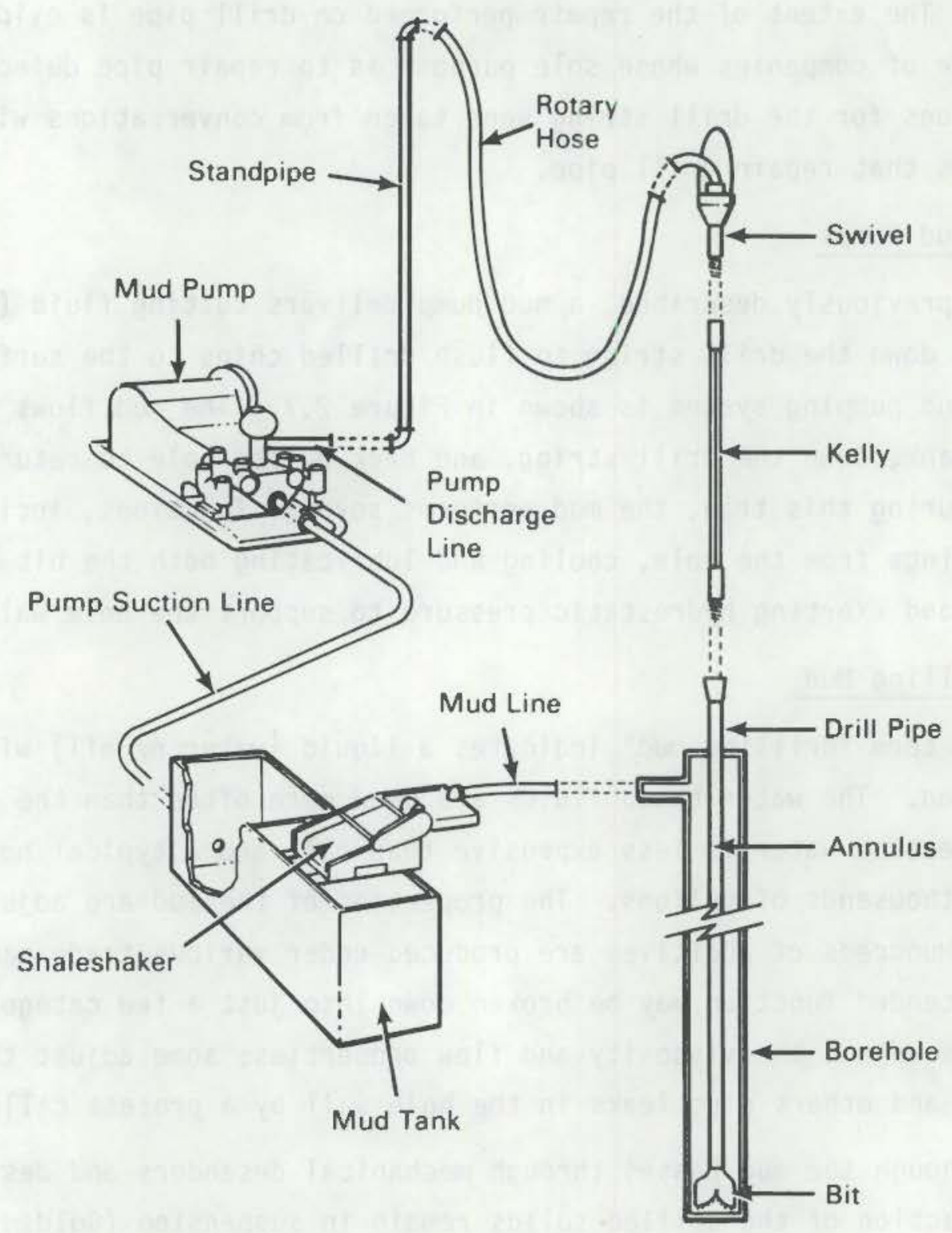

FIGURE 2.7. Drilling Mud Pumping System

been designed with expendable internal parts. The core of the pump is shown in Figure 2.8. In that figure, the cylinder liner (shown in cross section) is a replaceable insert in which the rubber piston reciprocates. The chamber typically operates under very high pressures of 2000 psi. Fine particles of mud are trapped at the piston-cylinder interface and cause three-body abrasive wear and erosion as the mud leaks past the piston (Lewis 1981). 


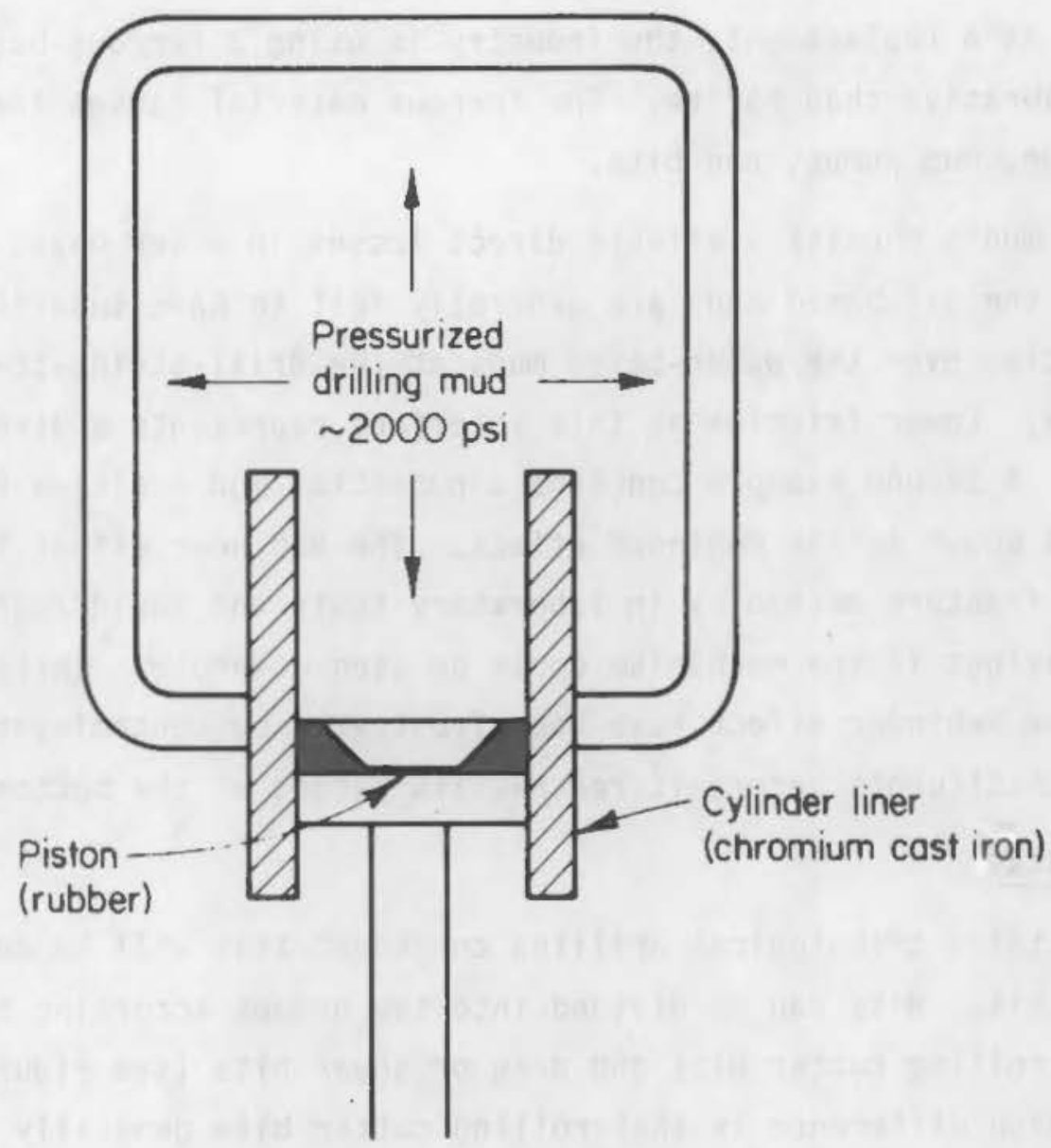

FIGURE 2.8. Schematic Drawing of Mud Pump Compression Chamber

\section{Mud Pump Pistons}

A mud pump piston, shown in Figure 2.8 , is typically a 6 - to 7 -inchdiameter rubber disk bolted to a steel piston rod. The pistons are also destroyed by the wear at the piston-wall interface. They typically must be replaced 10 times as often as the cylinder wall. This replacement frequency requires breaking down the pump as often as every 5 to 10 days.

\section{A Tribological Perspective on Drilling Mud}

The chemistry and functions of the drilling mud are very complex. The mud is very important tribologically because it affects both the direct and indirect losses of many of the other components in the drilling rig. For example, barite is a mineral product commonly used to vary the mud density. Drilling contractors and product manufacturers indicated that a barite shortage 
exists. As a replacement, the industry is using a ferrous-based compound that is more abrasive than barite. The ferrous material causes increased wear on drill pipe, mud pumps, and bits.

The mud's chemistry affects direct losses in other ways, also. For example, the oil-based muds are generally felt to have superior lubricating capabilities over the water-based muds at the drill-string-to-hole-wall interface. Lower friction at this interface represents a direct energy savings. A second example concerns a potential mud additive to enhance a phenomena known as the Rebinder effect. The Rebinder effect has been shown to aid rock fracture mechanics in laboratory tests and could represent a direct energy savings if the mechanism could be used downhole. Initial attempts to induce the Rebinder effect have been frustrated by contaminants that dilute the active constituents before it reaches its target at the bottom of the hole.

\subsubsection{Bits}

The third tribological drilling component that will be considered is the drilling bit. Bits can be divided into two groups according to their basic design: rolling cutter bits and drag or shear bits (see Figure 2.9). The basic design difference is that rolling cutter bits generally have three cones

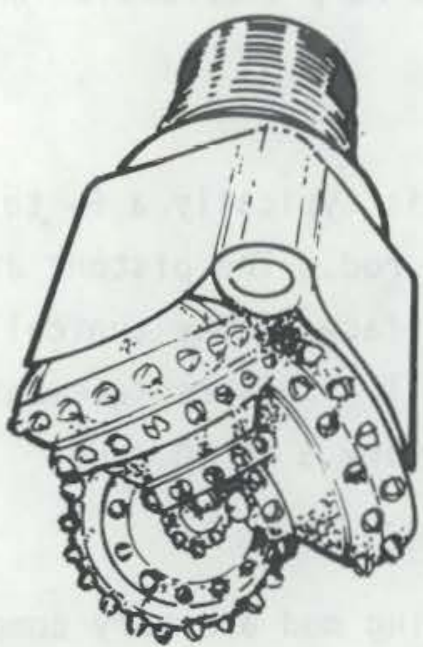

Rolling Cutter Bit

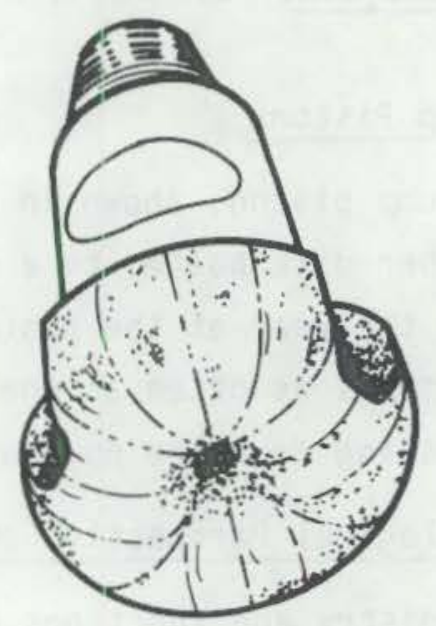

Shear or Drag Bit

FIGURE 2.9. Two Basic Drilling Bit Designs 
supported by bearings, whereas the shear bits are rigidly fixed to the drill string. The tribological attacks and defenses of each type of bit are described below. More emphasis will be given to the rolling cutter bits because they represent $\sim 90 \%$ of the current bit market.

\section{Shear Bits}

Most shear bits currently in use are polycrystalline (man-made) diamonds mounted on tungsten carbide--extremely wear-resistant materials. The main cause of failure for these bits was reported to be three-body abrasive wear. The wear sometimes degrades the surrounding alloy, allowing the inserts to be lost. Under extreme mud pressure and velocities, the surrounding metal will also erode. As stated above, however, the general cause of failure is abrasive wear in the extremely aggressive environment at the bottom of the hole.

\section{Rolling Cutter Bits}

This type of bit consists of three alloy steel cones each having rows of teeth. The teeth can be composed of a solid hard material or a diamond or carbide insert, or can be studded with wear-resistant inserts. The rollers are supported by both radial and thrust bearings. Rolling cutter bits fail because of seal failures, which lead to bearing failures, wear of the inserts and supporting material and, occasionally, fracture of a cone or erosion of the steel that supports the inserts. Conversations with two major bit manufacturers indicated that $75 \%$ to $80 \%$ of the bits fail in the bearing seals, and this failure allows drilling mud to abrasively destroy the bearing. The bearing seals are weakened by extreme pressures, high temperatures from geothermal and frictional heating, chemical attacks from corrosive deposits drilled, or simply abrasive attack of the drilling mud. The remaining $20 \%$ to $25 \%$ of the bits were indicated to simply having been worn out in three-body abrasive wear.

\section{A Tribological Perspective on Bits}

The bit condition directly affects the direct energy losses in the drill string. If a bit is worn, the drilling rig operator can either allow reduced penetration rates or raise the drill string load and resulting torque to maintain a given drilling rate. If the bit penetration rate is reduced $50 \%$, the drill string will have to turn twice as long, and all of the energy consumed 
during the longer drilling time is the result of reduced bit performance. If the drilling load and torque are raised, the additional torque requirement represents a direct energy loss. The indirect and direct losses have been estimated and are included in Table 2.21.

These two parameters, the rate of penetration and drilling torque, are therefore two of the drilling parameters that are monitored and used to determine when the drill string should be pulled to change bits. The process of pulling up a drill string, called "tripping out" by the industry, is costly hoth in terms of time and energy. For this reason, there is continuing research on bit life.

One technology that is being used more frequently partly because of tribological advancements is the downhole drilling motor. There are two designs of bit drives that do not rely upon the drill string to rotate the bit but rather generate the torque at the bottom of the hole. These are called downhole bit motors. Both of the designs convert the hydraulic energy of the drilling mud to mechanical power. Because the drill string is not required to turn, frictional energy losses are reduced and indirect loss savings result from reduced damage to the drill pipe.

\subsection{SUMMARY OF TRIBOLOGICAL ENERGY LOSSES IN MINING}

Tables 2.23, 2.24, and 2.25 summarize the tribological energy losses associated with the principal mining operation activities. The generic tribological mechanisms contributing to energy losses for each operational activity are identified in Table 2.23. Direct and indirect energy losses are given in Tables 2.24 and 2.25, respectively. Additional information on the principal energy form consumed by an operation, the energy loss rate, material type worn, and material wear rate is also provided in Tables 2.24 and 2.25 .

Three-body abrasion was identified most often as contributing to tribological losses in mining activities. The next two most common sources were impact wear and high friction. Of course, the nost commonly occurring loss mechanisms are not necessarily the cause of the largest energy losses. While it is important to recognize where and how tribological losses are occurring, the information provided in Table 2.23 is more qualitative than quantitative. 
TABLE 2.23. Generic Tribological Loss Mechanisms in Mining

Operational

Activity

Generic Tribological Mechanism(a)
(1) (2) $\quad$ (3) $\quad$ (4) $\quad$ (5)

Surface Mining

Exposing and Digging

Loading

Transporting

$x$

$x$

$x$

$x$

Shaft Mining

Digging

Transporting

Ore Processing

Drilling

Mud Pumps

Drill Pipe

Bits

(a) (1) Three-Body Abrasion.

(2) High-Stress Gouging.

(3) Impact Wear.

(4) High Friction.

(5) Erosion.

(6) Lubricated Wear.

Indirect tribological losses are almost five times greater than direct losses in mining. Indirect tribological losses are associated with the wearing out of equipment and also include lubricant losses and drilling mud consumption. The principal indirect loss items are crushers, grinders, truck tires, digging equipment teeth, and drilling mud. Carbon or low-alloy steel is the most common material subject to wear and also contributes the most to the indirect energy total.

Direct tribological losses are associated with the energy to overcome friction between two surfaces. The most important direct loss items are power 
TABLE 2.24. Annual Direct Tribological Energy Losses in Mining

\begin{tabular}{|c|c|c|c|}
\hline Operational Activity & $\begin{array}{l}\text { Princlpal Energy } \\
\text { Form Consumed }\end{array}$ & Energy Loss Rate & $\begin{array}{l}\text { Total Energy } \\
\text { Loss }\left(10^{12} \text { Btu }\right) \\
\end{array}$ \\
\hline \multicolumn{4}{|l|}{ Surface Mining } \\
\hline Exposing and Digging & Electricity & $625 \mathrm{\theta tu} / \mathrm{yd}^{3}$ & 5.0 \\
\hline Looding & Dlesel & $9 \mathrm{~B}+u / y d^{3}$ & 0.07 \\
\hline Transporting & Electrlalty & $528 \mathrm{Btu} / \operatorname{ton}-\mathrm{ml}$ le & 3.8 \\
\hline \multicolumn{4}{|l|}{ Shaft MInIng } \\
\hline Digging & - & $\cdots$ & - \\
\hline Transporting & Electricity & $528 \mathrm{Btu} / \mathrm{ton}-\mathrm{mlle}$ & 0.24 \\
\hline Ore Processing & Electriclty & 1.758 of grinding energy & 1.44 \\
\hline \multicolumn{4}{|l|}{ Drilling } \\
\hline Mud Pumps & - & - & - \\
\hline Drill PIpe & Dlesel & $1200 \mathrm{Btu} / \mathrm{ft}$ drllled & 0.43 \\
\hline \multirow[t]{2}{*}{ Bits } & Dlesel & $400 \mathrm{Btu} / \mathrm{ft}$ drilled & 0.14 \\
\hline & & & 11.12 \\
\hline
\end{tabular}

TABLE 2.25. Annual Indirect Tribological Energy Losses in Mining

\begin{tabular}{|c|c|c|c|}
\hline Operational Activity & Materlal Type Worn & Materlal Mear Rate & $\begin{array}{l}\text { Total Energy } \\
\text { Loss }\left(10^{12} \text { Btu }\right) \\
\end{array}$ \\
\hline \multicolumn{4}{|l|}{ Surface Mining } \\
\hline Exposing and Digging & Steel & 27,250 ton $/ y r$ & $1.2^{(0)}$ \\
\hline Loading & Steol & $1,750+o n / y r$ & 0.06 \\
\hline Transporting & "Rubber" & $0.03 \mathrm{Ib} / \mathrm{yd} \mathrm{d}^{3}$ & 12.0 \\
\hline \multicolumn{4}{|l|}{ Shaft MIning } \\
\hline Digging & Steol & $1 \mathrm{lb} /$ ton & $10.7^{(a)}$ \\
\hline TransportIng & - & - & - \\
\hline Ore Processing & Steol & $1.5 \mathrm{lb} /$ ton & 22.8 \\
\hline \multicolumn{4}{|l|}{ Drlliling } \\
\hline Mud Pumps & Cast Iron, "rubber" & $\begin{array}{l}2 \text { ib Iron } / 1,000 \mathrm{ft} \\
2.5 \text { ib rubber } / 10,000 \mathrm{ft}\end{array}$ & $4.7^{(b)}$ \\
\hline Drill PIDe & Alloy steel, aluminum & $\begin{array}{l}7.3 \text { ib steel } / 1,000 \mathrm{ft} \\
4.3 \text { ib alum, } / 1,000 \mathrm{ft}\end{array}$ & 0.26 \\
\hline Bits & Alloy steel & $69 \mathrm{lb} / \mathrm{t}, 000 \mathrm{ft}$ & 0.62 \\
\hline & & & 52.34 \\
\hline
\end{tabular}

(a) Total energy loss Includes lubrlcant loss.

(b) Total energy loss includes drliling mud consumption.

shovels, draglines, and conveyors. Direct energy loss activities in mining were found to be consumers of electricity and/or diesel fuel. The largest direct loss items (noted above) principally consumed electricity. 


\section{R REFERENES}

Beeman, H. G. 1978. Factors Affecting the Serwice Life of Large Dianeter Wire Rope. Pacific Northwest Laboratory, Richland, Washington.

Chang, Y. A., W. M. Danver and J. M. Cigan, eds. 1975. Energy Use and Consumption in the Metals industry. The Metallurgical Society of the American Institute of Mining Engineers, New York, New York.

Coal Age. July 1982. "Grace Hanna Bolsters Its Top Spot." pp. 114-111.

Conzeyor Equipment Manufacturers Association ICEMA). 1979. Belt Conveyors for Bulk Materials. C81 Publishing Company, Inc., Boston, Massachusets.

Cummins, A. and I. Given. 1973. S.M.E. Mining Engineering Handbook. American Institute of Mining, Metallurgical and Petroleum Engineers, Inc., New York.

Dunnett, E. G., ed. 1974. "Internationa1 Assoclation of Drilling Contractors Drilling Manual. "Ninth Edition. International Association of brilling contractors, Washington, D.c.

ESco Corporation. Undated. stories of the Year. Volume 3, No. 1-28, ESCO Corporation, Danville, Illingls.

Goldsmith, R. and M. Hare. June 1982. "Solfd Analysis Improves Mud Cost Control." World Dil. Pp. 167-170.

Lewis, E. C., II. July 1981. "Mud Pump Failure Analysis." Petroleum Engineer International. pp. 162-178.

Lubinsk:, February 196:. "Maximum Permissible Dog-Legs in Rotary Boreholes. " Journal of Petroleun Technology. pp. 175-194.

Harbut, C. F. 1935. Soils of the U.S. At as of Anerican Agricalture, Part II:, U.S. Government Printint office, Washington, D.C.

Pfleider, E. P., ed. 1968. Surface Mining. Seeley H. Mudd Series, American Institute of Mining and Metallurgical and Petroleum Engineers, New York.

Tefler, N. 1980. "Wear in Ore Processing lachinery." In Wear Control landbook. Peterson and Winer, eds. Anerican Society of Mechanical Engineers, New York, New York.

U.s. Census Bureau. 1981. 1977 Census of Mineral Industries. U.S. Census Bureau, Washington, D.C.

U.S. Department of Interior. 1970. The National Atlas of the united States of Ameri.a. U.5. Department of Interior, Geological Survey, Washington, D, C.

Watwod, ${ }$, ed. 1983. Somon Surface Mining Equipment Troubleshooting-large Uining Machinery Directory. Mchigan tech. Untversity, Michigan. 



\subsection{AGRICULTURE}

Agriculture is the work of cultivating the soil, producing crops, and raising livestock. Mechanization has replaced most human and animal labor in agriculture over the last several decades, and this machinery and other faming materials require enormous amounts of energy. An important element of this agricultural energy consumption can be attributed to tribology. The purpose of this chapter is to identify where significant tribology sinks exists in agriculture and to estimate the energy consumption in these sinks.

\subsection{INTRODUCTION}

The agricultural industry includes several major groups of the Standard Industrial Classification (SIC) (Table 3.1). Some of these groups overlap with other main industry groups, such as chemicals and mining. This chapter focuses on crop production because it accounts for $80 \%$ to $90 \%$ of the total agricultural energy tudget. A limited review of tribology sinks in livestock production is also included. The tribological sinks in agricultural chemical production and mining are covered in the mining and chemicals chapters (2.0 and 5.0 ) of this report, so are not included here. Agricultural services were excluded from the review because of the apparent lack of tribology sinks having significant energy use.

\subsubsection{Agriculture End-Use Energy Consumption}

The primary mechanized activities in crop production include 1) soil preparation, 2) planting, 3) cultivation, 4) harvesting, 5) processing, and

TABLE 3.1. Major Agricultural Groups of the Standard Industrial Classification

$\begin{array}{ll}\text { SIC Code } & \text { Crop Production } \\ 01 & \text { Livestock Production } \\ 02 & \text { Agricultural Services } \\ 07 & \text { Chemical (mainly } 287 \text {-agri chemicals) } \\ 28 & \text { Mining (mainly 147-chemical and fertilizer mining) }\end{array}$


6) transportation. For livestock production, the main nechanized activities include feed transport, husbandry, processing, and market transportation.

The total energy consumption in agriculture in 1978 was 2.037 quad and is shown in Tables 3.2 and 3.3 for each end use in crop and livestock production, respectively. For crop production, soil preparation before planting accounts for 0.173 quad per year, largely for powering agricultural machinery. Planting and cultivation consume less energy, 0.097 quad annually. Harvesting requires about 0.154 quad per year, while transportation requires 0.19 q qual per year.

TABLE 3.2. Energy Input by Farm Funct on and qegion for crop Production, 1978 U. 5 . Department of Agriculture 1980)

\begin{tabular}{|c|c|c|}
\hline Fartin Function & $\begin{array}{c}\text { Total } \\
\text { (billion btu) }\end{array}$ & Percent \\
\hline Preplanting & 173,388 & 9.5 \\
\hline Planting & 47,516 & 2.6 \\
\hline Cultivation & 49,997 & 2.8 \\
\hline Harvest & 154,125 & 8.5 \\
\hline Farm Pickup & 129,767 & 7.1 \\
\hline Fertilizer Applic. & 12,873 & 0.7 \\
\hline Pesticide Applic. & 16,897 & 0.9 \\
\hline Farn Trucking & 67,733 & 3.7 \\
\hline Farm Auto-Crops & 60,757 & 3.3 \\
\hline Grain Handling (vehs) & 1,903 & 0.1 \\
\hline Grain handling (Mach) & 116 & 0 \\
\hline Grop Drying (on-Fn) & 71,482 & 3.9 \\
\hline Irrigation & 252,147 & 13.9 \\
\hline Frost protectuon & 39,829 & 2.2 \\
\hline Fertillzer & 651,876 & 35.9 \\
\hline Pesticides & 68,202 & 3.8 \\
\hline Electricity & 5,802 & 0.3 \\
\hline Miscellaneous & 14,142 & 0.8 \\
\hline Total & $1,818,562$ & 100.00 \\
\hline
\end{tabular}


TABLE 3.3. Energy Input by Operation and Region for Livestock Production, 1978 (U.S. Department of Agriculture 1980)

\begin{tabular}{|c|c|c|}
\hline Operation & $\begin{array}{c}\text { Total } \\
\text { (billion Btu) } \\
\end{array}$ & Percent \\
\hline Lighting & 5,829 & 2.67 \\
\hline Feed Handling & 64,808 & 29.66 \\
\hline Waste Disposal (Vehs) & 23,345 & 10.68 \\
\hline Waste Disposal (Mach) & 1,586 & 0.73 \\
\hline Water Supply & 5,169 & 2.37 \\
\hline Livestock Handling & 2,547 & 1.17 \\
\hline Space Heating & 5,757 & 2.63 \\
\hline Ventilation & 6,114 & 2.80 \\
\hline Water Heating & 9,737 & 4.46 \\
\hline Milking & 2,711 & 1.24 \\
\hline Milk Cooling & 4,451 & 2.04 \\
\hline Egg Handling & 104 & 0.05 \\
\hline Brooding & 26,679 & 12.20 \\
\hline Fam Vehicles & 36,493 & 16.70 \\
\hline Farm Auto-Livestock & 8,607 & 3.93 \\
\hline Other & 14,592 & 6.67 \\
\hline Tota? & 218,529 & 100.00 \\
\hline
\end{tabular}

The primary energy stream in livestock production is the handling of feed and 1 ivestock $(0.067$ quad per year). The other main energy streams include waste disposal, 0.025 quad; ventilation, milking, and egg handling, 0.014 quad; and transportation at 0.045 quad. The total of these end uses is 0.15 quad, representing $68 \%$ of total livestock production energy use and $11 \%$ of the total energy use in agriculture. This energy information was used to identify the agricultural processes having the most significant energy use. Transportation of crops/ /ivestock on roadways was excluded because these tribological mecharijsms anc energy losses are addressed in separate research for the. Tribology F'rogram ty MTI. In this chapter the main tribological sinks are identified and clescribed, including the mechanisms involved in the sinks and the estimates of direct and indirect energy use in the sinks. 


\section{1 .2 Major Agricultural Processes}

As noted earlier, the two major agricultura processes that consume the most energy are crop and livestock production.

\section{Crop Production}

Two indicators of a historical trend in crof production, human labor per acre and pounds of machunery per acre, are shown in Figure 3.1. Although the exact magnitude of values, such as pounds of machinery used to produce an acre of grain, is uncertatn, the trend has clearly been toward increased mechanization.

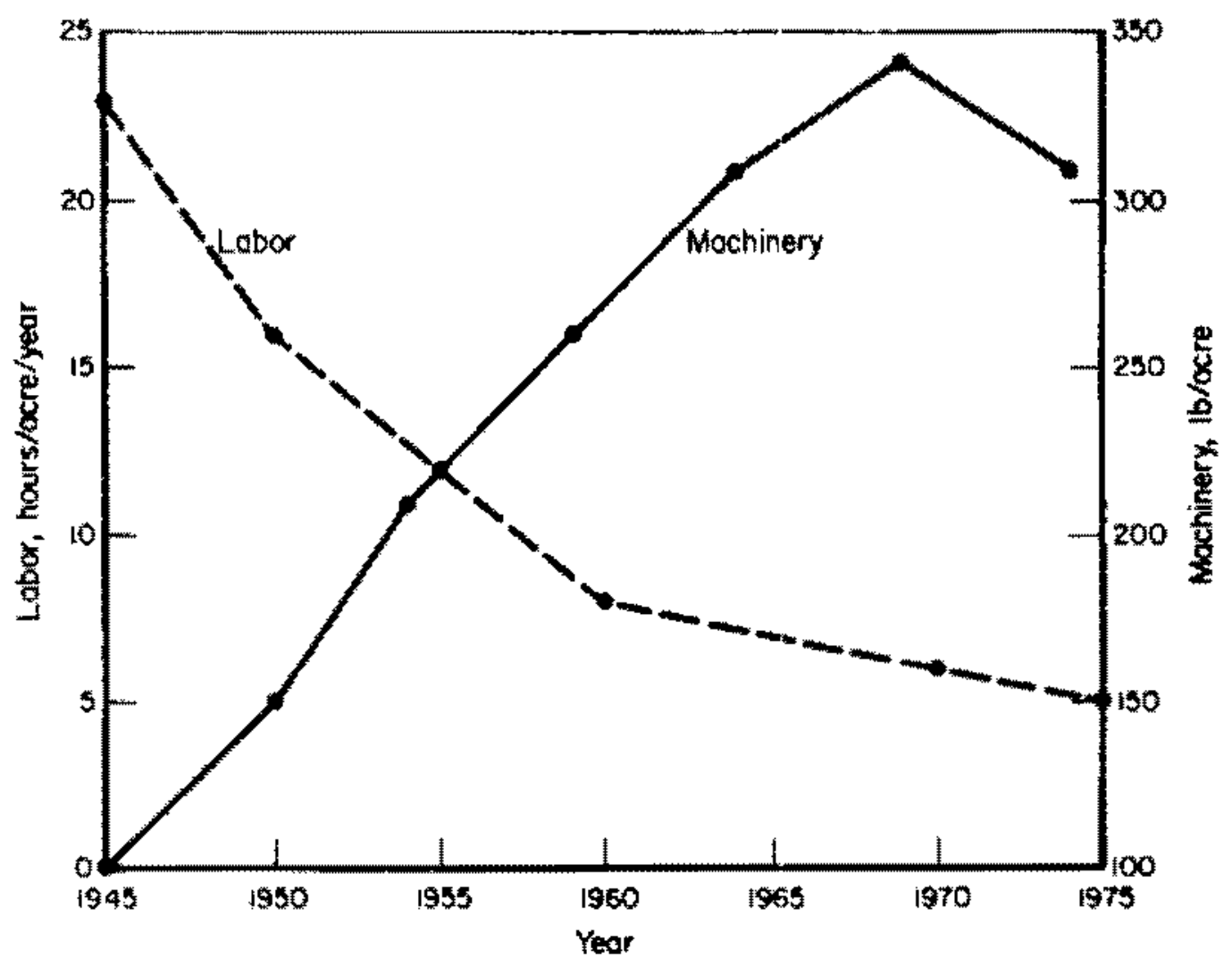

Figure 3.1. Labor and Machinery Inputs for Production of Grain Corn 
Managing machinery costs has become a vital concern of the Anerican farmer. A review of the industry for tribological losses showed that some machinery costs, such as capital recovery and other fixed costs, had been tracked and computed accurately. Machine life expectancies are well established, and fuel and labor inputs to farming can also be predicted with confidence. Repair and maintenance costs, however, are highly variable and are subject to much more speculation in the literature. Various studies have applied statistical analysis to samples as large as 1400 farms in one case and over periods as long as 8 years in another case (Fairbanks, Larson and Chung 1971; Bowers and Hunt 1975; Clark and Johnson 1975; Smith and 01iver 1975; Richardson, Jones and Atwood 1967; Hunt Undated; Holn 1975; Bowers 1975; and Lockeretz 1977). The difficulty remains, however, in determining what portion of machinery failures may be attributed to tribological mechanisms.

The total acreages used in 1983 crop production for various crops are shown in Table 3.4. The farms that produced these crops could be classified in two broad categories. The first category may be described as the family farm, typically ranging in size up to 700 acres. This farm would support several tractors in the 50 to 150 horsepower range. The various pieces of machinery on these farns operate 100 to 500 hours per year (Fairbanks, Larson and Chung 1971; Bowers and Hunt 1975; Clark and Johnson 1975; Smith and 0liver 1975; Richardson, Jones and Atwood 1967; Hunt Undated; Holn 1975; Bowers 1975; and Lockeretz 1977).

The second classification, a corporation farm, encompasses much larger acreages. Hunt (undated) describes a corporation farm as having at least 10,000 acres. This type of farm can support thirty 100-horsepower tractors, or might use fewer but larger capacity tractors (ranging from 150 to 400 horsepower). The various pieces of machinery would aperate about 1000 hours per year.

Up to this point, tractors are the only farm equipment that has been specifically named. Surveys of all farm machinery can easily include close to a hundred distinct items; however, many of the items are very few in number or consume very little energy and therefore have not been included in this tribological energy loss evaluation. 
TABLE 3.4. Crop production Acreages for 1983 (U.S. Department of Agriculture 1983)

\begin{tabular}{|c|c|c|}
\hline $\operatorname{crop}$ & $\begin{array}{l}\text { Area planted } \\
\text { (1000 acres) }\end{array}$ & $\begin{array}{l}\text { Area Harvested } \\
(1000 \text { acres })\end{array}$ \\
\hline Corn (all purpose) & 82,000 & 73,000 \\
\hline Hay (all) & - & 61,000 \\
\hline Wheat & 87,000 & 79,000 \\
\hline Soybeans & 72,000 & 71,000 \\
\hline Cotton & 11,000 & 9,700 \\
\hline Fruft & $=-$ & -- \\
\hline Sorghum (grain) & 16,000 & 14,000 \\
\hline Vegetables & 2,200 & 2,200 \\
\hline Rice & 3,300 & 3,300 \\
\hline Tobacco & $\cdots$ & 910 \\
\hline fats & 14,000 & 11,000 \\
\hline Parley & 9,600 & 9,100 \\
\hline Sugar cane & 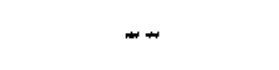 & 760 \\
\hline Sugar beets & 1,100 & 1,000 \\
\hline peanuts & 1,300 & 1,300 \\
\hline
\end{tabular}

The initial step in fdentifying the major tribology sinks for crop production was to prioritize U.S. crops by energy use. The processes and nachines corresponding to these crops were then examined for tribological eneryy sinks. Figure 3.2 quantitatively compares the energy inputs for the crops. The data indicate that the top four crops, corn, ray, wheat, and soybeans, constitute 53 of of the total energy consumed in crco production (Industrial Energy-Use data Book 1974). The energy consumed by these crops suggests that the varlous processes used in rasing these crops should be emphasized in consitering tribological energy sinks. The machinery used on these crops is also used for many of the smaller volume crops. Therefore, the study of the top four crops incorporates technologies of most crops produced.

Table 3.5 shows, according to the production processes, the machinery used in crop production. The table shows that even over the wide variety of crops, a few machines are comon to particular process. Column two of the table, 


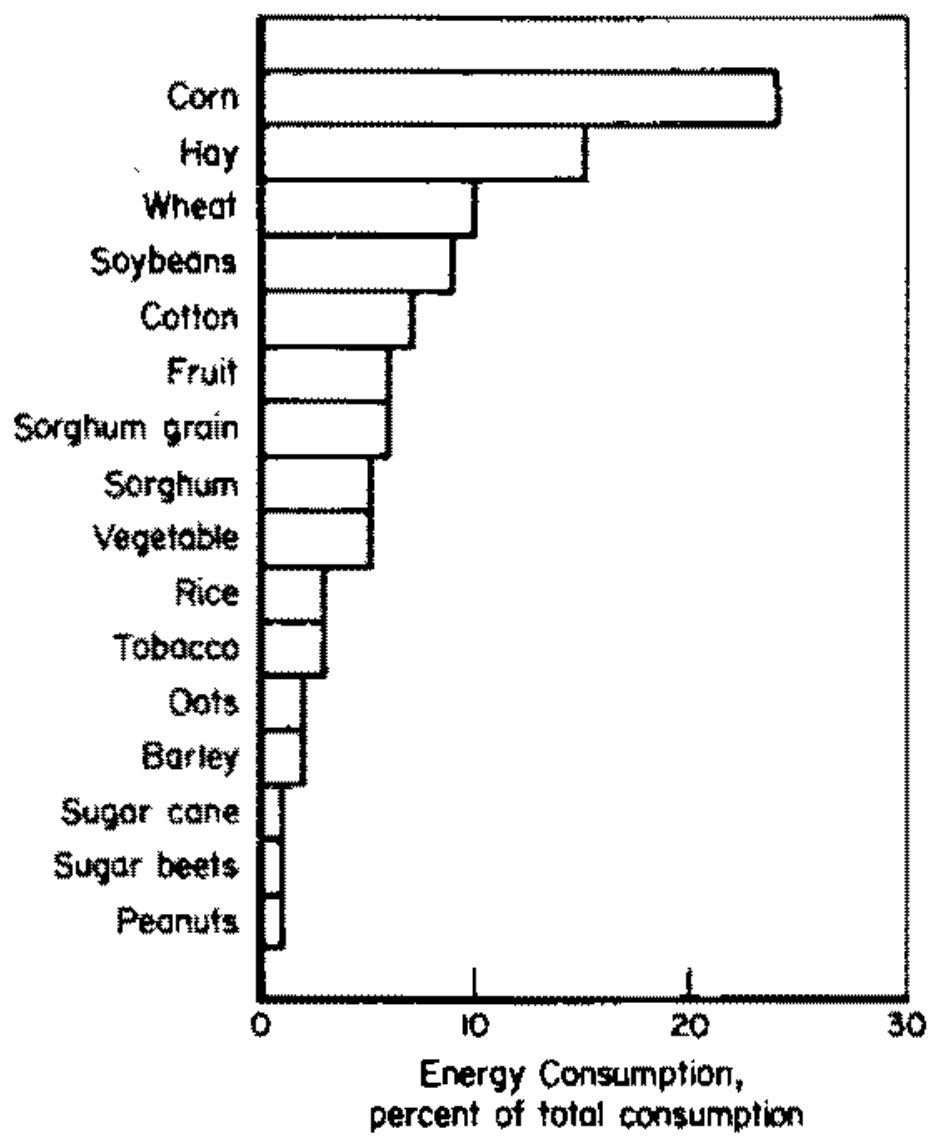

FIGupe 3.2. Energy Consumption in Crop Production by Respective Crop

which represents the tllage process, shows that seedbed preparation is performed by a sactor pulling one or more of a variety of implements. The only notable exceptions are hay and frut neither of whot require prinary tillage. Colum three of Table 3.5, the process of planting, shows that row crop planters and grain arills are adapted to plant nost crops. The only exception in a major crop is the planting of some small grain seeds (such as hay) with broadcasters.

Irrigation (colum four) is applied to varying extents according to crop type and ineteorological location. Centrifugal pumps are used primarily to drive one of five major irrigation system types.

Several special-purpose machines are used in harvesting specific crops (column five), such as sugar beet diggers and blueberry pickers. However, a 
TABLE 3.5, Machinery Used in Crop Production

\begin{tabular}{|c|c|c|c|c|c|}
\hline $\operatorname{srop}$ & fillage $(a)$ & Plantiag & 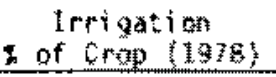 & Hervest & Transegortation \\
\hline Corn & Tactor and 4 ab & Rew Planter & 13 & Conbine with corn head & $\begin{array}{l}\text { Conveyors, augers, woons } \\
\text { arat trucks }\end{array}$ \\
\hline Hay & Infroglent & $\begin{array}{c}\text { Tractof atsk and } \\
\text { broadeaster }\end{array}$ & 22 & $\begin{array}{l}\text { Mawer, condit ofuts hay } \\
\text { rake, baler }\end{array}$ & frontend loaders and chloyors \\
\hline Heat & Tractor and $A \ldots$ & $\begin{array}{l}\text { Grain arill (xos) } \\
\text { troadcaster (10) }\end{array}$ & 6 & Conbi ne wh grain head & Simi tar to tarn \\
\hline Soybeans & Iractor and $t-f$ & $\begin{array}{l}\text { Prow planter and } \\
\text { grain drillil }\end{array}$ & 2 & $\cdots$ & simflat to cortol \\
\hline Cotson & Tractor antal & Row platater & 37 & $\begin{array}{l}\text { cambine (50) hantuptex and } \\
\text { custom machines }(50) \text { (1) }\end{array}$ & Simation to hay \\
\hline Frititit & -- & $-\ldots$ & 66 & 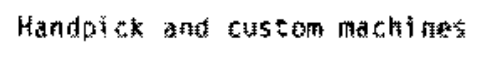 & $\begin{array}{l}\text { Conveyors, wates atd } \\
\text { trucks }\end{array}$ \\
\hline Sorghum & Yactor and $A-6$ & singlar to conta & $1 F$ & Conbine with com lead & Similar to tom \\
\hline Vequetryes & Tractor and ${ }^{*}+\mathrm{F}_{3}$ & Varied & $5 \%$ & 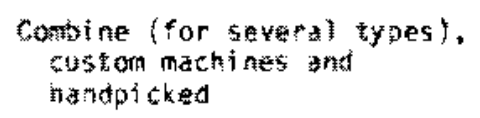 & $\begin{array}{l}\text { Conveyors, wagons and } \\
\text { twates }\end{array}$ \\
\hline Rice & Tractor and $A-G$ & 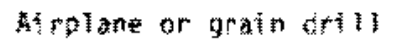 & 100 & Combine & Similar to torn \\
\hline robacco & Tatater and $A=6$ & Tounsplanted & 13 & Const he and handpickec & -- \\
\hline $0 \mathrm{at}: \mathrm{s}$ & Fractor bne $\mathrm{A}-\hat{\mathrm{G}}$ & $\begin{array}{l}\text { Grain drul and } \\
\text { broddedster }\end{array}$ & 2 & Combine & Simhlar to corn \\
\hline Barley & Tractor and & $\begin{array}{l}\text { Grainatll and } \\
\text { broatcaster }\end{array}$ & 22 & fonting & Simtlar to corr \\
\hline stomar cane & Tratar and $A-G$ & Hster & Wh & Topper, watower & front-end loader and trucks \\
\hline Sagar beets & usactor and $\mathrm{A}-6$ & lister & 端 & sitgar beet harvester & $\begin{array}{l}\text { Conveyors, wagons ant } \\
\text { erateots }\end{array}$ \\
\hline Peanats & Tract of and $A+G$ & Row olantar & 23 & fompine & $\begin{array}{l}\text { Conzeyofs, wagons and } \\
\text { tructs }\end{array}$ \\
\hline
\end{tabular}

(1) Entries th the tolunn are coded as follows:

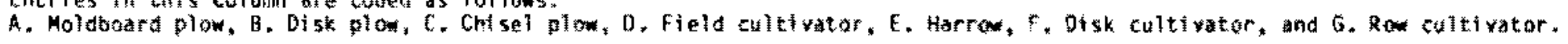


tary high percentage of crops (71) are harvested with a combine. The combine * -11 be described and 111 ustrated in a later section where its tribological components are examined in detail. The only major crops not harvested with a zombine are hay and forage. Hay involves an almost entirely different process if mowing, raking, and baling. Forage harvest is performed with a machine called a "forage harvester."

Crop handling and transportation is the final category included in Table 3.5. The mathinery comnonly applied are augers and conveyors, which load xagons and trucks for transportation to the first stations of the food procesing induketres.

In simary, crops fit very well into the classiflcation scheme used, with ;he excepion of hay, which must be considered separately in nearly all steps $\mathrm{J}^{-}$crop production.

Livertock Production

The anergy used in livestock production is typically less than one-fifth $J^{2}$ tot $\hat{c}_{1}$ energy used in agriculture. Of the total energy input, beef and dairy attle consumed $65 \%$, hogs 17\%, and chickens 14\%. In 1982, the U.S. Department of Agriculture (1983) reported that the livestock produced constituted 115 million cattle, 53 millton hogs, and 246 million chickens. As with crop production, the various types of livestock were examined for machinery required in the various producton processes.

In Table 3.6 the livestock production processes that were found to be subject to tibological nechanisms are listed as column headings. The row headings are the various types of livestock produced: catte, sheep, hogs, and lurkeys and chickens. The table shows that even over the wide wariety of livestock, a few machines are common to a particular process.

Automatic systems often feed and water livestock. Gralt and other solid food concantrates are carried from sitos and storage bins directly to the feeding troughs through conveyors and augers similar to those described in crop production. Water is also supplied by automatic systems. Blowers of various sorts are used to distribute bedding, to control temperature, and to dust 
TABLE 3.6. Machinery Used in Livestock Production

\begin{tabular}{|c|c|c|c|}
\hline Lyestock & Feedind & Nurturing & Waste Remoyal \\
\hline Bete Dairy catth & $\begin{array}{l}\text { Mechanteal bale nanding, } \\
\text { silo unloader, grain } \\
\text { grinding \& minging. } \\
\text { automatic waterers }\end{array}$ & $\begin{array}{l}\text { Blowers for bedding distri- } \\
\text { bution o terperature } \\
\text { control }\end{array}$ & $\begin{array}{l}\text { Tractor loaders, drat } \\
\text { chatns, pumps, } \\
\text { conveyors }\end{array}$ \\
\hline Sheep & $\begin{array}{l}\text { Snall; many sheep are } \\
\text { grazed on oper pasture }\end{array}$ & $\begin{array}{l}\text { Tick control: dusting } \\
\text { blowers and pumps for } \\
\text { sheep dip baths }\end{array}$ & $\ldots$ \\
\hline Turkeys \& Chickens & $\begin{array}{l}\text { Automatic feed conveyurs } \\
\text { and atutomatic waterers }\end{array}$ & $\begin{array}{l}\text { Blowers for temperature } \\
\text { conterol }\end{array}$ & $\begin{array}{l}\text { Wet and dry waste renoval } \\
\text { va punps \& conveyors }\end{array}$ \\
\hline
\end{tabular}


arimals for insect control. These blowers commonly operate in a hot, dusty ervironment, wich causes associated bearing fallures.

In the third process column of Table 3.6, two concepts of waste removal are shown. In some areas, such as livestock loafing sheds, manure is sometimes allowed tc accumulate and is then removed with a tractor loader. In other iases, such as high production chicken farms, the waste is constantly collected ard disposed of by hydraulic or dry conveyors.

\section{MAJOR TRIBOLOGICAL SINKS IN AGRICULTURE}

Table 3.7 summarizes the tribological losses for all crop production as froken down into processes. The components at wich the losses occur are also briefly irdicated in the table. The processes by which these values were lerived are briefly described in the following sections.

\subsubsection{Sources of Tribological Losses}

In tris section, aspects of the agricultural processes that affect tribocgical losses and the sources of these losses for crops and livestock produczion are discussed. The discussion is divided by process type and focuses on fiecific components of agricultural machines that suffer significant friction zid wear. The processes discussed include tillage, planting, fertilizer and henical application, irrigation, harvesting, crop handing and transportation, the livestock production.

\section{Tillege (including cultivation)}

Thlage is generally divided into several categorifs, with the following defintitions:

1. prinary tillage - serves to break sod, turn under restdue, Kill weeds, and loosen the plow layer

2. secondary thllage - any working of the seedbed up to the point of planting, which serves to pack or loosen the seedbed, break clods, kill weeds, and smooth the seedbed

3. cultivation - after planting, primarily accomplishes weed control and breaks the ground crust to improve water absorption characteristics. 
TABLE 3.7. Sumnary of Tribological Losses in Crep and Livestock Production Direct Losses

\begin{tabular}{|c|c|c|c|c|}
\hline Process & Machine & \multicolumn{2}{|c|}{ Site of Direct Loss } & Direct Loss (Btu) \\
\hline Thllage & Implements $(a)$ & \multicolumn{2}{|c|}{ Parts that engage soil } & $5.7 \times 10^{12}$ \\
\hline Planting & Planters & \multicolumn{2}{|c|}{ Parts that engage: soil } & $1.3 \times 10^{12}$ \\
\hline Irrigation & Pumps & \multicolumn{2}{|c|}{ Impeller } & $1.0 \times 10^{12}$ \\
\hline \multirow[t]{3}{*}{ Transportation } & \multirow{2}{*}{$\begin{array}{l}\text { Crop Conveyors } \\
\text { Feed Conveyors }\end{array}$} & \multicolumn{2}{|l|}{ Bearings } & $2.9 \times 10^{10}$ \\
\hline & & Bearings & & $1.2 \times 10^{10}$ \\
\hline & \multicolumn{3}{|c|}{$\frac{\text { Indirect Losses }}{\text { Component }}$} & \\
\hline Process & Machine & $\begin{array}{l}\text { Compon } \\
\text { Nanee }\end{array}$ & Material & $\begin{array}{l}\text { Indirect Loss } \\
\text { (annual use, 1983) }\end{array}$ \\
\hline \multirow[t]{3}{*}{ Tillage } & \multirow{3}{*}{$\begin{array}{l}\text { Implenents (a) } \\
\text { Tractor }\end{array}$} & Tool points & Steel & $4.5 \times 10^{8}$ pounds \\
\hline & & Tire & Rubber & $4.6 \times 10^{7}$ pounds \\
\hline & & Lubricant & Petroleum & $2.7 \times 10^{7}$ gallons \\
\hline Planting & Planters & Tool points & Steel & $1.1 \times 10^{8}$ pounds \\
\hline \multirow[t]{5}{*}{ Harvest } & Combine & Bearings & stee] & Not quant iffed \\
\hline & & Chains & Stee? & Not quantified \\
\hline & & Belts & Rubber & Not quantified \\
\hline & & $\begin{array}{l}\text { Thresher } \\
\text { parts }\end{array}$ & Steel & Not quantified \\
\hline & & $\begin{array}{l}\text { Header } \\
\text { parts }\end{array}$ & Steel & Not guantified \\
\hline
\end{tabular}

(a) Listed in Table 3.5 .

The number of trips over the field to accomplish each of these goals is important because each additional trip contributes to the direct energy loss associated with tillage. The number of trips varies with crop type and soll condition at the time of plowing; however, an average schedule that was used in the direct loss calculation is given in Table 3.8 for conventional tillage, minimum tillage, and no tillage. The minimun tillage schedule was used in the 
TABLE 3.8. Trips Over the Field (Phillips and Young 1977)

\begin{tabular}{|c|c|c|c|}
\hline & Conventional Tillage & Minimum Tillage & No Tillage \\
\hline Plowing & 1 & 1 & 1 \\
\hline Disking & 2 or more & 0 or more & 0 \\
\hline planting & 1 & 1 or 0 & 1 \\
\hline Spraying & 0 or more & 0 or 1 & 1 \\
\hline Cultivating & 2 or more & 1 or 2 & 0 \\
\hline Harvesting & 1 & 1 & 1 \\
\hline rotal Trips & 7 or more & 4 or 5 & 4 \\
\hline
\end{tabular}

calculat ons and reduces the number of trips over the field to five (two less than conventional tillage). In either case, the machinery used for each trip is a tractor and one or more implements.

Tractors. In 1983 there were 4,600,000 tractors (exclusive of steam and garden type) on U.S. farms (Department of Agriculture 1983). They comprised :78 mi11 on tractor horsepower, powered by gasoline, diesel fuel, and propane. The types and sizes of tractors can be classified in many ways; however, the only distinction necessary for this study is the size classifications:

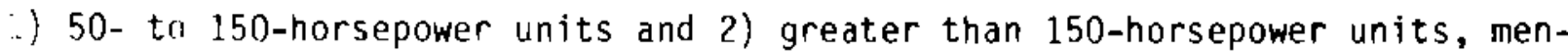
tioned earlier. Tillage operations place the highest power demands on the tractor, and subsequently, tillage is the critical factor that dictates the 1:ractor engine size required. Most (perhaps $80 \%$ ) of this power is transferred through the tractor tires to the tillage implement. It is at this tire-toearth interface that the single most significant tribological loss, excluding the engines, occurs in tractors.

Agricultural tires typically operate at high slip percentages of $10 \%$ to 20\% (Holn 1975). (Slip is relative motion between the tire and ground). The transfer of large amounts of power at high slip requires that the tire be replaced or retreaded about every 1000 to 2000 hours of operation. For this study, replacement of two rear drive tires sized to fit a 60-horsepower tractor was assumed (the average computed from the agricultural census quoted above and also indicated in the literature, although not exhaustively investigated). Used in conjunction with the total number of annual operating hours extracted 
from the data of Table 3.4, tractor tires result in an indirect loss of $4.6 \times$ 107 pounds of rubber per year.

The power take-off drives (PTOS) on tractors were also reviewed. PTos are usually extensions of the drive systen that provida power for stationary machines such as pumps, sows, mowers, etc. The PTIs, while identified as a medium wear item, account for a small tribological sink, and mininal wear rate information was found. Therefore, they were not included in the final analysis.

Another indirect loss, lubricant, was calculated for our average size sractor based on manufacturers' recomended maintenance schedules and a discussion with a farner. This loss magnitude is indicated in Table 3.7 .

Tillage Implements. Tillage has long been recognized as an energy sink. Research of sone tillage-related technologies still under development was iniw thated as early as 1960. For this study, the voluminous research literature on the tribological mechanisns of the tillage process was reviewed. A composite of the findings commonly agreed upon is used for this discusston.

A plow must "scour" to operate properly, In technical terms, this phem nomena implies that the best performance occurs when the plow is smooth. The presence of any roughening, such as "rust, greatly increases the draft requirements. Sone work has been done to attempt to instill lubricated wear. The abrasive wear depends prinarly on the strength and hardness of the plow"s metal in its maximum work-hardened state, which results fron the tilling prom cess. The effects of these tribological influences are discussed below.

The major types of tillage equipment discussed in this study are listed in Table 3.9. Thirty to sixty percent of the draft (or pulling power) requirement of thlage implements is required to overcome the parasitic forces that arise difectly from friction of the implement engaging the worked material. Because of the high draft forces required to till earth, this amounts to a significant tribologital energy sink, both directly through friction and indirectly through wear. In Table 3.9 , the total energy inputs per acre are reported. Frictional loss values were given in several references and were also calculated from soll thllage dynamics taken from text on principles of fam nachinery. The values 
TABLE 3.9. Major Types of Tillage Implements Considered for Tribological Losses

\begin{tabular}{|c|c|c|c|c|}
\hline Implement & $\begin{array}{c}\text { Energy } \\
\text { Input } \\
\text { (Btu/acre) } \\
\end{array}$ & $\begin{array}{l}\text { Direct Tribo- } \\
\text { logical Loss } \\
\text { (Btu/acre) } \\
\end{array}$ & $\begin{array}{l}\text { Indirect Tribo- } \\
\text { logical Loss } \\
\text { (1) steel/acre) }\end{array}$ & $\begin{array}{l}\text { Description } \\
\text { and conments }\end{array}$ \\
\hline Moldboart plow & 62,000 & 19,000 & 0.11 & $\begin{array}{l}\text { Plow } 8 \text { inches } \\
\text { deep with } \\
5 \text {-bottom plow }\end{array}$ \\
\hline Disk plow & 62,000 & 19,000 & 0.18 & 5-24 in. disk \\
\hline Shisel plow & 41,000 & 12,000 & $\cdots$ & $16 \mathrm{ft}$ wide \\
\hline $\begin{array}{l}\text { Field } \\
\text { cultivator }\end{array}$ & 20,000 & 6,100 & $-\infty$ & $16 \mathrm{ft}$ wide \\
\hline $\begin{array}{l}\text { Spring tooth } \\
\text { harrow }\end{array}$ & 8,700 & 2,600 & -- & $16 \mathrm{ft}$ wide \\
\hline Disk harrow & 18,000 & 5,500 & $0.6 ?$ & $16 \mathrm{ft}$ wide \\
\hline $\begin{array}{l}\text { Row crop } \\
\text { cultivitor }\end{array}$ & 15,000 & 4,600 & 0.12 & 6 rows \\
\hline Rotary hoe & 7,100 & 2,100 & -- & $24 \mathrm{ft}$ wide \\
\hline $\begin{array}{l}\text { Powered rotary } \\
\text { tiller }\end{array}$ & -- & -- & - & $15 \mathrm{ft}$ wide \\
\hline
\end{tabular}

(a) Smith and 01iver (1975).

were found to agree (Kepner undated; Shipper et a1. 1980; and Culpin 1976). Although the draft requi rements for different implements vary, the percent of araft due to friction consistently ranged from $30 \%$ to $60 \%$. The second column of Table 3.9 is the tribological losses calculated for each implement using the sonewhat conservative figure of $30 \%$ of the total energy input for each implement type.

In Table 3.9, a rate is also given for the indirect losses of the implenent's replacement parts that engage the worked material. Examples of such parts include plowshares, plow moldboards, plow landslides, disks, tapered roller bearings, which support disks, tines for chisel plows and field cultivators, and points for subsoilers and row cultivators. These parts are made from carbon steels, alloy steels, and cast iron. An approximate life of 100 to 150 hours for disks and plowshares was calculated. Assuming similar life for 
all of these components that engage the worked material, the associated weights of the components were then used to arrive at an approximate value of pounds of metal per acre tilled. Because of variations in the soil composition and tilling conditions, more accurately estimating the wear rate across the nation is difficult. However, this conservative estimate will show the magnitude of the metal involved in what farmers consider routine maintenance items.

\section{Planting}

Table 3.10, which lists major types of planting implements considered for losses, has been constructed similarly to Table 3.9 on tillage equipment. Planting is very similar to tillage operations froin a tribological viewpoint. One component of the draft requirement results from friction forces and creates a direct loss. The furrow in which the seed is planted is opened with disk and cultivator tool points, so there is an associated wear loss, just as in tillage. The only large difference is functional, in that a planter simultaneously places the seed in the ground and often fertilizes while it performs a light cultivation process.

Fertilizer and Chemical Application

Fertilizer and chemical equipment has been included only because they comprise a major percentage (up to 50\%) of the total agricultural energy use. The tribological energy associated with applying fertilizers, however, is generally quite low in comparison to other tillage operations. Therefore, the

\section{TABLE 3.10. Major Types of Planting Implements Considered} for Tribological Losses

\begin{tabular}{|c|c|c|c|c|}
\hline Implement & $\begin{array}{c}\text { Energy } \\
\text { Input } \\
\text { (Btu/acre) } \\
\end{array}$ & $\begin{array}{c}\text { Direct Tribo- } \\
\text { logical Loss } \\
\text { (Btu/acre) }\end{array}$ & $\begin{array}{l}\text { Indirect Tribo- } \\
\text { logical Loss } \\
\text { (lb steel/acre) }\end{array}$ & $\begin{array}{l}\text { Description } \\
\text { and Comments }\end{array}$ \\
\hline $\begin{array}{l}\text { Row crop } \\
\text { planter }\end{array}$ & 17,000 & 5,100 & 0.12 & $12 \mathrm{ft}$ wide \\
\hline Grain drill & 12,000 & 3,600 & 0.26 & $9-13 \mathrm{ft}$ wide \\
\hline Broadcaster & Small & Sma $1 !$ & -- & -- \\
\hline
\end{tabular}

(a) Taken from Smith and 01iver (1975). 
energy is mainly required in the manufacture of the fertilizer, which is discussed in Chapter 5.0 on the chemical industries.

\section{Irrigation}

In 1974 about 35 million acres were irrigated in the U.S. using on-farm pumped water, for a total of 69 million acre-feet of water. This pumping required an estimated 260 trillion Btu, or about $21 \%$ of the total energy consumed in farm production (Holn 1975). By 1975, 54 million acres were being irrigated (Lockeretz 1977). These data indicate the importance of irrigation in the general agricultural energy picture. The scale of importance is reduced considerably, however, when the component attributed to tribological losses is extracted from these data.

Irrigation is commonly accomplished with one of the following systems: surface irrigation (open ditches), a solid-set sprinkler, a big gun sprinkler, or a center-pivot sprinkler. Culpin (1976) indicated that the center-pivot system consumes significantly more energy than the other types combined. This pressurized sprinkler system (approximately 200 feet of head pressure) requires much more pumping energy than surface irrigation.

Centrifugal pumps have been found to be particularly well suited for irrigation applications such as the center-pivot system. Efficiencies for irrigation pumps were reported as high as $75 \%$, and an average value was estimated as $60 \%$ by one irrigation engineer (Lockeretz 1977). Of the $40 \%$ inefficiency, $1 \%$ or less may be attributed to tribological causes. One percent of the national use given above then amounts to a sizeable one trillion Btu per year. However, reducing a component of the inefficiency, which is already less than $1 \%$, could prove difficult.

Harvesting

The two types of equipment described in this process are combines and hay and forage harvesters.

Combines. The modern combine is a complex machine, performing five basic crop harvesting functions: 
1. cutting and feeding

2. threshing

3. separating

4. cleaning

5. storage and handling.

Many combines are self-propelled, which adds to the complexity and embodied materials of the engine, power train, electrical, and hydraulic systems. As was noted in the previous classification of farm machinery, the combine is used to harvest many types of crops. The combine is adapted for use with various crops mainly by selecting the harvesting attachment mounted on the front. Figure 3.3 shows a modern self-propelled combine with one of the two basic types of heads--a cutting platform for gathering small grains. The other type of head is designed for row crops such as corn. The tribological losses in the two types of heads are slightly different, although on the same order of magnitude. The tribological losses for the main body of the combine, which performs functions 2 through 5 listed above, are similar for all crops.

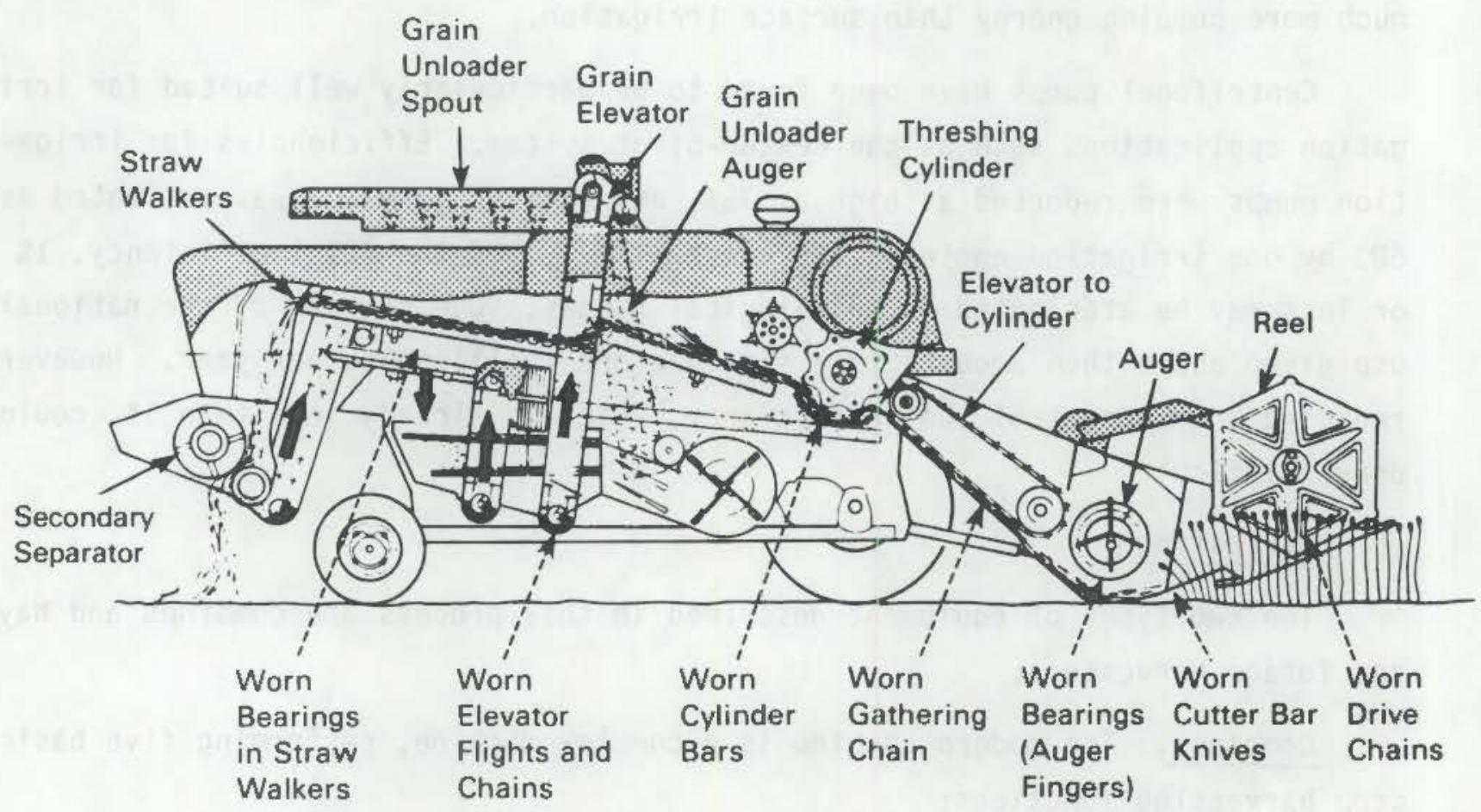

FIGURE 3.3. Grain Combine Harvester with Example Tribological Sites Indicated 
Sourses of tribological losses in the combine are indlcated in Figure 3.3 by the dotted arrows. Indirect losses, small in magnitude but persistent in owcurrence, characterize the machine. Conversations with farmers indicated that stocxs of these high-replacenent ttems, such as bearings, are kept on hand and routinely replaced. By correlating replacement schedules and machine capacities, each of the tribological components, listed in Table 3.11, was estimated to be replaced at least once every 1000 acres harvested, This est m mate is tenuous because of 1) the many different parts and 2) the large differences in the replacement rates of these parts. For example, a typical combine has 40 different bearings, 18 different drive belts, and more than 10 chains. The belts are replaced every one to three years, bearings every one to two years, the cunveyors every three years, and the chains every two to three years. The indirect tribological losses for each part are minimal, but the cumulative loss is whth review. This review, however, would require a detailed analysis to develop reasonable estimates of energy and material losses; such an analysis was beyond the resources awalable for this review, although such a review will be recomnended for later consideration.

lay and Field Forage larvesters. The harvesting of hay is different from the harvesting of grain crops in that the plant stalk is part of the desired comflodity. The hay harvest consists of mowing the crop, raking the crop into windrows, conditioning the hay, and finally baling the hay for transport and storage. Conditioning the hay an refer to any of several processes such as turning the windrow, bruising the hay with rollers, or aerating the windrow to speed drying. Table 3.11 concentrates on the machines that cut the crop and experience wear as a result.

sonetimes the entire plant of various grain crops, suth as corn or soyheans, is harvested by chopping the crop into small pleces called silage. shage is stored green (with a relatively nighmoisture content) in silos where " ferments into a desirable feed for livastock. An indirect tribological loss

$\$$ associated with the various arrangements of choppers and stredders in field forage harvesters. The tribological machine components are listed in able 3,1.1. 
ThatE 3.11. Major Types of Harvesting Machinery Consitered for Tribologitcal Losses

Conbined Crops

\begin{tabular}{|c|c|c|c|}
\hline \multirow{2}{*}{$\begin{array}{l}\text { Gathering } \\
\text { Head Type }\end{array}$} & \multicolumn{3}{|c|}{ Tribological Machine Element } \\
\hline & Name & Material & Number of Parts \\
\hline Grain & $\begin{array}{l}\text { Cutter har, } \\
\text { knives \& guards }\end{array}$ & Steel & 36 knives and guards \\
\hline corn & $\begin{array}{l}\text { Shapping plates, } \\
\text { trash knives, } \\
\text { gathering chains }\end{array}$ & Steel & $\begin{array}{l}\text { Co } 4 \text {-row head: } 8 \text { plates } \\
\text { a } 3-4 \text { 1b/glate } \\
\text { E chains } 5 \text { ib/chain }\end{array}$ \\
\hline Either & $\begin{array}{l}\text { Drfe \& elevator } \\
\text { chain, thresher } \\
\text { parts, } \\
\text { bearings } \\
\text { Drive belts }\end{array}$ & Steel & $\begin{array}{l}12-24(1-2 \text { in.) ball } \\
\text { and plain type } \\
6-18(3 \mathrm{ft}) \text { y-belts }\end{array}$ \\
\hline
\end{tabular}

Hay and Forage Crops

\begin{tabular}{|c|c|c|c|}
\hline \multirow{2}{*}{$\begin{array}{l}\text { Implement } \\
\text { Narne }\end{array}$} & \multicolumn{3}{|c|}{ Tribological Machine Element } \\
\hline & Name & Material & - Number of Parts \\
\hline \multicolumn{4}{|l|}{ Mower } \\
\hline $\begin{array}{l}\text { Flail type } \\
\text { Cutter har }\end{array}$ & $\begin{array}{l}\text { Flails, } \\
\text { Knives \& guards }\end{array}$ & Steel & $\begin{array}{l}30-60 \text { flails } 1.51 \mathrm{~b} / \mathrm{b} \text { lade } \\
36 \text { knives and guards }\end{array}$ \\
\hline Bater & $\begin{array}{l}\text { Ram knife, } \\
\text { twine knife \& } \\
\text { hay gathering } \\
\text { fingers }\end{array}$ & Steel & $131 \mathrm{ade}(24 \times 3 \times 0.25 \mathrm{in})$. \\
\hline $\begin{array}{l}\text { Forage } \\
\text { harvester }\end{array}$ & $\begin{array}{c}\text { Flails choppling } \\
\text { cylinder blades }\end{array}$ & Steel & $\begin{array}{l}30-60 \text { flails } 1.51 \mathrm{~b} / \mathrm{blade} \\
8 \text { blades }(12 \times 3 \times 0.25 \mathrm{in} .)\end{array}$ \\
\hline
\end{tabular}

(a) Miscellaneous hay conditioning equipment that was discounted includes tedders, turners, crimpers, and rakes. These items accounted for mi nimal tribological sinks and were less commonly used.

\section{Crop Handling and Transportation}

Gratn crops are handled with augers and conveyors. The conveyors may be of the chain, flight, belt or bucket type. The augers and conveyors are used to move crops onboard the harvester and from the harvester to trucks or wagons for transport to treatment or storage stations. At storage stations, such as 
slos, the crop is often handled twice by an auger or conveyor, once to lod the silo rom the top and once again at the silo unloader.

A diect tribological loss is associated with friction in the conveyor pdlleys, friction of the belt or chain riding over the pulleys, and skirtboard fuction the conveyor or conveyed material. The amount of direct energy luss to these interfaces, excluding the power required to elevate the material, 7as been astimated by applying formulas published by the Conveyor Equipment Anufaturers Association (197). Parameters for the calculation were taken fron specifications for an elevator selected from the Implement and Iractor Red Book (.983). A few of the nominal parameters used in the calculation are listed in Table 3.12 .

The losses ranged from $4 \%$ to $20 \%$ of the drive notor power. Each of the crops in lable 3.4 was assunet to be conveyed once under the typical conditions given atowe. Therefore, losses in the percentage of crops conveyed by ager are assumed to be as great as those of a conveyor. The total weight of conveyed material was calculated by associating corresponding average densties (1).S. Department of Agriculture 1983) with each of the crops of Table 3.4* The direct tribological losses calculated under these assumptions for conveyance wera $2.9 \times$ in 10 bu.

\section{Lyestock Production}

The tribological losses in livestock production are snaller than some of the previously considered industrial areas. Livestock mainly adds another componant to the sum of losses attributed to conveyance systems and pumps.

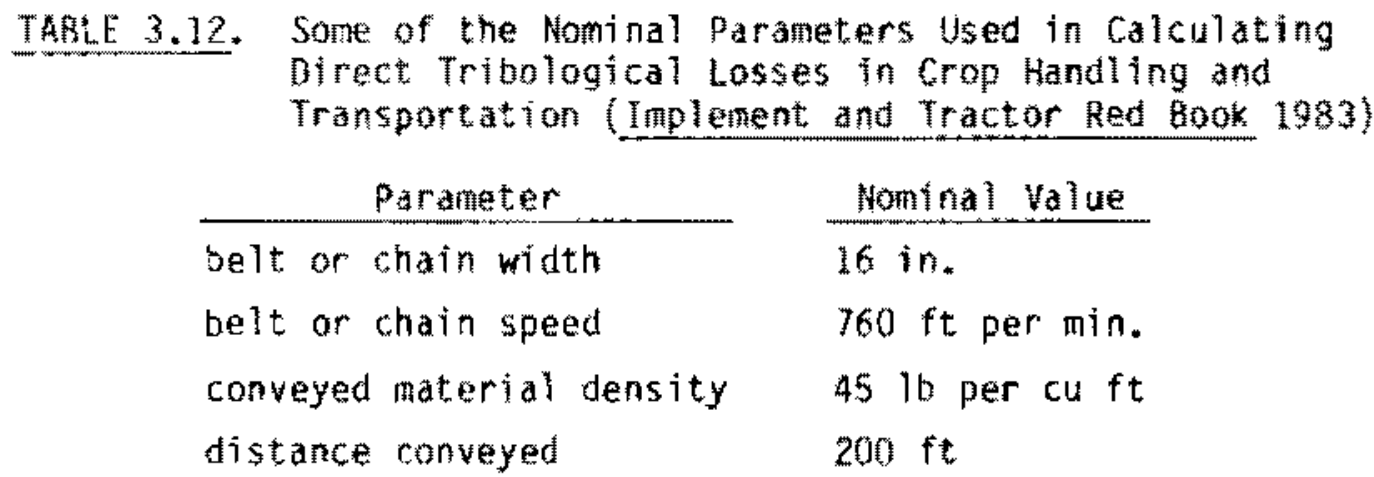


For example, a milk cow requires 30 gallons of water per day--15 gallons for drink, and 15 gallons for cleaning and thlk cooling (culpin 1976). Catcle not in milk production required only 10 gallons per day. The national average milk cow feed ration was reported to be 5280 pounds per year.

Using the more conservative value of 10 gallons of water per day the reduced requilements of calves and increased requirements of milk cows balance out somewhat), the total water requirement that must be punped for cattle alone is $4.2 \times 10^{11}$ gallons per year. A tribological loss is associated whth this pumping requirement; however, as noted before, it is small.

Calculating the feed conveyance requiremen: using the national average given for a milk cow (possibly slightly higher than for cattle not in milk production) leats to $6.1 \times 10^{11}$ pounds per year for all cattle. Recause the conveyance systems are very similar (sonetimes identical) to those used in crop production, the tribological losses in these units were calculated similarly. This leads to a direct loss of $1.2 \times 10^{10}$ Etu, whe largest direct tribological energy loss detected in livestock production. This figure is somewhat conservative in that it does not include conveyance for waste removal from the average cow.

\section{2 .2 A Tribological Perspective on Crop and LIvestock Production}

Tllage is a large sink of direct tribologlcal energy losses because of parastic friction at the working tool interfaces. Harvesting contains significant indirect tribological losses because of whe considerable twomody and three-body abrasive wear in the combine"s many mechanisms.

Ways to reduce these losses have been researched. Antifriction coatings have been successfully applied and found to reduce draft requirements by as much as 30\% (Wismer et al. 1968). Problens with this technology unclude its high cost and high wear rate. Research is currently being performed to develop abrasion-resistant polymers that will replace current antifriction coatings at less expense.

Fluid lubrication has been applied successtully at the tillage interface (Schafer et al. 1979). Three percent polymer in water solutions is metered to 
plow interfaces through ports in the moldboard. In addition to draft reductions of 10 to $30 \%$, it is possible to plow sone acreages previously untillable because of the soil's adhesion characteristics.

Vibration of tillage toolpoints has been under investigation for several years as athod to lower the friction force at the tool-to-soil interface (Wisner et al. 1969). Sone recent investigations that carefully control the direction and nature of the driving ingulse are experiencing success. Technological obstacles include large power consumptions, noise, and vibration.

Transfer of power to the thllage implement via mechanisms other than the tractor tires is being considered to bypass the associated inefficiencies (Hendrick 1980). Rotary tillers, driven by an auxiliary driveshaft from the tractor engine, are an accepted part of current llige technology. Drawbacks or linitations of this approach center on overtilling. Some researchers and farmers believe that rotary tillers high energy input to the soll destroys important soil structure.

No significant tribological activities were identified in livestock procuction. Conveyors, pumps, blowers, and motors were all present in livestock froduction, but the tribological losses associated with them are small.

\subsection{SUMMARY OF TRIBOLOGICAL SINKS UN AGRICULTURE}

The most significant tribological sinks in agriculture are in soil cultivation and crop production. The sinks that merited analys is are as follows:

- cror production

- tillage

- irrigation

- Eransportation

- planting

- harvesting

- livestock production

- feeding and watering

- waste removal

- nurturing. 
Several agricultural end uses that have significant energy consumption were excluded from this chapter. Agricultural shenical and fertillzer production were excluded because the associated tribological sinks are discussed in the chemicals and mining chapters. The transportation of agricultural products focuses only upon material handing via conveyors and similar devices. The tribology of the tractor engines and all truck hauling are addressed in other tribology program research.

The generic tribological mechanisms contributing to energy losses in each sink are identified in Table 3.13. Tables 3.14 and 3.15 present the direct and indirect energy losses, along with additional information on the energy and material types affected by the tribological activity.

The tribological mechanisns identified in the research are indicated in Table 3.13 according to the sink 1 ) in which they are present. Three-body abrasive wear was by far the most comon activity, being significant in all sinks except irrigation. The second most commor tribological mechanism was lubricated wear, which was present in the sinks involving transportation of crops or feed and aninal waste. However, frequent occurrence of a tribological mechanism does not necessarily imply the importance of tribological energy use.

The direct and the indirect energy use (i.c.. enbodied energy in worn materials) of the tribological staks are shown in rables 3.13 and 3.14 . Indirect losses were nore than two tines greater than the direct losses. Steel erosion of tillage inplements and tractor araft requirements in tillage were the most sianificant energy sinks identified. Steel was the most common material subject to wear and also contributed the most to the indirect energy total. The material replacenent of bearings, arive belts and chains, and knife blades in combines was reported to be high these materials were consiatered to have medium wear rates. The net tribological losses, however, could not be accurately estimated by this research project because of the complexity of the problem and the resources needed to determine accurate wear rates and materlal replacenent rates. 
TARLE 3.13. Summary Table for Tribological Energy Losses in the Agricultural Industry Generic Tribological Mechanism

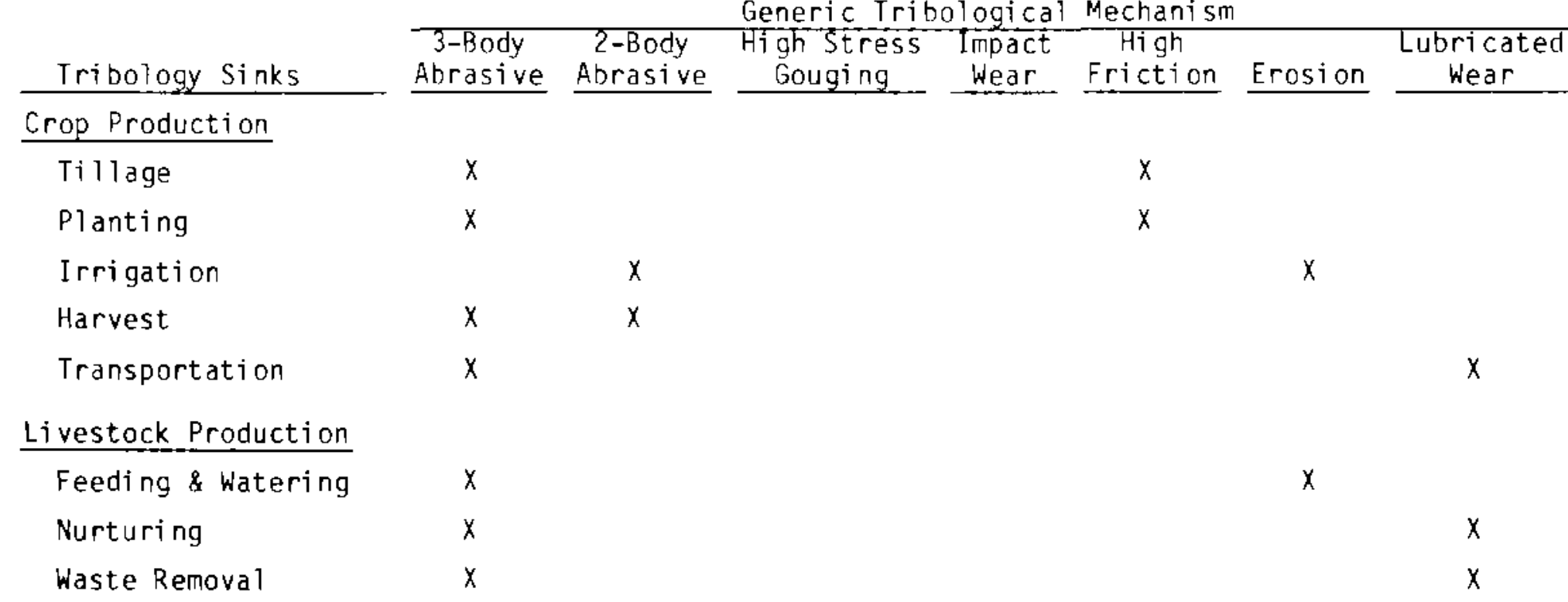


TABLE 3.14. Annual Direct Tribological Energy Losses in Agriculture

\begin{tabular}{|c|c|c|c|}
\hline Process & $\begin{array}{l}\text { Machine } \\
\text { Involved }\end{array}$ & $\begin{array}{l}\text { Site of } \\
\text { Direct Loss }\end{array}$ & $\begin{array}{r}\text { Drect } \\
\text { Loss }\left(10^{12} \text { Btu }\right) \\
\end{array}$ \\
\hline T1lage & implements $(a)$ & $\begin{array}{l}\text { Parts that } \\
\text { engage soil }\end{array}$ & 5.7 \\
\hline Planting & planters & $\begin{array}{l}\text { Parts that } \\
\text { engage sail }\end{array}$ & 1.3 \\
\hline Irrigation & Puntps & Inpeller & 1.1 \\
\hline $\begin{array}{l}\text { Transpontation } \\
\text { Total }\end{array}$ & Conveyors & Bearings & $\frac{0.029}{8.13}$ \\
\hline
\end{tabular}

(a) Implements include moldboard plow, disk plow, chisel plow, field cultivator, harrow, disk cultivator, and row cultivator.

TABLE 3.15, Annual Indirect Tribological Energy Losses in Agriculture

\begin{tabular}{|c|c|c|c|c|c|}
\hline \multirow[b]{2}{*}{ Procass } & \multirow[b]{2}{*}{ Mactizne } & \multicolumn{2}{|c|}{ Conforient } & \multirow{2}{*}{ 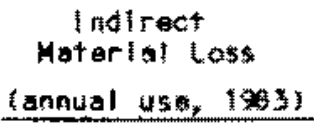 } & \multirow{2}{*}{$\begin{array}{l}\text { Equ losiant } \\
\text { Energy loss } \\
\left(10^{12} \text { atul }\right.\end{array}$} \\
\hline & & Nane & Matartai & & \\
\hline Tillags & $\begin{array}{l}\text { Imp laments } \\
\text { Iractor }\end{array}$ & $\begin{array}{l}\text { Iosl polnts } \\
\text { Ifres } \\
\text { tubertcant }\end{array}$ & $\begin{array}{l}\text { Fteal } \\
\text { Rubler } \\
\text { Petrol atum }\end{array}$ & $\begin{array}{l}4.5 \times 10^{3} 1 \mathrm{~b} \\
* \% \times 10^{7} 15 \\
2 * 7 \times 10^{\circ} \mathrm{gal}\end{array}$ & $\begin{array}{l}9.91 \\
3.05 \\
3.89\end{array}$ \\
\hline $\begin{array}{c}\text { Plantling } \\
\text { Total }\end{array}$ & Planters & In) polnts & Stent & $1.1 \times 10^{8} 10$ & $\frac{2.42}{|0.2|}$ \\
\hline
\end{tabular}

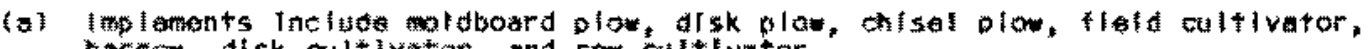

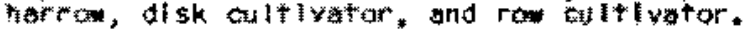

The direct enery losses were most significant in the draft requirements necessary for soil thlige. Planting and irrigation were the next most important; conveyance of crop and livestock material (excludino highway travel) was the least significant of the identified sinks. 


\subsection{REFERENCES}

Bowers, W. 1975. Machinery Management. John Deere Service Publications, Moline, llinois.

Bowers, W. and 0. R. Hunt. 1975. "Application of Mathendtat Formulas to Repair Cost Data." Transactions of the ASAE. pp. 806-809.

Clark, S. J. and W. H. Johnson. 1975. "Energy-Cost Budgets for Grain Sorghum Tll age 5ystems." Transactions of the ASAE. pp. 1057-1060.

Conveyor Equipment Manufacturers Association. 1977. Belt Conveyors for Bulk Materials. Conveyor Equipment Manufacturers Association, CBI Publishing Co, Inc., Massachusetts.

Cupin, C. 1976. Farrm Machinery. Ninth Edition, Granada Publishing, Limited.

Falrbankt, G. E* 6. H. Larson and 6. H. Chung. 1971. "Cost of using Farm llachinery." Transactions of the ASAE. p. 9 .

Hendrick, d. $\sigma_{*}$ 1980. "A Powered Rotary Chisel." Transactions of the ASAE. $23(6): 349-1352$.

Holn, R. Jr., ed. 1975. "Agricultural Machinery Managenent Data." In Agricultural Engineers Yearbook. Z2nd Edition. American Sotiety of Agricultural Engineers, warren, Pennsytuania.

Hunt, 0. Undated. "Ejght Years of farm Machinery Cost Monitoring." ASAE Paper Ao. 74-1544. American Society of Agricultural Engineers, Warren, Pennsylvania.

Implement and Tractor Red Book. March 31, 1983. Intertet publishing Corporatron.

Industrial Energy lse Data Book. 197.

Kepner. R. A. Undated. Principles of Farm Machinery. Avl Publishing Company, Westport, Connectlcut.

Lockeretz, $W_{*}$ ed, 197. Agriculture and Energy, Acadenic Press, Inc., New York, New York.

Phillips, S. H. and H. M. Young, Jr. 1977. No-Tillage Farming Raimon Assom ciates, Milwauke, Wisconsin.

Richarason, R., M. Jones, and D. Atwood, 1967. "A Pilot Survey of the Durability of Fam Machinery." Paper presented at Agricultural Symposium at the National college of Agricultural Engineering, silsoe, Bedford, England. 
Schafer, R. L. et al. 19\%9, "Experientes whth Lubricated Plows." Transactots of the A5AE. 22(1):7-12.

Shipper, 1. M. et a1. 1980. Basic Farn Machunery. Third Edition, Pergamon Press, Elmsford, New York.

Smith, S. S. and J. D. 01iver. 1975. "Farm Machinery Performance and Costs." Publication 510, Virginia Polytechnic Institute and State University.

U.5. Department of Agriculture. 1980. Agricullural Statistics. U.5. Department of Agriculture, Washington, D.C.

U.S. Department of Agriculture. 1983. Agriculural Statistics. U.5. Department of Agriculture, washington, D.C.

Wismer, R. D, et al. 1968. "Energy Application in Tillage and Earthmoving." SAE Paper No. 680611, Soclety of Agriculture lingineers, Warren. Pennsylvania. 


\subsection{PRIMARY METALS - THE IRON AND STEEL INDUSTRY}

Industries that comprise the Primary hetals category (SIC 33) are involved in processing toth ferrous and nonferrous materials.

\subsection{GENERAL INDUSTRY DESCRIPTION}

Materials processed by the primary netals industries include iron and steel, aluminum, copper, zinc, and lead. These industrias are listed by their 4-digit \$C classification in Table 4.1. Table 4.1 also shows the amount af fuel and electricity purchased in each of these SIC categories in 1980. Eesides this purchased energy, many of these metal industries produce a sigfafficant quantity of fuel internally as the by mroduct of their processing. Therefore, the total energy use is larger than that shown in the table. In an analysis of the industry in 1972 , Battelle estinated that the cotal energy consumed exceeded the purchased energy in prinary metals by $80 \%$ lBattelle 1975). This estimate is consistent with Dof data that show total energy consumption in the prinary metals industry to be $\sim 3.8$ quad.

of the industries that compose primary metals, the iron and steel industry is by far the largest energy consumer. In 1980 the iron and steel industry cansumed ?.52 quad of energy [American Iron and Steel Institute (A1\$1) 1982]. which represents 60 of the energy used in prinary metals. The second largest anergy consumer was the aluminum industry, which accounted for 20.72 quad aISI 1982). Bucause of the dominant energy consumption evidenced in the iron and steel industry aniz the similarity of processes across the primary metals industries, the analysis in this thapter will focus on iron and steel.

Although the iron and steel industry is still a major employer in the 0.5 . aconony, employment and production in that industry has decreased significantly since the late 19705. In early 1980 iron and steel industry employment was ilightly above 500,000, and the production of iron and steel products exceeded (10,000 million tons per year. In 1982, employment was down to 289, poo and product stipments were down to 61,567 million ton. This decline can be attribed to rany factors, including the effects of a national recession, increas. rg competition from foreign industries, and the aged, less efficlent condition 
TABLE 4.1. Purchased Fuels and Electricity in Primary Metals Industries [Annual Survey of Manufactures (ASM) 1981]

\begin{tabular}{|c|c|c|}
\hline SIC Code & Industry Group and industry & $\begin{array}{l}\text { and Electricity } \\
\text { (trilison Btu })\end{array}$ \\
\hline 33 & Primary Metals Industries & $2,276.8$ \\
\hline $\begin{array}{r}331 \\
3312 \\
3313 \\
3315 \\
3316 \\
3317\end{array}$ & $\begin{array}{l}\text { Blast Furnace, Basic Steel } \\
\text { Blast Furnaces and Steel Mills } \\
\text { Electrometallurgical Product: } \\
\text { Stee Wire and Related Products } \\
\text { Cold Finishing of Steel Shapas } \\
\text { Steel Pipe and Tubes }\end{array}$ & $\begin{array}{r}1,381.5 \\
1.282 .1 \\
51.0 \\
12.5 \\
14.6 \\
21.0\end{array}$ \\
\hline $\begin{array}{r}332 \\
3321 \\
3322 \\
3324 \\
3325\end{array}$ & $\begin{array}{l}\text { Iron and Steel Foundries } \\
\text { Gray Iron Foundries } \\
\text { halleable Iron Foundries } \\
\text { Steel Investment Foundries } \\
\text { Steel Foundries, NEC }\end{array}$ & $\begin{array}{r}159.7 \\
111.0 \\
10.8 \\
4.0 \\
33.9\end{array}$ \\
\hline $\begin{array}{r}333 \\
3331 \\
3332 \\
3333 \\
3334 \\
3339\end{array}$ & $\begin{array}{l}\text { Primary Nonferrous Metals } \\
\text { Primary Copper } \\
\text { Primary Lead } \\
\text { Primary 2inc } \\
\text { Primary Aluminum } \\
\text { Primary Nonferrous Metals, AEC }\end{array}$ & $\begin{array}{r}473.9 \\
53.0 \\
12.1 \\
16.2 \\
359.8 \\
32.8\end{array}$ \\
\hline 3341 & Secondary Nonferrous : Metals & 39.3 \\
\hline $\begin{array}{l}335 \\
3351 \\
3353 \\
3354 \\
3355 \\
3356 \\
3357\end{array}$ & $\begin{array}{l}\text { Nonferrous Rolling and Drawing } \\
\text { Copper Rolling and Drawing } \\
\text { Alumi num Sheet, plate, and Fetl } \\
\text { Aluminum Extruded Products } \\
\text { Aluminum Rolling, Orawing, NEC } \\
\text { Nonferrous Rolling, Drawing, NEC } \\
\text { Nonferrous Wiredrawing, Insulating }\end{array}$ & $\begin{array}{r}158.0 \\
22.9 \\
68.2 \\
19.9 \\
7.4 \\
16.0 \\
23.5\end{array}$ \\
\hline $\begin{array}{r}336 \\
3361 \\
3362 \\
3369\end{array}$ & $\begin{array}{l}\text { Nonferrous Foundries } \\
\text { Aluminum Foundries } \\
\text { Brass, Bronze, Copper Foundries } \\
\text { Nonferrous Foundries, NEC }\end{array}$ & $\begin{array}{r}39.4 \\
27.8 \\
5.3 \\
6.3\end{array}$ \\
\hline $\begin{array}{r}339 \\
3398 \\
3399\end{array}$ & $\begin{array}{l}\text { Miscellaneous Primary Metal Products } \\
\text { Metal Heat Treating } \\
\text { Primary Metal Products, Nec }\end{array}$ & $\begin{array}{r}24.9 \\
17.0 \\
7.8\end{array}$ \\
\hline
\end{tabular}


of U.S. equipment when compared with foreign plants. Historically, the industry has followed the national business cycle because a large portion of the products are used for highly cyclical construction and consumer durables. Reduced shipments to the construction and auto industries between 1973 and 1980 accounted for nearly $60 \%$ of the 27.6 million ton decline in 0.5 . steel shipments [0fflee of Technology Assessment (10TA 1980)]. Because of the recession's significant impact on this industry, 19 sz was not consldered to be good "typleal" year for the analysis. Although an analysis of the future markets tor the industry is well beyond the scope of this study, estimates by OTA (1980) and the AISI (1982) predict production to he relatively stable over the decade at output approximately equal to that in 1980 . Therefore, the analy sis in this chapter will be conducted with 1980 statistics.

In 1980 the iron and steel industry employed 399,000 workers and shipped 8.3,853,000 tons of products. These products are shipped in various forms, including structurals, plates, bars, pipes and tubes, wire, tin mill products, and sheets. The percentage distribution of these products and their projected values if 1985 and 1990 are shown in Table 4.2. In 1990, $87.5 \%$ of the shipm ments were carbon steel products, $1.3 \%$ were stainless and heat resisting, and $11.2 \%$ were other alloys (0TA 1980).

Figure 4.1 is a very general schematic of the najor processes involved in producing iron and steel. These steps include preparing the coking coal and the iron ore, smelting the iron in a blast furnace, produchng steel in a steelmaking furnace, casting the steel into ingots or creating stock through a continuous process, and rolling and forming the steel into the deslred products. These processes are further detalled in Table 4.3.

0verall energy use in the iron and steel industry has been declining in the late 1970 s and early 1980 s because decreased production and increased use of energy conservation measures. Overall energy use by fuel type from $197 \mathrm{a}$ to 1982 as compiled by the Alsi is shown in Table 4.4.

The distribution of energy use in the major energy-consuming processes is shown in Figure 4.2. The figure clearly shows that a large amount of energy is consumed in the thermally intensive processes. The blast furnace alone 
IABLE 4.2. Projection of Product Mix in U.S. Steel

Production, 1976-2000 (0TA 1980, p. 141)

\begin{tabular}{|c|c|c|c|c|}
\hline \multirow[b]{2}{*}{ Product. } & \multicolumn{4}{|c|}{ Nistribution of Product Mix $(\alpha)$} \\
\hline & $1976^{(a)}$ & 1980 & 1985 & 1990 \\
\hline Structural & 10 & 12 & 12 & 12 \\
\hline Plate & 9 & 10 & 10 & 10 \\
\hline Rails & 2 & 2 & 2 & 2 \\
\hline Hot-rolled bars & 9 & 7 & 7 & 7 \\
\hline Other bars & 7 & 9 & 9 & 9 \\
\hline Pipes and tubes & 9 & $\$ 1$ & 13 & 15 \\
\hline wire & 3 & $z$ & 2 & 2 \\
\hline Tin mill products & $?$ & 7 & 6 & 6 \\
\hline Hot-rolled sheet and strip & 17 & 15 & 15 & 14 \\
\hline Cold-rolled sheet and strip & 20 & 17 & 16 & 15 \\
\hline Galvantzed sheat & 7 & $g$ & 8 & 8 \\
\hline
\end{tabular}

(a) Average of $1975-77$ used to eliminate fluctuations,

consumes $40 \%$ of the energy used in the industry, followed by heating and annealing, which consumes 15\%; steelmaking, which consumes 10\%; and coking, which consumes 10 .

One of the difficulties in tracking the energy use in this industry is that a large portion of the energy consuned is certerated internally. Figure 4.3 shows the distribution of the different forms of energy as well as the recycling of the by-product gases. This figure aydin shows the dominant energy use of the thermally intensive processes.

The tribological energy sinks are not, however, marked by these themally intensive processes but by mechanical processes. The most significant mechantcal processes occur during the initial stages of ore preparation (e.g., pelletizing) and in the secondary or finishing processes (e.g., rolling and milling). Figure 4.1 al so shows the materials flows through these processes and traces the processes to the products that are produced. Both the thermal and mechanical processes will be described in more detail in the next section. 


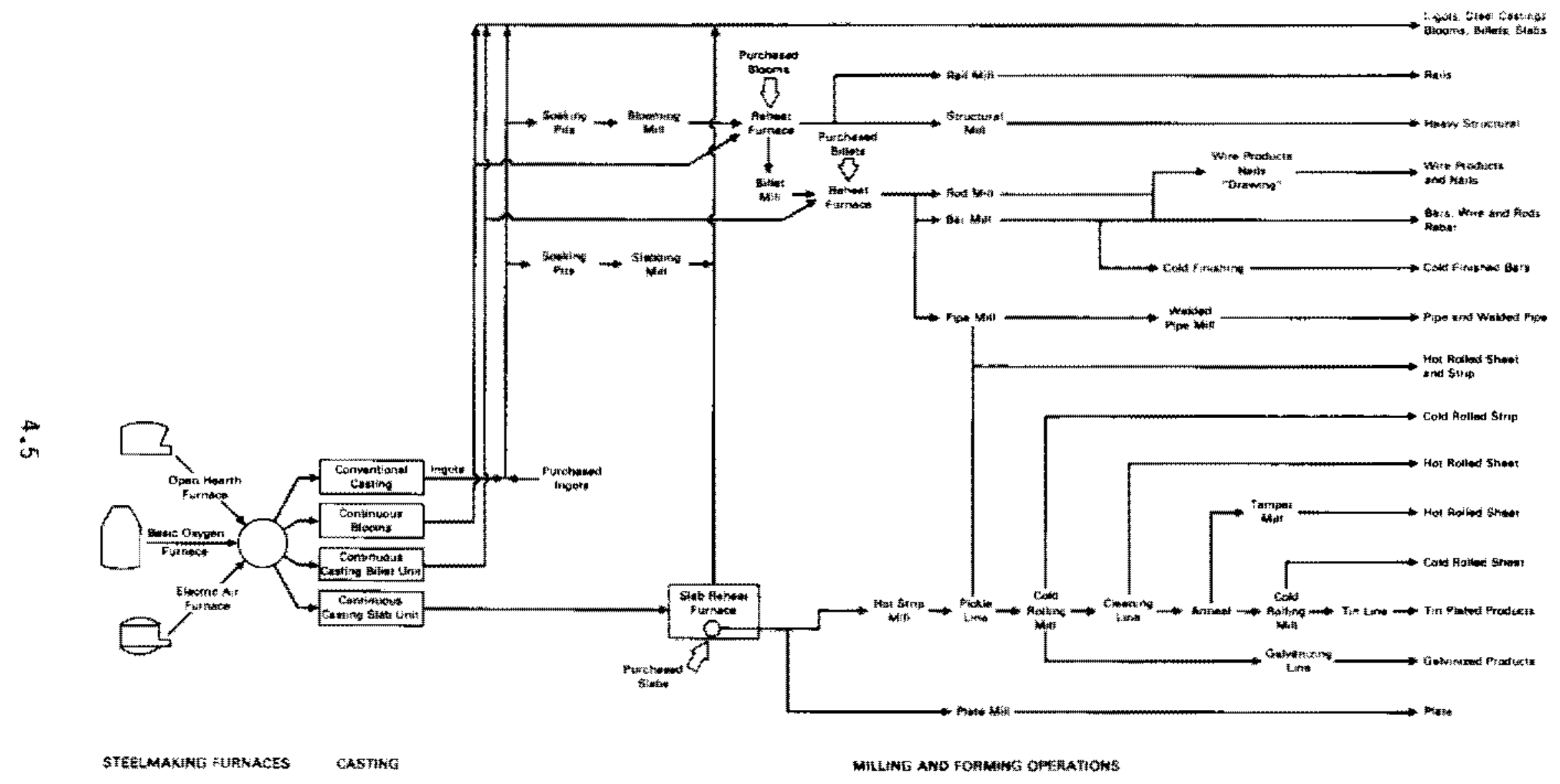

FIGURE 4.1. Major Processes Involved in Producing Iron and Stee? 
TABLE 4.3. Energy Servicet and Major Processes in the Iron and steel industry (0TA 1980)

Energy Service

Beneficiation

Coming

Ironmaking

Steelmaking

Primary finishing

Heat treating
Major Processes

sintering

pelletizing

By-product cake oven wet quench

By-product coke oven/dry quench

Formcoking

Elast furnace

Blast furnace with hydrogen injection

bi rect reduction--gas

Direct reduction-woal

Basic oxygen fumace

Electric are furnace

open hearth furrace

Ingot casting/soaking/breakdown will

Continuous casting

Ladle preheatirg

Secondary finishing Batch reheatinc/rolling

continuous reheating/rolling

Electric induction reheating/rolling

Direct rolling

cold rolling

Direct tules furnace

Radiant tube fumace

Electric furnace 
TABLE 4.4. Fuel Use and Energy-Related Trends in the Steel Industry (AISI 1982)

Fuel lse per Ton of

\begin{tabular}{|c|c|c|c|c|c|c|}
\hline Steel shipnents $\left(10^{8} \text { Btu }\right)^{(a)}$ & 1976 & 1977 & 1978 & 1979 & 1980 & 1981 \\
\hline coal, coke & 22.4 & 20.0 & 17.2 & 17.9 & 18.2 & 16.0 \\
\hline Coal, stean & 0.8 & 0.8 & 0.8 & 0.8 & 0.8 & 0.8 \\
\hline Natural gas & 6.7 & 6.2 & 6.1 & 6.4 & 6.7 & 7.0 \\
\hline Purchased coke & 1.7 & 1.2 & 1.7 & 1.9 & 1.2 & 0.8 \\
\hline Fuel oll & 2.7 & 2.8 & 2.9 & 2.1 & 1.3 & 1.1 \\
\hline Liquefied petroleman gas & 0.7 & 1.0 & 0.5 & 0.3 & 0.2 & 0.2 \\
\hline Purchased electricity (b) & 1.7 & 1.7 & 1.7 & 1.7 & 1.8 & 1.9 \\
\hline Totals, $10^{6}$ etu & 36.7 & 33.7 & 31.0 & 31.1 & 30.2 & 27.8 \\
\hline Cost, (c) 1982 dallars & 128.4 & 120.6 & 113.7 & 114.0 & 109.4 & 105.5 \\
\hline \multicolumn{7}{|l|}{ Recent Trends } \\
\hline Shipments, $10^{6}$ tons & 89.4 & 91.1 & 97.9 & 100.3 & 83.9 & 87.0 \\
\hline Raw Steel, $10^{6}$ tons & 128.0 & 125.3 & 137.0 & 136.3 & 111.8 & 119.9 \\
\hline Held, 㛃(1) & 69.8 & 72.9 & 71.5 & 73.6 & 75.0 & 72.6 \\
\hline wontinuous cast, & 10.6 & 12.5 & 15.2 & 16.9 & 20.3 & 21.2 \\
\hline \multicolumn{7}{|l|}{ of raw steel } \\
\hline Open hearth & 18.3 & 16.0 & 15.6 & 14.0 & 11.7 & 11.2 \\
\hline Bastic oxygen process & 62.5 & 61.8 & 60.9 & 61.1 & 60.4 & 61.1 \\
\hline Electeric arc furnace & 19.2 & 22.2 & 23.5 & 24.9 & 27.9 & 27.7 \\
\hline rotal purchased scrap, ofe) & 36.0 & 40.0 & 40.0 & 43.0 & 48.0 & -- \\
\hline
\end{tabular}

\footnotetext{
a) Based on representative generating heat values.

(b) Assuming 34128 tu/kwh.

(c) 1982 axerage prices applied to yearly figures.

c) Shipments divided by raw 1 iquid steel. The decline in 1981 is an artifact of a sharp increase in inventory.

c) Percent of total metallic feedstocks.
} 
Percent of Overall Energy Consumption

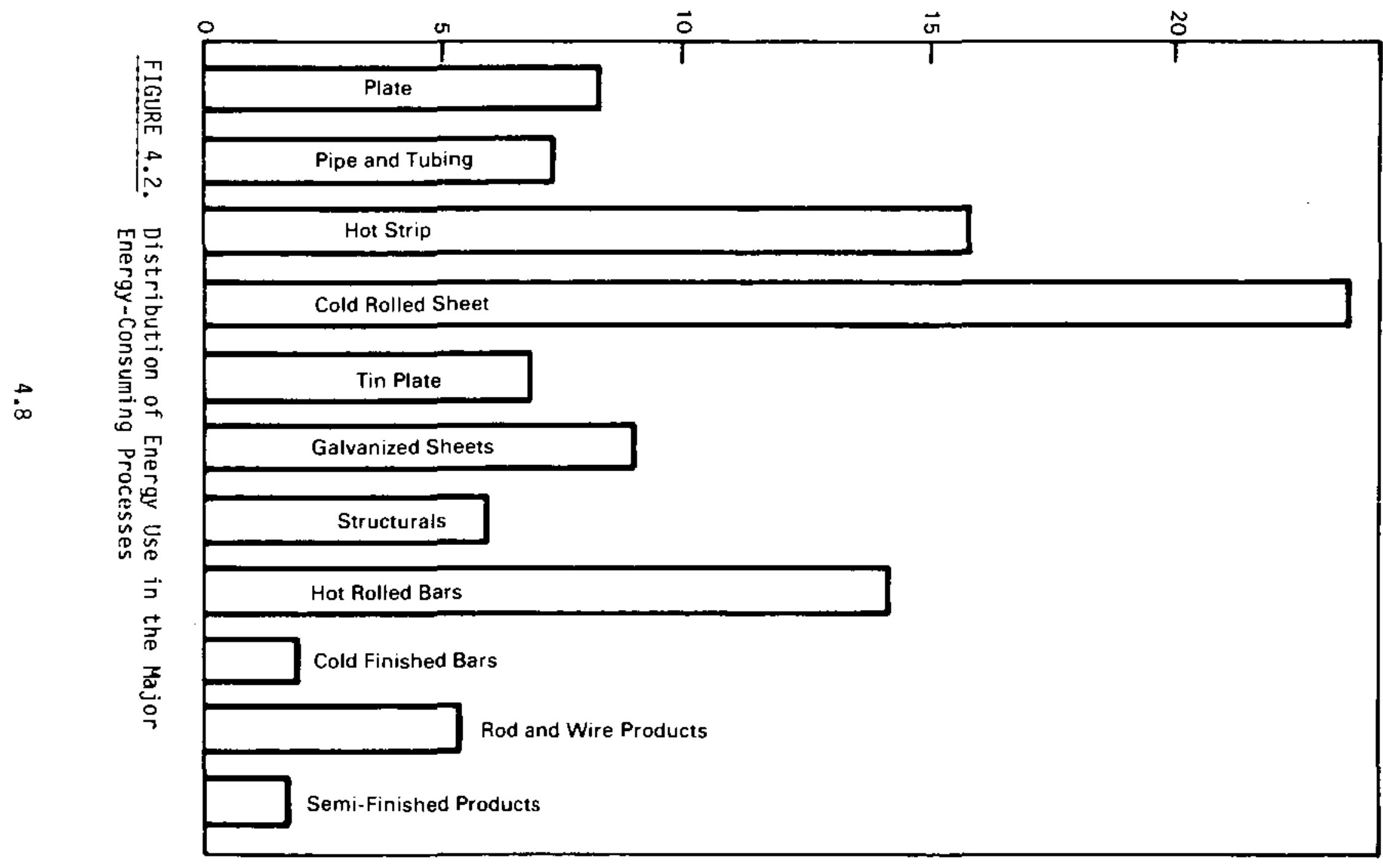




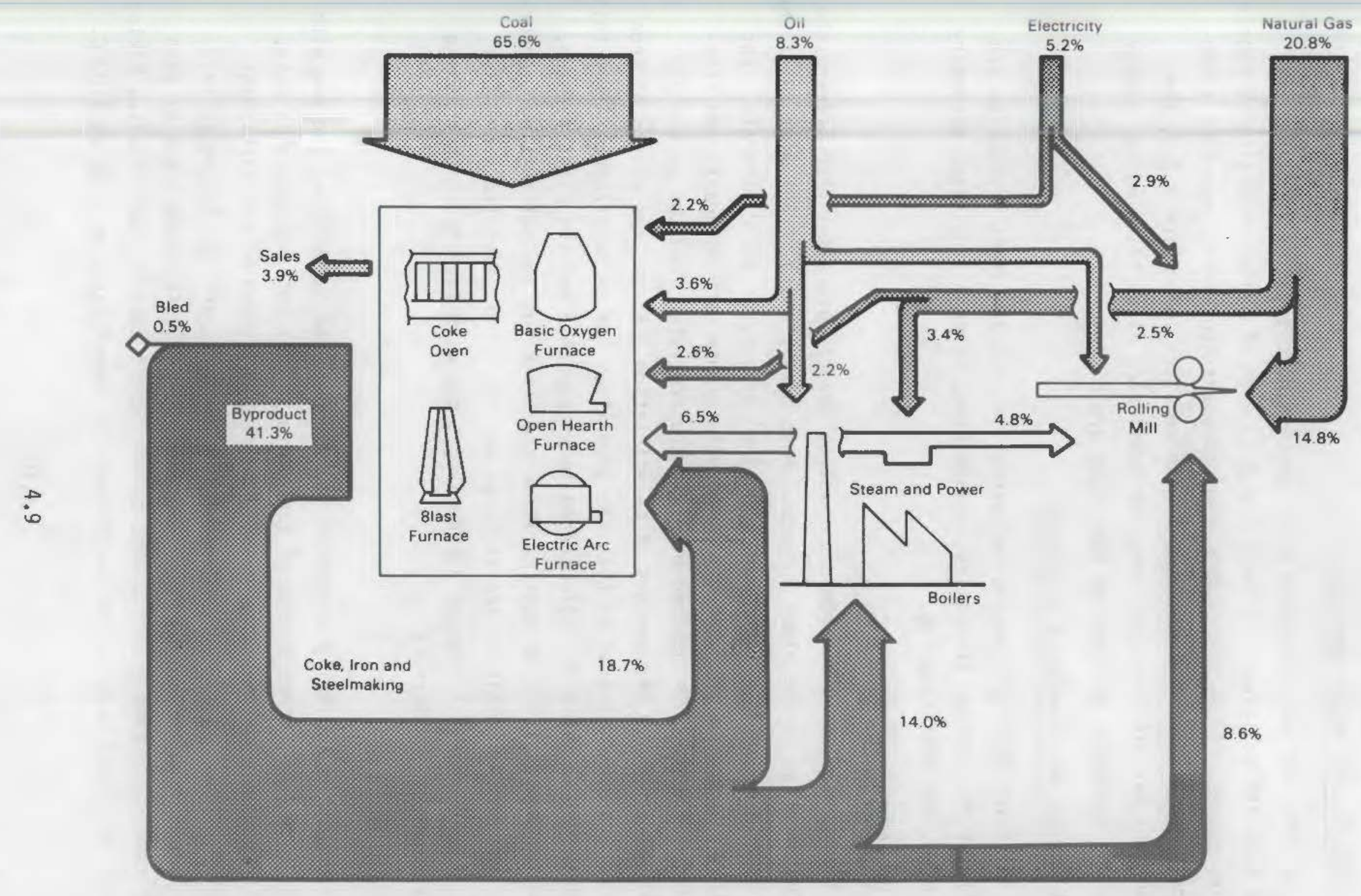

FIGURE 4.3. Distribution of the Different Forms of Energy and the Recycling of By-Product Gases 


\subsection{ANALYSIS OF MAJOR PROCESSES}

In this section, the seven major processing categories loutlined in Table 4.3) are analyzed. In Section 4.2.1, each of these processing categories are introduced. In Section 4.2.2, the processes containing important tribological energy sinks are reviewed in more detail. In Section 4.2.3, the reasons why certain processes were not considered major tribological energy sinks and therefore left out of the study are discussed.

\subsubsection{Major Iron and Steel Processes}

The seven major processing categories in iron and steel production are beneficiation, coking, ironmaking, steelmaking, primary finishing, secondary finishing, and heat treating.

\section{Beneficiation}

The beneficiation of iron ore involves several processes that prepare the ore for smelting in the blast furnace. Most metallic ores are a mixture of the desired metal-bearing minerals and undesired gangue, or waste minerals. For example, iron oxides are commonly mixed with gangue such as quartz and ironbearing silicates. The desired minerals are separated from the gangue and concentrated through the process of beneficiation. First, the chunks of iron ore are crushed and ground so that the impurities can be separated. After this refining, the iron ore is agglomerated in preparation for the blast furnace. The most common methods of agglomeration are sintering and pelletizing. Generally, the courser particles are sintered and the finer particles are pelletized. Both processes produce a burden that can withstand the high crushing forces in the blast furnace.

\section{Coking}

Iron ore is typically converted to metallic iron by reducing the ore with carbon. The most common source of the carbon in current ironmaking is coke. Coke is generally derived from metallurgical coal, which blends particular characteristics of sulfur content, volatile content, and caking properties. About 1.46 tons of metallurgical coal are consumed in the production of each ton of coke (A.D. Little 1978). The conversion of coal to coke involves baking the coal in a coke oven for 16 to 18 hours in temperatures as high as $1100^{\circ} \mathrm{C}$. 
The volatiles are driven off from the coke in gases, and the coal is transformed into hard, porous coke that is about $90 \%$ pure carbon.

Ironmaking

In the ironmaking process the coke, agglonerated iron ore, other ironbearing naterials (e.g. scrap), and flux (e.g. Iinestone and dolomite) are charged into the top of the blast furnace. Heated alr is blown in at the bottom of the furnace. This not air burns the coke as it descends to heat, reduce and melt the charge, The iron oxide is converted to liquid metallic iron and "s collected at the botton of the furnace. As mentioned earlier, this is the "argest knergy-consuming step in making iron and steel.

Steylmaking

The molten iron produced by the blast furnace, or pig iron, is then further processed to make steel. Steelmaking is a process in which undesirable anounts af other chenical elements such as carbon, manganese, phosphorus, sulfur, and silicon are reduced and removed from the pig iron. other elements such as fuxes and alloying materials are added to produce the destred steel properties IOTA 1980$)$.

Three principal types of equipment are used in steclmaking: the basic (xygen furnace (BOF), the electric arc furnace (EAF), and the open hearth furrace. The most widely used steelmaking furnace is the BOF, which produced $61 \%$ c) the notion's steel in 1979 (0TA 1980). The advantages of the eof are its fast processing rates and its ablity to produce carbon steel as well as the various alloyed steel. The steel is refined at a rate of zo minutes per batch by an intense chemical reaction produced in the charge of irons scrap, and ine.

The EAf prodtced 27\% of the nation's steel in 1980. This furnace produces steel y creating an electric arc in the scrap tharge. The advantages of this furnace are its ability to accept charges of $100 \%$ scrap the BOF is limited to about 30\%) and its econony in small-scale operations. These snall-scale operations, known as minimills and specialuty shops, are the segments of the steel industry that have not been declining as much as traditional integrated plants. These stall-scale plants have the advantages of being able to produce their 
products entirely from scrap, thereby avolding much of the cost associated with processing raw iron ore and belng able to tallor their products for specific markets. The cost advantage of scrap-based production is estimated to be $\$ 130$ per ton (32\%) less expensive than production from iron ores.

Open hearth furnaces are the oldest of the three steelmaking furnaces. Use of this furnace peaked in the 1940 s and 1950 s and has been declining stead1y since the faster BoF came into use in the 1960s. In 1980, the open hearth furnace furnished 12 of the domestic steel protuction.

Primary Finishing

The primary finishing step involves casting the molten steel and preparing the steel into rough, semifinished shapes. The two methods most comonly used are ingot casting and continuous casting. The conventional route involves ingot casting, in which the liquid steel is carvied by a refractory lined contalner, known as a ladle, to a series of molds and poured to form ingots. After the ingots cool, they are stripped and platced in "soaking ofts" where they are reheated in preparation for rolling. the reheated ingots forms are then rolled into blooms (rectangular forms), billets (square forms) and slabs.

A more recent alternative primary finishing tachnique involves cont inuous casting. In continuous casting the liquid steel is formed directly into the semifintshed forms. By avolding the intermediate casting and reheating steps, the continuous casting technique is more energymefficient than the conventional process and has a higher product yield. Energy consumption can be reduced by one-half, while product yields can be increased from $82 \%$ with the conventional method to $96 \%$ with continuous casting.

Secondary finishing

Secondary finishing involves converting the semifinished forms that are produced in primary finishing into the eventual steel products. In secondary finishing the slabs, blooms, and billets are reheated and processed through hot and cold rolling into the plates, bars, pipes, and sheets that are the final products. The most significant mechanical enersy losses occur in these rolling operations. Much of the analysis of tribological energy sinks will center around these processes. 


\section{Heat Treating}

Heat treating is frequently the find step in the finishing operations, The principal purposes of heat treating are to relieve stresses that develop in the stee during processing, to obtain full recrystallization to a more uniform grain structure, and to improve ductility to a level suitable for forming operations (OTA 1980). Conmon methods of heat treating include annealing, nornatiz"ng, spheroidizing, hardening, tempering, carburizing, and stress rellevind.

\section{2.? Processes Containirg Significant Tribological Sinks}

Because friction, wear, and lubrication are associated with motion, the nost likely areas for improving tribological energy use are those involving driven machinery. Therefore, the following discussions focus primarily on processes involving mechanical motion.

The most significant areas for tribological energy losses in the manufacture of firimary metals are milling and the hot and cold rolling processes. Ore milling is discussed as a subtopic of the Mining Industry in Chapter 2.0. Hot roling and cold rolling, which are used to produce $90 \%$ of U.S. Steel products (Darby and Arons 1979), are discussed below.

\section{Hot Rolling}

Hot rolling is the predominant technique used in the mechanical processing of iron and steel. Several different types of hot rolling mills are used in processirg different steel products. These mills generally fall into two categories: frimary mills and finishing mills. Primary mills are used in the initial roling of the steel ingots or the continuously cast forms. These mills include slab, bloom, billet and plate mills. In some cases, products are shipfed directly after these primary hot rolling steps. In other cases, steel is further frocessed in secondary hot mills, which include pipe, rod, rail and bar mills. The relationships among the various hot rolling mills is shown in Figure 4,1. The electrical energy consumption and the material yields of the major types of hot rolling mills are shown in Table 4.5. Because of the prevalence of hot rolling, it is the primary candidate for energy savings through tribological improvenents. 
TABLE 4.5. Typlcal Yelds and Electrical Energy Consumption of hot Rolling processes

\begin{tabular}{lcc} 
Mill Operation & Yield (q) & $\begin{array}{r}\text { Electrical Energy } \\
\text { Consumption (million } \\
\text { Btuperton) }\end{array}$ \\
\hline Slabbing/blooming mill & 85 & 0.32 \\
Platemilt & 80 & 0.95 \\
Hot strip mill & 96 & 1.05 \\
Temper mill & 97 & 0.35 \\
Billet mill & 97 & 0.47 \\
Rodmill & 93 & 0.82 \\
Bar mill (hot roll) & 93 & 0.53 \\
Bar mill (cold finish) & 96 & 0.21 \\
Structural mill & 96 & 0.44 \\
Pipe mill & 90 & 0.89
\end{tabular}

The practice of hot rolling varies widely from plant to plant and its energy requirements depend on many factors, including total reduction, reduction per pass, rolling speed, yield, thermal treatments, downtime and mill size. Energy requirenents also vary measurably with the equipnent scheduling. Maximum efficiency is achieved with continuous, around-the-clock operation. Reducing this schedule to a six-day week increases energy use by $10 \mathrm{t}$, and reducing the schedule to two shifts per day (14 hours per day) increases energy losses by another $5 \%$ to $10 \%$.

Within an integrated steel plant, hot rolling accounts for the major portions of electricity, maintenance, and lubricant consumption. Processes associated with hot rolling account for over $50 \%$ of the electricity used in integrated steel plants. Approximately 65 is used in reheating and 350 goes to powering the nills. In 1900, about 30 to 35 trillion Btu of electricity were used fre driving hot rolling mlls. Hot rolling also accounts for $66 \%$ of the maintenance costs and $89 \%$ of the plant's lubricant consumption. 
Hot rolling is performed at a high temperatire so that the netal is soft and susceptible to large deformations. At this high temperature the metal can "recrystallize" after it is deformed to maintain its original (before rolling) biroperties.

The main causes of roll wear in hot rolling operations are abrasive wear ty oxides formed on the roll and work piece surfaces, and thermal cycling of the roll surface. Tribological improvenents are most likely to affect the abpasive wear aspect of roll performance. The severity of the abrasive condition depends upon the hardness of the oxides forned in the rolling process. cxide hardness varles with axide compostion, which depends on the cemperature at whith the oxides are formed. For example, wstite (Feo) forms at under $1550^{\circ} \mathrm{F}$ and is soft (HV(a) $\left.270-350\right)$. At temperatures above $1650^{\circ} \mathrm{F}$, magnetite $\left(\mathrm{Fe}_{3} \mathrm{O}_{4}\right)$ and hamatite $\left(\mathrm{Fe}_{2} \mathrm{O}_{3}\right)$ begin to dominate with hardness of $\mathrm{HV} 420 \mathrm{~m} 500$ and HW 103h, respectively. Roll wear can be reduced by minimizing the formation of the harder oxides, magnetite and haematite. This formation can be mininized by keeping the roll temperature below $1650^{\circ} \mathrm{F}$.

Hot roll lubrication is helpful for mininizing roll temperature in two was. First, the oil/water mixture cools the rolls directly. Second, the inproved aerformance of lubricated hot rolling mills enables mill operators to apply ies preheat furnace and reduces roll wear.

The direct and indirect energy losses in hot rolling are discusced sepam ately below, followed by a sumary of the major findings in the analysis of hot rolling.

Direst Energy Losses in Hot Rolling. The mechanical deformation of iron and steel that octurs by hot rolling has significant friction and wear problens involving both the roller and the material being rolled. Before the advent of igh-temperature lubrication in hot rolling devices, the typical efficiency of the process ranged from $60 \%$ to 70 . Lifetimes for hot rolls vary significantly th size and service, but a roll often needs to be replaced several times a sear.

c) Hy is the Vickers hardness number, which is a microhardness technique emplcying a diamond pyramid indenter. 
Duming the past several years, hot rolling efficiency has improved significanty because of the experimental application of liquid lubrication in the 1.5. (Cichelli and Poplawski 1980), England (will ans 1980), and Japan (Suzuki and Jeda 1976). Energy consumption could be refuced through one of three different approaches:

- Reduce direct energy consunption in the mill drive motor while keeping all other mill operating parameters constant. Using liquid lubricant in this capacity has reduced energy consumption 15 to $25 \%$ according to various European, Japanese, and American mill operators (w) 11 ans 1980$)$.

- Increase the amount of reduction taken during each pass, thereby reducing the number of passes needed to produce a fixed amount of product. This is another way of saving mill-drivemotor power as well as increasing mill capacity.)

- Reduce the amount of preheat energy required in the soaking pits since the metal does not have to be as soft when hot rolled with a lubricant.

The third appraach nay prove to save the most energy since, in addition to reducing soaking pit energy consumption, lower colling temperatures offer addithonal advantages. These advantages include less scale formation lscale is abrasive to the work rolls and is also costly to machine away), less lubricant boil-off, and less roll cooling requirements.

In the U.S. steel industry, an estimated 12 trillion Btu of energy were consumed by friction in the hot rolling operations of integrated plants. Consequently, if $8 \%$ were recovered with hot roll lubrication by the first approach above, the industry colld save about 1 trlllion Bty per year. If the third approach were adopted, about 8 trillion Btu could be saved annually by reduced metal loss due to scale removal. Additional savings of 11 trillion Btu would be reallzed through reduced soaking pit energy consumption (Cichellt and poplawsk 1980). These energy galns would be offset only partially by a lubricant consumption of only about 40 cubtc centimeter per ton of steel rolled. 
Indirect Energy Losses in Hot Rolllng. In addition to the direct energy losses cited above, significant energy losses result from material wear and from the lubrication used. As a result of the abraston and themal fatigue cracks incurred during rolling, the rollers need to be reground frequently. Hat rolis are reground about once per shift with 0.020 to $0.030 \mathrm{in}$. of the roller removed. Hot rolis are typically replaced when about low of their diameter is lost by grinding. In this analysis approximately 0.1 lb of roll matem $r$ al is lost for every ton of steel processed. (a) About half of the embodied material loss is cue to wear and half is due to themal fatigue cracking. Approximately 210,000 tons of rolls are replaced each year, with an embodied energy content of 6.3 trillion Btu.

Hor, wolling lubrication can reduce indirect energy consumption in two ways:

- reduced roll wear, which results in less frequent roll reconditioning and replacement

- better product surface quality, which enables mills to produce nore prentum-grade product without additional process steps.

Willatus (1980) reported that in Japan and the 1.5. roll life has increased $20 \%$ to $40 \%$ when hot-roll lubrication has been used.

Sumary of Major Findings for Hot Rolling. Hot rolling mills compose major element of the tribological energy losses that occur in the iron and steel industry. Although there are a variety of hot rolling mills, the major tribological losses are common. The average efficiency of conventional hot. rolling processes is $60 \%$ to $70 \%$, with an overall energy use of 30 to 35 trillion Bti. However, recent advances in high-temperature lubrication technology have increased this efficiency by approxinately 8\%. Tribological factors also contribute to about half of the material degradation of the rolls. This results in material loss of 210,000 tons of steel, with an embodied energy content of 6.3 trillion Btu.

(a) Based on a reversing mill with rolls 24 inches in diameter and 56 inches wide. 
The technologies associated with hot rolling lubrication are currently quite young. Among the possible issues considered for additional optimization are the following:

- base lubricant selection (currently ester-based synthetics are favored for their higher temperature capabilities) and viscosity optimization

- lubricant additive formulations fcurrently extreme pressure and emulsifiers are used)

- delivery method (inwolyes selecting the best location for applying the lubricant and the proper mixture of oil and water.

Cold Rolling.

Cold rolling is a secondary finishing step that further refines the quality of the hot rolled forms into the shipped products. In general, any steel product that is to be thinner than $\sim 0.049 \mathrm{in} .(\mathrm{C} .125 \mathrm{~cm})$ must be rolled further in a cold rolling mill.

Cold working is performed at a temperature that will soften the metal somewhat, but below the temperature that will "recrystallize" the metal. As such, cold working deformations increase the hardness of the metal by altering the shape of the grains of which it consists. Consequently, intermittent annealing is often required after certaln amount of cold working to enable it to be deforned further. Cold rolling operations generally involve smaller. deformations than hot rolling operations. Surface finish quality and dimensional control are generally more important in cold rolled products than in hot rolled products.

Although cold rolling is used in producing far fewer products than hot rolling. its energy intensity is greater because the material is less malleable. Approximately 25 billion Btu of electricity were used in cold rolling operations in 1980.

The direct and indirect energy losses in cold rolling are discussed separately below. 
Direct Energy Losses in Cold Rolling. Although cold rolling is mare energy-futensive than hot rolling, the mechanical efficiency of the process is comparatively higher because of the widespread use of lubricants. Estimates of mechanical energy efficiency in cold rolling range from $60 \%$ to $90 \%$. This translates to an energy sink of about 2.5 to 10 billion Btu of electricity annually.

Indirect Energy Losses in Cold Rolling. Because of the strict finishing requirements of cold rolled products, less wear is tolerated on cold rolling equipment than on hot rolling equipment. Cold rollers are typically reground two or three times per eight whour shift with $0.003 \mathrm{in}$. to $0.005 \mathrm{in}$. renoved from the diameter of the cold roll with each regrind. The principal concern in regrinding the roller surface is the high surface quality desired for cold rolling products. Generally, these rolls are replaced when $10 x$ of their diameter as been lost. In this analysis, approximately $0.21 \mathrm{~b}$ of roll were assumed to be lost with each ton of steel processed. (a) Because less material is ground away when compared wh the hot rolling rollers, cold rollers last three to five times ionger. Approximately 4200 tons of cold rollers are replaced each year, representing an embodied energy content of 0.14 trillion Btu.

\subsubsection{Pracesses Not Containing Significant Tribological Losses}

In this section, the processes not containing important tribological iasses and excluded from the study are discussed.

Primary Iron and Steelmaking Processes - As described earlier, the primary energy-consuming processes in ironmaking and steelmaking are the thermal processes. The largest thermal processes occur in the initial stages of material brocessing in the coke ovens, blast furnaces, and steelmaking furnaces. 47 though these processes represent a very large percentage of the energy consumed in this industry, they are almost entirely thermal, and little potential for energy savings from tribological improvenents was nated. As a result, the jrimary processing steps were excluded from further analysis.

a) Based on a 5 -stand mill with 10 work rolls. 
Ore Grinding - This is a necessary process step in producing aluminum. Consequently, the principles discussed in the mining chapter (chapter 2.0) apply to aluminum nanufacture. However, only about 2 trillion bty are consuned annually in grinding aluminum. Similarly, because aluminum products are rolled, some direct energy losses discussed in steel hot rolling are applicable. However, due to its lower hot-hardness, bluminum requitres much less energy to roll than is required by steel.

Sintering and Pelletizing - After most of the gangue has been separated from iron ore, the ore is agglomerated into gramular lumps by sintering or peljetizing. Sintering is accomplished by heating the powdered ore from $2400^{\circ} \mathrm{F}$ to $2700^{\circ} \mathrm{F}$ to bond the particles. Pelletizing is a similar method that incorporates a small amount or bonding agent before tha powder is rolled into pellets while being heated to about $2400^{\circ} \mathrm{F}$. Fuel requirements for sintering and pelletizing are 1.6 million Btu per ton and 0.6 million Btu per ton, respectively. However, almost all of this energy is thermal input and therefore does not. involve a significant amount of tribology. Although some chronic wear problems have been reported, they do not appear to nerit in-depth study.

Bearings - Bearings for the rolling mills typlcally weigh 100 it to 2001 b and are kept in service from anywhere between 7 months and 20 years. Because the amount of material loss in bearing replacement is small compared to the roll materlal replaced, bearings were not examired further.

Aluminum Production - Refining aluminum reculpos more energy per ton than the other common metals (iron, copper) (chioglogi 1979). However, the vast majority of this power is consumed in digesting bauxite in caustic soda under heat and pressure, which initiate the production of alumina. By comparison, the tribological problems involved with aluminum processing are less serious than those of iron and copper. This is partially because almost all bauxite consumed in the U.S. is imported and therefore finingmrelated tribology energy sinks are deferred to other countries. A further mining consideration is that bauxite is usually found near the surface and therefore requires little overburden hand ing. 


\subsection{SUMMARY}

Although the iron and steel industry is one of the largest energym consuming industries in the economy, most of this energy is directed toward the themal processing of materials. Tribological energy losses are, however, important in the secondary or finishing operations, in which the iron and steel is mechanically deformed into the shipped products. The principal categories of metalworking operations with tribological energy losses are hot rolling and cold rolling. The direct and indirect energy losses are sumarized in Table 4.f, and the mechanisms of tribological loss are summarized in Table 4.7 .

Hot rolling is the most widely used methot of forming the steel products into various product shapes. This category comprises a wide variety of mills including slabbing, blooming, plate, hot strip, bar, and pipe mills. The principal conponent of tribological inefficiency in these mills is the abrasive wear caused by the oxide scales that form on the roll and work pieces. An estimated 12 trillion ptu of energy are lost due to friction and 14.3 zrlllion Btu are lost indirectly due to wear-related replacement of the work rolls and removal of scajes that form on the work piece.

The other principal category of metalworking is cold rolling cold rolling is used in refining the size and finish of certain steel products, and its

use is consequently much nore limited than hot rolling. It is estimated that 5 billion Btu of energy are lost to friction in cold rolling and that an additional 143 bilion stu are lost in the roll material replaced.

This preliminary andysis indicates that a sizable direct and indirect eneray losses can be attributed to tribological inefictencies in iron and steel hot rolling processes. Research relevant to these losses would address a significant energy sink and would add to the technical understanding and control of processes that would benefit other primary metals industries. 
TABLE 4.6. Direct and Indirect Energy Losses Analyzed in the Iron and Steel Industry

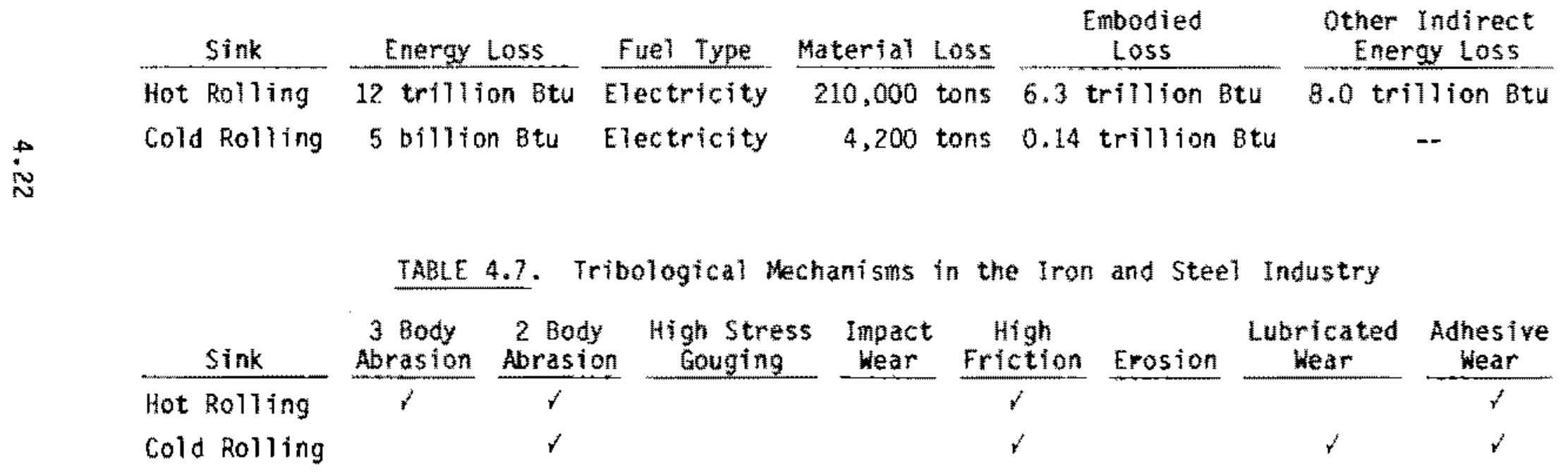




\subsection{REFERENCES}

Mmerican Iron and Steel Institute (AISI). 1982. 1982 Annal Statistical

Report. American Iron and steel Institute, Washington, D.C.

Annua? Survey of Manufactures (ASM). 1981. "Fuels and Electric Energy Used." U. S. Department of Census, Washington, 0.C.

A. 0. Lutle, Inc. 1978. Research, Development and Demonstration For Energy Conservation. SAN/1692-1, U.5. Department of Energy, Washington, 0.6 .

Battelle hemorial Institute. 1975. Potential For Energy Conservation in the Steel Industry. Battelle-Coluntus Laboratories, Columbus, ohio.

Chiogiogi, M, H, 1979. Industrial Energy Conservation. Marcel Dekker, Inc., New York, New York.

Cichelli, A. E. and 1 . V. Poplawski, 1980. "Tribology and Energy conslderations in the Rolling of Steel." Energy Technology. ASLE Special Publication

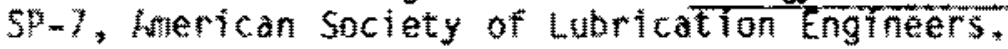

[arby, J. B. and R. M. Arons. 1979. Energy and Materials Flows in the Fabrication of Iron and steel Semifinjshed Products. ANL/CNSV-8, 0.S. Department of Energy, Washington, D.C.

Iffice of Technology Assessment. 1980. Technology and the Steel Industry Competitiveness. Office of Technology Assessment, Washington, D.C.

Suzuki, and $k$. Ueda. 195. "Characteristics of Roll With Lubrication in Hot strip and plate Rolling." Kawasaki steel Corporation, Chiba dapan.

Wlllians, K. L. 1980. "Hot Strip Mill Roll Gap Lubrication," I. Mech. E., c $143 / \varepsilon 0, p p .23-27$. 



\subsection{CHEMICAL AND PETROLEUM REF INING INDUSTRIES}

In this chapter, total energy use and tribological losses in the chemical and petroleum refining industries are identified. Energy consumption is spec: fied by major industry sectors (industrial inorganics, plastics, drugs, etc.) for various fuel types. Tribological losses in the process operations of the t.wo industries are identified, and operations having significant tribological losses are then reviewed and described in more detail. For each operation, the rlature and magnitude of the tribological losses are also estimated. This information is used to calculate the total direct tribological loss from that operatior in the whole industry. These losses are summarized in a table at the end of the chapter. Indirect losses are briefly examined, but only in a qualitative minner. Because many assumptions had to be made in developing these figures, the major causes of uncertainty are noted and discussed.

\subsection{INTFODUCTION}

According to the 1972 Standard Industrial Classification (SIC) manual, the chemical industry (SIC 28) includes establishments producing basic chemicals or manufacturing products by predominantly chemical processes. The industry has eight major 3-digit SIC subdivisions, which are listed in Table 5.1. Many of these sutdivisions use combinations of similar process steps, commonly known as unit operations. Some of these operations are also common to the petroleum and coal products industry (SIC 29). SIC 29 is listed in the classification manual as including establishments primarily engaged in petroleum refining, manufacturing of asphalt paving and roofing materials, and compounding of lubricating oils and greases from purchased materials. However, only petroleum refining itself will be considered in this report. Three 3-digit SIC subdivisions are listed ir Table 5.1 for the petroleum industry.

\subsubsection{Energy Consumption in Chemical and Petroleum Refining}

Energy consumption in the chemical and petroleum refining industries is changing rapidly because of technical improvements brought about by increased competition and energy costs. Because of these changes, the data presented here are from the 1981 Annual Survey of Manufactures (ASM) (Bureau of Census 
IABLE 5.1. Purchased Energy Consumption in the Chemical and petroleum Refining Industries (in 1931 )

\begin{tabular}{|c|c|c|c|}
\hline SIC \# & Classification Name & $\begin{array}{c}\text { Furchased } \\
\text { Egergy } \\
\left(10^{12} \text { atu }\right)\end{array}$ & of Total \\
\hline 281 & Industrial Inorganics & 562 & 21.4 \\
\hline 282 & Plastic Materials and Synthetics & 418 & 15.9 \\
\hline 283 & Drugs & 77 & 2.9 \\
\hline 284 & Soaps, cleaners, Tojlet Goods & 55 & 2,1 \\
\hline 285 & Paints and Allied products & 16 & 0.6 \\
\hline 286 & Intustrolal Organics & 1042 & 39.6 \\
\hline 287 & Agricultural chemicals & 367 & 14.0 \\
\hline \multirow[t]{2}{*}{289} & Missellangous & Q2 & 3.5 \\
\hline & Total & 2629 & 100.0 \\
\hline 291 & Petroleurn Refining & 1064 & 93.6 \\
\hline 295 & Paving and Roofing Materials & 58 & 5.1 \\
\hline \multirow[t]{2}{*}{299} & Miscellaneous & 15 & 1.3 \\
\hline & Total & 1137 & 100.0 \\
\hline
\end{tabular}

1981), rather than 1977 Census of Manufactures (Bureau of Census 1981), used in the other chapters of this analysis. Although the ASM is incomplete in comparison with the 1977 Census of Manufactures (Bureau of Census 1981), the latest census avallable, it includes some of the changes in recent years.

The ASM presents data on consumption of purchased fuels plus electricity generated and used on site. The refinery industry, in particular, burns considerable portions of its process stream (which is not a purchased fuel) for energy, so this purchased energy information dots not give the total energy consumption. However, as discussed later, it does include the energy flows of tribological importance.

Purchased energy consumption in the chemical industry was about 2.6 quad in 1981. Two major subclassifications producing basic chemicals, the industrial organics and industrial inorganics sectors, consumed close to two-thirds of this total. Petroleum refining consumed $93.6 \%$ of the 1.1 quad of energy 
consumed by the petroleum and coal products industry. Energy consumption for each three-digit classification in the chemical and petroleum refining industries is shown in Table 5.1 .

A significant proportion of the purchased energy consumed by both the chemical and petroleum refining industries is natural gas. In the chemical industry, natural gas comprises $56 \%$ of the total, followed by electricity with 17.2 2 , coal with $14.1 \%$, and fuel oil with $5.7 \%$. Refineries consume $79.5 \%$ latural gas, $9.8 \%$ electricity, 5.4\% fuel ofl and almost no coal. Table 5.z details this distribution.

Bectricity is an energy form of particular interest for this study because of its use to drive motors, which power a variety of machines. Both the cherpical and petroleum refining industries generate considerable amounts of power themselves. The purchased and generated electricity in 3-digit SIC subtassifications of both industries is detalled in Table 5.3. As shown in the table, the subclassifications of industrial organics and industrial

\section{IABLE 5.2. Purchased Energy Consumption by Fuel Type in the Chemical and Refining industries}

\begin{tabular}{|c|c|c|c|}
\hline Industry & Fuel & $10^{12} 8 t u$ & * of Total \\
\hline \multirow[t]{6}{*}{ Chemical } & Coa! & 370 & 14.1 \\
\hline & Fuel oil & 151 & 5.7 \\
\hline & Natural gas & 1472 & 56.0 \\
\hline & Electricity & 452 & 17.2 \\
\hline & Other and for Nat & 185 & 7.0 \\
\hline & spectitles & 2630 & 100.0 \\
\hline \multirow[t]{7}{*}{ Petroleum Refining } & Coal & 5.76 & 0.5 \\
\hline & Fuel 017 & 61.8 & 5.4 \\
\hline & Natural Gas & 893 & 78.5 \\
\hline & Liquid Petroleunt Gas & 9.04 & 0.8 \\
\hline & Electricity & 11.1 & 9.8 \\
\hline & other and/or Not & 56.4 & 5.0 \\
\hline & Total & 1037.1 & 100.0 \\
\hline
\end{tabular}


TABLE 5.3. Electricity consumption in the chemical and petroleum Refining Industries $\left(\mathrm{kWh} \times 10^{\circ}\right)$

\begin{tabular}{|c|c|c|c|c|c|}
\hline $510 \#$ & Nane & $\begin{array}{c}\text { Electricity } \\
\text { Purchased }\end{array}$ & $\begin{array}{l}\text { Wectricity } \\
\text { Generated } \\
\text { and Used }\end{array}$ & $\begin{array}{c}\text { Electricity } \\
\text { Used } \\
\end{array}$ & $\begin{array}{l}\% \text { of } \\
\text { Total }\end{array}$ \\
\hline 281 & $\begin{array}{l}\text { Industrial } \\
\text { inorganics }\end{array}$ & 60,110 & 3,143 & 63,253 & 44.4 \\
\hline 282 & $\begin{array}{l}\text { Plastics and } \\
\text { Synthetics }\end{array}$ & 21,287 & 1.406 & 22.693 & 15.9 \\
\hline 283 & Drugs & 4,673 & wa) & $m-m$ & -- \\
\hline 284 & $\begin{array}{l}\text { Soaps, Cleaners, } \\
\text { rollet Goods }\end{array}$ & 2,294 & $W$ & $m$ & $\rightarrow$ \\
\hline 285 & $\begin{array}{l}\text { haint and } \\
\text { Allied products }\end{array}$ & 878 & $W$ & $-m$ & -- \\
\hline 286 & $\begin{array}{r}\text { Industrial } \\
\text { organics }\end{array}$ & 30,135 & 4,733 & 34,660 & 24.5 \\
\hline 287 & $\begin{array}{l}\text { Agricultural } \\
\text { Chemicals }\end{array}$ & 9,920 & 570 & 10,490 & 7.4 \\
\hline \multirow[t]{2}{*}{289} & Niscellaneous & 3,041 & 193 & 3,234 & 2.3 \\
\hline & & 132,330 & 10,045 & 137.538 & 94,5 \\
\hline 2911 & Petroleun Refining & 30,964 & 5.420 & 36,384 & 95.8 \\
\hline 295 & $\begin{array}{l}\text { Paving and } \\
\text { Poofing Materials }\end{array}$ & 1,238 & 17 & 1,255 & 3.3 \\
\hline \multirow[t]{2}{*}{299} & Miscellaneous Petroleum & 344 & -- & 344 & 0.9 \\
\hline & & 32,546 & 5,437 & 37,983 & 100.0 \\
\hline
\end{tabular}

(a) Witheld to avoid revealing information abuut individual companies.

inorganics consume about two-thirds of the total. Refining consumes almost $96 \%$ of the electricity consumed in petroleum and cod products.

One important factor in any analysis of that chemical industry is its extrene diversity. Hundreds of thousands of chemicals are produced by thousands of distinct processes. Often the same pruduct ls produced by different 
processes in different plants. Large proportions of the energy, however, are consumed in the basic industrial organics and inorganics sectors in producing very basic chemical products. The top 50 of those products in 1983 , by pounds of production, are shown in Table 5.4. Petroleum refining is somewhat more uniform, but differences in the quality of the crude feedstock and the required output product mix cause difficulties in making generalities about this industry as well.

\subsubsection{Industry Activities}

The chemical and petroleum refining industries generally have their processes designed and analyzed by unit operations. These unit operations are basic reaction, mixing, crushing or other steps in the sequence of operations leading from feedstock to final product. There are many unit operations, and many ways they can be combined into a process. As noted previously, often several processes can be used to manufacture the same product from the same feedstock. The process used is primarily based on the its relative economics, which depend on the process design, local factors such as the availability of cooling water or electricity, and even the size of the planned installation. Many plants for basic chemicals are huge because the material cannot be produced cheaply enough on a small scale to be competitive.

The chemical industry's diversity makes analyzing a particular type of energy loss (e.g., tribology) exceedingly difficult. Information on friction and wear is not routinely available, and the day-to-day energy consumption of that friction and wear is not usually of concern to the industry. Most of the energy consumption in the industry is for process heat and is derived from gas, oil, coal, and other fuels. Any tribological losses generally form part of the electrical energy use, as noted earlier, because electric motors are used for most shaft drives. Use of engines and turbines for purposes other than electricity generation in the chemicals and refining industries is ignored in this situdy. Also, it is assumed that all electric power generation is by turbines rather than engines. Therefore, in the analysis of tribological losses, electrical energy consumption data must be used, which are available for various 4-digit SIC subsections of the chemicals industry and for petroleum refining. 
TARLE 5.4. Top 50 Chemical Products in 1983 (in pounds of nutput)

\begin{tabular}{|c|c|c|}
\hline Rank & Produset & $\begin{array}{l}\text { Output } \\
\text { (billions of } 1 \mathrm{~b}) \\
\end{array}$ \\
\hline l & Sulfuric Acid & 69.45 \\
\hline 2 & Nitrogen & 42.03 \\
\hline 3 & Lime $(n)$ & 28.80 \\
\hline 4 & nxygen & 28.73 \\
\hline 5 & Ethylene & 28.59 \\
\hline 6 & Ammonia & 27.37 \\
\hline 7 & Sodium hydroxide & $? 0.46$ \\
\hline 8 & Chlorine & $19.9 ?$ \\
\hline 9 & Phosphoric acid & 19.90 \\
\hline 10 & Sodium carhonate ${ }^{\text {e }}$ ? & 16.93 \\
\hline 11 & Nitric acin & 14.75 \\
\hline $1 ?$ & Propylene & 13.98 \\
\hline 13 & Ammoni um nitrate $\{g\}$ & 13.24 \\
\hline 14 & Urea ${ }^{(n)}$ & 11.54 \\
\hline 15 & Ethylene dichloride & 11.25 \\
\hline 16 & Renzene & 9.48 \\
\hline 17 & Ethy lhenzene & 7.96 \\
\hline IR & Carhon dipxide(k) & 7.15 \\
\hline 19 & Toluene & 7.12 \\
\hline 20 & Styrene & 6.99 \\
\hline 21 & Vinyl chloride & 6.95 \\
\hline $2 ?$ & Methanol & 6.62 \\
\hline 23 & Terephthalic acid (m) & 5.69 \\
\hline 24 & Fthyleng nxide & $5.5 \%$ \\
\hline 25 & xylene & 5.57 \\
\hline
\end{tabular}

\begin{tabular}{|c|c|c|}
\hline Rank & Product & $\begin{array}{l}\text { Output } \\
\text { (nillions of } \mathrm{in} \text { ) }\end{array}$ \\
\hline 26 & Formal dehyde $(a)$ & 5.40 \\
\hline 27 & Hydrochloric acid & 5.22 \\
\hline $2 \mathrm{H}$ & Ethylene glycol & 4.46 \\
\hline 29 & $p-x y l e n e$ & 4.11 \\
\hline 30 & Ammonium sulfate & 3.94 \\
\hline 31 & r.umene, & $3.3 n$ \\
\hline 32 & Potash $(c)$ & 2.87 \\
\hline 33 & Acetic, acid & 2.70 \\
\hline 34 & Phenol(त) & $? .61$ \\
\hline 35 & Carbon bląck & 2.50 \\
\hline 36 & Rutadiene $(f)$ & $? .31$ \\
\hline 37 & Alumínum sulfate & 2.29 \\
\hline 38 & Acrylnnitrile & 2.15 \\
\hline 39 & Vinyl acetate & 1.96 \\
\hline 40 & Calcium chloride ${ }^{(i)}$ & $1.8 R$ \\
\hline 41 & Acetone & 1.87 \\
\hline 42 & Sodium sulfate $\mathrm{e}^{(j)}$ & 1.71 \\
\hline 43 & Cyclohexane & 1.69 \\
\hline 44 & Propy lene oxide & 1.58 \\
\hline 45 & Titanium dioxide & 1.51 \\
\hline 46 & Sodium silicate & 1.45 \\
\hline 4) & Adipic acid & 1.42 \\
\hline $4 B$ & Sodium tripolyphosphate & 1.34 \\
\hline 49 & Tsonronyl alenhol & 1.21 \\
\hline \multirow[t]{3}{*}{50} & Ethanol & 1.10 \\
\hline & $\begin{array}{l}\text { Total Organics } \\
\text { Total Inorganics }\end{array}$ & $\begin{array}{l}165.17 \\
333.41\end{array}$ \\
\hline & GRAND TOTAL & 498.62 \\
\hline
\end{tabular}

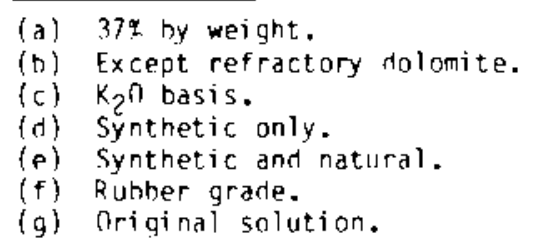

(h) 100 q hasis.

(i) Solid and iiquid.

(j) High and low purity.

(k) Liquid and soliat only.

(l) All grades.

(m) Inclutes both acid and ester without double counting.

Sources: Rureau of Mines, International Trade Comission, C\&EN estimates 
The industry activities that use electricity are falty limited compared to those that use heat, but they still must be generalized to make this analysis manageable. The final categorizations chosen for examination are turbines, pumps (of all types), compressors, blowers, mixers and agitators, grinders, centrifuges, conveyors, packaging machines, and other mechanically complex devices. These categorizations are obviously gross simplifications because there are thousands of types and sizes of pumps, for example. Without careful study of specific industrial processes, however, further subdivision of the categories is not possible. Also, these categories were not chosen because they were all suspected of being very important tribological sinks. For example, centrifuges, of course, must run very smoothly and are therefore aready very carefully designed tribologically and do not stand out as a posstble area of large loss.

Given the categorizations, the next step of the analysis is to establish a relationship between tribological estimates made on an individual-piece-ofequipment level and the data for electricity use by various sectors of the chemical and petroleum industries. This step is very jomportant and difficult. l.oss estimates highly depend on the process in which a piece of equipment is used. Various processes have various types of mechanical and nonmechanical equipment that uses electricity. Relating equipment and energy use information, whout ted tus process-by-process evaluations of the whole industry, requires careful planning and gathering of avallable data. The approach taken -n this study is outlined in the next section.

\subsection{PROCESS ANALYSIS APPDOACH}

To determine tribological losses from the electricity data requires a simplifiad set of nodels for processes taken to be representative of the chemical industry. For this preliminary review, two approaches were possible. The -irst was to generate several generic processes that roughly typify the characterist'cs of basit types of steps taken in chemical manufacturing and the general methodology for petroleum refining. These processes might include those involving a great deal of solids handling, those involving largely gases, or those involving a great deal of mixing. 
A second approach was to use published models of industrial processes. A useful set of processes is contained in work conpleted by Drexel lniversity for the Department of Energy (DOE) in the late 1970s (Hamel and Brown 1979). The report of that work contains information on 48 important chemical processes and on petroleum refining. The chemical processes belong to 14 different 4mdigit SIC subclassifications in which electricity data are available (listed in Table 5.5. Because of this subclassification, an approach using the Drexel models was chosen.

TA8LE 5.5. Chemical processes in "whe Drexel Data Base

SIC Numbers 281

2812

2813

2816

2819

282

2821

2822

2823

2824

283

2834

286

2865

2869

287

2873

2874

289

2899

291

\section{1}

Industry subclassification

Industrial Inorganics

Alkalles and chlorine (5 processes)

Inorganic Gases (3 processes)

Inorganic pigments (5 processes)

Industrial Inorganfe chentcals 5 processes)

plastic Materials and Synthetics

plastic Materials and Resins (5 processes)

Synthetic Rubbers (5 processes)

Cellulosic Man-Made Fibers $(5$ processes)

Non-Cellulosic Organic Fibers (5 processes)

urugs

pharmaceutical preparations

industrial organics

Cyclic Crudes and Intermediates (3 processes)

Industrial Organic Chemicals (3 processes)

Agricultural Chemitals

Nitrogenous Fertillyzers

Phosphatic Fertillzers (4 processes)

Miscellaneous

Chemical Preparations Not Elsewhere Classified (2 processes)

Petroleum Refining

Petroleut Refining 


\subsubsection{Drexel Industrial Process Data}

The Drexel information was reviewed by the Electric Power Research Insti tute (EPRI) as part of a study of industrial energy data bases (Isser and limaye 1982). Some of the points made in that report are a good preface to this study's effort to use the Drexel data in tribological assessments. EPRI's data base was developed as part of a waste energy study. To obtain information for that data base, handbooks, previous energy conservation studies and indusiry periodicals were used. Because the models are synthesized as typical rather than as exemplars, no documentation is given. Perhaps because the 1)rexel work was originally intended for waste energy studies, in some cases information on electricity is questionable. The most noticeable problems, however, are in cases of electricity self-generation and may not affect consumption estimates. The Drexel study is criticized because it presents a level of detail that often does not logically hold together and certainly is not substantiated in the report. For brief data manipulation efforts such as this study, however, it is the best information available.

As noted above, the Drexel data cover 48 processes in 14 subdivisions of the chemical industry. The 12 other subdivisions at that level of classification (4-digit SIC) each consume much less electricity than the 14 categories. Information from energy use and chemical process guides (Shreve and Brink 1977) was used to combine the electricity distribution among pumps, compressors, etc., in the 48 processes into distributions for the 14 SIC categories. The 12 minor categories were mostly finished goods (soaps, fertilizers) requiring high-tribological-loss packaging and finishing operations. They were therefore conservatively evaluated using the average electricity distributions from the 14 more basic SICs.

\subsubsection{Tribological Loss Estimation}

The most basic and important step in this analysis was estimating tribological losses in the categories of equipment listed above. This estimation was very difficult because overwhelming generalizations had to be made about parameters that are very important to tribology. For example, a wide variety If types of pumps that have many different bearing arrangements and friction and wear parameters are being used. These types can be discussed separately, 
but to extrapolate losses on a nationwide, multiprocess level, very broad estimates were required. The wide variety of materials being pumped was equally a problem. Similar concerns arise for other types of equipment. Investigating tribological losses in the chemical and petroleum refining industries is therefore severely hampered if its results are to be extrapolated beyond a very specific range of equipment and processes. This overview was hampered almost to the point of dysfunction by its very broadness. The estimates of direct tribological losses as a function of electric power consumption given in the next section must therefore be treated as only an attempt at quantification. The summary section briefly discusses indirect losses.

\subsection{DIRECT TRIBOLDGICAL LOSSES FOR CHEMICAL PROCESS EQUIPMENT}

This section contains assessments of a simplified and generalized subset of chemical and refining industry equipment that: is applied to a wide range of chemical processes. Turbines will be discussed first because they are the only tribologically important piece of equipment under study here that is not driven by electricity; they are used for producing the electricity. Electric motors, which drive the remainder of the equipment, are then reviewed for losses. Finally, pumps (of all types), compressors, fansi and blowers, mixers and agitators, grinders, centrifuges, and conveyors and other mechanically complex devices are discussed.

\subsubsection{Turbines}

Turbines have many sources of losses. Some of these losses are fluid mechanical, such as blade tip blow-by or other turbulent phenomena. Others sources develop over time because of blade degradation from erosion, deposition or corrosion. Erosion (which is a tribological phenomena) is a severe problem in research gas turbines burning dirty fuels but: is a less serious problem in steam or natural gas turbines, which are genera'ly used in the chemical and refining industries. Utility steam turbines require regular rebuilding as well, but how closely utility procedures correspond with the situation in the chemicals industry is unknown, so indirect tribological losses in turbines will not be discussed. 
Direct losses estimated for the utility turbines (Pinkus and Wilcock 1977) will be discussed, however. These large turbines generally have 10 sleeve-type fluid film bearings and 2 thrust bearings with journals 1 to 2 feet in diameter, running at 3600 rotations per minute (rpol). These bearings usually run in the turbulent regime, with losses of $0.5 \%$ of plant output. The smaller turbines in industrial generating sets wll certainly have higher losses than the utility turbines, so these estimates are conservative.

\subsubsection{Electric Motors}

The electric motor industry is highly standardized, and data on motor Inefficlenctes are readly available. Most of the losses in a standard motor are not related to tribology-only $5 \%$ of the losses are attributable to friction in the motor and windage through the casing; about one-third to one-haif of this can be attributed to bearing friction alone. Motor efficiency depends on motor size and varies at full load from $83 \%$ for 1 horsepower, 3-phase, 4-pole energy-efficjent motors to 94.5 for 200 horsepower motors (Andreas 1992):

Given that many of the motors in the chemical and petroleum refining industries are large but may not be of this energy-efficient type, an overall efficiency of $90 \%$ can be assumed. Losses due to tribology are then about 0.2\% of power input. Many motors do not run at full load all the time: the chemical industry is investing heavily in adjustable speed drives because this significantly icreases efficiency. The adjustable speed drives increase tribological losses, however, so the simplified andysis presented here is conservative. 41so. this motor loss is much lower than the tribology loss in the device being Iriven, so much lower that it is well within the uncertainty of the loss estiinate for a given device. Therefore, it is not added to the device estimates in this analysis because they are only round number figures. This further anhances the conservatisn of the results.

\section{3 .3 Pumps}

Two major types of pumps are used in the chemical and petroleum refining Industries-mentrifugal and reciprocating pumps. The former are the workhorse of the industry, while the latter are especially useful when high pressures are 
needed and the intermittent nature of the pumping is not a problem. Centrifugal pumps are made in a considerable variety of types and sizes. They may be horizontal or vertical, single or double suction, and single or multistaged. Capacities are available up to 600,000 gallons per minute and horsepowers up to 65,000 (Evans 1976). These pumps are often oversized in installations because of the possible need to start with a full load of fluid.

Efficiency depends on sizing and many fluid mechanical effects, as well as tribological effects (Matley 1979). The latter include bearing friction, seal friction and efficiency reductions due to erosion of the pump impeller. The latter effect is probably the most important. [uring the initial weeks of operation, erosive damage to the impeller can alter the geometry of the impeller contours. This change can reduce pump efficiency by $5 \%$ or more. Once the change occurs, the new geometry is maintained or further degraded for the rest of the pump's life.

Reciprocating pumps can provide high-pressure output quite readily and are available in many different forms. Their operating characteristics are inflexible, however, and in many pumping situations they have lower overall efficiency than centrifugal pumps ( $50 \%$ to $90 \%$ ). Larger pumps with more sophisticated designs are more efficient. Seal friction is the most important tribological loss because seals are tight packages. The losses in the packing can be more than $5 \%$ in some cases. Leakage past: the seals as the result of wear can increase losses proportionally to the flow rate of the leak. Most leakage situations are very small percentages of pump capacity, however.

Considering the diversity of types of pumps and process situations encountered, $4 \%$ of pump power was conservatively estimated to be lost by various tribological mechanisms. Indirect losses are very difficult to assess because wear is a function of both pump design and the product handled. Wear is very important, however. Bearings apparently cause problems in many process industry centrifugal pumps. Thirty percent of all centrifugal pump failures can be traced to the failure of rolling element bearings (Barnard and Sowrey 1984). The indirect loss implications of this are not known, however, because they depend on the distribution of failures throughout industry. 


\section{3 .4 Compressors}

There are two basic types of compressors, dynanic and positive displacement compressors, which correspond to centrifugal and reciprocating pumps. There are two classes of dynamic compressors and four general types of positive displacenent compressors, but they were not separately analyzed for tribologital lossas. In all compressors, erosion wear can be significant if the gases being processed are not free of liquids and abrasive particles, and if the erosion : s severe, it can degrade performance as well as shorten operating ifetimes. The most important direct energy losses in compressors were from shaft and other types of seals (Matley 1979), which are more complex in compressors than in pumps because gases escape much more readily. In many cases, eakage has only a minor effect on efficiency, however, and after the range of compressors and likely gas streans were considered, tribological losses were siet at ato of power input.

\subsection{B owers}

Blowers, whether the axial or centrifugal configuration, basically act as large fans and are used to move large volumes of air at close to atmospheric pressure. For example, they provide inlet air for process furmaces and drive exhausts. Many fluid mechantcal losses occur in a blower, but tribological losses are relatively snall. Friction losses occur in the transmissions used between hotor and fan and vary between $2{ }^{*}$ and $5 \%$ (Matley 1979), but nany blowers do not use transmissions. Bearing losses alone are qut te low, only slightiy greater than those for the electric motor. Therefore, an overall estimate for the loss was set at $1 \%$ of input power.

\section{3 .6 Mixers and Agitators}

Several different types of mixers are used in the chenical industry. kgltators will not be distingushed from mixers in this study because the tritological concerns are similar. The mixers range from small portable machines clamped cnto open tanks, to sidementering devices used for blending, to heavy duty, multiple-stage top-entering machines. As with blowers, the primary source of tribological loss is the transmission used to keep the patdle speed lower than motor speed. Its amplitude depends on the type of transmission and 
extent of reduction necessary. A value of 1 of input energy was selected based on moderate speed reductions in industrial quality transmissions.

\section{3 .7 Centrifuges}

Centrifuges are important devices for extracting liquid from process materials without heating them, as for example, when separating suspensions. The centrifugal forces that accomplish the task depend on speed of rotation of the centrifuge drum, and they therefore rotate at yery high speeds on carefully destgned bearings. Their tribological losses can be estinated to be at least comparable to those for steam turbines, or $0.5 x$ of power input.

\section{3 .8 Crushing and Grinding}

Crushing and grinding operations occur in the plastics and inorganis chemicals industries, in making drugs, and in other chemical applications. The estimate for the tribological losses of $1.75 \%$ of input power, as developed in the mining thapter, was used here also.

\section{3 .9 Conveyors, Packagers, Balers, and Other Complex Dexices}

Conveyors are used in occastonal solfdsmanding appllcations in the chem icals industry, as well as in other industries discussed in this report. There are many types of conveyors, including strew conveyors, bucket elevators, bucket carriers, and roller belts. The type used depends on the distances and other transport needs and the solid being transported. More detail is given in Chapter 7.0 on the food processing industry. Industrial sources give sof input power as an accurate estimate for friction losses in conveyors. These losses occur in bearings and rollers, in pins and bushings in chains, among elements in unit conveyors, and in contacts with adjacent surfaces. Losses in packaging devices, balers, and other complex machines are estimated to be at the same 5 level because of similar types of frtction.

\subsection{SUMMARY AND CONCLUSIONS}

The analysis methodology and assumptions about direct tribological losses developed in this study were used to calculate the tribological losses in the chemical and petroleum refining industries. These results are shown in Table 5.6. Descriptive material on possible tribological mechanisms was also 
TABLE 5.6. Loss Mechanisms in the Chemical and Petroleum Refining Industries

\begin{tabular}{|c|c|c|c|}
\hline Process Equipment & Friction & Erosion & Abrasi \\
\hline \multicolumn{4}{|l|}{ Compressors } \\
\hline $\begin{array}{l}\text { Radial Flow Centrifugal } \\
\text { Axial Flow Centrifugal } \\
\text { Reciprocating } \\
\text { Rotary }\end{array}$ & $\begin{array}{ll}2 \\
y \\
y \\
y\end{array}$ & $\gamma$ & $\checkmark$ \\
\hline \multicolumn{4}{|l|}{ Fans and Blowers } \\
\hline $\begin{array}{l}\text { Axial Flow } \\
\text { Centrifugal Flow }\end{array}$ & 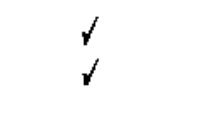 & & \\
\hline \multicolumn{4}{|l|}{ Pumps } \\
\hline $\begin{array}{l}\text { Reciprocating } \\
\text { Rotary Positive Displacement } \\
\text { Certrifugal }\end{array}$ & 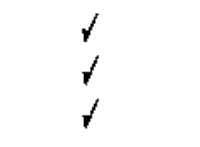 & $\begin{array}{l}2 \\
y \\
y\end{array}$ & $\checkmark$ \\
\hline Mixers & r & 1 & \\
\hline Centrifuges & $\checkmark$ & & \\
\hline Crushers, Mills and Grinders & $\checkmark$ & & $\checkmark$ \\
\hline Conveyors, Packagers, Balers, etc. & $\sqrt{1}$ & & $\checkmark$ \\
\hline Turbines & $\checkmark$ & 1 & \\
\hline
\end{tabular}

collected and is summarized in Table 5.7. Table 5.7 is not strictly comparable with similar tables in other chapters in this report, however. The industries under study are too varied for it to be complete.

The variety in the industries makes analyzing specific types of losses (e.g., tribological) very difficult. Too many kinds and sizes of equipment and kinds of process streams exist to count the details of each, even if such information were available. These details are not available, however, because specific information on processes is often a closely guarded industrial secret. This preliminary effort used estimates and assumptions at several stages of the analysis to determine tribological losses in chemicals and petroleum refining. They are listed here as an aid to those using the results of this study or wishing to improve upon it. In the order in which the estimates and assumptions were made in the analysis process, they include the following: 
TABLE 5.7. Direct Tribological Losses in the Chemical and Petroleum Refining Industries

\begin{tabular}{|c|c|c|c|}
\hline Process Equipment & $\begin{array}{c}\text { Energy } \\
\text { Consumed }\end{array}$ & $\begin{array}{l}\text { Tripological } \\
\text { Loss (a) } \\
\end{array}$ & $\begin{array}{l}\text { Total Energy } \\
\text { Loss }\left\{10^{12} \text { Btu }\right\}\end{array}$ \\
\hline Compressors & Electricity & 4 & 2.48 \\
\hline Fans and Blowers & Electricity & 1 & 1.99 \\
\hline Pumps & Electrictity & 4 & 6.93 \\
\hline Mixers & Electricity & 1 & 0.153 \\
\hline Centrifuges & Electricity & 0.5 & 0.0546 \\
\hline $\begin{array}{l}\text { Crushers, Mills, } \\
\text { and Grinders }\end{array}$ & Electricity & 1.75 & 0.464 \\
\hline $\begin{array}{c}\text { Conveyors, Balers, } \\
\text { Packagers, etc. }\end{array}$ & Electrictly & 5 & 0.805 \\
\hline Turbines & $\begin{array}{l}\text { Varlous } \\
\text { fossil fuels }\end{array}$ & 0.5 & 0.2667 \\
\hline
\end{tabular}

- Estimates - Percentage of power input or output attributable to tribology.

- Assumption - Only implements driven by electric motors are significant.

- Assumption - All electricity generation is by turbine-driven generators.

- Estinates - Drexel study process energies.

- Estimates - The contributions nrexel processes make to full a-digit SIC classifications in which electricity use data were awailable.

- Assumption - The 4-digit SIC groups for which Drexel data were not avallable could be evaluated using averaged data from other processes.

- Uncertainties - In 1981 Annual Survey of Manufactures data, which are from a statistical survey and not a complete census.

Many of these estimates and assumptions ars purposely conservative. Some of the uncertainty in the estimates could be renoved by a much more thorough 
study of the industry, which would probably find somewhat enlarged tribological sinks. Such an effort would involve building a chemical process industry data base, however.

Within the limitations of the current analysis, the direct loss results show that tribological losses from a particular sink basically depend on how prevalent that sink is in the industry. None of the devices examined had a huge percentage of tribological losses. For this reason, pumps, which are universal in the chemical and petroleum refining industries, contribute over half of the direct tribological energy 10ss. Compressors, blowers and mixers are also big contributors, while less common operations like crushing, convey-ng and packaging have smaller tribological losses. Centrifuges, as might be expected, provide only a very small $(<0.5 \%)$ contribution to the losses from these electric-motor-driven devices. Analysis of nonelectric devices was restricted to turbine-generators, which have a relatively minor tribological contribution on the same order as crushers. Unlike most of the electrically driven equipment, turbines, of course, are not specific to the chemical - ndustry.

Indirect losses are probably impossible to calculate with any accuracy. No attempt was made to do so in this analysis. Material wear is common for rotor-driven components in the industry, however. Many equipment failures are due to tribological causes. In the petroleum refining industry, for instance, $30 \%$ of all pump failures are caused by the fatlure of rolling element bearings (Barnard and Sowrey 1984). In addition to the indirect energy losses from equipment, replacement, large energy costs result from process shutdowns for overhauls, especially if they are unscheduled. The reliability of process plant equipment is of paramount importance because many plants run 24 hours a day. Chemical and petroleum industry interest in tribology is based more on these indirect energy and production concerns than on direct losses. 


\subsection{REFERENCES}

Andreas, 4. C. 1982. Energy-Efficient Motors. Marcel Dekker Inc., New York, New York.

Barnard, P. C. and R. B. Sowrey. 19B4. "Elimination of Bearing Housing Contamination in General Purpose API Centrifugal Pumps." Lubrication Engineering. $40(5): 285$.

8ureau of the Census. 1981. Annual Survey of Manufacturers: Fuels and Electric Energy. MS1(As)-4.1, 1.5. Department of Comerce, Washington, D.C.

Evans, F. L. 1976. Equipment Design Handbook for Refineries and Chemical Plants. 2nd. Ed. Galf Publishing Co, Book Division, Houston, Texas.

Hamel, B. B. and $H_{*}$ 1. Brown. 1979. Energy Analys is of 108 Industrial Processes. Drexel Universtty. Philadelphia, Pennsyluanta.

isser, 5. and 0. R. Limaye. 1982, Review of Industrial Energy data Gases. EPRI Report EM-2647, Electric Power Research Institute, Palo Alto, California.

Matley, J, 1979. Fluid Movers. Chemical Engineering, McGraw Hill, New York, New York.

Pinkus, 0. and D. F. Wilcock. 1977. Strategy for Energy Conservation through Tribology. ASME Research Committee on Lubrication, New York, New York.

Shreve, R. N. and J. A, Brink, Jr. 1977. Chenical Process Industries, McGraw Hill, New York, New York. 


\subsection{PULP AND PAPER}

In this chapter, total energy use and tribological losses in the pulp and paper industry are identified and characterized. Energy consumption is speci fied by fuel type for each of the major pulp and paper sectors, and total whergy consumption is compared to purchased fuels and electricity. The major processes and products of the pulp and paper industry are briefly described, and those processes identified as having significant tribological losses are reviewed and described in more detail. The nature of each tribological sink and the mechanisms leading to direct and/or indirect losses are then characterized. Finally, the estimates of energy losses and the calculational approach taken are identifled. Tribological losses estimated for pulp and paper are sumarized at the end of the chapter.

\subsection{INTRODUCTION}

The pulp and paper industry, as defined for this study, includes businesses engaged in harvesting trees, debarking, cutting, chipping, pulping, and producing paper, paperbard, bullding paper, and building board. This specifically includes logging camps and logging contractors (SIC 2611), pulp mils (SIC 2611), paper mills (SIC 2621), paperboard mills (SIC 2631), and building paper and bullding board mills (Stc 2661). Sawnills and establishments that manufacture paper products from purchased paper were not included in the analysis.

\subsubsection{Energy Consumption in Pulp and Paper}

Purchased fuels and electric energy consumption in pulp and paper totaled 1.2 quads in 1981 according to data presented in the 1982 Census of Manufactures $(1,5$. Census Bureau 1983). IAs of May 1984, the 1981 data are the latest comprehensive energy consumption infomation avallable from the U.S. Census sureau, Paper and paperboard mills dominate the purchased fuels category by combining for over 85 of the total for pulp and paper. Purchased fuels and electric energy consumption are shown for each of the fourmigit classifications in Table 6.1. The energy comsumption data tisted in Table 6.1 and in the 
TABLE 6.1. Purchased Fuels and Electric Energy in Pulp and Paper (1981)

\begin{tabular}{|c|c|c|c|}
\hline 510 & Classification Name & $10^{12}$ Btu & ot Total \\
\hline 2411 & Logging Camps and Logging Contractors & 36.8 & 3.1 \\
\hline 2611 & Pulp Mills & 85.4 & 7.2 \\
\hline 2621 & Paper Mills & 591.4 & 50.0 \\
\hline 2631 & Paperboard Mills & 444.9 & 37.6 \\
\hline \multirow[t]{2}{*}{2661} & Butlding Papar and building Board Mlls & 25.4 & $\frac{2}{2}+1$ \\
\hline & & 1183.9 & 100.0 \\
\hline
\end{tabular}

following tables in this chapter have been derived from the data in the 198 ? Census of Manufacturers (10.\$. Census Bureau 1981).

Purchased energy in pulp and paper is spread fairly evenly among the principal fuel types. Natural gas is the most predominant fuel but still only accounts for about one-third of the purchased energy total. Coal and residual fuel ofl each accounted for a little over $20 \%$ of the total. coal usage has continued its gradual increase of recent years, while residual fuels consumption has declined from that of the late seventies. Distillate fuel oil use has declined to the point where it is no longer a significant fuel. Both natural gas and electric energy purchases have been relatively constant over the past. decade. Purchased energy consumption data by fuel type are presented in Tables 6.2 through 6.7 for the pulp and paper industry and each of its major subdivisions.

In addition to the purchased fuels and electric energy reported by the Census Bureau, $50 \%$ of the total energy consumed in the pulp and paper industry comes frot self-generated sources, such as waste wood (hogged fuel), bark, spent liquor, and hydropower, Table 6.8 sumartzes self-generated energy production for the pulp and paper industry. Nuch less fuel is purchased by pulp mil1s than by paper mills because of the large amount of energy recovered from spent liquors.

\subsubsection{Pulp and Paper Operational Activities}

The production of paper from raw forest products involves three separate stages. First, trees are harvested, debarked, isut, and chipped to produce raw 
TABLE 6.2. Purchased Energy Consumption by Fuel Type in the Pulp and Paper Industry (1981)

\begin{tabular}{|c|c|c|}
\hline Fuel & $10^{12} \mathrm{Btu}$ & \% of Total \\
\hline Electricity & 148.76 & 12.6 \\
\hline Distillate & 14.64 & 1.2 \\
\hline Residual & 263.63 & 22.3 \\
\hline Coal & 243.66 & 20.6 \\
\hline Natural Gas & 390.66 & 33.0 \\
\hline Liquid Petroleum Gas & 1.31 & 0.1 \\
\hline \multirow[t]{2}{*}{ Other and/or Not Specified } & 121.23 & 10.2 \\
\hline & 1183.89 & 100.0 \\
\hline
\end{tabular}

TABLE 6.3. Purchase Energy Consumption by Fuel Type in Logging Camps and Logging Contractors (1981)

\begin{tabular}{|c|c|c|}
\hline Fuel & $10^{12} \mathrm{Btu}$ & \& of Total \\
\hline Electricity & 1.71 & 4.6 \\
\hline Distillate & 8.68 & 23.7 \\
\hline Residual & 1.99 & 5.4 \\
\hline Natural Gas & 0.41 & 1.1 \\
\hline Liquid Petroleum Gas & 0.10 & 0.3 \\
\hline \multirow[t]{2}{*}{ Other and/or Not Specified } & 23.89 & 64.9 \\
\hline & 36.79 & 100.0 \\
\hline
\end{tabular}

TABLE 6.4. Purchased Energy Consumption by Fuel Type in Pulp Mills (1981)

\begin{tabular}{|c|c|c|}
\hline Fuel & $10^{12}$ Btu & \% of Total \\
\hline Electricity & 10.71 & 12.5 \\
\hline Distillate & 0.16 & 0.2 \\
\hline Residual & 35.39 & 41.5 \\
\hline Naturat Gas & 21.42 & 25.1 \\
\hline \multirow[t]{2}{*}{ Other and/or Not Specified } & 17.72 & 20.7 \\
\hline & 85.40 & 100.0 \\
\hline
\end{tabular}


TABLE 6.5. Purchased Energy Consumption by Fuel Type in Paper Mills (1981)

\begin{tabular}{|c|c|c|}
\hline Fuel & $10^{12} B t u$ & \% of Total \\
\hline Electricity & 85.67 & 14.5 \\
\hline Distillate & 3.69 & 0.6 \\
\hline Restidual & 131.75 & 22.3 \\
\hline Coal & 155.91 & 26.4 \\
\hline Matural Gas & 174.83 & 29.5 \\
\hline Liquid Petroleun Gas & 0.74 & 0.1 \\
\hline \multirow[t]{2}{*}{ other anditor wot spectiled } & 38.81 & 6.6 \\
\hline & 591.40 & 100,0 \\
\hline
\end{tabular}

TABLE 6.6. Purchased Energy Consumption by Fuel Type in Paperboard Mills (1981)

\begin{tabular}{|c|c|c|}
\hline Fuel & $10^{12} \mathrm{Btu}$ & of Total \\
\hline Electricity & 47.63 & 10.7 \\
\hline Distillate & 1.63 & 0.4 \\
\hline Residual & 90.78 & 20.4 \\
\hline coal & 87.75 & 19.7 \\
\hline Natural Gas & 180.23 & 40.5 \\
\hline Liquid Petroleun Gas & 0.14 & $-\cdots$ \\
\hline \multirow[t]{2}{*}{ other and or not specified } & $36 * 74$ & 8.3 \\
\hline & 444.90 & 100.0 \\
\hline
\end{tabular}

TARLE 6.7. Purchased Energy Consumption by Fuel Type in Building Paper and Bullding Board Mills (1981)

\begin{tabular}{lccc}
\multicolumn{1}{c}{ Fuel } & $10^{12}$ Btu & of Total \\
\hline Electricity & 3.04 & 12.0 \\
Distillate & 0.49 & 1.9 \\
Residual & 3.72 & 14.6 \\
Natural Gas & 13.77 & 54.2 \\
Liquid Petroleum Gas & 0.33 & 1.3 \\
Other and/or Not Specified & 4.06 & 16.0 \\
& 25.4 & 100.0
\end{tabular}


TABLE 6.8. Self-Generated Fuels in the Pulp

and Paper Industry (1981)

\begin{tabular}{|c|c|c|}
\hline Fuel & $10^{12} \mathrm{Btu}$ & $\mathscr{q}$ of Total \\
\hline Waste Wood & 150.3 & 13.8 \\
\hline Bark & 104.7 & 9.6 \\
\hline Spent Liquor & 816.9 & 75.0 \\
\hline Hydropower & 9.5 & 0.9 \\
\hline \multirow[t]{2}{*}{ Other } & 8.4 & 0.8 \\
\hline & 1089.8 & 100.0 \\
\hline
\end{tabular}

material. Next, cellulose fibers are separated from the wood either by chemical digestion or by mechanical grinding. Finally, the aqueous solution of small cellulose fibers (pulp) is used to form sheets of intermeshed fibers through various drying and pressing operations. The first and last processes have undergone gradual changes in manufacturing technique. The second process, that of producing pulp, has undergone substantial changes in the past 50 years of papermaking.

Pulp and paper are manufactured in two different mill settings, referred to as integrated and nonintegrated mills. Integrated mills produce pulp and paper from pulpwood or purchased wood chips through chemical and mechanical processes that render the solid wood pieces into a fibrous mass known as pulp. These mills tend to be relatively large, with average capacities of about 300,000 tons per year, and are located in areas of ample pulpwood supply and cheap transportation. Nonintegrated mills produce pulp by using waste paper as a source of cellulose fibers, rather than virgin pulpwood. These mills are necessarily located close to sources of waste paper (i.e., in more industrialized areas) and tend to be much smaller, with capacities ranging from 3,000 to 30,000 tons per year (Chiogioji 1979).

Each mill type is associated with a distinct set of tribological loss mechanisms. The process of removing timber, cutting and debarking pulpwood, and finally chipping the pulpwood logs into usable chips relies upon abrasive cutting processes. The process of chopping debris-laden stocks of converted wastepaper for use in nonintegrated mills also requires abrasive cutting, 
although of a different type. Both mill types require pumping of fibrous slurries with possible tribological losses occurring during pumping.

Many other processes in this industry incur wear and friction. In the following sections, the more important tribological loss mechanisms in the pulpmaking and papermaking processes are summarized. Because different processes are used to manufacture different products, a survey of current production figures is first presented, followed by a tribological analysis of the most widely used processes.

\section{1 .3 Industry Product ion Levels}

Paper products include newsprint, printing and writing papers, tissue, packaging paper, and paperboard. Table 6.9 shows production figures for 1980 (Griffin et al. 1984). The product having the largest volume was paperboard used in making corrugated containers and flat boxes, with printing and writing papers having the second largest volume.

The manufacturing processes used to produce paper products have changed significantly. The use of the groundwood process by which cellulose fibers are produced by mechanical grinding decreased from $41 \%$ of the total pulp produced in 1920 to $10.4 \%$ in 1970 . In contrast, the use of the Kraft process by which cellulose fibers are produced by a chemical digestion process increased from $4.9 \%$ of the total pulp produced in 1920 to $69.7 \%$ in 1970 (Anerican Paper Institute 1971). Table 6.10 shows the 1980 figures on wood pulp production by process (Griffin et a1. 1984). According to these statistics, the Kraft and mechanical groundwood processes account for $85.4 \%$ of the total pulp production.

TABLE 6.9. 1980 Paper and Paperhoard Production (Griffin et al. 1984)

\begin{tabular}{lrr}
\multicolumn{1}{c}{ Product } & 1000 Short Tons & \% of Total \\
\cline { 3 - 3 } Newsprint & 4,673 & 7.6 \\
Printing/Writing & 15,219 & 24.7 \\
Tissue & 4,352 & 7.1 \\
Board & 31,524 & 51.2 \\
Packaging/Other & 5,802 & 9.4 \\
\cline { 2 - 3 } & 61,570 & 100.0
\end{tabular}


TABLE 6.10. 1980 Pulp Production (Griffin et al. 1984)

\begin{tabular}{|c|c|c|}
\hline Pulping Method/Source & 1000 Short Tons & of total \\
\hline Sulfite & 1,846 & 3.7 \\
\hline $\mathrm{Kraft} / \mathrm{Soda}$ & 38,586 & 76.3 \\
\hline Serichemical & 4,043 & 8.0 \\
\hline Mechanical & 4,579 & 9.1 \\
\hline \multirow[t]{2}{*}{ Other wood Pulping } & 1,508 & 3.0 \\
\hline & 50,562 & 100.1 \\
\hline Wastepaper & 14,667 & \\
\hline
\end{tabular}

The sulfite process, which produced $41 \%$ of the total volume of wood pulp in 1920, represented only about $3.7 \%$ of the total in 1980.

The Kraft pulping process involves the digesting of the wood chips in a sodium hydroxide/sodium sulfide cooking liquor to remove the lignin, which tinds the cellulose fibers together in the wood. The cooking liquor and hignin is later burned in a kraft recovery boiler to produce process steam. The Kraft process has become predominant for three reasons: a wide variety of wood species can be used; it produces high-quality, bleachable, strong pulp; and the frocess chemicals are less corrosive than those used in the sulfite process.

The groundwood process is almost chemical-free and uses mechanical grinding to produce fibers or fiber bundles. Two processes are typically used. In the first process, debarked logs are loaded against a rotating grindstone, and grinding debris is suspended in wash water to produce pulp. In the second process, wood chips are ground between two rotating disks to produce ground fibers. In both cases, a short precooking process is sometimes used to soften the wood and to reduce the mechanical energy needed to grind the wood*

The sulfite process is a chenical process similar to the Kraft process, although only nonresinous softwoods can be used. The cooking liquor is usually calcium sulfite or bisulfite. A similar process, referred to as neutral sulfite semichemical pulping, uses a hot neutral sulfite solution to soften wood chips prior to mechanical shredding and grinding. This process is used to procuce about 8 of the total amount of wood pulp. 
The three processes ylelding the greatest percentage of pulp were examined for tribological losses: the Kraft process, recycled pulp, and the groundwood grocess. The initial steps of wood chip production and the final process of the paper mat production were also examined. These mechanical and chemical processes are outlined in the following sections of this report.

\subsubsection{Processes lot containing significant Tribological Losses}

In collecting and conplling data on tribological losses in the various processes, several processes were assuned to have little or no tribological losses and therefore were not studied further. These areas are briefly discussed below.

\section{Wood Product Transportation}

The process of removing cut wood from the forest to areas for cuthing and chlpping is performed by trucks and tractors, No attempt was made to determine tribological losses in these conveyance vehicles.

Wood Bark and Fines Transportation

The debarking and pulp separation processes produce wood bark and pulp fines, which are transported by conveyor to conbustors for generating heat. This transport process uses rollers and belts, which may represent al sht tribological 1055. These losses, however, are asumed to be negliglble compared to the relatively severe conditions present in the debarkers.

\section{Energy Recovery processes}

Processes involving the generation of enersy from the burning of process liquers in recovery bollers were not analyzed. These processes are anergy intenslve but are generally tritologically efftcient. Processes using process stean, such as driers, were also considered to be tribologically effictent.

The larger tribological losses were assumed to occur because of the many cutting, debarking, and chipping operations intrinstic to the paper industry. At tempts were made to quantify the losses in processes using these operations. 


\section{6.? ANALYSIS OF TRIBOLOGICAL LOSSES IN THE PULP ANO PAPER INDUSTRY}

Direct and indirect tribological losses were estimated for the various processes used to produce pulp and paper. Direct losses were considered to be actual erergy losses due to attempts to overcome friction, such as motor bearing losses or energy used to remove material through a friction-type process. Indirect losses were considered to be energy lost from removing metal or material from wearing surfaces.

Paper production involves three general subprocesses: wood preparation, pulpmaking. and papermaking. Wood preparation involves converting raw woodstock into uniform bulk feedstock, while the pulpmaking process involves chemically ane mechanically converting the feedstock into pulp. The final process, papermaking, involves the formation of a thin mat of cellulose fibers that are fressed, rolled, and dried into finished paper.

Figure 6.1 shows the main stages of the papermaking process and the products produced at various stages. Debarked pulpwood can be chipped for later digestion or for disk grinding in the groundwood process. Prepared pulp can be processed into paper using several methods, although the fourdrinier process or the cylinder process dominates the industry. Rolls of paper are later cut to shape for shipping. The three main processes are described in the following sections.

\section{2 .1 Wood Preparation}

This section details the losses incurred during tree harvesting, pulpwoad debarking, and pulpwood chipping. Although tree harvesting equipment is available, tree cutting was assumed to be done by hand-held chain saws. The logs are then cut to 4-foot or 8 -foot lengths and are debarked using different debarking techniques. The debarked pulpwood is then chipped for chemical pulp production or ground for groundwood production. Figure 6.2 shows the general processes of wood preparation.

Tres Harvesting

Fulpwood is prepared from harvested trees ranging in diameter from 4 to 24 inches, and from 4 feet to full -grown tree helght. Pulpwood is delivered to 


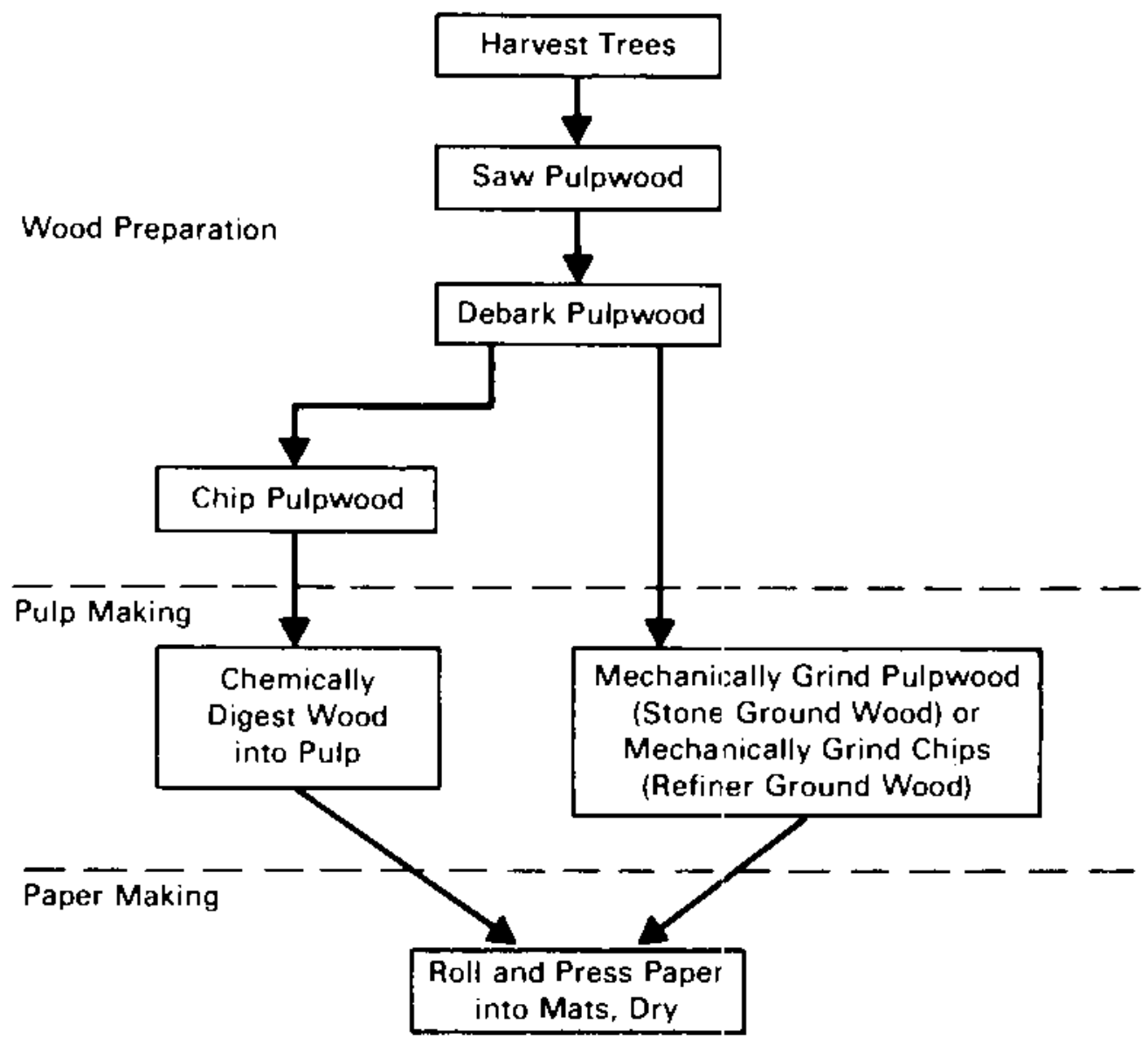

FIgURE 6.1. General Stages o" Paper Making

mills in units of cords, which are each 128 cu lt of stacked wood. (The traditional definition of a cord is a $4 \times 4 \times 8 \mathrm{ft}$ section of stacked wood.) One cord of debarked wood will typically yield $80 \mathrm{to} 90 \mathrm{cu} \mathrm{ft}$ of solid wood, which in turn is converted to 200 to $220 \mathrm{cu}$ ft of loose chips (Merrill 1970). After debarking, the cord will yield between 600 and $; 00$ ib of bark.

Pulpwood density depends upon the type and age of the wood and the location. For young trees, the ayerage density ranges from 25 to $261 \mathrm{~b} / \mathrm{ft}^{3}$. Mature trees show a slightly higher density, ranging from 28.1 to $31.61 \mathrm{~b} / \mathrm{ft}^{3}$. Current logging trends lean toward harvesting young trees, so an estimated average cut wood density is around $271 \mathrm{~b} / \mathrm{ft}^{3}$ (Zobel 1970).

The 1983 harvest figures list $85 \times 10^{6}$ corls of pulpwood consumed (Paper Trade Journal 1985). A large amount of energy :s required to harvest this 


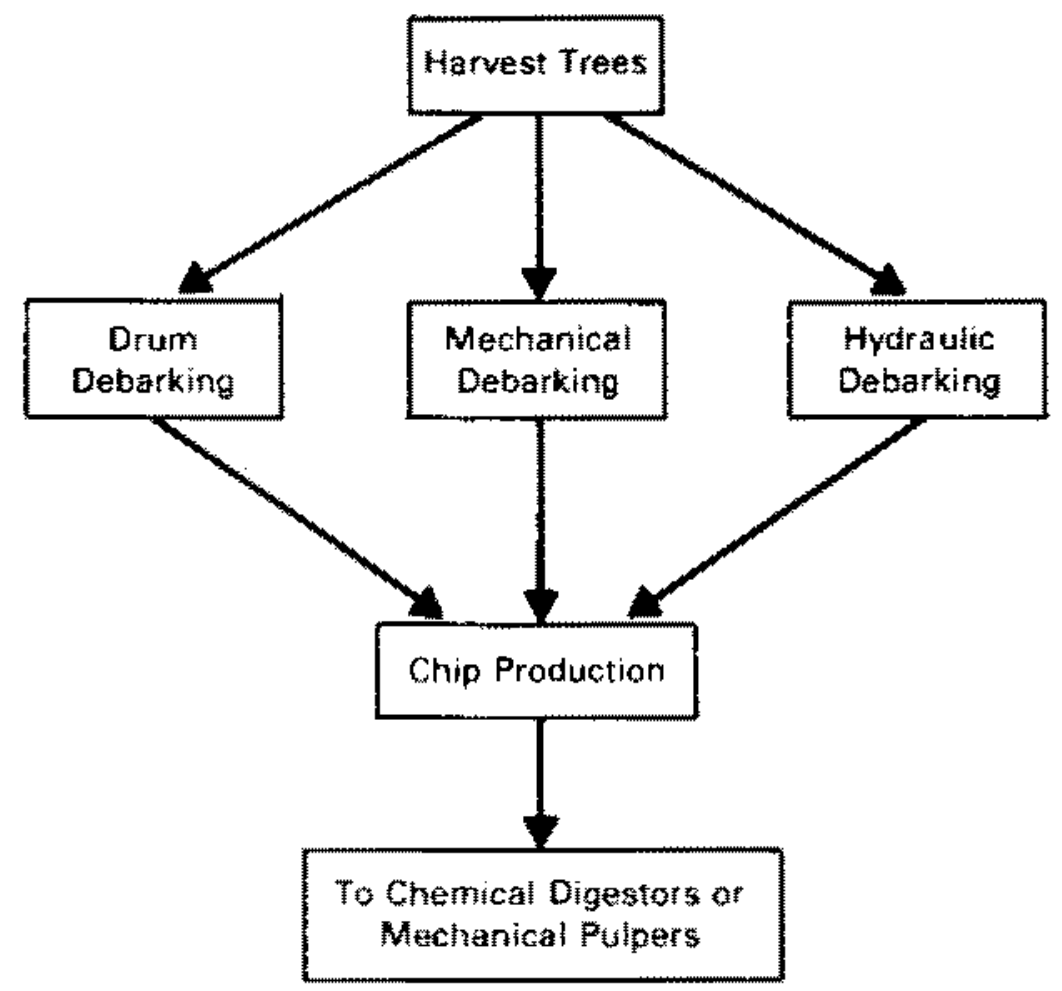

FIGURE 6.2. General Processes of Wood Preparation

wood, primarily because of friction during the cutting process. The direct energy lost by cutting was estimated by estimating the power output of the chain saws used to cut the trees and the time needed to cut the trees into 4-foot sections.

The energy needed to cut the trees was estimated by assuming that 2 people are able to fell and cut five 5-foot dianeter 200 -foot-high trees in one 8-hour shift. This translates into about 150 cords of wood per shift. The chain saw size typlically ranges between 6 to 8 horsepower. Assuming $50 \%$ use and that $50 \%$ power loss due to friction during cutting, the direct loss is estimated co be $1 / 2 \times 1 / 2 \times 2$ people $\times 7$ hp $\times 8 \mathrm{hr} / 150=0.19 \mathrm{hpm}$ hrcord. Assuming thotal pulpwood consumption of $85 \times 10^{6}$ cords, this translates into $4.04 \times 10^{10}$ Btu/yr loss due to friction during cutting. This direct energy loss is due to friction between the chain and the bar and between the saw blades and the wood. Most saws have lubricating systems to minimize these losses and to keep the cotting edges cool. 
Indirect losses due to chain and bar wear were estimated by assuning that the chain is replaced after 40 resharpenings and that the chain is resharpened after every shift. Initial chain weight is estimated to be 2 pounds. The total material loss due to chain wear is estímated as follows:

$$
\begin{aligned}
& \text { number of cords/chain }=150 \text { cords/2 chatns } \times 40 \text { resharpening } \\
& =3,000 \text { cords/chain } \\
& \text { total wear }=85 \times 10^{6} \text { cords } \times 1 \text { chain } / 3000 \text { cords } \times 2 \text { Ib/chain } \\
& =28 \text { tons. } \\
& \text { indirect loss }=28 \text { tons } \times 35 \times 10^{6} 8 \mathrm{tw} / \mathrm{ton} \\
& =1 \times 10^{9} \text { Btu. }
\end{aligned}
$$

The chain bar was estimated to weigh 16 pounds for a $49-i n c h$ chain saw. Chatn wear is characterized by wearing of the flange outside of the chain groove. The chain bars are regrooved periodically to improve performance. Assuming the chain bars have 5 times the life of the chains, the total material loss due to chain bar wear can be estimated as follows:

$$
\begin{aligned}
& \text { number of cordstchain bar }=150 \text { cords/2 chains } \times 200 \\
& =15,000 \text { cords/chain bar } \\
& \text { total wear }=85 \times 10^{6} \text { cords } \times 1 \mathrm{bar} / 15,000 \text { cords } \times 16 \text { pound } / \mathrm{bar} \\
& \# 45 \text { tons of stee] } \\
& \text { indirect } 1055=45 \text { tons } \times 35 \times 10^{6} \text { tututon } \\
& =1.6 \times 10^{9} \mathrm{Btu} \text {. }
\end{aligned}
$$

Table 6.11 lists estimates of direct and indirect losses for tree harvesting activities based on 1983 pulpwood production figures. 
TABLE 6.11. Annual Direct and Indirect Losses in Tree Harvesting (Paper Trade Journal 1985)

$\begin{array}{ll}\frac{\text { Process }}{\text { Birect }} & \frac{\text { Total }}{\text { Friction during cutting }} \\ \begin{array}{ll}\text { Indirect } \\ \text { Wear of chain teeth }\end{array} & 4.0 \times 10^{10} \mathrm{Btu} \\ \text { Wear of chain bar } & 1.0 \times 10^{9} \mathrm{Btu} \\ & 1.6 \times 10^{9} \mathrm{Btu}\end{array}$

Pulpwood Debarking

The debarking process takes cut pulpwood and removes bark prior to chipfing or crinding. Although pulp can be made from pulpwood that has not been cebarked, higher quality paper is usually made from debarked wood. Also, Bark is more abrasive than the underlying softwood, and chippers and grinders, which frocess debarked wood, exhibit longer life. (a) The most common methods of debarking logs are barking drums, mechanical debarkers, and hydraulic debarkers. Each of these methods is examined in the following paragraphs.

Barking drums are large rotating conduits that tumble logs together and thus remove the bark. The drums range in diameter from 7 to 16 feet, with 14 feet heing the most common diameter. The most common length is 80 feet. The drums are rotated at 5 to 7 rpm by an electric notor ranging from 400 to $500 \mathrm{hp}$ at: 1750 rpm for the 14-foot diameter, 80-foot long drum.

Wear in the barking drums occurs when grit from the logs being debarked abrades against the drum's internal shell. To protect the shell itself, "lifters" are installed. A steel plate that is $3 / 4$ inch thick, 12 inches wide, and 20 faet long is bent and welded to the steel shell of the drum, Drums tend to require little maintenance, although the drums are refurbished every 3 to 5 years by welding new lifter plates.

The output of the drum debarker is highly seasonal. Softwod output during the surner. 85 debarked, is around $145 \mathrm{cords} / \mathrm{hr}$, while winter output using

\footnotetext{
(a) Obtained through conversation with Mr. Lorne Greenwood, Carthage Machine Company, Carthage, New York.
} 
frozen wood is only 75 cords $/ \mathrm{hr}$, 85\% debarked. Average output is estimated to be 115 cords/hr.

Indirect losses from barking drums result from the wear of lifters. Indirect losses were estimated by assuming that the lifters are replaced after 4 years, for a total metal loss rate of $22 \mathrm{cu} f$ per year. This estimate was made by assuming 18 lifters are positioned around the circumference of a 14-foot diameter drum that is 80 feet long. Because the drum debarker is a high-output device, it was assumed that 85 of the pulpwood consumed was debarked in this way, for a total throughput of $73 \times 10^{6}$ cords/yr. The number of drum debarkers in service was determined by estimating a per-annum service of $2500 \mathrm{hr}$, with an average output of $115 \mathrm{cords} / \mathrm{hr}$. The resulting total indirect loss is $4.8 \times 10^{10}$ gtu/yr.

Mechanical debarking is used in smaller pulp mills and samills. Because the mechanical debarker operates with one stick at a time, the output of the debarker is less than that of the larger drum debarker. The most prevalent design consists af a rotating ring of knives, which peel bark from sections of cut pulpwood as it is drawn through the ring by a set of spiked wheels. This process, known as ring debarking, is essentially an abrasive cutting process, and all direct tribological losses were assumed to be due to friction at the knife-bark interface. Large ring debarkers are capable of handling logs up to 40 inches in diameter, al though smaller log sizes are more prevalent. Indirect losses occur when abrasive cutting elements wear and are replaced. Specifically, losses can be categorized as follows:

- direct tríbological losses

- bearing losses in ring motor

- bearing losses in feedworks motor

- friction losses in debarking

- indirect tribological losses

- wear of knives

- wear of feedwork spires.

Table 6.12 lists typlcal operating specifications for a ring debarker. The cutting ring is driven by a 60-hp electric motor, while the feedworks is 
TABLE 6.12. Typical Specification for Ring Debarker

\begin{tabular}{|c|c|}
\hline Process & Specification \\
\hline Cutting geometry & Radially positioned tungsten carbide knives \\
\hline Cutting ring power & $60 \mathrm{hp}$ \\
\hline Feedworks power & $40 \mathrm{hp}$ \\
\hline Linear throughput & $120 \mathrm{ft} / \mathrm{min}$ \\
\hline
\end{tabular}

driven by a 40-hp motor. Typical linear foot throughput is $120 \mathrm{ft} / \mathrm{min}$. Assuming an average log diameter of 12 inches, this particular ring debarker is capable of debarking about $60 \mathrm{cords} / \mathrm{hr}$. Other estimates have been set at $30 \mathrm{cords} / \mathrm{hr}$ (Merrill 1970).

Assuming that $50 \%$ of the energy is consumed by friction and assuming an average output of $40 \mathrm{cords} / \mathrm{hr}$ and a power usage of $30 \mathrm{hp}$ during debarking, the direct tribological loss in debarking is estimated to be $0.35 \mathrm{hp}$-hr/cord. Assuming $10 \%$ of the pulpwood is debarked using ring debarkers, $7.5 \times 10^{9} \mathrm{Btu} / \mathrm{yr}$ would be expended.

Estimates of indirect tribological losses were made by estimating the amount of cutting head material lost during ring debarking. Rings typically have 24 teeth with carbide inserts brazed onto the knives. The knives with the tungsten carbide inserts typically last between 3 to 4 months of operation, 1 shift per day, before being replaced. (a) With an average of $30 \mathrm{cords} / \mathrm{hr}$, the carbide inserts last about 14,000 cords. Repair to the knives usually involves brazing on new inserts and discarding the old, with a loss of about 20 grams per insert. The total material loss is estimated to be 580 pounds of carbide. Table 6.13 summarizes tribological losses in mechanical debarking.

Hydraulic debarking is a nonabrasive technique in which bark is removed from pulpwood through high-pressure jets, which impinge on the surface of the cut wood. Jets of high-pressure water or steam under pressure (1400 to 1500 psi) are directed through narrow nozzles. Use of this technique is prevalent in the Pacific Northwest where log diameters are too large for drum

(a) Estimates given by Nicholson Manufacturing, Seattle, Washington. 
TABLE 6.13. Direct and Indirect Tribological Losses

in Mechanical Debarking

\begin{tabular}{|c|c|}
\hline Process & Tribological Losses \\
\hline \multicolumn{2}{|l|}{ Direct Losses } \\
\hline $\begin{array}{l}\text { Friction losses during debarking } \\
\text { Indirect Losses }\end{array}$ & $7.5 \times 10^{9} \mathrm{Btu} / \mathrm{yr}$ \\
\hline Wear of cutting elements & $1.5 \times 10^{7} \mathrm{Btu} / \mathrm{yr}$ \\
\hline
\end{tabular}

debarking. This technique requires large amounts of power to drive the highpressure pumps, which must operate continuously whether or not a log is being debarked. Typical turbine or motor size is $1,200 \mathrm{hp}$ at $3,600 \mathrm{rpm}$.

The use of hydraulic debarkers is restricted by its relatively low output compared to drum debarkers and problems in treating the water after use. To reduce pollution of streams with bark pieces, water used in hydraulic debarking must be filtered and separated before being released. In addition, clogging or erosion of the jet nozzles occurs when recycled water is not sufficiently cleaned. The lack of significant tribological sink mechanisms and minimal usage of this debarking technique ( $5 \%$ of debarking) results in insignificant tribological losses for hydraulic debarking.

\section{Pulpwood Chipping}

Debarked pulpwood is either converted to groundwood pulp directly without further processing, or it is converted to wood chips for producing refiner pulpwood or pulp through chemical digestion. Because $80 \%$ of wood pulp is estimated to come from the Kraft process, a considerable quantity of wood chips is produced.

The process of chipping is a combination of abrasive cutting and fracture of the pulpwood. The most common chipper in use is the disc chipper, which uses a series of blades mounted on a rotating disk 8 feet to 12 feet in diameter. Typical capacity for the disc chipper is 120 cords/hr.

The face of the disk has a series of radial knives, which shear the pulpwood as it is fed against the face of the disk. Once formed, the chips move through chip slots in the face of the disk to the reverse side of the disk, 
where they are gravty fed or blown out of the chipper. Because of the harsh conditions inside the chipper, parts are replaced routinely. Table 6.14 shows estimates of repair/replacement frequency for crucial parts of the chipper. The cutting knjues are resharpened after every 8 mour shift, but the blades are finally replaced after about 1000 hours of operation. The disk uses numerous face plates to decrease wear. The shrouding around the disk wears from impact whth flying wood chips and is typically replaced every 2 years. other wear surfaces include the feed-in chute, which is protected by weld deposits of wear-resistant alloys.

Indirect losses during chipping were estimated by assuming that the blades and face plates are totally replaced during service. Each blade weighs about 25 pounds and is replaced twice a year. For a machine with 13 blades, the total material loss per year per machine is about 650 pounds per machine. The face plates are heavier and are replaced with the same frequency, for a materlat lost of $18201 \mathrm{~b} / \mathrm{yr}$. The shroud can be expected to lose about 1000 pounds during 1 year of service.

Table 6.15 summarizes the indirect losses during chipping. Calculations are based on an industry fleet of 280 chippers, which were derived from the 1983 pulpwod production and a capactity of 120 cords/hr.

\section{$6.2,2$ Pulp Production}

Pulp is produced by separating cellulose wood fibers from the connective lignin in the wood. The process is performed chemically through digestion or

TABLE 6.14. Weight, Size and Replacement Frequency for Chipper Components (a)

\begin{tabular}{|c|c|c|}
\hline Pant & Approximate size/ weight & Typical Replacenent \\
\hline 〈nives & 35 in. $\times 6$ in. $\times 1 / 2$ in. & $1000 \mathrm{hr}$ \\
\hline ship slats & Not avallable & $500 \mathrm{hr}$ \\
\hline Jisk face plates & 70 ib each & $1000 \mathrm{nr}$ \\
\hline shrouding & 200010 & $4000 \mathrm{mr}$ \\
\hline
\end{tabular}

(a) Information obtained from a conversation with Mr. Lorne Greenwood, Carthage Machine Conpany. Carthage, New York. 
TABLE 6.15. Indirect Losses in Chipping

\begin{tabular}{lcc} 
& $\begin{array}{c}\text { Weight Loss Per } \\
\text { Machine Per Year (10) }\end{array}$ & $\begin{array}{c}\text { Energy } \\
\text { Loss }\left(10^{9} \text { Btu }\right)\end{array}$ \\
\cline { 2 - 3 } Blade wear & 650 & 3.2 \\
Face plate wear & 1820 & 8.9 \\
Shrouding & 1000 & 4.9
\end{tabular}

nechanicaily through further grinding of chips or solid pulpwood. The following techniques of forming pulp were examined: kraft pulpmaking, groundwood pulp, and pulp from recycled secondary fiber.

Kraft Pulpmaking

Kraft pulpmaking is a chemical process in which little abrasive or shaking wear occurs. Slight corrosion problems may occur due to the severity of the chemical stack. Most direct tribological losses can be traced to pumping losses during pulp processing. These losses were not tabulated during this study.

Groundwood Pulp.

Groundwood pulp refers to putp produced frem debarked pulpwood or chips by mechanical grinding. Groundwod pulp produced cirectly fron debarked pulpwood is referred to as stone groundwood because of a large abrastve grinding stone that produces fibrous pulp. Groundwood pulp preduced directly from chipped pulpwood is referred to as chip groundwood. Chips used to produce chip groundwood are sometimes preneated with process stean to reduce the energy required for further grinding. Both processes will be reviewed separately.

Stone Groundwood.

Stone groundwood is produced directly from debarked pulpwood by loading the pulpwood against a large rotating grinding stone. Grindstones typically measure 67 inches in diameter and range from 54 to 69 inches wide to accomalodate 4- or 5-foot lengths of cut pulpwood. Surtace speed at the cutting edge is typically around $10,000 \mathrm{ft} / \mathrm{min}$, which transiates into a rotational speed of $570 \mathrm{rem}$.

The tajor energy expenditure in stone groundwood pulp is the power used to rotate the grinding wheel. Electric motors ranging from 3,000 to 10,000 hp are 
used; that typical size is 6,500 ho. (a) For this power expenditure, roughly 50 to 70 tons of pulpwood are produced per day. Approximately go stone groundwood pulpers are in use in the Inited states today.

Becatuse the process relies on abrasive cutting of wood, direct friction losses occur at the stone-pulpwood interface. Loading of pulpwood against the grinding stone is usually regulated so that the full ayalable power is used (Pery 1970). The following formula for grinding can be used to obtain effichent grinding conditions:

$$
\text { Power }=A \times \vee \times P \times F
$$

where $A=$ grịnding area

$V$ = peripheral speed of pulpstone

P grinding pressure

$F=$ friction coefficient.

Assuming that $98 \%$ of the motor horsepower is used in the grinding process and assuriting an average capacity of 60 tons/day, the average energy used to produce a ton of pulp at one grinder is $106 \mathrm{hpmay/ton.} \mathrm{This} \mathrm{translates} \mathrm{to}$ $2.2 \times 10^{6}$ 8tu per ton of pulpwood, other estimates have been set at $4.5 \times 10^{6}$ Etu per ton for stone groundwood. (b) Estinates given by one manufacturer of grinding stones set the energy expenditure somewhat lower, between $1 . z$ and $1.8 \times 10^{6} \mathrm{Btu} / \mathrm{ton}$ (a) An average energy expenditure would be around $2 \times 10^{6}$ etu/ton of pulp produced. Assuming that $10 \%$ of this is due to recoverable friction losses, the direct tribological energy cost is $0.2 \times 10^{6} \mathrm{Btu}$ per ton of pulp produced.

Indirect losses were estimated by calculating the anount of grinding wheel lost during pulp generation. Pulpwood stones (pulpstones) are made by forming grinding wheel material around ateel shel1. The tnitial material thickness is around 5 inches, and the wheel is used until half of the material has worn away. Assuming an initial wheel diameter of 67 inches and a width of 54 inches,

(a) Estinates given by the Norton Company, Worcester, Massachusetts.

(b) Information provided by CE/Baver Company, Springfield, ohio. 
this represents a material loss of $15.8 \mathrm{cu} \mathrm{ft}$ per wheel. Depending upon the nature of the cut pulpwood, these stones must be replaced every 1 to 4 years. (a) Using an average life of 2-1/2 years, this represents a material loss of $6.3 \mathrm{cu}$ ft per year per stone. Because about 90 grinders operate in the United States, the total yearly material loss is estimated to be $570 \mathrm{cu} f t$ of abrasive wheel material. Direct and indirect losses are summarized in Table 6.16.

Chip Groundwood

Chip groundwood, sometimes referred to as lefiner groundwood, is produced from already chipped pulpwood. The technique involves grinding uniform chips between two rotating disks, followed by a centrifugal separation of fibers. Prior to grinding, the wood chips are usually treated with process steam to soften the wood and reduce grinding time and energy. Chips are frequently washed prior to grinding to remove abrasive grit.

The refiner is sized according to disk diameter and motor horsepower; the typical size is a 56-inch diameter, 10,000 hp unit. (b) For pulp processing, the two disks are forced together by hydraulic bylinders and kept out of mutual contact by the chip feedstock. Chips of unifom size are introduced via screw feed at a continuous rate.

The grinding surfaces of the two disks are made from a chromium-molybdenum alloy (white cast iron), which exhibits an as-cast hardness of 55 Rc. Recent new heat treatments have succeeded in increasing this hardness to $60 \mathrm{Rc}$ with an accompanied increase in wear resistance. As-cast disks last between 500 and

TABLE 6.16. Direct and Indirect Losses of Stone Groundwood Pulp Production

\begin{tabular}{|c|c|}
\hline Process & Tribological Losse \\
\hline \multicolumn{2}{|l|}{ Direct Loss } \\
\hline Friction during cutting & $3.9 \times 10^{11} \mathrm{Btu} / \mathrm{yr}$ \\
\hline Indi rect Loss & \\
\hline Loss of grinding wheel material & $1 \times 10^{10} \mathrm{Btu} / \mathrm{yr}$ \\
\hline
\end{tabular}

(a) Estimates given by the Norton Company, Worcester, Massachusetts.

(b) Information provided by CE/Bauer Company, Springfield, Ohio. 
750 hours before the grinding surfaces of the disk have to be replaced. New riardened surfaces reportedly last up to 1000 hours. (a)

The grinding surface of the disks consists of a series of radial ridges $1 / 8$ of ar inch high. Wood fiber bundles are sheared between two ridges on the cpposing disk surfaces. The surfaces are effective in producing pulp until the ridges become worn down. After wear, the surface segments that form the ridged surface are unbolted from the body of the disk and replaced with new segments.

As in the analysis of other similar equipment, a recoverable friction compronent of $10 \%$ was applied to the energy requirements of the disk refiners to estimate their direct tribological loss. Because this is a mechanical process similar to stone groundwood pulping, energy levels of both stone groundwood and refiner clroundwood are expected to be similar. Large refiners operate at energy levels of 100 to $120 \mathrm{hp}$-day/ton. Assuming an annual production of $2930 \times 10^{3}$ tons, this translates into $0.58 \times 10^{12}$ Btu loss total per year for refiner-froduced groundwood.

Indirect losses were estimated by observing that the ridged surface segments of the two disks are replaced entirely after the ridges on the surface are worn. The surface segments collectively resemble a donut-shaped section of l-inch trick material measuring 56 inches in total diameter, with an inner hub ciameter of 36 inches. This leaves a grinding surface area of 10 square feet. Fieplacing both disks represents a loss of 1.7 cubic feet of material. Disks cre assumed to be replaced 4 times a year, for an estimated material loss per machine cif 1.7 tons.

The number of refiners in service was calculated by using an estimated cutput of 120 tons per day per machine. Assuming 250 working days per year, each refiner supplies 30,000 tons each year. With total estimated production figures cf $2930 \times 10^{3}$ tons, this translates into about 100 operating units in the United States.

The number of disk refiners now in use exceeds 100 , although many of the units are used as secondary refiners for chemical digesters to aid in further

(a) Infcrmation provided by CE/Bauer Company, Springfield, Ohio. 
refining that is pulp already digested. In these units, energy expenditure component wear is far less than for units that produce mechanically generated pulp alone. Therefore, the estimate of 100 units that produce mechanically generated pulp is believed to be an accurate estimate.

Indirect losses from wear were estimated by multiplying the estimated-permachine loss of 1.7 tons of material by the number of units, giving a total material loss of 170 tons per year. Indirect and direct losses for chip groundwood are summarized in Table 6.17 .

\section{Secondary Fiber}

As the cost of woodpulp increases, the use of pulp manufactured from secondary fiber also increases. Approximately $20 \%$ of paper products are now made from recycled secondary fiber, for an approximate yearly output of $15 \times 10^{6}$ tons. Sources of secondary fiber include newsprint and paperboard with a variety of inks and paper finishes on the surface. The process of producing pulp from this fiber consists of the following steps: (1) pulping or defibering, (2) cleaning and screening, (3) washing out contaminants, (4) dewatering and thickening, (5) bleaching, and (6) bleach washing and thickening. (a) of these six processes, the last five are mostly chemical bleaching and washing processes having very little tribological loss. The first process--pulping or defibering--involves the chopping and mulling of solid waste paper into digestible pieces of paper fiber. Because this process involves energy expenditure

\begin{tabular}{|c|c|}
\hline Process & Tribological Losses \\
\hline \multicolumn{2}{|l|}{ Direct Loss } \\
\hline Friction during pulping & $5.8 \times 10^{11} \mathrm{Btu} / \mathrm{yr}$ \\
\hline \multicolumn{2}{|l|}{ Indirect Loss } \\
\hline $\begin{array}{l}\text { Replacement of disk-grinding } \\
\text { plates }\end{array}$ & $8.5 \times 10^{9} \mathrm{Btu} / \mathrm{yr}$ \\
\hline
\end{tabular}

(a) Information provided by Black-Clawson Company, Middletown, Ohio. 
during chopping, plus considerable indirect losses due to mechanical wear, it was examined for direct and indirect tribological losses.

In the initial stage of defibering, raw stock is fed directly into a large cylindrical vessel fitted with a series of rotary vanes that shear and mulch the waste: paper. One representative design uses a large cylindrical vessel with a fluted bottom to direct waste paper to the bottom. At the bottom of the vessel, a series of rotating vanes or blades 6 feet in diameter rotate at a top speed of between 3,400 and $4,000 \mathrm{ft} / \mathrm{min}$. The secondary pulp is filtered through sicreens in the vessel bottom and sides and recirculates for more defibering. Horsepower requirements for this vessel range between 250 and $500 \mathrm{hp}$, with $400 \mathrm{hp}$ being an average value. Output ranges from 350 to 500 tons/day, depending on the base stock composition. The process mix is heavily watered to facilitate mixing and agitation of the slurry.

Ind rect losses due to wear of the blades are controlled by using Stellite hard fac'ngs that are strip-cladded to the blades at a thickness of $3 / 16$ inch. Wear of these blades is extremely variable, with replacement of the hard facing performed every 1 to 5 years, depending on the nature of the feedstock. (a) Assuming reasonable care, new hard facing is probably applied every other year at scheduled downtimes for plant maintenance. Assuming a total blade surface area of about 12 square feet (each blade measures 1-1/2 $\times 1 \mathrm{ft}$ ) and a strip clad thickness of $3 / 16$ inch, the material volume loss due to wear is estimated t:o be $16 \% \mathrm{cu}$ in. per year per machine. Because the density of Stellite is around $0.3 \mathrm{lb} / \mathrm{in} .{ }^{3}$, this translates into a weight loss of 48 pounds per year per mach'ne.

The number of hydropulpers in service was estimated by assuming an output of 400 tons of pulp per day per machine, with 250 possible working days. This t:ranslates into 100,000 tons produced per machine every year. To produce $15 \times$ $0^{6}$ tons of paper product from secondary pulp, approximately 150 hydropulpers would be required, which would produce a total weight loss of 3.6 tons per year.

Direct losses due to process friction during defibering were estimated by examining the motor power levels during fiber agitation. With an average motor

(a) Information provided by Black-Clawson Company, Middletown, Ohio. 
size of $400 \mathrm{hp}$ and a production rate of 400 tons of pulp per day, the amount of energy used to cut and mix the waste paper is about $15 \times 10^{3}$ Btu/ton of pulp produced, assuming 25 of the avallable power is used to overcome friction. This translates to direct 10 sses of $2.3 \times 10^{11}$ stu/yr. Table 6.18 summarizes direct and indirect tribological losses for secondary defibering.

\subsection{SUMMARY OF TRIBOLOGICAL EMERGY LOSSES IN PIJLP ANO PAPER}

Tables $6.19,6.20$, and 6.21 summarize the tribological energy losses associated with the principal pulp and paper operational activities. The generic

TABLE 6.1A. Direct and Indirect Losses During Secondary Defibering

$\begin{array}{ll}\frac{\text { Process }}{\text { Direct Loss }} & \text { Tribological Losses } \\ \begin{array}{l}\text { Loss due to cutting } \\ \frac{\text { Indirect Loss }}{\text { Blade wear due to friction }}\end{array} & 2.3 \times 10^{11} \mathrm{Btu} / \mathrm{yr} \\ & 1.8 \times 10^{8} \mathrm{Btu} / \mathrm{yr}\end{array}$

TAB1.E 6.19. Generic Tribological Loss Mechanisms in Pulp and Paper

\begin{tabular}{|c|c|c|c|c|}
\hline \multirow{2}{*}{$\begin{array}{c}\text { Operationd } \\
\text { Activity }\end{array}$} & \multicolumn{4}{|c|}{ Generic Tribological Mechanisf } \\
\hline & (1) & $(2)^{-1}$ & $(3)$ & (4) \\
\hline \multicolumn{5}{|l|}{ Wood Preparation } \\
\hline Tree harvesting & $x$ & & & \\
\hline Pulpwood Debarking & $x$ & & $x$ & $x$ \\
\hline Pulpwood Chipping & 美 & & & \\
\hline \multicolumn{5}{|l|}{ Pulping } \\
\hline Stone Groundwood & $x$ & $\mathrm{x}$ & & \\
\hline Chip Groundwood & $x$ & $x$ & & \\
\hline Hydropu?ping & $x$ & & & $x$ \\
\hline $\begin{array}{l}\text { (1) Abrasion. } \\
\text { (2) Adhesion. } \\
\text { (3) Corrosion. } \\
\text { (4) Erosion. }\end{array}$ & & & & \\
\hline
\end{tabular}


TABLE 6.20. Annual Direct Tribological Energy Losses in Pulp and Paper

\begin{tabular}{|c|c|c|c|}
\hline $\begin{array}{l}\text { Operationa! } \\
\text { Activity }\end{array}$ & $\begin{array}{l}\text { Principal Energy } \\
\text { Form Consumed }\end{array}$ & Energy Loss Rate & $\begin{array}{c}\text { Total } \\
\text { Energy Loss } \\
\left(10^{\circ} \text { Btu }\right)\end{array}$ \\
\hline \multicolumn{4}{|l|}{ Hood Preparation } \\
\hline Tree Harvesting & Gasoline & $480 B t u / \operatorname{cord}$ & 40 \\
\hline Pulpwood Detarking & Electric & 890 Btu/cord & 7.5 \\
\hline Pulpwood Chipping & $-\cdots$ & -- & - \\
\hline \multicolumn{4}{|l|}{ eulping } \\
\hline Stone Groundwood & Electric & $0.2 \times 10^{6}$ Btu/ton pulped & 390 \\
\hline Chip Groundwood & Electric & $0.2 \times 10^{6} \mathrm{Btu} /$ ton pulped & 580 \\
\hline Hydropulping & Electric & $15 \times 10^{3}$ Btu/ton pulped & 230 \\
\hline & & & 1247.5 \\
\hline
\end{tabular}

TABLE 6.21. Annual Indirect Tribological Energy Losses in Pulp and Paper

\begin{tabular}{|c|c|c|c|}
\hline $\begin{array}{l}\text { Operational } \\
\text { Activity }\end{array}$ & $\begin{array}{c}\text { Faterial Type } \\
\text { Worn }\end{array}$ & $\begin{array}{c}\text { Material wear } \\
\text { Rate } \\
\end{array}$ & $\begin{array}{l}\text { Total Energy } \\
\text { Loss }\left(10^{9} \text { Btu }\right)\end{array}$ \\
\hline \multicolumn{4}{|l|}{ Wood Preparation } \\
\hline Tree Harvesting & Steel & $1.71 \mathrm{~b} / 1000$ cords & 2.6 \\
\hline Pulpwood Debarking & Steel & $38 \mathrm{ib} / 1000 \mathrm{cords}$ & 48 \\
\hline Pulpwood chipping & Steel alloys & $11 \mathrm{lb} / 1000 \mathrm{cords}$ & 17 \\
\hline \multicolumn{4}{|l|}{ Fulping } \\
\hline Stone troundwood & Grinding stone & $0.29 \mathrm{ft}^{3} / 1000$ ton pulped & 10 \\
\hline Chip Groundwood & Gr-Mo alioy & $116 \mathrm{ib} / 1000$ ton puiped & 8.5 \\
\hline Hydropulping & Steel & $0.48 \mathrm{~Tb} / 1000$ ton pulped & 0.18 \\
\hline & & & 86.28 \\
\hline \multicolumn{4}{|c|}{$\begin{array}{l}\text { tribological mechanisms contributing to energy losses for each operational } \\
\text { activity are identified in Table } 6.19 \text {. Additional information concerning the } \\
\text { rrincipal energy form consumed by an operation, the energy loss rate, material } \\
\text { type worm, and material wear rate is also provided in Tables } 6.20 \text { and } 6.21 \text {. } \\
\text { Abrasion was identified most often as a tribological loss mechanism for } \\
\text { fulp and paper operational activities-abrasion was cited as a loss nechanism } \\
\text { for each of the activities examined in detail, other loss mechanisms noted } \\
\text { were adhesions, corrosion, and erosion. Although the information in Table } 6.19\end{array}$} \\
\hline
\end{tabular}


is more qualitative than quantitative (i.e., the most commonly occurring loss mechanisms may not be the cause of the largest energy losses), it does indicate tribological mechanisms that are likely to be significant in the pulp and paper industry.

Direct losses were estimated to be more thân an order of magnitude greater than indirect losses. Direct tribological losses are associated with the energy to overcome friction between two surfaces. Direct energy loss activities in pulp and paper are largely powered by filectricity. The principal tribological energy loss activities are mechanical pulping of chips and logs and hydropulping of recycled paper.

Indirect tribological losses are associated with the wearing out of equipment and the material that is physically worn away. The principal indirect loss items in pulp and paper are associated with drum debarkers, chippers, and mechanical pulpers. Steel and steel alloys are the most common materials being worn. A significant amount of wear also occurs in the grinding stones used for stone-groundwood pulping.

\subsection{REFERENCES}

American Paper Institute. 1971. Wood Pulp Statistics, 35th edition, American Paper Institute, New York, New York.

Chiogioji, M. H. 1979. "The Pulp and Paper Industry." In Industrial Energy Conservation. Marcel Dekker, Inc., New York, New York.

Griffin, E. A., et al. 1984. Cogeneration Handbook for the Pulp and Paper Industry. PNL-4852, Pacific Northwest Laboratory, Richland, Washington.

Merrill, A. A. 1970. "Pulpwood Handling." Handbook of Pulp and Paper Technology. K. W. Britt, ed., Van Nostrand Reinhold Company, New York, New Yök.

Paper Trade Journal. 1985. Lockwood's Directory. Vance Publishing Corporation, New York, New York.

Perry, J. H. 1970. "Groundwood-Stone." In Handbook of Pulp and Paper Technology. Van Nostrand Reinhold Company, New York, New York.

U.S. Census Bureau. 1983. 1982 Census of Manuactures. U.S. Census Bureau, Washington, D.C.

Zobel, B. 1970. "Pulpwood Measuration." In Handbook of Pulp and Paper Technology. K. W. Britt, ed., Van Nostrand Reinhold Company, New York, New York. 


\subsection{FOOD PROCESSING}

This chapter identifies and characterizes total energy use and tribological losses in the food processing industry. Energy consumption is specified by fuel type for the industry as a whole, and total energy consumption is identified for each of the nine 3-digit SIC (Standard Industrial Classification) subsets of the industry and the top 10 energy-consuming 4-digit SIC industries. The major processes and products of the food processing industry are briefly described, and those processes identified as having significant tribological losses are reviewed and described in more detail. The nature of each tribological sink and the mechanisms leading to direct and/or indirect losses are :hen characterized. Finally, the estimates of energy losses and the calcula:ional approach taken are identified. The tribological losses estimated for rood processing are summarized at the end of the chapter.

\subsection{INTRODUCTIDN}

The food processing industry includes businesses engaged in the processing of raw agricultural inputs into packaged food products as their primary activity. The major subdivisions of food processing are meat products (SIC 201), dairy products (SIC 202), preserved fruits and vegetables (SIC 203), grain mill products (SIC 204), bakery products (SIC 205), sugar and confectionery products iSIC 2061, fats and oils (SIC 207), beverages (SIC 208), and miscellaneous "oods (S:C 209). Each of these subdivisions is broken into individual product categories such as meat packing plants, fluid milk, wet corn milling, and malt beverages. Food processing involves a wide array of activities that include pressing. trimming, peeling, blending, screening, milling, washing, conveying, and packaging.

\subsection{Energy Consumption in Food Processing}

Total energy consumption in food processing was about 0.9 quad in 1981 , according to data presented in the 1982 Census of Manufactures (U.S. Bureau of Census 1983). (As of May 1984, the 1981 data are the latest comprehensive energy consumption information available from the U.S. Census Bureau.) Energy consumption is specified by fuel type for the industry as a whole in Table 7.1. 
TABLE 7.1. Energy Consumption by Fuel Type in the Food Processing Industry (1981)

\begin{tabular}{lrr}
\multicolumn{1}{c}{ Fuel } & $\frac{10^{12} \mathrm{Bt}}{148.5}$ & of Total \\
\cline { 1 - 2 } Electricity & 24.7 & 16.3 \\
Distillate & 60.4 & 2.7 \\
Residual & 119.0 & 6.6 \\
Coal & 1.7 & 13.0 \\
Coke & 471.0 & 0.2 \\
Natural Gas & 6.6 & 51.6 \\
Liquid Petroleur Gas & 81.3 & 0.7 \\
Other & 913.2 & 8.9 \\
& & 100.0
\end{tabular}

Natural gas is the predominant fuel in the food industry, providing over $50 \%$ of the energy requirement. Electricity, coal, and fuel oil are the three next most common energy forms in order of consumption. Most of the fossil fuels are used to provide process heat and some space heating, refrigeration, and electric generation. Electric energy is used to operate a wide variety of mechanical activities.

Energy consumption is spread fairly evenly among the nine 3-digit SIC subsets of the food industry (see Table 7.2). No single group represents an exceptionally large or small portion of total consumption. Energy consumption at the 4-digit SIC industry level is similarly cistributed (see Table 7.3). Wet corn milling, the largest energy consumer the the 4mdigit level, accounts for only 10 of the food industry total; the top ten 4-digit industries together represent $54 \%$ of food industry erergy consumption.

The energy consumption data presented above and in the following tables in this chapter were obtained from the 1982 Census of Manufactures - Fuels and Electric Energy Consumed (Bureau of Census 1983). The data are for consumption of purchased fuels and electric energy by manufacturing establishments for producing heat and power. These figures do not include energy forms produced and consumed at the same establishment, such as coke oven gas, blast furnace gas, still gas, petroleum coke, etc. However, little fuel is produced and consumed 
TABLE 7.2. Energy Consumption Within the Major Food Processing Industry Subgroups (1981)

\begin{tabular}{|c|c|c|c|}
\hline SIC \# & Classification Name & $10^{12}$ Btu & $\%$ of Total \\
\hline 201 & Meat Products & 103.4 & 11.3 \\
\hline 202 & Dairy Products & 87.3 & 9.6 \\
\hline 203 & Preserved Fruits and Vegetables & 113.6 & 12.4 \\
\hline 204 & Grain Mill Products & 153.3 & 16.8 \\
\hline 205 & Bakery Products & 50.2 & 5.5 \\
\hline 206 & Sugar and Confectionery Products & 127.8 & 14.0 \\
\hline 207 & Fats and $0 \mathrm{ils}$ & 109.1 & 11.9 \\
\hline 208 & Beverages & 111.9 & 12.3 \\
\hline \multirow[t]{2}{*}{209} & Miscellaneous Foods and Kindred Products & $\underline{56.4}$ & 6.2 \\
\hline & & 913.0 & 100.0 \\
\hline
\end{tabular}

TABLE: 7.3. Top Ten Energy-Consuming Food Processing Industries at the 4-0igit SIC Level (1981)

\begin{tabular}{|c|c|c|c|}
\hline SIC \# & Classification Name & $10^{12} \mathrm{Btu}$ & $\begin{array}{l}\% \text { of Total } \\
\text { Food Industry }\end{array}$ \\
\hline 2011 & Meat Packing Plants & 61.4 & 6.7 \\
\hline 2026 & Fluid Milx & 31.1 & 3.4 \\
\hline 2033 & Canned Fruits and Vegetables & 42.9 & 4.7 \\
\hline 2038 & Frozen Fruits and Vegetables & 30.2 & 3.3 \\
\hline 2046 & Wet Corn Milling & 92.4 & 10.1 \\
\hline 2051 & Bread, Caxe, and Related Products & 38.8 & 4.2 \\
\hline 2062 & Cane Sugar Refining & 29.9 & 3.3 \\
\hline 2063 & Beet Sugar & 72.2 & 7.9 \\
\hline 2075 & Soybean $0 i l$ Mills & 44.9 & 4.9 \\
\hline 2082 & Malt Beverages & 53.1 & 5.8 \\
\hline & & 496.9 & 54.3 \\
\hline
\end{tabular}

within the food processing industry, so purchased fuels should be a close approximation of total energy consumption.

The food processing industry produces thousands of individual products to suit the tastes of consumers. In contrast to other industries, such as primary 
metals, where single homogeneous product can often be associated with a 4-dight industry, 4-digit food processing industries may have hundreds of prom duct forms (e.g., canned fruits and vegetables). Because of the large number of individual product forms, energy analyses usually focus at the 4mdigit SIC classification and at an associated generic processing plant representative of al) product forms within that classificaton. In lieu of trying to list the "principal" individual products of the food prosessing industry, Table 1.4 lists all of the 4 -digit suc groups.

TABLE 7.4. Major Product classes within the Food Processing Industry

Meat Packing plants

Sausages and other Prepared Meats

Poultry Dressing Plants

Poultry and Egg Processing

Creamery Butter

Cheese, Natural and Processed

Condensed and Evaporated Milk

Ice Crean and Frozen Desserts

Fluid Milk

Canned specialities

Canned Fruts and Vegetables

Dehydrated Fruits, Vegetables, and Soups

pickles, Sauces, and Salad Dressings

Frozen Fruits and Vegetables

Frozen specialties

Flour and other Grain Mill Products

Cereal breakfast Foods

Rice Milung

Blended and prepared Flout

Wet Corn Milling

Dog, Cat, and Other Pet food

other prepared Feeds

Bread, cake, and Related Products

Cookies and Crackers
Raw Cane Sugar

Cane: Sugar Refining

Beet: Sugar

Confectionery products

chotolate and cocoa products

chewing Gum

Cottonseed Oil Mills

Soybean ofl Mills

other vegetable ofl Mills

Anind and Marine Fats and oils

Shortening and cooking otls

Mal: Beverages

Halt:

Wines, Brandy, and Brandy Spirits

Distilled Liquor, except Brandy

Botlled and Canned Soft Drinks

Other Flavoring Extracts and Syrups

Canted and cured seafoods

Fresh or Frozen Packaged Fish

Roasted coffee

Manufactured Ice

Macaroni and Spaghetti

other Food preparations 


\subsection{FOOD PROCESSING OPERATIDNAL ACTIVITIES}

The numerous products and production pathways of the food processing industry make it difficult to generalize about the operational activities. Each of the thousands of products tends to have unique processing requirements. Nevertheless, several generic operations that occur with some regularity among the many product classes can be identified.

Upon entering the plant, the raw agricultural material is typically cleaned first. Cleaning or washing may also occur at intermediate locations within the process. Several different size reduction operations may be used as preparatory steps for mixing, heating, and chilling. Various separating procedures are used first to break the raw material into components and later to extract the final product before packaging and storage. Separation can be achieved by either mechanical, thermal, or chemical means. A more detailed listing of specific operational activities is presented in Table 7.5 for heating, size reduction, and mechanical, thermal, and chemical separations.

\subsubsection{Analytical Approach}

The food processing industry was initially examined at the 4-digit SIC level (see Table 7.4) to determine which operations should be evaluated further for tribological losses. Size reduction and material conveyance are two generic activities common to most food processing processes that were

\section{TABLE 7.5. Food Processing Operational Activities}

Generic Operation

Mechanical Separation

Thermal Separation

Chemical Separation

Size Reduction

Heating
Specific Operations

Pressing, trimming, stripping, settling, filtering, inspecting/grading, peeling, pulping, screening, centrifuging

Drying, evaporating, roasting, crystallizing

Ion exchange, liming, extracting, stripping

Grinding, slicing, cutting, crushing, shredding, scalping, scaling

Curing, smoking, cooking, pasteurizing, scalding, blanching, baking, brewing, sterilizing 
identified as having significant tribological losses. Size reduction operations (e.g., cutting, shredding, grinding) typically result in erosion and abrasion of knives, rollers, bars, hammers, and similar equipment. Frictional losses in conveying are associated with the wear of bearings, belts, pump impellers, conveyor screws, and other related parts. Both of these processes are chiefly powered by electricity; therefore, the tribological energy losses would be a fraction of the electricity consumption figure identified in Table 7.1 .

Because the food processing industry is diverse, unit operations had to be evaluated collectively rather than individually. Conveying processes are amenable to an aggregate level analysis and will be discussed in detail in Section 7.3. Size reduction operations, while important tribologically, are more process-specific and not as easily evaluated generically. Tribological evaluations of size reduction and mixing equipment are presented in Section 7.4 .

\subsection{TRIBOLOGICAL LOSSES IN FOOD PROCESSING CONVEYING SYSTEMS}

Transportation within the food processing olant represents a major source of tribological losses. This section analyzes direct and indirect tribological losses associated with conveyors and other transportation mechanisms. For the principal loss mechanisms, equipment design and operation are described and the tribological energy losses are estimated.

\subsubsection{Direct Tribological Losses Associated with Conveyors}

Direct tribological loss estimates for conveyor systems are based on an analysis of information presented in Casper (1977) and estimates of sizes, efficiences, and other operating characteristics. The types of conveyors included in the estimates are 1) unit conveyors where the product is supported on rollers, 2) belt conveyors where the belts are supported on rollers, and 3) screw conveyors. The total estimated direct tribological loss is $5.21 \times$ $10^{11} \mathrm{Btu}$, which represents $0.06 \%$ of total energy consumption and $0.35 \%$ of electric energy consumption in the food industry. The major portion (greater than $2 \times 10^{10}$ Btu per group) of the tribological energy loss is associated with the 
industries listed in Table 7.6. These industries have an obvious common factor: they all involve the handling of many individual units such as cans, bottles, or boxes.

\section{i.3.2 Indirect Tribological Losses in Conveying Systems}

Indirect tribological losses are associated with wear mechanisms, which are charcteristic of individual types of equipment used to move materials around the processing plant. The characteristics of various material-moving mechanisns are discussed below to highlight the tribological losses.

\section{Screw Conveyors}

The screw conveyor is usually a long-pitch, plate-steel helix mounted on a shaft sufported by bearings within a U-shaped trough. As the screw rotates, the material fed to it is moved forward by the thrust of the lower part of the helix anc is discharged through openings in the trough bottom, usually at the e!nd.

The steel helicoid is cold rolled in one continuous strip. The cold rolling provides a tapered section with greatest thickness at the shaft and a thin edge with a hardness greater than the original strip. If contact with the steel screw affects food products, then stainless steel, bronze, aluminum, or Monel metal may be used. For abrasive products, the helix may be cast-iron

\section{TABLE 7.6. Estimated Direct Tribological Losses from Conveyors} in Selected Food Industries

\begin{tabular}{lll} 
SIC \# & \multicolumn{1}{c}{ Industry } & Tribological Loss \\
\cline { 2 - 3 } 2033 & Canned Fruits and Vegetables & $1.08 \times 10^{11} \mathrm{Btu}$ \\
2038 & Frozen Fruits and Vegetables & $4.78 \times 10^{10} \mathrm{Btu}$ \\
2032 & Canned Specialty & $4.63 \times 10^{10} \mathrm{Btu}$ \\
2026 & Fluid Milk & $3.29 \times 10^{10} \mathrm{Btu}$ \\
2011 & Meat Packing & $2.79 \times 10^{10} \mathrm{Btu}$ \\
2077 & Animal and Marine Fats and 0ils & $2.78 \times 10^{10} \mathrm{Btu}$ \\
2082 & Malt Beverage & $2.62 \times 10^{10} \mathrm{Btu}$ \\
2038 & Frozen Specialty & $2.35 \times 10^{10} \mathrm{Btu}$ \\
2086 & Soft Drink & $2.15 \times 10^{10} \mathrm{Btu}$
\end{tabular}


sections bolted to the shatt. For sticky materials, a ribbon hellx may be used to prevent buldup along the in between the helix and the shaft.

B thrust bearing is located at the input end of the conveyor. For free flowing, nonabrasive materials, the trough may be deeply filled and the rotating speed may be higher than for heavier, more abrasive materials. The length of the individual screw conveyor is limited by the torque capactity of the center shatt or pipe. When the material is to be noved a distance greater than is possible with a single screw, the individual units are comected in series, one unt feeding the next. Most abrasive materials are handled at lower crosssectional loads than nonabrasive materials to attain maximum economical life of the conveyor and its parts. For abrasive materials, hard surface flighting is added generally just near the outer portion of the work surface.

The bearings at the end of the screw are oxtside the trough. Sealed ball bearings are generally used, with a thrust bearing at the one end. Hanger bearings within the trough in the food industry are generally unlubricated plastic sleeve bearings. For materials that aris sensitive to smali changes in temperature, heat from friction in a hanger bearing may be a problem.

The life of a screw conveyor is a function of the service lt receives. A grain ager generally has a life of 3 to 5 years, where the usage may be 24 hours a day during peak season and 16 hours week during off season. Because of coating wh plastics, troughs are much less subject to wear than they used to be. To date, coating the augers has not been very successul, however. The average life of an auger used with abrasive materiais may be less than 1 year. In such environments hard steel and high-quality sealed bearings are used.

In the food industries, using screw conveyors for materials containing olls (e.9., peanut butter) results in minimal indirect tribological losses. The dimenstons of the trough and the auger are sized to insure there is no contact, and the oil in the material itself profides a lubricant for the bearing surfaces. 

sealed bearings at elther end. One manufacturer of medium-duty conveyors for the food industry stated that the average life of a roller conveyor is 5 to 10 years, based on a 10-hour day. The bearings are replaced every 5 years.

The wear of the bearings is due mainly to kurning of the roller and is little affected by the loading of the product passing over every 5 to 10 seconds. Based on the above manufacturer's portion of the medium-duty conyeyor market in the food industry, 3.6 million bearings are replaced edch year with an average weight of 3 ounces, or 680,000 pound of metal per year. This is equivalent to an indirect energy loss of $1.2 \times 10^{10} \mathrm{Btu} /$ year.

Pallet chain conveyors in the food industry are used to convey beer bottles to the fllling station or other small pans and trays that rest on a surface beneath the iten. plastic chain links and carrier parts have reduced tribological energy losses greatly in the past decade.

Bele conveyors for unt loads are simllar po standard tlat belt conveyors except for their closely spaced idler rollers. The friction factor for rollersupported belts is $3 \%$ to 5 for canvas and rubber belts. For steel wupported belts, the friction factor is $20 \%$ for both belt types. For hardwood-supported belts, the friction factor is $25 \%$ for canvas belts and $30 \%$ for rubber belts.

Monorail or overhead trams take many forms. The iten is supported from or hung fram two or more whels on the monorail. The units may be self-powered, free rolling, or pulled by an adjacent chain. Light-duty underhung cranes also fall in the same category.

The life of an underhung crane is 8 to 9 yads of normal use. The single and double bal1 bearings used in the wheel to support the crane land similarly monorall conveyors) have a life of 2 to 10 years, depending upon usage (average about 6 years). The wearing items on these crancs are the wheels themselves. Both wheels and bearings are replaced at the same tine. One company, which commands $10 \%$ of the underhung crane bustness, raplaces 2000 forged steel wheels per year at 3 pounds per whee?. This is three tons of steel per year. Assuming that there are 4 times as many monorail conveyors in the food industry as there are undertrung cranes, the total amount of metal replaced per year for 
both monorail conveyors and underhung cranes is 150 tons. This represents an indirect $10 \mathrm{ss}$ of $5.25 \times 10^{5} \mathrm{Btu} /$ year.

Pumps

Punps used in the food industries have the critical design constrint of avoiding contamination of the food product. Less viscous fluids are conveyed with centrifugal pumps. Wiscous products may be pumped with augers (such as [eanut butter as nentioned above) or a mono pump. No external lubricants are used becuse of the potential of contaminating the food product being pumped. piston pumps are limited to special metering devices.

Centrifugal pumps are made with a variety of materials, and in many cases the impeller and casing may be covered with a corrosive- or abrasive-resistant naterial such as stainless steel, rubber, polypropylene, and stoneware. When. the pump is used with suspensions, the ports and spaces between the vanes must be large enough to eliminate the risk of blockage. This does not nean that the efficiency of the pump is necessarily reduced. Special pump designs may be sed to cvercome this problem and also provide subatmospheric pressure at the glands ard bearings to protect then from grit. Because high pressures are seldon required in the food industry, such designs present no penalty. Metal to-metal contact is avolded to reduce wear debris.

The mono pump uses a specially shaped helfcal metal worm, which rotates in a stator made of rubber or other similar materlal. The liquid is thus forced through the space between the stator and rotor. Stator replacement is required at regular intervals, but this factor is outweighed by the advantages of uniforn flow, quiet operation, and the abflity to pump against high pressures and to handle corrostue and gritty liquids.

\subsection{TRIBOLOGICAL LOSSES IN OTHER FOOD PROCESSIHG OPERATIONS}

\section{4 .1 Size Reduction Equipment}

Wear ts a signiflcant concern in some areas of the food industry, such as the cossette knives used for sugar beet size reduction. Sugar beets cone to the processor with a lot of grit and sand on them. cossette knives are used to cut the sugar beets into $1 / 8 \times 1 / 8 \times 2$ inch strips from which the sugar is 
leached. Wear debris is not a problem here because it is not contained in the sugar solution that is extracted. Instead, the debris is carried way with the other solid residues.

Large banks of Cossette knives must be reworked or replaced daily because of the dulling which results from abrasive wear from dirt on the beets. In a day's production, these knives will be used to cut up to 2000 tons of beets at a typical processing plant. In the United $5 t a t e s 72$ plants use cossette knives. The operation of 4 of these plants is sumbrized in Table 7.7 .

A typical cossette knife is $3 / 16 \times 4 \times 6$ inches or 4.5 cubic inches of high carbon steel, which weighs 1.27 pounds. This amounts to 10.6 pounds of knives per thousand tons of beet production. In 1974 there were 23.4 million tons of beets processed. Thus, for the entire U.S. sugar beet industry, about 124 tons of steet per year are consumed. This is equivalent to an indrect energy loss of $4.3 \times 10^{9} 8$ tu/year.

\section{4 .2 Mixers}

Telephone interviews with design engineers associated with the food industry indicated no major problems with wear in mixing equipment. Friction losses in bearings and gear-retucers were also found not to be significant.

\subsubsection{Other Size Reduction Equipment}

For other types of size reduction equipment, wear causes concern, but not nearly to the extent of the cossette knives. A typical puree operation involves cutting up clan fruits and vegetables for which a few grams of wear

TABLE 7.7. Cossette knife Replacement and Sugar Beet Production. 1983 Sumiary for Four Plants

\begin{tabular}{cccc} 
Plant & $\begin{array}{c}\text { Koives } \\
\text { Replaced }\end{array}$ & $\begin{array}{c}\text { Sugar Beet Pro } \\
\text { duction (ktons) }\end{array}$ & $\begin{array}{c}\text { Knives per kton } \\
\text { Production }\end{array}$ \\
\cline { 3 - 4 } 1 & $\frac{632}{2}$ & 220 & 2.873 \\
2 & 5540 & 352 & 15.739 \\
3 & 1536 & 286 & 5.371 \\
4 & 3460 & 374 & 9.251 \\
Ave. & 2792 & 308 & 8.309
\end{tabular}


debris are generated for every few million pounds of food processed. This debris is trapped in the food, but it is below the contamination levels permitted by the government regulations. Nonwear breakage or chipping of surfaces is considered a more dangerous problem because large debris results.

Rendering plants involve somewhat more wear because rendering involves size reduction of animal bones. Meat by-products can also create corrosive wear problems. Components specifically subject to this sort of damage include the exteriors and rotating parts of the size-reducing equipment.

Construction materials for size reduction equipment include mostly 304 stainless steel with some heat-treated 17-4 stainless steel where additional strength and better wear resistance is needed. Stellite 6 and Stellite 1 hard facings are used on areas needing high wear resistance.

\subsection{SUMMARY OF TRIBOLOGICAL ENERGY LOSSES IN THE FOOD INDUSTRY}

Analysis of the food processing industry identified size reduction and material conveyance as the two most significant tribological loss activities. The generic tribological mechanisms contributing to energy losses are identifjed in lable 7.8 for each of the operational activities for which losses were estimated. Direct and indirect losses are given in Tables 7.9 and 7.10 , respectively. Additional information on the principal energy form consumed by an operation, the energy loss rate, material type worn, and material wear rate is also provided in Tables 7.9 and 7.10 .

The direct losses estimated for conveyors was the largest tribological sink identified for food processing and was an order of magnitude greater than the sum of all indirect losses estimated. Conveying systems are chiefly powered by electricity as are size reduction operations. Direct losses in conveyors are attributed to abrasive and frictional tribological mechanisms.

Indirect losses resulted from the wearing away of material due to erosion, abrasion, and/or rolling friction. The principal material types being worn are low magnitude of direct losses for conveyors but are significant in specific food industry groups such as sugar beet refining. 
TABLE 7.8. Generic Tribological Loss Mechanisms in Food Processing

Operational Activity

Conveyance

Conveyors

Cranes

Roller Conveyors

Size Reduction

Cossette knives

(1) Erosion

(2) Abrasion

(3) Rolling Friction
Generic Tribological Mechanisms

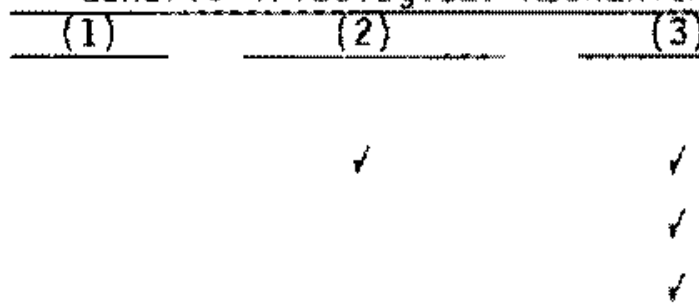

TABLE 7.9. Annual Direct Tribological Energy Loss in Food Processing

\begin{tabular}{|c|c|c|c|}
\hline $\begin{array}{l}\text { Operational } \\
\text { Activity }\end{array}$ & $\begin{array}{l}\text { Principal Energy } \\
\text { Form Consumed }\end{array}$ & $\begin{array}{c}\text { Energy Loss } \\
\text { Rate }\end{array}$ & $\begin{array}{l}\text { Total Energy } \\
\text { Loss }\left(10^{9} \text { Btu }\right)\end{array}$ \\
\hline Conveyors & Electricity & $5 \%$ of $70 a d$ & 520 \\
\hline
\end{tabular}

TABLE ? 10. Annual Indirect Tribological Energy lasses in Food Processing

$\frac{\text { Dperational }}{\text { Activity }}$
Roller Conveyors
Cranes

Cossette Knives

\begin{tabular}{l} 
Material \\
Type Norn \\
\hline Alloy steel \\
Steel \\
Alloy steel
\end{tabular}

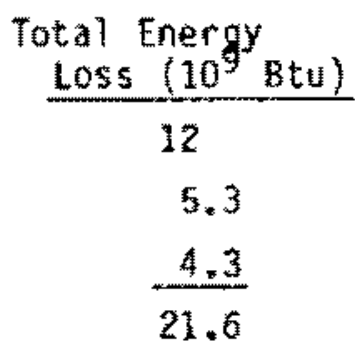

\subsection{REFERENCES}

Casper, M. E. 1977. Energy Saving Techniques for the Food Industry. Noyes Data Corporation, Park Ridge, New Jersey.

U.S. Bureau of Census. June 1983. 1982 Census of Manufactures, Fuels and Electric Energy Consumed. U.S. Department of Commerce, Bureau of the Census, Washington, 0... 


\section{DISTRIBUTION}

No. of

Copies

CFFSITE

12 T. Levinson

U.5. Gepartment of Energy

Forrestal Building CE-142

Washington, D.C. 20585

30 DoE Technica: Information center

A. Anderson

Multi-Arc Vacum systens inc.

26 East 5 th Avenue

St. Paul, Wh 55101

C. Bubertson

Borc-warner Corporation

$120 \mathrm{C}$ South wolf Road

Des Plaines, It 60018

6 S. Earber

Battelle-Columbus Laboratories

505 King Avenue

Collmbia, OH 43201-2693

A. Eecker

Alumina, chem, ceramics Diviston

Alcoa Research Laboratories

Alcoa Center, Ph 15069

P. N. Blumberg

Integral Technologies, Inc. 415 East plaza urive

Westmont, IL 60559

L. 3. Brontok $1 \mathrm{ch}$

Compu-Tec Engr. Inc.

300 Chesterfield Center, 205

Chestertield, 14063017

W. Rryzik

U.S. ARMY TACOM

AMSTAMRGR

Warren. MI 48090
No of

Copies

D. H. Buckley

NASA/Lewis Research Center

$23-2$

Cleveland, or 44135

R. F. Bunshah

Department of Materials science

Intyersity of Callifornia at

Los Angeles

6532 Boelter Hall

Los Angeles, CA 90024

1. A. Carpenter, JP.

Oak Ridge National Laboratory

po Box $x$, Bullding a 508

0ak Ridge, TN 37831

0. C. Classen

Caterpillar Tractor Co.

Mfg. Engr. Building $W$

600 west Washington street

East Peoria, IL 61630

F. d. Garignan

Advanced Mechanical

Technology Inc.

141 California street

Newton, MA 02158

0. L. Cocke

Texas An Iniversity

department of chemistry

College station. TX 7784a-3255

H. S. Cheng

Dept. of Mechanical Engineering

Center for Engineering

Tribology

Northwestern University

Evanston, IL 60201

G. W. Clark

Oak Ridge National Laboratory

P0 Box $X$, Building 4508

Dak Ridge, TN 37831 
No of

Copies

Q. Chang

29615 Lincoln Road

Bay village, OH 44140

M. U. Cronin

Mechanical Technology, Inc.

968 Albany-Shaker Road

Lathan, Ny 12110

J. L. Duda

pennsylvania state lniversity

133 Fenske Laboratory

liniverstity Park, Ph 16802

S. K. Das

Materials taboratory

Allied Corporation

P.0. Box 1021 年

Morristown, Nu 07960

U. F. Dill

Mechanical Technology inc.

968 Albany-shaker Road

Latham, N 12110

p. L. nasilueira

Eutectic corp.

4040172 nd street

Flushing, NY 11358

J. J. Eberharat

U.S. Department of Energy

Forrestal Building

Mat 1 Stop 68025

Washington, $0 . \mathrm{C}$. 20585

C. A. Ebel

High Performance Ceramics

Norton Company

1 New Bond street

Worcester, MA 01606

6 R. erickson

Battelle-Columbus Laboratories 505 king Avenue

Columbus, OH 43201-2693
No of

Capies

1. 1.* Fehresbacher

200\%. Huntwood Drive

Huntington woods

Gamurills, MD 21054

0. B. Flom

General Electric Company

Corporate $\mathrm{R}: \mathrm{B}, 4 \mathrm{~B} 4, k_{-1}$

P. O. Box 8

Schenectady, NY 12301

T. تischer

Exwn Research

clinton Township noute 22 East

Annandale, N 08801

P. arayson

agle Picher Industries, Inc.

P. D. Box 1090

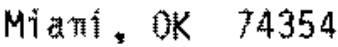

ป. Graham

Deere and Company

Technical Center

3300 River Drive

Moline, IL 61265

S. Goguen

11. S. Department of Energy, CE 131

Majistop 5E 043

Forrestal Building

1000 Independence Ave., SW

Washington, D.C. 20585

R. M* Gresham

EfN Lubricants, Inc.

P.0. Box 2200, Hitghay 52 N.W.

West Lafayette, IN 47906

6 T. Gruber

Battelle-Columbus Ladoratories

505 King Avenue

Columbus, oH 43201-2693 
No of

copies

3. Horwath

Borguwarner Corporation

Ingersoll Research Center

1200 5. Wolf Road

Des Plaines, It 60018

S. 11. Hsu

Room A257, Building 223

Inorganic Materials division

Mational bureau of standards

Gathersburs. 10 zoges

N. S. hakin (RD3B)

Detrott Diesel Allison Division

$368 \mathrm{co} 0$ Ecorse Rodd

Rumults, MI 48174

C. R. Houska

Dept. of Materials Engineering Vircinia Polytechnic Institute Blacksburg, VA 24061

R. A. Harmon

25 Schalren Drive

Latham, Ny 12110

$J$. K. Hirvonen

Spi re corporation

Patriots Park

Bedford, WA 07130

10 H. Kaminsky

Argone National Laboratory

9700 south Cass

Argonne, IL 60439

E. E. Klaus

Dept. of Chemical Engineering

Pennsylvania state University

University Park, PA 16802

R. Krutenat, 102/0217

Exxon Research and

Engineering Co.

Florham Park, Nal 07932
No of

Copies

S. Khanna

Solid State Science Research Group

Jet Propulsion Laboratory

4800 0ak Grove Drive

us $122-123$

Pysadena, CA 91109

R. Ludema

University of Michigan

Dept. of Mechantcal Engineering

20246 . a brown

Ann Arbor, Ml 48109-2125

Librarian

Deere and Company

Technical center

3300 River Drive

Holine, IL 61265-1792

F. F. Ling

Mechanfcal Engineering

Jonsson Engineering Center

Rensselaer Polytechnic institute.

Troy, NY 12181

H. Lexhac

DHE Ine.

6849 old Doninion Drive

Melean, 垶 22101

H. E. Mccormick

Director of Engineering

Ransey piston Ring Dlvision

TRW Automotive Products, inc.

1233 Manchester Road

Manchester, Mo 63011

C. Mecklenburg

AFWAL/MLBT

Wright Patterson AFB

Dayton, oH 45433-6533

3. MeCOOl

SKF Industries

$1100 \mathrm{First}$ Avenue

King of Prassia, PA 19406 
No of

Coples

67. Merriman Bateqlle-columbus Laboratories 505 king Avenue columbus, of $43201-2693$

R. W. Meyerhoff Union Carbide Corporation Coatings Service 1500 Polco Street Indianapolis: iN 46224

J. R. Mullaly

Pratt 2 Whitney Alroraft

P.0. Box 2591

MS $707-28$

west Palm Beach, FL 33402

P. Madden

$5 k F$ Industries

1100 First Avenue

king of Prussiz, PA 19506

M. p. Peterson

Wear sciences, Inc. 925 Mallard circle

Arnold, 21012

0. pinkus

Mechanical Technology Inc. 968 Albany-shaker Road

Latham, NY 12110

1.F. I. Quinn

Tribology and Rheology Laboratory

School of Mechanical

Englneering

Georgia Institute of Technology

Atlanta, CA 30332

R. C. Rosenberg

General Motors Research Laboratory

Fluid Machanics Department

Warren, M* 48090
No of

copies

0. A. Rigney

The onto state Iniversity

Dept. of Metallurgical

Engineering

$141 \%$ Fontana Laboratories

116 West 19 th Avenue

columbus, on 43210-1179

A. W. Ruff

Nat onal Bureau of Standards

Metallurgy Division

Roon Bz66-Materials Building

Gatrhersburg, Ma 2089

W. D. Sproul

Borswarner Corporation

l200 Sotth Wolf Road

Des Platnes, Il. 60018

P. Sutor

Midwest Research institute

425 volker Boulevard

Kansas City, M0 64110

L. B. Sibley

Tribology Consultants, Ine,

504 Foxwood lane

Paoli. PA 19301

A. C. Schaffhauser

oak Ridge National Laboratory

P.C. Box $X$

oak Ridge, TN 37831

1. L. Singer

Naval Research Laboratory

Code 6170

washington, D.C. 20375

G. L. Starr, Manager

Metalurgical Engineering

Cumins Engine Technical Center

Bo: 3005

Columbus, In 47202-3005 
No of

copies

R. Slone 50165

Cumrins Engine Technical Center

Box 3305

Columbus, IN 47202-3005

T. C. Spalvins

NASA / Lewis Research Center

MS 23-2

Cleveland, $\mathrm{OH} \quad 44135$

M. Shaw

Arizona State University

ECG 247, Mechanical Engineering

Tempe, AZ 85287

P. Swanson

John Deere Company

Technical Center

3300 River Drive

Moline, IL 61265

L. D. Wedeven

SKF Industries, Inc.

1100 First Avenue

King of Prussia, PA 19406

R. Ted Wimber

Deere and Company

Technical Center

3300 River Orive

Moline, IL 61265-2792

D. F. Wilcock, President

Tribolock, Inc.

1949 Hexham Road

Schenectady, NY 12309

W. 0 . Winer

Tribology and Rheology Laboratory

School of Mechanical

Engineering

Georgia Institute of Technology

Atlanta, GA 30332
No of

Copies

D. Kuhlman-Wilsdorf

University of Virginia

Physics Department

McCormick Road

Charlottesville, VA 22901

W. H. Winnard

Battelle Memorial Institute

2030 M. Street NW

Washington, D.C. 20036

C. S. Yust

Metals and Ceramics Division

Oak Ridge National Laboratory

P.0. Box $X$

Oak Ridge, TN 37831

T. M. Yonushonis

Cummins Engine

Mail Code 50183, Box 3005

Columbus, IN 47202-3005

M. Zlotnick

141 East 88th Street

New York, NY 10028

C. A. Zanis

Department of the Navy

Naval Sea Systems Command

Research and Development office

Washington, D.C. 20362

FOREIGN COUNTRIES

Dr. Jochen P. Biersack

Hahn-Meitner-Inst itut

Glienicker Strabe 100

1000 Berlin 39

West Germany

Dr. Erich Bergmann

Balzers Aktiengesellschaft

FL-9496 Balzers

Furstentum, Liechtenstein 
Nio of

Copies

Professor Dr. H. Czichos

Federal Institute for Materials Research and Testing

unter den Eichan 8 ?

0-1000 Berlin 45

West Germany

Dr. Geoff Dearnaley

Nuclear Physics Division

Building 18

AERE harwell

Didcot, 0xfordshire

United kinguon ox 11 ORA

Dr. Hans $F$. Hintermann

Laboratoine Suisse de

Recherches Horlogeves

CH-zooo Neuchatel

5whtzerland

Dr. Richard Horton, Manager

Energy Conservation Technology centre

Engineering Sciences Division

B151 Harwell Laboratory

Oxfordshire of 11 ORA

England

Dr. Boris Navinsex

Jozef Stafan Institute

61001 Ljubljana

Jamova 39

Yugos lavia

Prof. Or. ir. a. Roos

Ratholieke Universiteit Leuven

Departnent Metall kunde de Croylaan 2

$0-3030$ Leuven (Heverlee)

Belgiun

Dr. S. Veprek

Anorganisch-Chemisches

Institut der Universitat Zurich

Winterthurerstrasse 190

8057 zurich

switzerland
No. of

Coples

ONSITE

DOE Richland Operations office

H. E. Ransom

41 Pactic Northwest Laboratory

D. . Brenchley

D. R. Brown (6)

G. 1. Hane (6)

R. A. Hutchingen (6)

C. H. Imhoft (12)

D. . vilick

J. Russell

M. T. Thomas

Publishing coordination MH (2)

Technical information (5) 